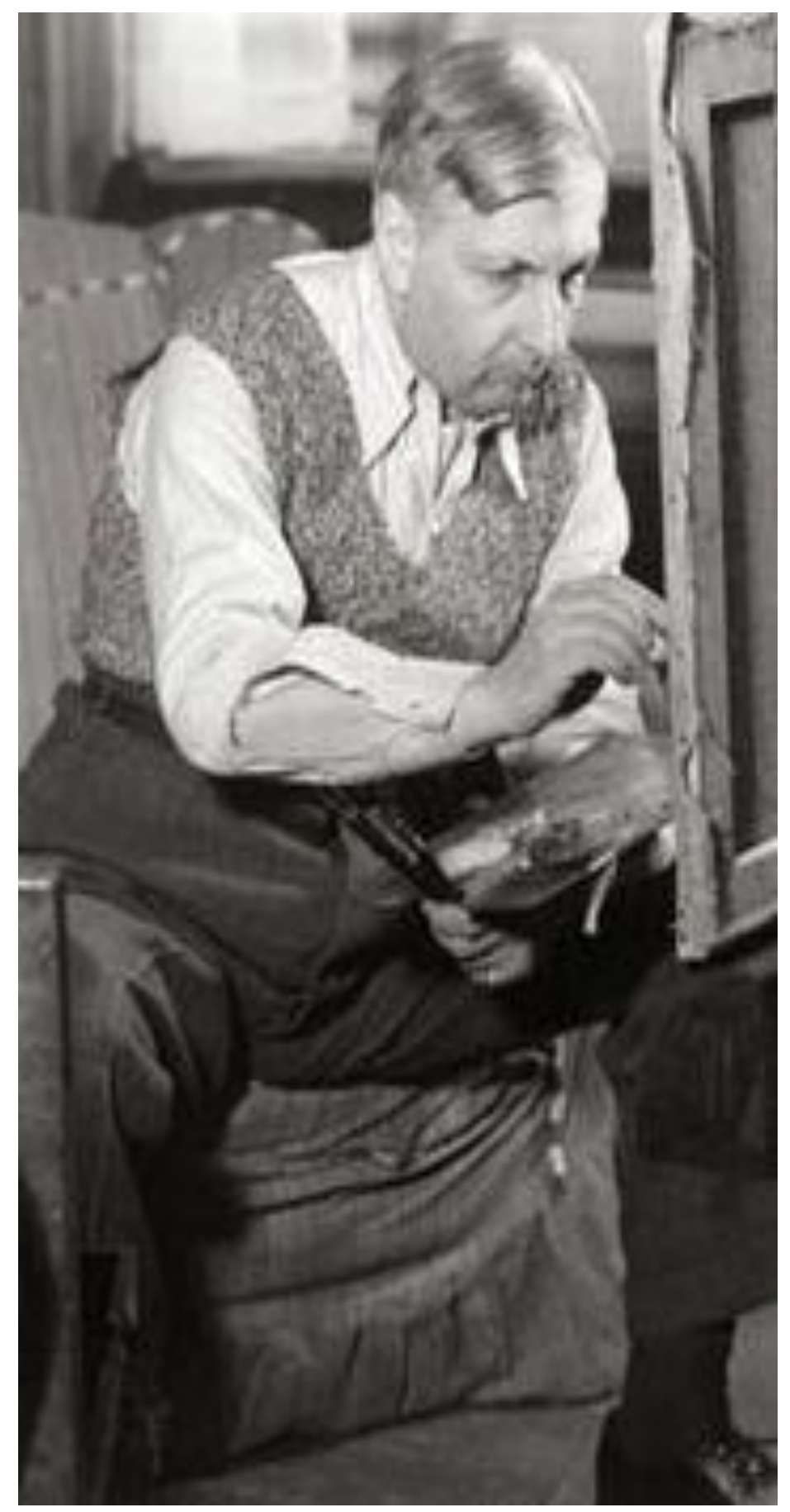

\title{
Melancolia e Questões Estéticas Giorgio De Chirico
}




\title{
Universidade de São Paulo \\ Programa de Pós-Graduação em Artes Visuais
}

\section{MELANCOLIA E QUESTÕES ESTÉTICAS Giorgio De Chirico}

\author{
Paulo Roberto Amaral Barbosa
}

Escola de Comunicações e Artes

ECA USP

São Paulo

2011 


\section{MELANCOLIA E QUESTÕES ESTÉTICAS Giorgio De Chirico}

Paulo Roberto Amaral Barbosa

Tese de doutorado a ser apresentada ao Programa de Artes Visuais da Escola de Comunicações e Artes da Universidade de São Paulo - ECA-USP, na área de concentração Teoria, Ensino e Aprendizagem da Arte, na Linha de Pesquisa História, Crítica e Teoria da Arte, sob a orientação da Profa. Dra. Elza Maria Ajzenberg.

São Paulo, 2011

ECA USP 


\section{FOLHA DE APROVAÇÃ̃o}

Autor: Paulo Roberto Amaral Barbosa

Título: Melancolia e Questões Estéticas - Giorgio De Chirico

Tese defendida e aprovada em: pela banca examinadora: 
Para Emília e Zeni que, incondicionalmente, estão comigo sempre. Aos meus irmãos 


\section{AGRADECIMENTOS}

Quero agradecer com especial carinho à Profa. Lisbeth, ao Prof. Percival, ao Prof. Kabengele, ao Prof. Frayze-Pereira, e ao Prof. Edson Leite que muito contribuíram para o desenvolvimento desta tese.

Com grande entusiasmo agradeço também: Ana Farinha, Beatriz Cavalcanti, Claudia Assir, Regina Pavão, Elaine Maziero, Roseli, Cida, Renata, Rejane, Ariane, Márcia, Cris Cabral, Gabriel Borba e Sara.

Ao meu cunhado Valter, aos meus sobrinhos Tatiana, Daniel e Denise pelas nossas conversas durante o desenrolar deste trabalho.

À Lígia e Eliany pela preciosa assistência na tradução de textos contributivos para a tese.

À Aleca por todos os motivos.

À Profa. Elza pela tenacidade e esmero com que me orientou nesta viagem poética. 


\section{RESUMO}

A reflexão sobre a melancolia, na produção estética de Giorgio De Chirico, compõe o arcabouço da presente pesquisa. Neste estudo, são considerados sentimentos e ressentimentos que permeiam aspectos biográficos e estéticos ligados direta e/ou indiretamente às questões da melancolia na obra do artista Giorgio De Chirico. A constituição melancólica de sua produção seria sustentada pelas referências do artista? Isto é, a reconhecida influência de filósofos como, Nietzsche e Schopenhauer e de artistas como Arnold Böcklin e Max Klinger forneceria o embasamento à postura melancólica de De Chirico? O contexto vivido na Europa, no século XX (cercado por duas Guerras Mundiais) contribuiu para a adoção desta condição? As circunstâncias biográficas direcionariam o artista para a expressão da melancolia em seus trabalhos? E, por fim, De Chirico utilizaria o que poderia se chamar de uma "estética da melancolia" como um dos eixos de sua reflexão poética? A elucidação dessas perguntas pode residir nas fontes históricas que unem melancolia e arte desde os escritos dos filósofos gregos, passando pelas questões do Renascimento e chegando ao ideário moderno - do qual De Chirico é fruto. 


\section{ABSTRACT}

The melancholy reflection on the aesthetic production of Giorgio De Chirico makes up the framework of this research. In this study, the

feelings and resentments that permeate biographical aspects and aesthetic and linked directly or indirectly with issues of melancholy in the work of artist Giorgio De Chirico, are considered. Would the melancholy constitution of his production be sustained by the references of the artist? That is, would the recognized influence of philosophers like Nietzsche and Schopenhauer and artists such as Arnold Böcklin and Max Klinger provide the basis for de Chirico's melancholy posture? Would the context experienced in Europe in the twentieth century (surrounded by two world wars) contribute to the adoption of this condition? Would the biographical circumstances steer the artist to the expression of melancholy in his works? Finally, would De Chirico utilize what might be called an "aesthetics of melancholy" as one of the pillars of his poetic reflection? The elucidation of these questions may lie in the historical sources that combine art and melancholy from the writings of the Greek philosophers, through questions of the Renaissance and coming to modern ideas - of which De Chirico is the fruit. 


\section{PALAVRAS-CHAVE}

Melancolia; Giorgio De Chirico; Arte Moderna

KEY WORDS

Melancholy; Giorgio De Chirico, Modern Art 


\section{SUMÁRIO}

INTRODUÇÃ

ESTÉTICA DA MELANCOLIA.................................................20

Os Humores e a Bílis Negra.....................................................21

O Anjo de Dürer e os Herdeiros de Saturno.......................30

"A Doce Melancolia" - Séculos XVIII e XIX....................44

LEITURAS DA MODERNIDADE......................................62

O Estado Melancólico........................................................63

A "Revelação" e A Guerra.....................................................72

O Retorno ao Passado e/ou Rumo ao Futuro.....................82

DE CHIRICO E A "SOLIDÃO DOS SIGNOS".........................91

“O Poder da Ruína".......................................................................92

As Metáforas Plásticas....................................................102

A Atmosfera (Luz e Sombra)...............................................134

CONSIDERAÇÕES FINAIS............................................139

REFERÊNCIAS BIBLIOGRÁFICAS...................................145

ANEXO: BIOGRAFIA DE GIORGIO DE CHIRICO...........153 
Por que todos os homens considerados excepcionais (perittói), no que concerne à filosofia, à política, à poesia ou às artes, são manifestamente melancólicos (melancholikói) e alguns a ponto de serem tomados por males da bílis negra (melaínes cholés)?

Aristóteles, Problèmes. Tome III, Problema XXX, 953 a 10. Sections XXVII à XXXVIII et index. Texte et traduit par Pierre Louis. Paris, Les Belles Lettres, 1994. 


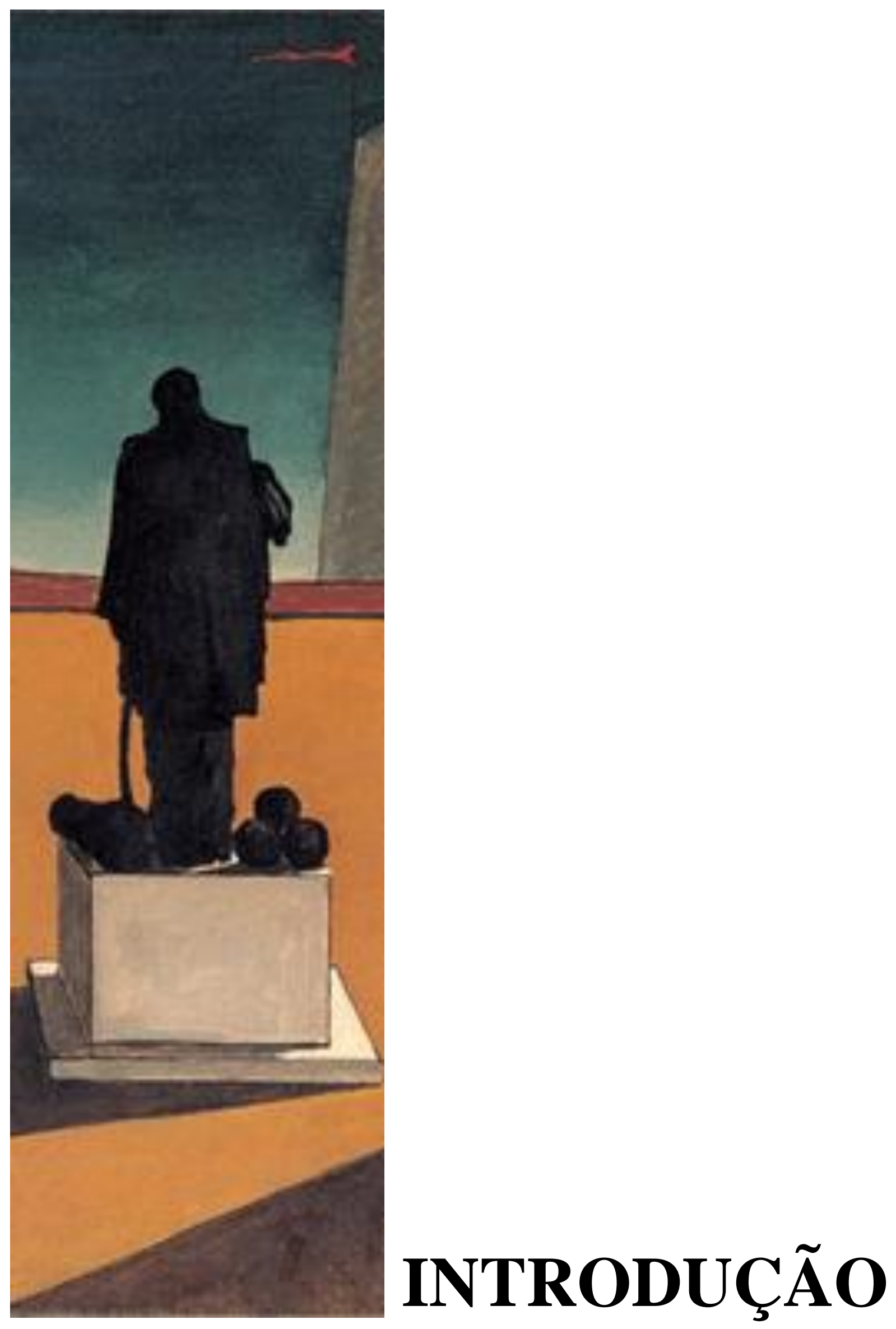


Inerente à condição humana, a expressão da melancolia se faz presente em muitos momentos da História da Arte. Manifestações artísticas remotas, clássicas ou mais recentes, têm buscado expressar esse "mal-estar". O termo

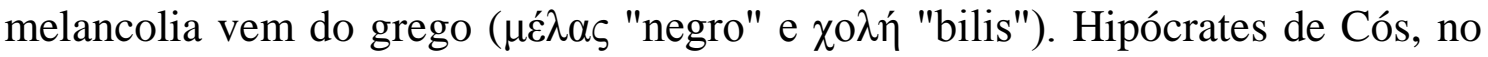
século V a.C, elabora a teoria dos quatro humores corporais (sangue, fleugma ou pituíta, bílis amarela e bílis negra). Para o filósofo, esses humores são responsáveis pelo equilíbrio ou desequilíbrio do indivíduo, indicando a saúde (eucrasia), a enfermidade e a dor (discrasia). ${ }^{1}$ Hipócrates sugere que a influência de Saturno leva o baço a secretar mais bílis negra, escurecendo-o, alterando o humor do indivíduo, levando-o ao estado de melancolia. ${ }^{2}$ A conexão estreita entre melancolia (Saturno), a disposição sanguínea (Júpiter), o sentimento colérico (Marte) e o fleumático (Lua), parece ter sido estabelecida, pela primeira vez, por escritores árabes, no século IX. Al-Kindt, por exemplo, distingue quatro partes do círculo do dia segundo os quatro humores ou temperamentos. ${ }^{3}$

A tradição dos estudos sobre a melancolia tem como marco o Problema $X X X, 1$ de Aristóteles (no qual os gênios teriam uma pré-disposição ao sentimento). Passa pelas ideias de Galeno (nas quais, configura-se em doença do corpo e da alma) e recebe variadas interpretações de diversos outros pensadores da Antiguidade. Torna-se uma questão discutida, particularmente nos períodos de crise da cultura ocidental, como por exemplo, durante a Idade Média,

\footnotetext{
${ }^{1}$ SCLIAR, Moacyr. Saturno nos Trópicos: A Melancolia Europeia Chega ao Brasil. São Paulo: Companhia das Letras, 2003, p. 32.

2 (...) cada humor tem no corpo sua fonte específica: a cabeça é a fonte do flegma, o coração a do sangue, o baço a da água e o "pequeno sítio" sobre o fígado (...) é a da bile. PIGEAU, Jackie. Metáfora e Melancolia: ensaios médico-filosóficos. Rio de Janeiro: PUC Rio/Contraponto, 2009 , p. 56.

${ }^{3}$ Os nascidos no primeiro quadrante, desde o ascendente até o meio-céu, são sanguíneos; os do segundo são coléricos; os do terceiro, melancólicos e os do quarto quadrante são os fleumáticos. (Alvarenga, Aline. "Melancolia, esperança e genialidade ou melancolia generosa". www.constelar.com.br. Acesso em 24 de julho de 2007.
} 
transformando-se em acedia, uma afeição da alma, uma disposição do espírito e do corpo que atinge principalmente os monges, conduzindo à inatividade e à perda da fé na salvação. No Renascimento, a melancolia é considerada como uma doença "bem-vinda", uma experiência que enriquece a alma e pode despertar a imaginação criativa. No Humanismo, a vida contemplativa somente pode existir a partir do princípio melancólico. Já no Romantismo, para viver a melancolia, descrita por Goethe, é necessário se acompanhar de paz, quietude, silêncio e ócio $^{4}$, considera-se, então, que essas são características da melancolia produtiva e companheira de todo o indivíduo que atinge elevado grau de intelectualidade retornando à escola peripatética. ${ }^{5}$

No âmbito da estética, as representações em torno da melancolia podem ser explícitas, revelando sofrimento físico (feridas abertas, corpos dilacerados, moléstias, entre outros flagelos). Podem, também, desvelar os suplícios morais, psicológicos e políticos. Por toda a história, os artistas - por meio de seus trabalhos - expõem sentimentos e ressentimentos, registros de suas memórias, ou ainda o ar resignado frente ao irreversível da mortalidade: as ambiguidades do ser humano são evidenciadas, demonstrando sua frágil condição. ${ }^{6}$

Na História da Arte e da Literatura, alguns artistas e escritores abordam questões estéticas, relacionadas à melancolia, em suas produções. Imagens literárias que expressam tal sentimento surgem nas obras renascentistas, como por exemplo, nos escritos de Cervantes ou Shakespeare. O artista renascentista Albert Dürer, em sua gravura Melancolia I (1514), evoca a "melancolia imaginativa" - própria dos artistas, arquitetos e artesãos - em oposição à “melancolia racional”, típica dos médicos, cientistas e políticos e, ainda, contra a "melancolia mental", aspecto da personalidade de estudiosos de teologia e

\footnotetext{
${ }_{5}^{4}$ SCLIAR, Moacyr. Saturno nos Trópicos... op. cit., p. 53.

${ }^{5}$ Idem. Aqui se apresenta o princípio do Problema XXX de Aristóteles que levanta a questão de que todo o "homem genial" teria uma natureza melancólica.

${ }^{6}$ ARGAN, Giulio Carlo. Arte Moderna. São Paulo: Companhia das Letras, 1992, p. 50 e seguintes.
} 
segredos divinos. ${ }^{7}$ Dos quatro humores, a melancolia é o que se torna alegoria ${ }^{8} \cdot$, ou seja, transforma-se em personagem que compõe a ação pictórica.

Jean-Antoine Watteau, no século XVIII, surge para todos os seus biógrafos como um espírito melancólico. A interpretação de sua produção como frívola é algo superficial que não leva em consideração seu temperamento instável, cerebral e meditativo. ${ }^{9}$ A “doce melancolia", preconizada por Watteau, torna-se um conceito discutido por pensadores franceses, tal como Diderot, e encontra na obra de Joseph-Marie Vien sua expressão: a mulher serena e meditativa. Contudo, no Iluminismo, a atração pelo temperamento melancólico é considerada aspecto negativo. Para o "homem racional" a busca da felicidade não passa por tal sentimento, pelo contrário, a melancolia é algo que precisa ser domado.

É através do Romantismo, no século XIX, que a melancolia retorna às discussões estéticas. O interesse do homem pela natureza, pelo exótico e pelo selvagem revigora a tradição aristotélica. Nessa perspectiva, as poéticas de Arnold Böcklin e Max Klinger unem elementos míticos à beleza e à tristeza. $\mathrm{O}$ sentir-se melancólico torna-se atributo para a aquisição de conhecimento, isto porque a autorreflexão proporcionada pelo sentimento levaria às novas percepções do mundo. As fontes românticas inspiram diretamente os primeiros exercícios estéticos de Giorgio De Chirico ${ }^{10}$, em meados do século XX.

\footnotetext{
${ }^{7}$ BERLINCK, Luciana Chauí. Melancolia - Rastros de Dor e Perda. São Paulo: Humanitas, 2008, p. 29 e seguintes.

${ }^{8}$ Alegoria: s.f. Expressão de uma ideia através de uma imagem, uma tela, um ser vivo, entre outros elementos; obra literária ou artística que utiliza esta forma de expressão: os autos das barcas de Gil Vicente são alegorias. Na estética ocidental, a alegoria é retórica metafórica continuada com significado diverso daquele diretamente enunciado. Na representação alegórica da melancolia, a figura da mulher reclinada e pensativa torna-se a personagem que corporifica a melancolia em muitas telas. A "posição do pensador" também é colocada como uma alegoria da melancolia. TAROBINSKI, Jean. "L'Encre de la Mélancolie". In: GALERIES NATIONALES DU GRAND PALAIS, Mélancolie: Genie et Folie en Occident. Paris: Gallimard, 2005, p. 24.

${ }^{9}$ FAROULT, Guilherme. "La Douce Mélancolie - Selon Watteau et Diderot - Représentations Mélancoliques dans les Arts en France au XVIII Siècle". In: GALERIES NATIONALES DU GRAND PALAIS, Mélancolie: Genie et Folie en Occident... op. cit., p. 274 e seguintes.

${ }^{10}$ Giorgio De Chirico estuda em Atenas. Segue para Munique em 1905, tendo recebido nessa época influências do romantismo de Böcklin, do simbolismo de Klinger e da filosofia de Nietzsche e Schopenhauer. De Chirico alcança grande projeção dentro das correntes artísticas vigentes, contribuindo, decisivamente, para o Surrealismo, proposto por Breton, em 1924. Mais
} 
De Chirico assimila o sentimento melancólico como elemento constitutivo de sua produção artística. Na Pintura Metafísica, o artista desempenha a função de um autor que ao narrar uma trama enigmática, desvela a sátira embutida no "desejo da cultura ocidental de tudo saber e conhecer". ${ }^{11} \mathrm{Em}$ outros trabalhos, a melancolia é representada pela figura de Ariadne ou pelas luzes e sombras que cercam seus cenários entre ruínas e máquinas, entre símbolos da antiguidade e da modernidade. A reflexão sobre a melancolia na produção estética de Giorgio De Chirico compõe o arcabouço da presente pesquisa.

As "memórias vivas" do pintor são responsáveis pela produção de uma poética instigante que leva o espectador à contemplação, à reflexão e a um universo de múltiplas citações. As metáforas, criadas pelo artista, carregam, invariavelmente, uma atmosfera melancólica escondida atrás dos objetos heterogêneos sem uma aparente lógica. Em suas obras repletas de citações destacam-se: praças desertas, arcadas irreais; pesadas torres; dominantes chaminés industriais e a presença da máquina, algumas vezes representada pelo trem. As cenas retratadas são acrescidas por sombras projetadas e manequins nus ou vestidos em estilo clássico (desprovidos de fisionomia e com expressão enigmática), provocando a estranheza do elemento humano à cidade. Em outras fases surgem cavalos, gladiadores, nuvens e as naturezas-mortas completam a produção plástica de De Chirico.

Dentro desse quadro repleto de metáforas é possível levantar os seguintes questionamentos: o sentimento melancólico, na produção de Giorgio De Chirico, parte de sua vivência (experiências e estado de saúde)? Seria derivado de seu contexto (a inesperada perda do pai, período entre guerras, da sua identidade nacional ambígua, entre outros fatores)? Da influência do repertório romântico de Böcklin e de Klinger e da filosofia de Nietzsche e Schopenhauer (centrada na questão existencial)? Ou, ainda, derivaria do seu repertório consubstanciado por Roberto Amaral. Giorgio De Chirico no Acervo MAC USP. São Paulo: ECA USP, 2006 (Dissertação de Mestrado), p. 32 e seguintes.

${ }^{11}$ Idem. 
metáforas e pelo forte impacto da arquitetura em seus trabalhos? Estes são os principais eixos de reflexão do presente estudo. Resume-se, daí, que o problema central deste trabalho reside em saber: de que forma De Chirico insere a questão da melancolia em sua produção? Como identificá-la?

Na busca de possíveis respostas, é importante lembrar que a trajetória artística de Giorgio De Chirico é marcada por diversas fases e séries. Nos Enigmas $^{12}$, por exemplo, a herança greco-romana funde-se com o contexto urbano-industrial e nessa composição o humano é, aparentemente, destituído de significado, ou levado a ser figura secundária, perante a arquitetura. Os seres antropomórficos existentes nesse mundo inconsciente são estátuas e manequins elementos também privados de humanidade. Então, como a melancolia - um sentimento tão humano está inserido nessas metáforas? É possível que a resposta esteja no conjunto de representações que assume uma impressão cenográfica de dramaticidade, na qual a sobreposição dos elementos enigmáticos, somados à iluminação, provoca inquietações ao espectador e o remete às sensações despertadas pela melancolia (como, por exemplo, solidão, silêncio, contemplação, introspecção e tristeza).

$\mathrm{O}$ recorte desta pesquisa dirige atenções para as obras de Giorgio De Chirico - muitas com denominações expressas, evocando a melancolia, como por exemplo, A Melancolia de uma Bela Tarde (1913), Melancolia e Mistério na Rua (1914), Melancolia de Um Belo Dia (1916), entre outras. Acrescentem-se, ainda, obras, tal como o Autorretrato (1911) que não dispõe do termo "melancolia" no título, mas evoca o estado melancólico em sua produção. Nestas obras, existe um vínculo entre o passado e as intervenções do mundo moderno. As composições são simbólicas e convidam o espectador à contemplação e aos mistérios da vida.

A condução da pesquisa orienta-se no método histórico crítico, proposto por Giulio Carlo Argan, utilizando a análise estética na obra de Giorgio De

\footnotetext{
${ }^{12}$ A série de Enigmas de De Chirico data de 1909 e prossegue pelos primeiros anos da década seguinte. É o marco da pintura metafísica do pintor. Porém, o termo somente surge em 1915, quando este encontra Carlo Carrá (1881-1966) no hospital militar de Ferrara, em decorrência da I Guerra Mundial. Idem, p. 46.
} 
Chirico. As estratégias metodológicas voltam-se aos contatos com fontes primárias, tais como documentos, obras de arte, registros fotográficos e fílmicos, além de estreitar o relacionamento com acervos de instituições artístico-culturais nacionais e internacionais, especialmente na Itália, nos Estados Unidos, na Alemanha, na França e na Espanha (lugares que concentram grande parte da produção de Giorgio De Chirico). Nesse sentido, acervos e exposições foram visitados, em Pádua, Veneza, Paris, Madri, Valencia, Munique, Londres e Nova York e importante material bibliográfico foi coletado, tal como o livro Mélancolie: Genie et Folie en Occident, organizado pelo Grand Palais, com pesquisadores que exploram a melancolia e a sua influência nas grandes produções da História da Arte.

O exercício de investigação remete à organização de um levantamento bibliográfico e a uma leitura sistemática sobre o tema Melancolia. Autores como Aristóteles, Agrippa, Marsílio Ficino, Robert Burton, entre outros são evocados para a compreensão do histórico do tema. Todavia, sublinha-se que o interesse do estudo está focado na origem da relação existente entre estética e melancolia. Essa vertente é apoiada por autores, tais como: Paolo Baldacci (especialista em De Chirico), com o livro De Chirico - The Metaphysical Period; Marie-Claude Lambotte, autora do estudo Estética da Melancolia; Moacyr Scliar através dos seus escritos em Saturno nos Trópicos; Julia Kristeva com Sol Negro e Jackie Pigeau com a publicação Metáfora e Melancolia.

Desse modo, o trabalho que ora se apresenta divide-se em:

Na primeira parte, Estética da Melancolia, evoca-se a história do tema, iniciando essa trajetória a partir da teoria dos quatro humores e a ação da bílis negra no organismo e no temperamento dos homens. Em seguida, parte-se para a análise do tema melancolia nas artes a partir dos exemplos de artistas que refletem sobre este sentimento em suas produções. Na sequência, tem-se a afirmação do sentimento como distinção dos pensadores, filósofos e artistas à luz 
das noções da "doce melancolia”, nos séculos XVIII, XIX e seus desdobramentos no Romantismo.

Na segunda parte, Leituras da Modernidade, debruça-se sobre o estudo da melancolia vista pelos elementos que compõem o século XX e a biografia de Giorgio De Chirico, entre esses: a "revelação" de De Chirico, vivenciada na Piazza Santa Croce (Florença/Itália), os efeitos da guerra em larga escala, as decorrências da Revolução Industrial e a produção artística que vê a modernidade com sentimentos dúbios - entre o retorno ao passado e a iminência do futuro. Exploram-se esses aspectos a partir do percurso estético de Giorgio De Chirico, suas leituras e estudos sobre a filosofia de Nietzsche e Schopenhauer, seu estado melancólico e os desdobramentos desses fatores sobre sua produção até o seu relacionamento com o grupo surrealista.

Já na terceira parte, De Chirico e a "Solidão dos Signos", o estudo dedicase à produção artística de Giorgio De Chirico e aos indícios que trazem o sentimento melancólico ao seu repertório criativo. Nessa abordagem as referências filosóficas, literárias, estéticas e biográficas do artista são as principais fontes. As ideias, o discurso e as questões estéticas que envolvem a melancolia imersa na poética de Giorgio De Chirico são elementos perscrutados a partir da análise de suas obras, particularmente, as da fase metafísica.

Formulam-se, ainda, novos caminhos para conectar o contexto histórico ao momento vivido pelo artista em questão. Sugere-se que o sentido da melancolia encontrada na trajetória de Giorgio De Chirico é resultante de uma estética construída desde Aristóteles, passando pelas leituras medievais, renascentistas e românticas. Na poética de De Chirico instaura-se uma concepção relacionada aos signos herméticos de uma tradição que nasce na Antiguidade, mas que no início do século XX torna-se a consciência do homem moderno. 


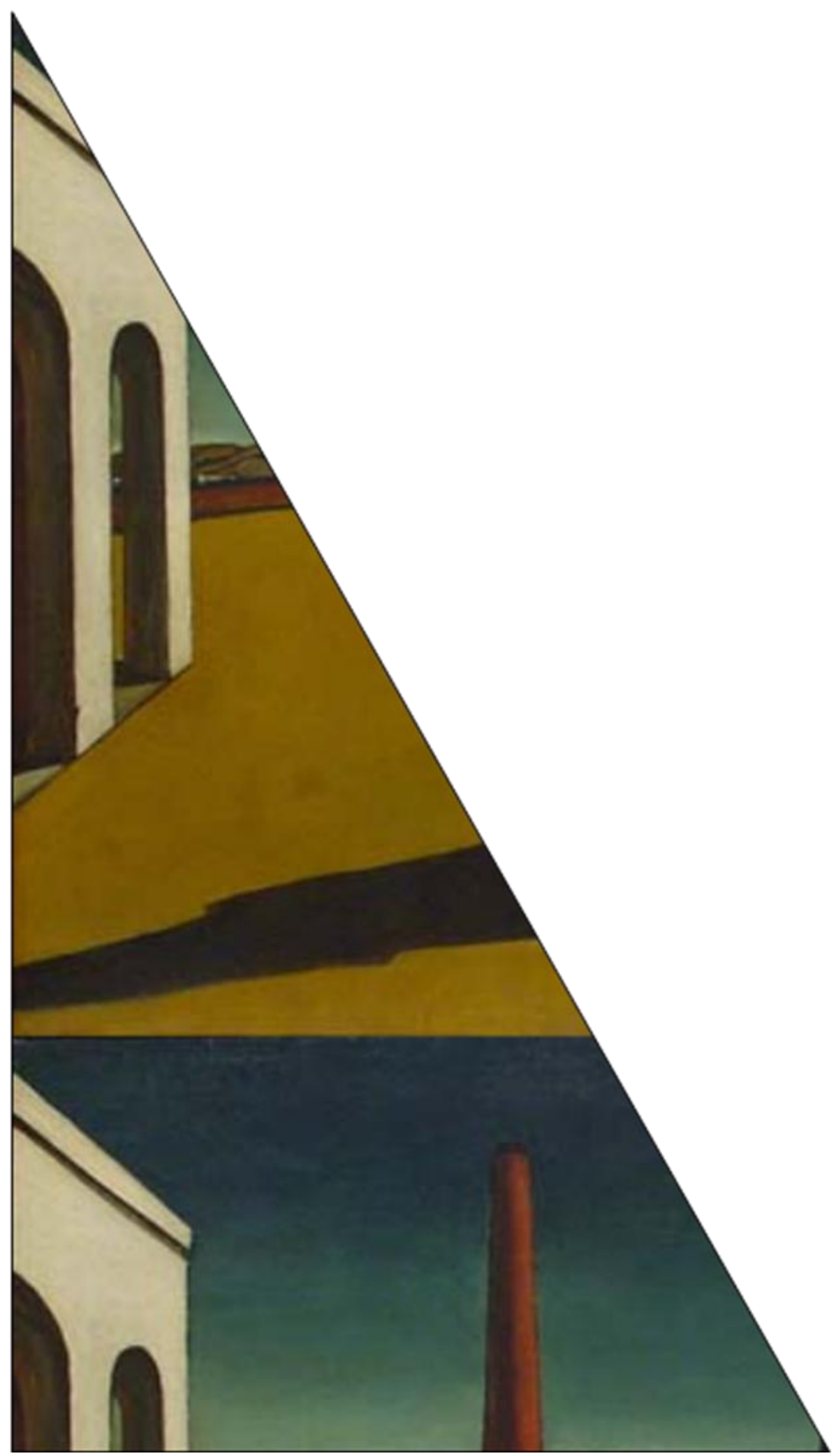

\section{ESTÉTICA DA MELANCOLIA}




\section{Os Humores e a Bílis Negra.}

A tradução grega para melancolia é melaina cholè, ou ainda, bílis negra - do mesmo modo que atrabílis é seu similar latino. A bílis negra, por sua vez, é um dos quatro humores, ou fluídos, estabelecidos pela tradição médica que tem início no século V a.C., na Grécia, com Hipócrates e a escola de Cós. Os conhecimentos sobre os humores são reunidos durante o século III a.C., na Alexandria de Ptolomeu e retomados no século I d.C., em Roma, pelo físico Galeno, que faz a síntese das ideias de Hipócrates, de Platão e de Aristóteles, assim como, de outros pensadores antigos. ${ }^{1}$

Para esses pensadores, os humores são as substâncias que explicam a constituição dos seres humanos ou a crasis, os temperamentos, as disposições, as características, os estados de saúde e as doenças. Essa concepção orienta, durante mais de dois mil anos, a farmacopeia, os diagnósticos e os tratamentos. ${ }^{2}$ De acordo com essa tradição, a saúde é uma questão de equilíbrio, de harmonia ou de isonomia, entre os quatro humores. O mais puro entre os humores é o sangue; os outros são: a fleuma, a bílis amarela (ou cholè) e a bílis negra (ou melancolia). ${ }^{3}$ Um desequilíbrio no organismo humoral - dyscrasia - causa doença, corrigida pela administração de substâncias, tais como os alimentos, as bebidas ou os preparos farmacêuticos que contrabalanceiam a ausência ou o excesso no organismo e restauram, então, o equilíbrio. ${ }^{4}$

Segundo a "teoria dos humores", esses são constituídos a partir do calor produzido no estômago pelos processos digestivos: o alimento é transformado no

\footnotetext{
${ }^{1}$ ARIKHA, Noga "La Mélancolie et les Passions Humorales". In: GALERIES NATIONALES DU GRAND PALAIS, Mélancolie: Genie et Folie en Occident ...op. cit., p. 232.

${ }^{2}$ Idem.

${ }^{3}$ Idem, p. 233.

${ }^{4}$ Idem, p.234.
} 
fígado, de onde os espíritos vitais no sangue são enviados ao coração e ao cérebro, assegurando um fluxo contínuo entre as paixões e a cognição, a fisiologia e a psicologia, o indivíduo e o ambiente. ${ }^{5}$ Para os estudiosos da Antiguidade, a ordem do corpo físico reflete a ordem do mundo. Os humores correspondem às quatro qualidades naturais - o frio, o calor, o úmido, o seco - e aos quatro elementos $-\mathrm{o}$ ar, o fogo, a água, a terra - de que são constituídos. ${ }^{6}$ Dos elementos originalmente pitagóricos, surgem qualidades humanas; e destas, os temperamentos cujos estados variam em função das quatro estações.

O temperamento sanguíneo é quente e úmido; o temperamento colérico, quente e seco; o temperamento fleumático, frio e úmido e o melancólico, frio e seco. ${ }^{7}$ Os humores não estão presentes em quantidades iguais em cada indivíduo; é a preponderância de alguns humores sobre outros que determina o seu temperamento. $\mathrm{O}$ sangue predomina na pessoa que se mostra serena, de preferência sensual, otimista e é dotada de boa natureza; a bile amarela predomina na pessoa colérica que tende a ser rancorosa e invejosa; a fleuma está presente na pessoa que age e reage lentamente é, por vezes, preguiçosa. E a melancólica tende a ser pensativa e introspectiva. ${ }^{8}$

Os ensinamentos hipocrate-galênicos perduram por muito tempo, perdendo sua acuidade no Ocidente após a queda do Império Romano, porém, continuam vivos na cultura bizantina, reaparecendo em versões árabes nas terras conquistadas. Ressuscitam adiante, no sul da Europa antes de ser, progressivamente, reintroduzidos no mundo medieval europeu. ${ }^{9}$ Desse período em diante, o esquema dos humores passa para a ortodoxia médica até mesmo depois da Renascença. ${ }^{10}$

\footnotetext{
${ }^{5} \mathrm{O}$ cerebelo refina alguns desses espíritos tornando-os menores e mais ágeis. O quente e o frio, a secura e a umidade afetam de modo crucial o curso desses espíritos; e os efeitos dos humores sobre a disposição, o pensamento, a saúde mudam de acordo com o grau de calor, de agitação, de umidade presente no organismo. Idem, p. 235.

${ }^{6}$ Idem.

${ }^{7}$ Idem.

${ }^{8}$ Idem, p.236.

${ }^{9}$ Idem.

${ }^{10}$ Idem, p.237.
} 
As dissecações humanas são retomadas no século XIV, porém, o procedimento não se torna suficiente para corrigir os antigos mestres. Com a chegada da imprensa e a circulação de fontes gregas primitivas, o estudo comparativo da tradição torna-se possível e os trabalhos críticos em anatomia surgem com maior profundidade. As primeiras contestações à "teoria dos humores" ocorrem em 1540, por Vesalius que, por meio de demonstrações em corpos vivos, aponta incorreções na teoria. ${ }^{11}$ Por sua vez, em 1620, Willian Harvey mostra que o sangue realmente circula e que o coração funciona como uma bomba. ${ }^{12}$ Posteriormente a essas novas descobertas, os conhecimentos (medicina, filosofia e astronomia), sustentados pelos humores, caem em descrédito.

Essas reformas, especialmente a de Harvey, são sérias; mas têm influências sobre a teoria, não sobre a prática. Thomas Willis, por exemplo - físico harviano que sugere o termo "neurologia" ou ciência dos nervos e escreve Carebri Anatome abandona os humores e não acredita que um "humor" tenha algum papel representativo na "doença" melancólica, ${ }^{13}$ porém, na prática, Willis sangra seus pacientes. O tratamento dos doentes permanece igual até meados de 1800; de um lado porque as ideias revolucionárias levam tempo para se estabelecer, de outro porque o que constitui uma evidência em medicina pode ser ambíguo; enfim, porque o tratamento médico para a melancolia não é apenas uma questão técnica, visto que seu objetivo é o corpo e a alma. ${ }^{14}$

Os estudos científicos dedicados aos mecanismos mentais intensificam-se ao longo dos séculos XVII e XVIII, levando, eventualmente, à descoberta de novas terapias. A teoria humoral continua funcionando na esfera psicológica. Alguns autores sustentam que, analogamente, a "teoria dos humores" anteciparia a presença dos neurotransmissores e dos hormônios atuais. No fundo, a ideia é a mesma: a

\footnotetext{
${ }^{11}$ Idem, p. 238.

${ }^{12}$ Idem.

${ }^{13}$ Idem.

${ }^{14}$ Idem.
} 
identificação de que as sensações estão relacionadas às substâncias e que o corpo muda quando se está triste ou alegre. E, ainda, que os alimentos e o clima afetam tanto o estado da alma quanto o organismo. ${ }^{15}$ No caso específico da melancolia, o excesso da bílis negra no corpo produz os estados mentais extremos e as desordens físicas, indo do abatimento à loucura. Na explanação aristotélica, os efeitos do humor são semelhantes aos do vinho. ${ }^{16}$ Bílis negra e vinho contêm ar que, em função da mudança da temperatura do organismo, produz, por exemplo, as doenças hipocondríacas. ${ }^{17} \mathrm{De}$ acordo com essa visão, o humor melancólico é, simultaneamente, quente e frio, isto é, de natureza variável. Seus efeitos incluem falta de constância e problemas que vão da apoplexia ao torpor, passando por eutimia, entusiasmo excessivo e loucura. Provocada, em grande parte pela secura excessiva do corpo, como declara Marcílio Ficino em De Vita Libri Três, I, X (Florença, 1489), a melancolia decorre verdadeiramente "de uma

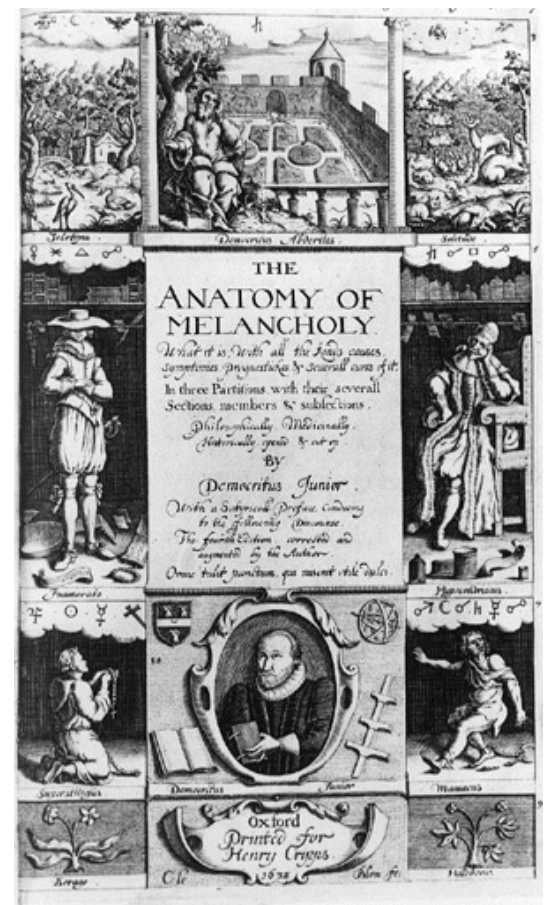
longa insônia, ou de frequentes relações sexuais, do uso de coisas que são muito quentes, de purgação, ou de um exercício exigente, ou de jejum, ou de sede, ou de calor, ou de um vento quente excessivamente seco ou frio". 18

Nesse sentido, a melancolia é um humor que se distingue dos outros humores. Não é possível sofrer de um ataque da fleuma ou do sangue, contudo, é possível sofrer um ataque de melancolia, em outras palavras a bílis negra pode alterar radicalmente o espírito e variar consideravelmente de uma pessoa a

\footnotetext{
${ }^{15} \mathrm{O}$ sistema humoral funciona também porque é flexível na atribuição da temperatura e da umidade aos humores, órgãos, temperamentos e estados de alma. Ele é utilmente esquemático, bastante geral para ser facilmente aplicável e bastante sólido para resistir às variações. Idem, 239.

${ }^{16}$ BERLINCK, Luciana Chauí. Melancolia: Rastros de Dor e de Perda..op. cit.,p.46.

${ }^{17}$ A explanação aristotélica sobre a melancolia, talvez, seja pseudo-aristotélica. No livro Problema $X X X, 1$, que tem seu crédito, o autor identifica que o excesso de bílis negra afeta o hipocôndrio, ou seja, o local do abdômen situado acima do umbigo. Idem, p. 47 e seguintes.

${ }^{18}$ FICINO, Marsílio. Book of Life. Woodstock: Spring Publications, 1996, p. 6.
} 
outra. Robert Burton - considerado como um dos maiores especialista em melancolia - anuncia em sua obra The Anatomy of Melancholy (1621): “a Torre de Babel jamais produziu tanta confusão de línguas quanto o caos da melancolia de variedades de sintomas". ${ }^{19}$ Robert Burton reconhece um estado transitório na condição melancólica "que vai e vem a cada pequena ocasião de tristeza profunda, de necessidade, de doença, de problema, de temor, de dor, de paixão ou de perturbação do espírito". ${ }^{20}$ Nesse contexto, a angústia é uma forma de melancolia. O termo melancolia designa, então, conjunto amplo de sintomas que são atribuídos às ações do humor sobre os órgãos-chave do corpo - o fígado, o coração e cérebro. ${ }^{21}$

Timothy Bright, um teólogo do século XVI, dá continuidade a aspectos específicos do discurso aristotélico sobre a melancolia. Em seu Treatise of Melancholy, publicado em Londres em 1586 - tratado que tem certamente uma influência sobre Shakespeare, talvez em Hamlet - inicia por uma distinção entre o humor e o estado emocional. ${ }^{22}$ Humor e emoção não são idênticos: a melancolia tem um atributo físico e visceral, além do mais a tristeza profunda seria sua marca emocional. $^{23}$

Os conceitos que envolvem a melancolia são porosos, com oscilações de cunho religioso, científico, social, artístico entre outros. Os tratados das paixões que se tornam populares durante o século XVI e XVII constituem os guias para a autoanálise, transformando-se em instrumentos distintos à descrição médica. Esses tratados, sustentados pela psicologia escolástica, reelaboram a genealogia das emoções e

${ }^{19}$ A corrupção e a transformação do sangue ou da bile amarela em bile negra exacerbam as paixões que podem, por sua vez, ultrapassar a razão, perturbando as funções cognitivas ordinárias e suscitando estados extremos de medo ou desespero. Nos dois casos, as mudanças na temperatura e na quantidade de humor melancólico, normalmente presente no corpo, produziam problemas e "alterações" identificados como sendo a melancolia. BURTON, Robert. The Anatomy of Melancholy. Nova York: Farrar \& Rinehart, 1927, p. 397.

${ }^{20}$ Idem, p. 391.

${ }^{21}$ ARIKHA, Noga "La Mélancolie et les Passions Humorales". In: GALERIES NATIONALES DU GRAND PALAIS, Mélancolie: Genie et Folie en Occident ...op. cit., p. 239.

${ }^{22}$ BRHIGHT, Timothy. Traité de La Mélancolie, 1586. Trad. E Cuvellier, Paris, Jérôme Millon, 1996, p. 32 e seguintes.

${ }^{23}$ Idem. 
indicam como usar a razão para frear os excessos. ${ }^{24}$ Permitem a integração num conjunto orgânico das funções do corpo, das paixões, das sensações, da cognição e da razão. ${ }^{25}$

As angústias associadas à consciência moral, como afirma o físico Jacques Ferrand em De la Maladie d'amour ou Melancolie Érotique ${ }^{26}$, produzem sintomas similares àqueles da melancolia humoral. Nesses dois casos, a fisiologia não dá conta plenamente da psicologia moral na medida em que os julgamentos emocionais são produzidos por objetos externos de amor ou ódio, de admiração ou de medo. ${ }^{27}$ Os ataques de melancolia não são causados por algum "fator externo", pelo contrário, é inerente à natureza do indivíduo. ${ }^{28}$

Para os autores abordados até aqui, a paixão melancólica poderia ser afetada pela literatura, pela música, pelas artes, pelos odores, pelos espetáculos, pela temperatura do ambiente e pela umidade. Nesse sentido, a constituição sensorial (fisiológica) determina o estado da alma racional e pensante. A melancolia, assim, pode significar um estado de consciência alterada tanto quanto elevada - aspecto que evoca a criação estética. A associação da melancolia e das manifestações artísticas

\footnotetext{
${ }^{24}$ Os tratados sobre as paixões estão ligados à tradição de psicologia moral baseada numa combinação de ética aristotélica e estóica. ARIKHA, Noga "La Mélancolie et les Passions Humorales". In: GALERIES NATIONALES DU GRAND PALAIS, Mélancolie: Genie et Folie en Occident ...op. cit., p. 240.

${ }^{25}$ É um sistema complexo, derivado do Tomée de Platão através de Galeno e, mais tarde, Thomas de Aquino, no qual as emoções são classificadas de acordo com sua função na economia das paixões, como "concupiscentes" ou "irascíveis." Idem, p. 241.

${ }^{26}$ FERRAND Jacques. De La Maladie d'Amour ou Mélancholie Érotique. Discours Curieux qui Enseigne à Cognoistre 1'Essence, les Caises, les Signes et les Remèdes de ce Mal Fantisque.Paris, 1623, p. 46-47.

${ }^{27}$ Bright acredita que aqueles que se beneficiam de um temperamento geralmente equilibrado - e de um coração em boas condições - são capazes, sem considerar o humor dominante em sua complexidade, de responder pela emoção apropriada aos objetos externos, enquanto que aqueles cujo temperamento é desequilibrado estão mais inclinados a serem afetados pelas respostas humorais. BRHIGHT, Timothy. Traité de La Mélancolie... op. cit., p. 50 e seguintes.

${ }^{28}$ Jacques Ferrand, em seu tratado, coloca que o objeto de amor, por exemplo, pode afetar os espíritos mais por sua ausência inicial do que por uma presença intensamente desejada. $\mathrm{O}$ autor assinala que: "as causas que tornaram este amor melancólico são os desdenhos, as desgraças, a recusa das damas e outros acidentes que tornam o amante descontente e também rabugento no amor". FERRAND Jacques. De La Maladie d'Amour ou Mélancholie Érotique. Discours Curieux qui Enseigne à Cognoistre l'Essence, les Caises, les Signes et les Remèdes de ce Mal Fantisque... op.cit., pp. 46-47
} 
principia com as ideias de Aristóteles que afirma no início do livro Problema $X X X, 1$, que as pessoas excepcionais, dentre as quais os filósofos, os homens de Estado, os poetas ou artistas, tendem a ser melancólicos. ${ }^{29}$

De fato, hoje, torna-se cada vez mais evidente aos psicólogos, aos filósofos e aos neurocientistas que as emoções são fundamentais aos processos cognitivos, à experiência e mesmo à racionalidade. Até então, entretanto, as emoções são concebidas em oposição à razão. ${ }^{30}$ As reflexões sobre as emoções (o medo, a tristeza, as desordens do espírito), através da causa natural - descartando a interpretação mítica - dão margem à formulação da teoria da melancolia preconizada por filósofos e médicos. Não são os deuses, nem os demônios, nem a misteriosa "noite" que atrapalham a razão dos homens; eles são atormentados por uma substância que se acumula em excesso em seu corpo e cujos efeitos, comparáveis aqueles de um vinho, não são mais misteriosos do que os da embriaguez. ${ }^{31}$

A simbolologia da "noite", constantemente presente no ideário medieval, rememora a bílis negra de que falam os primeiros pensadores gregos, ganhando contornos de um conteúdo irracional que se ergue na aparente simplicidade da teoria dos quatro humores (fluidos). ${ }^{32}$ Além disso, a bílis negra não tem a evidência concreta do sangue, da fleuma e da bílis amarela. Ainda que os pensadores antigos acreditassem reconhecê-la nas evacuações e nos vômitos escurecidos de sangue, sua existência é mais idealizada do que observada. ${ }^{33}$ Suas qualidades físicas e seus poderes morais são um postulado da imaginação que transpõe na matéria - ou seja, no corpo sob a forma de doença - os atributos das divindades hostis.

\footnotetext{
${ }^{29}$ APUD. BERLINCK, Luciana Chauí. Melancolia: Rastros de Dor e de Perda...op. cit.,pp. 35-36

${ }^{30}$ Até Descartes, a escolástica aristotélica atenua a duração dessa oposição justificando as emoções. Os movimentos do corpo afetam a alma e os movimentos da alma afetam o corpo - em consequência essas alterações atingem o conhecimento, o raciocínio, a imaginação e a memória. Idem.

${ }^{31}$ STAROBINSKI, Jean. "L'Encre de la Mélancolie". In: In: GALERIES NATIONALES DU GRAND PALAIS, Mélancolie: Genie et Folie en Occident ...op. cit., p. 24.

${ }^{32}$ Idem, p. 25 .

${ }^{33}$ Idem.
} 
Note-se que em alguns casos, a terapia para o controle da bilis negra passa pelo uso dos chamados "talismãs" que, invariavelmente, constituem-se em objetos artísticos. $^{34}$ Este é o caso da Primavera (1480) de Sandro Botticelli, feita sob encomenda de Marsílio Ficino para seu discípulo Lorenzo de Médicis - a obra é concebida para ser um "talismã" precioso contra o adoecimento melancólico. ${ }^{35} \mathrm{O}$ talismã é uma "figura do universo". Algo que concentra as forças, atrações e simpatias dos constituintes do macrocosmo numa imagem única do universo. O "fazedor de imagem", Botticelli, engendra a Primavera para ser admirada por Lorenzo de Médicis em ambiente recluso e silencioso, capaz de despertá-lo às cores e às formas do universo. $^{36}$

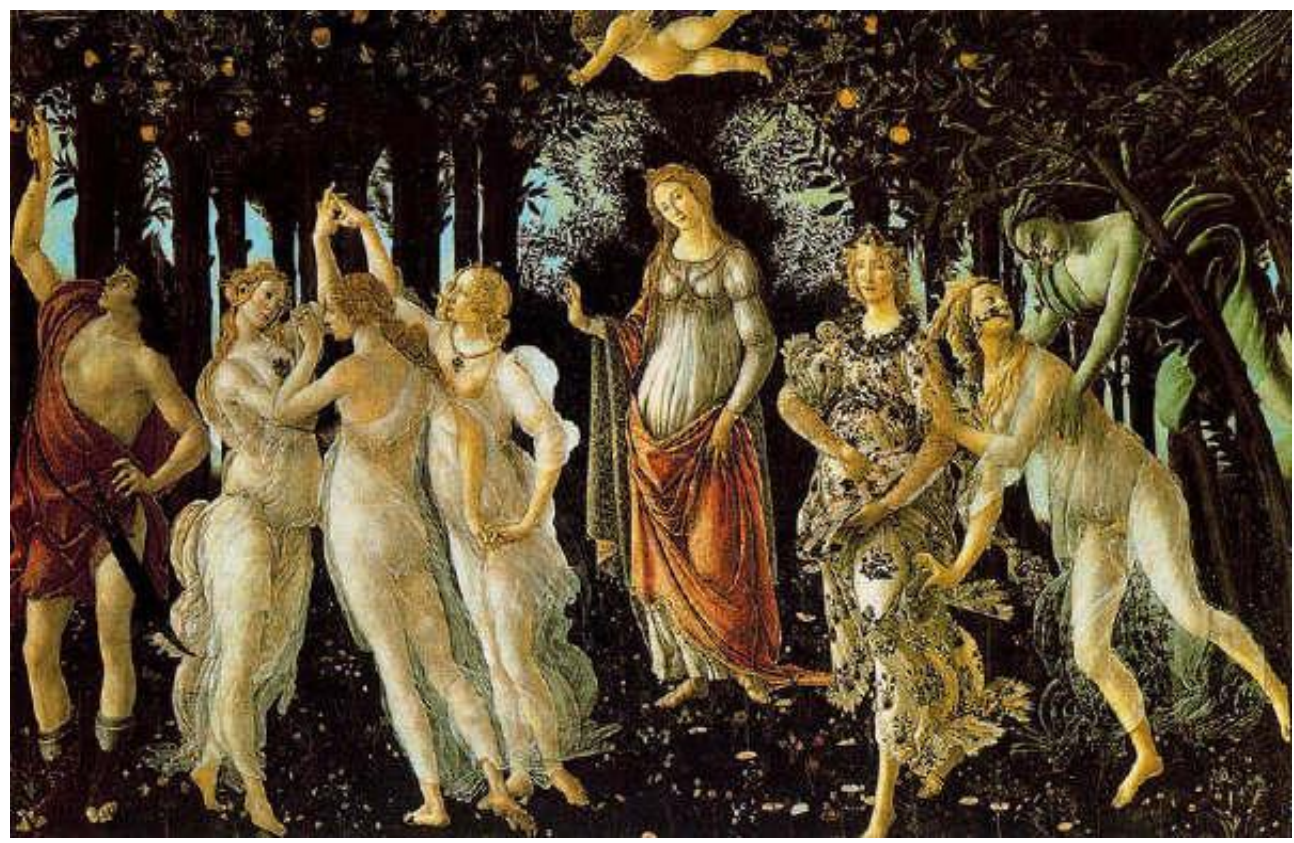

Sandro Botticelli, Primavera, 1470/1480, óleo sobre tela, (203 x 314 cm), Galeria degl'Uffizi. Florença (Itália)

\footnotetext{
${ }^{34} \mathrm{O}$ talismã também pode ser uma joia e deve ser usada sob a veste, junto ao coração, sede da vida. Pode, porém, ser uma escultura ou uma pintura colocada num recinto silencioso e afastada da casa, devendo ser longamente contemplado pelo menos uma vez por dia. BERLINCK, Luciana Chauí. Melancolia: Rastros de Dor e de Perda...op. cit.,p. 28.

${ }^{35}$ YATES, Frances A. Giordano Bruno and the hermetic tradition. Chicago: University of Chicago Press, 1982.

${ }^{36}$ DEMPSEY, Charles. The Portrayal of Love. Botticelli's Primavera and the culture at the time of Lorenzo the Magnificent. Princeton University Press, 1992.
} 
Quando os antigos médicos interpretam o delírio pela efervescência da bílis negra, persistem no domínio das causas sobrenaturais: são influenciados por mitos e pelo raciocínio da época. ${ }^{37}$ Não é de se admirar que dentre os quatro humores, a melancolia se transforme em uma pessoa fictícia (uma alegoria). O sangue, a bílis, a fleuma são irrevogavelmente materiais. Para a melancolia, seria como se ela jamais tivesse deixado de ser uma figura feminina com a face sombria. ${ }^{38}$ Essa mulher surge também nas imagens que mostram o tédio, a dependência, a submissão forçada e a morte. Pela metamorfose o humor/fluído escuro torna-se figura feminina (que se denomina também Mère Ancolie), mas uma segunda transformação coloca essa figura feminina como um elemento da natureza, glacial e seco, veemente, emissário das dores, anunciando todos os sofrimentos e limitações da velhice. Há, ainda, em outros momentos, uma alteração na alegoria da melancolia, agora, figurada em tinta graças a qual a imagem surge obscura e densa com uma luz tênue. ${ }^{39}$

Essas metáforas, relacionadas ao sentimento melancólico, estão presentes em diversas criações estéticas. O pensamento que permeia essa "estética da melancolia" é o de transmutar mal-estar em alegoria e não mais considerá-lo como um humor passageiro. ${ }^{40}$ Adjacente às perspectivas fisiologistas e psicológicas sobre a melancolia - as quais são fortemente vistas no histórico sobre o tema pontuado até aqui aprofunda-se no campo das artes. Na estética, o sentimento torna-se personagem cercada por qualidades de divindade. No presente estudo, a principal orientação está no exame da representação (alegórica ou não) da melancolia e relacioná-la com a poética de Giorgio De Chirico. Para tanto, tem-se como princípio desse exercício a discussão sobre o "anjo de Dürer" e outros exemplos de obras e artistas nos quais uma "estética da melancolia" possa ter surgido.

\footnotetext{
${ }^{37}$ STAROBINSKI, Jean. "L'Encre de la Mélancolie" In: GALERIES NATIONALES DU GRAND PALAIS, Mélancolie: Genie et Folie en Occident ...op. cit p. 24.

${ }^{38}$ Às vezes, as imagens personificadas da melancolia apagam-se e a alegoria reduz-se às imagens do espaço - um espaço animado por objetos, cortado pela substância fluída e fria do vento. Idem, p. 26.

${ }^{39}$ Idem.

${ }^{40}$ LAMBOTTE, Marie-Claude. Estética da Melancolia. Rio de Janeiro: Companhia de Freud, 2000, p. 25.
} 


\section{O Anjo de Dürer e os Herdeiros de Saturno ${ }^{41}$}

(...) os sacerdotes das Musas ficam melancólicos seja desde o início seja à medida que estudam, em decorrência de causas celestes, naturais e humanas. Aristóteles confirma isso em seu livro de Problemas. Pois todos os homens, diz ele, que se distinguiram por alguma faculdade são melancólicos. ${ }^{42}$

Agrippa

Durante a Idade Média surge um novo termo para designar o "estado melancólico": acedia ou acídia (do grego akedia, indiferença). Hoje, essa palavra teria o significado de abatimento do corpo e do espírito, enfraquecimento da vontade, inércia, tibieza, moleza, frouxidão ou ainda melancolia profunda. ${ }^{43}$ De acordo com João Cassiano ${ }^{44}$, acedia era um sentimento predominantemente dos solitários - criado em mosteiro cristão na antiga Palestina, Cassiano adquire grande experiência sobre o tema. Para o autor, acedia liga-se a um espírito maligno, o chamado "demônio do meio-dia”. Esse demônio está associado à tentação da carne, ao pecado e à solidão. ${ }^{45}$

Os monges, acometidos por esse mal, se mostram desgostos com a vida, inquietos, sem desejo pelo trabalho e a estes se recomenda, como tratamento, o exaustivo trabalho físico. Caso o esforço físico não dê resultado, o clérigo deve ser abandonado por sua ordem religiosa à sua própria sorte. Isto porque, durante o período medieval, acedia é um pecado grave equiparado à gula, à fornicação, à inveja e à raiva.

\footnotetext{
${ }^{41}$ Saturno é o planeta da revolução mais lenta, considerado o planeta da melancolia, também de todas as infelicidades e da morte. Paracelso coloca que a constelação de Júpiter e de Saturno seria responsável pela chegada da peste negra. LAMBOTTE, Marie-Claude. Estética da Melancolia...op.cit., p. 23.op.cit., p. 23.

${ }^{42}$ AGRIPPA VON NETTESHEIM, Heinrich Cornelius. De La Philosophie Occulte. Paris: Armand Collin, 1922, p. 125.

${ }^{43}$ SCLIAR, Moacyr. Saturno nos Trópicos ... op. cit., p. 75.

${ }^{44}$ João Cassiano (c. 370- 435) foi um teólogo cristão, do período patrística, monge de Marselha, na atual França.

${ }^{45}$ SOLOMON, Andrew. O Demônio do Meio-Dia: Uma Anatomia da Depressão. Rio de Janeiro: Objetiva, 2002, p. 264 e seguintes.
} 
A melancolia, vista como um fato de ordem religiosa, ao se transformar em acedia, marca a desesperança da salvação, que torna a alma indolente e desleixada, lançando o indivíduo à inércia. A vida dedicada ao louvor, à santidade deveria ser alegre, nesse caso, a melancolia é vista como o "abandono de Deus". 46

Já na visão renascentista, acedia não integra mais a lista dos pecados capitais e passa a ser vista com maior tolerância, transformando-se em tristitia (tristeza), dotada de dois significados diferentes: 1) tristeza mundana (talvez, ocasionada pela perda de bens materiais), na qual a alma se curva frente aos valores terrenos - de conotação pecaminosa e, 2) tristeza virtuosa, inspirada por Deus, que conduz à salvação - algo que atinge os grandes homens.

O texto de Agrippa, De La Philosophie Occulte, articula o humor melancólico às faculdades da alma e a uma hierarquia na ordem da ação e do conhecimento. Na visão do autor, o primeiro grau da melancolia ou a imaginação é o temperamento dos pintores, arquitetos, escultores e mestres de várias artes manuais; o segundo, ou razão, é o temperamento dos físicos, oradores e filósofos; o terceiro, ou intelecto, dos místicos e santos. Nessa direção, segundo, a leitura de Luciana Chauí Berlinck, em seu livro Melancolia - Rastros de dor e perda, se Ficino orienta a realização da Primavera, Agrippa é o pressuposto teórico para duas obras de Dürer: Melancolia I e São Jerônimo. ${ }^{47}$

No reconhecido estudo de Saxl e Panofsky, Dürer 'Melancolia I', os autores examinam iconograficamente a gravura e referem-se ao texto de Agrippa, considerando-o orientador da obra e chamam a atenção para o fato da gravura trazer em seu título o número I, reforçando a descrição de Agrippa de três níveis da melancolia. Isto porque Melancolia I está visivelmente dedicada às artes manuais. Contudo, outros autores questionam: onde estão Melancolia II e III? Logo depois de Melancolia I, Dürer pinta São Jerônimo em seu Estudo. Saxl e Panofsky julgam essa

\footnotetext{
${ }^{46}$ SCLIAR, Moacyr. Saturno nos Trópicos ... op. cit., p. 75.

${ }^{47}$ BERLINCK, Luciana Chauí. Melancolia: Rastros de Dor e de Perda...op. cit.,p. 30.
} 
obra um contraponto e um contradito a Melancolia I. Para os autores, São Jerônimo em seu Estudo seria a Melancolia III, ou a inspiração intelectual daquele que conhece os segredos divinos. Dürer dissera que as duas representações deveriam ser vistas juntas ou simultaneamente. Todavia, informações indicam que a Melancolia II, que transmitiria a inspiração filosófico-profética, não é realizada, ou ainda, seja a gravura O Cavaleiro, a Morte e o Diabo, de 1513.

De fato, a "melancolia renascentista" influencia muitos artistas do período e o exemplo, Albert Dürer, em Melancolia I, 1514, traz o sentimento não mais com uma conotação médica (doença ou sanidade), porém, torna-se metáfora. Na gravura, a melancolia é representada como uma mulher de asas (ou um anjo), potencialmente capaz de grandes voos intelectuais. Mas a Melancolia não está voando, está sentada, imóvel, na clássica posição dos melancólicos, com o rosto apoiado em uma das mãos. A cabeça lhe pesa, cheia de mórbidas fantasias. Às voltas com seus demônios internos, a Melancolia permanece imóvel, como se lhe faltasse ânimo para movimentar-se.

Erwin Panofsky sublinha a melancolia imaginativa como faceta principal da gravura, Melancolia I, de Albert Dürer - o que permite lê-la como produto do imaginário alquímico do período. O Anjo sentado, de fisionomia aborrecida e contrariada, manuseando com displicência a ponta do compasso que tem nas mãos e com o qual poderia "redesenhar" o espaço que o rodeia, é a própria imagem da confusão de alma que é preciso sublimar, encontrando um caminho. ${ }^{48}$ A desarrumação dos objetos à volta de um Anjo, que mais poderia ser uma "dona de casa", incapaz de pôr ordem em suas coisas, é outro dos sinais que o artista fornece. A confusão do exterior torna-se reflexo da íntima confusão, enquanto se aguarda algum sinal ou que alguma coisa de repente mude, ainda que por acaso, mais do que por intervenção própria. ${ }^{49}$ A figura feminina também está atrelada à representação da peste - o flagelo cuja epidemia devastara diversas regiões da Alemanha.

\footnotetext{
${ }^{48}$ PANOFSKY, Erwin.Saturn and Melancholy, ed. by H.W. Janson, 1964.

${ }^{49}$ Idem.
} 


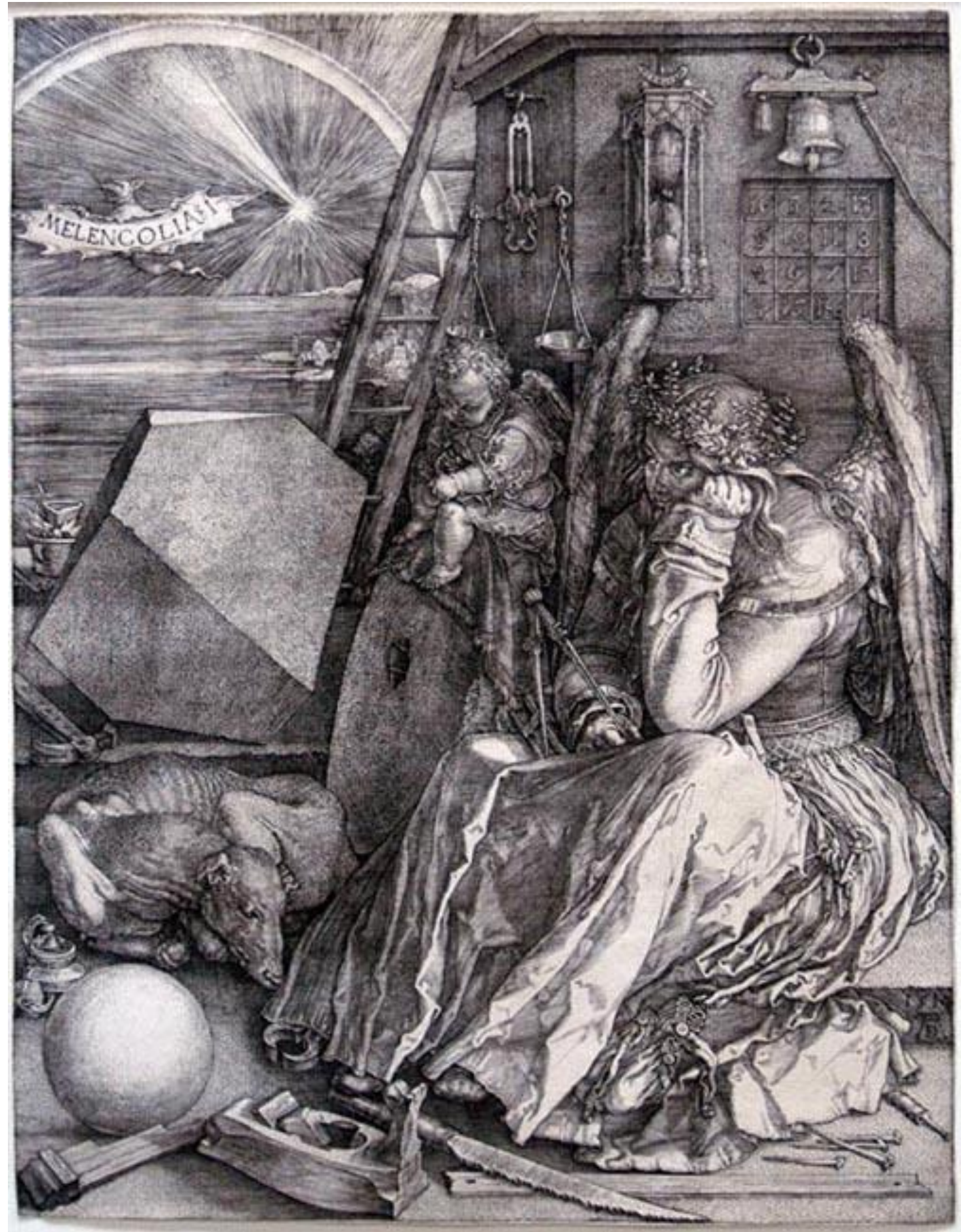

Albert Dürer, Melacolia I, gravura (31 x 26 xm), 1514. Alemanha 


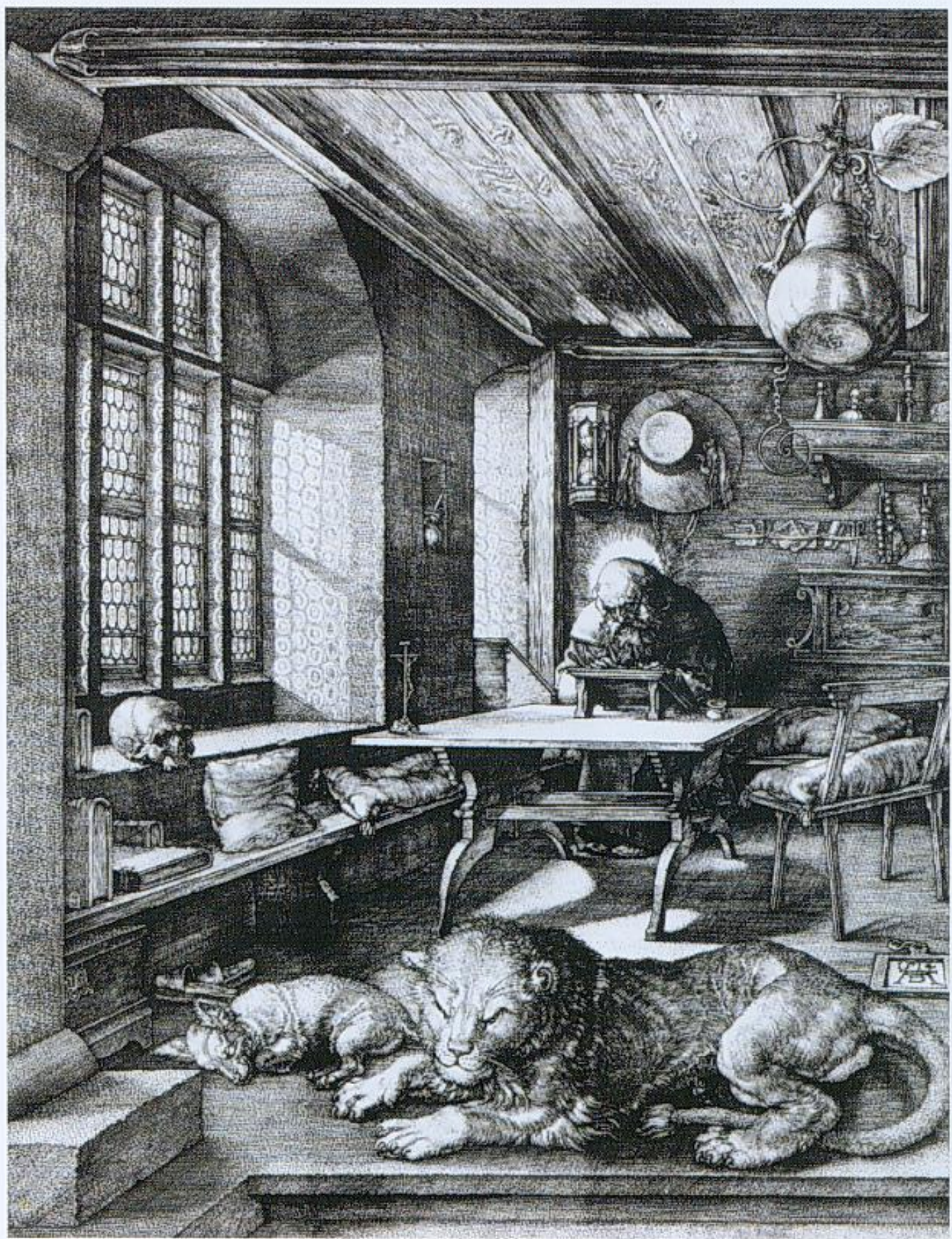

Albert Dürer, São Jerônimo em seu estudo, gravura, (31 x 26 xm), 1514. Alemanha 


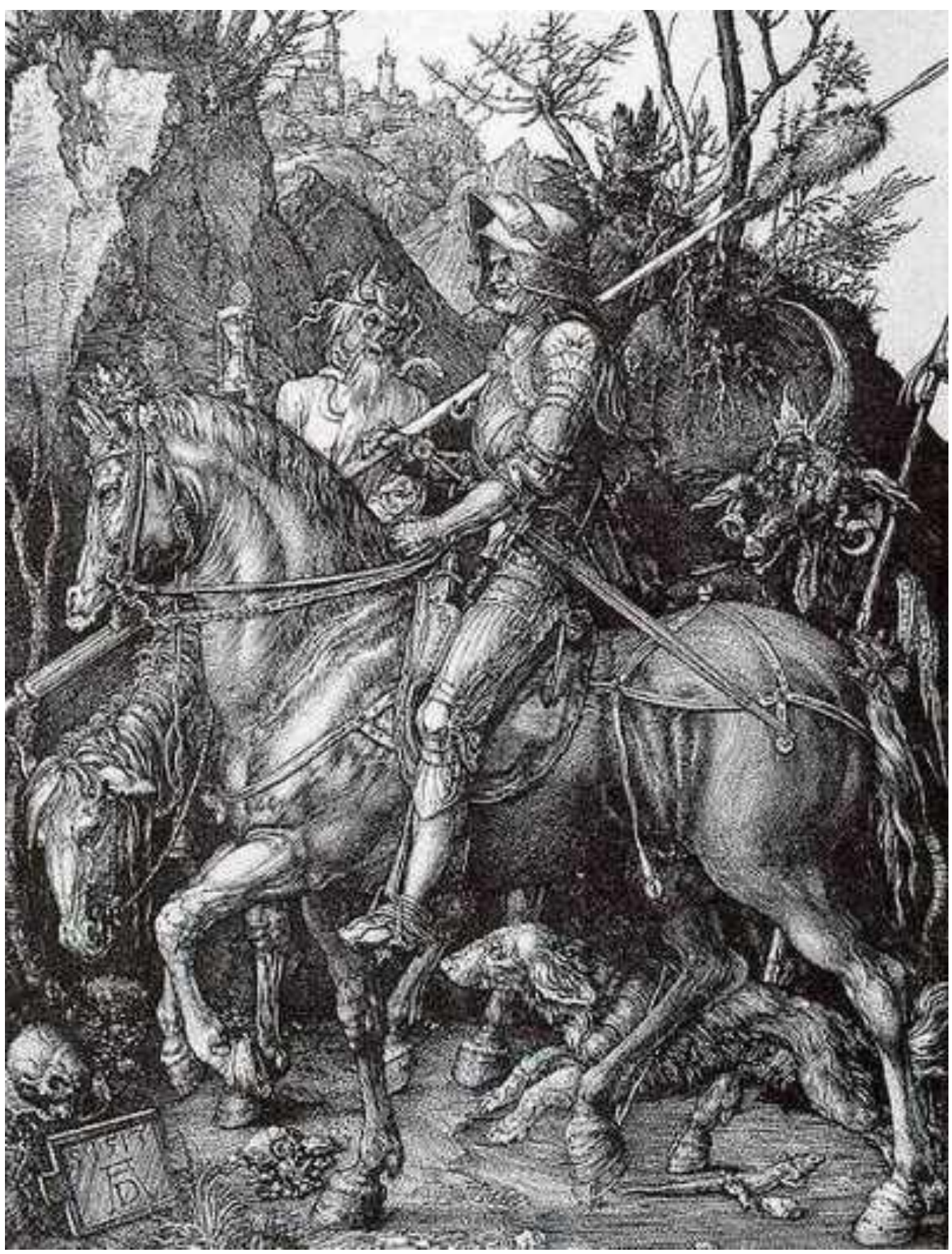

Albert Dürer, O Cavaleiro, a Morte e o Diabo, gravura, (31 x 26 xm), 1513, Museum Boijmans van Beuningen. Holanda 
A esfera pequena, no canto inferior da gravura, à esquerda, será marca de perfeição, tal como o possível arco-íris em que a palavra melancolia se inscreve também pode significar uma transformação positiva e luminosa. ${ }^{50}$ Quase tão destacado quanto o Anjo, está, sempre do lado esquerdo, um poliedro encostado a uma escada que tem por trás um anjo menor, um "putto", semi-adormecido. Walter Benjamin chama a atenção para a pedra, ou ainda, o poliedro que seria um cubo, desenhado de modo peculiar para que não se tenha, desde logo, a noção do equilíbrio das faces. O que faz todo o sentido: os alquimistas falam da pedra cúbica, e da pedra polida, quando desejam referir-se à perfeição que é necessário atingir. ${ }^{51}$

Na gravura, a alma está adormecida e o mesmo sinal é dado pelo cão enrolado que está dormindo aos pés do Anjo. ${ }^{52} \mathrm{O}$ cão adormecido, fiel companheiro do artista em muitas das gravuras com referências alquímicas conhecidas, é outra alusão à melancolia. O organismo canino, no período, está ligado à figura do baço. À época, cães com face melancólica seriam os melhores: um cão alegre e amistoso não seria confiável para a guarda da propriedade. No sentido metafórico, a figura do cão negro é remetida à memória. Como o cão, a memória é um fiel acompanhante do homem. Memória às vezes sombria, como algo evidenciado pela própria cor escura do animal, corresponde à obsessão renascentista de evocar, lembrar. O melancólico lembra, porém, o que recorda é triste. O cão adormecido representa a memória desligada, imersa em profundo sono. ${ }^{53} \mathrm{O}$ mar no horizonte da gravura relembra a inclinação dos melancólicos para as longas viagens, remetendo-se à transitoriedade do mundo frente à inércia do humano.

O Anjo traz chaves em sua cintura. Para o artista tais "chaves" são indispensáveis, pois todo o processo é cifrado, é secreto e não é dado a qualquer um. ${ }^{54}$ No chão, uma bolsa. Não por acaso, nos desenhos preparatórios da gravura, Dürer

\footnotetext{
${ }^{50}$ Idem.

${ }^{51}$ BENJAMIN, Walter. Origine du Drame Barroque Allemand. Paris: Flammarion, 1985.

${ }^{52}$ Idem.

${ }^{53}$ PANOFSKY, Erwin. Saturn and Melancholy ...op. cit.

${ }^{54}$ Idem.
} 
escreve que as chaves significam poder e a bolsa, riqueza. Metáforas: "quem tem chaves pode abrir portas, inclusive, as do céu",55 "a bolsa remete a uma característica tradicionalmente atribuída aos melancólicos, avareza" ${ }^{56}$ Deve-se mencionar, ainda, que Saturno é frequentemente representado com bolsa e chaves, a divindade é vista como responsável pelo processo de cunhagem de moedas. A profusão de objetos na obra de Dürer é relevante para o presente estudo - chama-se atenção que na produção de De Chirico, os objetos tem grande peso e importância, como se verá proximamente neste estudo.

Em Dürer, os objetos são os utilizados cotidianamente, em vários ofícios, na ciência: uma balança, uma ampulheta, uma sineta, martelo, serrote, pregos. Aparentemente são ferramentas que não estão ali para serem usadas; ao contrário, os elementos sugerem a imobilidade, expressa em ponto culminante nas imagens do Anjo e do cão. ${ }^{57} \mathrm{~A}$ ampulheta mostra o tempo congelado: os dois compartimentos contêm a mesma quantidade de areia. Há ainda uma tábua numérica, uma clara alusão à geometria, à época, valorizada como verdadeira fonte do conhecimento, excluindo-se a visão teórica e enfatizando-se os aspectos práticos. A tábua numérica apresenta-se ao lado de instrumentos humildes como o martelo e o serrote, emprestando à geometria um caráter essencialmente humano. ${ }^{58}$ Benjamin afirma que a transição entre o melancólico e o mundo se faz por intermédio das coisas, não das pessoas. Acumular riqueza, roupas, obras de arte, propriedades - é o imperativo dessa época, mesmo que depois os objetos fiquem sem utilidade, como acontece na gravura. ${ }^{59}$

A gravura de Dürer é alegórica, o que não deixa de ser apropriado - em se tratando de melancolia, como se percebe, alegorias não são raras. $\mathrm{O}$ anjo ou a mulher de Melancolia I poderia representar, para alguns autores, a peste negra que assola a

\footnotetext{
${ }^{55} \mathrm{Idem}$.

${ }^{56}$ Idem.

${ }^{57}$ Idem.

${ }^{58}$ Idem.

${ }^{59}$ BENJAMIN, Walter. Origine du Drame Barroque Allemand ...op.cit.
} 
Europa à época e aproxima os sentimentos de morte e dor aos melancólicos. ${ }^{60}$ Nesse caso, a melancolia é interpretada como uma espécie de "psicose da peste". Aos 34 anos de idade, Dürer vive a peste em Nuremberg e expressa em suas gravuras as experiências vividas. A Melancolia poderia ser o que autores chamam de "fantasia" que, apesar de ser versada no decifrar dos símbolos, não apaga a iconografia própria à genialidade melancólica do período.

Ao completar o sentido alegórico, o anjo é apresentado com o rosto na sombra, olhar perdido ao longe e a cabeça apoiada numa das mãos, em posição semelhante ao Pensador de Michelângelo - nessa ilustração e, em diversas outras, desenhadas e talhadas por Dürer, há referências a essa obra-prima. Também, nessa direção, o pequeno "putto", que lê uma inscrição segurando um sextante nas mãos, representaria o "gênio da história", que tenta classificar os acontecimentos em ordem cronológica ou, então, o "gênio da astrologia", que se dedica à previsão do mundo futuro. ${ }^{61}$ Assinala-se, aqui, que fazer da melancolia uma alegoria é não mais considerála como um humor passageiro, submetido à existência humana, mas atribui-la as qualidades de uma divindade é índice de um projeto estético construído sobre os processos da melancolia, que visa submeter os elementos do meio a uma arte da composição. $^{62}$

Ao se considerar as três gravuras designadas por Dürer como "Meisterstiche",63, (O Cavaleiro, a Morte e o Diabo, 1513, São Jerônimo em seu Estudo, 1514 e a Melancolia I, 1514), pode-se notar que elas encerram, entre outros símbolos, o crânio humano, a ampulheta, o cão (além do leão de São Jerônimo), animais fantásticos e signos cabalísticos. ${ }^{64}$ De igual formato, elas mergulham no claro-

\footnotetext{
60 “(...) todos os atributos da melancolia, até a própria melancolia representada por essa figura feminina alada de rosto de sombra, referir-se-iam à personificação da Peste, como uma hidra monstruosa cujos contornos se teriam enfim precisado, mas que não se ousaria, entretanto olhar de frente". LAMBOTTE, Marie-Claude. Estética da Melancolia ...op.cit., p. 20.

${ }^{61}$ Idem, 23.

${ }^{62}$ Idem.

63 "Gravuras Master".

${ }^{64}$ LAMBOTTE, Marie-Claude. Estética da Melancolia...op.cit., p.19.
} 
escuro oriundo da segunda viagem de Dürer à Veneza e permitem a divisão da luz em espaços variados. ${ }^{65}$ A presença da morte, o inexorável escoamento do tempo e a centralidade das personagens (o Cavaleiro, São Jerônimo e a Melancolia) definem o conjunto de gravuras. O conjunto expressa a "face negra" da melancolia, na tradição antiga que relembra o gênio da morte que cerca o humano. Ao retomar as interpretações de Panofsky, o Cavaleiro representaria a vida do cristão no mundo material da ação e da decisão; São Jerônimo, o santo no mundo espiritual da contemplação sagrada e a Melancolia, aquela do gênio secular presente no mundo racional e imaginativo das ciências e das artes. ${ }^{66}$

Contudo, a "elevação intelectual", contida na alegoria de Melancolia I, apresenta dissonâncias inerentes ao contexto renascentista. Como diz Panofsky, "a teoria e a prática não se conjugam bem, é o que mostra a composição de Dürer; e o resultado é a incapacidade de agir e o humor sombrio". ${ }^{67}$ Doença, causada pelo pensar excessivo, a melancolia é também a enfermidade que mais leva a pensar, em outros termos, alimenta a reflexão filosófica e a criação poética. Para os homens de "elevada intelectualidade", o preço a pagar seria o isolamento, como no caso de Montaigne, que se retira da vida pública para, em seu castelo, refletir sobre a clássica questão: “Que sei eu?" M8 Montaigne não é propriamente um eremita porque continua atento aos problemas de seu tempo, mas é "o melancólico em sua torre solitária”, segundo seu amigo e poeta John Milton (1608 - 1674), em Il penseroso (O pensativo), publicado em 1654. O poema é uma alusão aos tempos sombrios e meditativos cercados pela peste negra. Nele o poeta saúda a "boa" melancolia que leva ao amor de Deus e que seria própria dos intelectuais inconformados com a existência humana. ${ }^{69}$

Nesse sentido, poderia se considerar, como "a torre solitária - o templo da melancolia", a biblioteca - o mundo cercado pelos livros que refletem algo limitado e,

\footnotetext{
${ }^{65}$ Idem.

${ }^{66}$ PANOFSKY, Erwin.Saturn and Melancholy, op. cit.

${ }^{67}$ Idem.

${ }^{68}$ SCLIAR, Moacyr. Saturno nos Trópicos ... op. cit., p. 88.

${ }^{69}$ Idem, p. 87.
} 
de certa forma, controlado em oposição às descobertas do "novo mundo", no período renascentista. Cervantes, em diversas passagens de seu romance, mostra a figura desgastada e "fora de seu tempo" do cavalheiro andante. A personagem Sancho Pança seria considerada sua antítese e, por sua vez, mais adaptada às novas demandas. Desprovido de pudores e com um profundo senso prático, Sancho Pança vive de acordo com as solicitudes do período, ao contrário do seu senhor, que almeja as honrarias de uma vida cavaleresca que não existe mais. Dom Quixote é levado à loucura pelos livros - melancolia e loucura têm suas ligações (às vezes se complementam, às vezes se contradizem) - uma tênue linha as divide. O Cavalheiro da Triste Figura é limítrofe, reflete a melancolia dos fidalgos que vivem a aventura mítica de um passado sem retorno. Ao longo do período renascentista, o progresso e o predomínio do comércio impelem a novos comportamentos econômicos e sociais que são rejeitados pelo feudal Dom Quixote: “(...) de pouco dormir e muito ler lhe resseca o cérebro" - sua "triste figura" pode ser tomada como a projeção corporal de seu temperamento: seco por dentro, seco - magro - por fora (isto é, a condição física dos melancólicos).

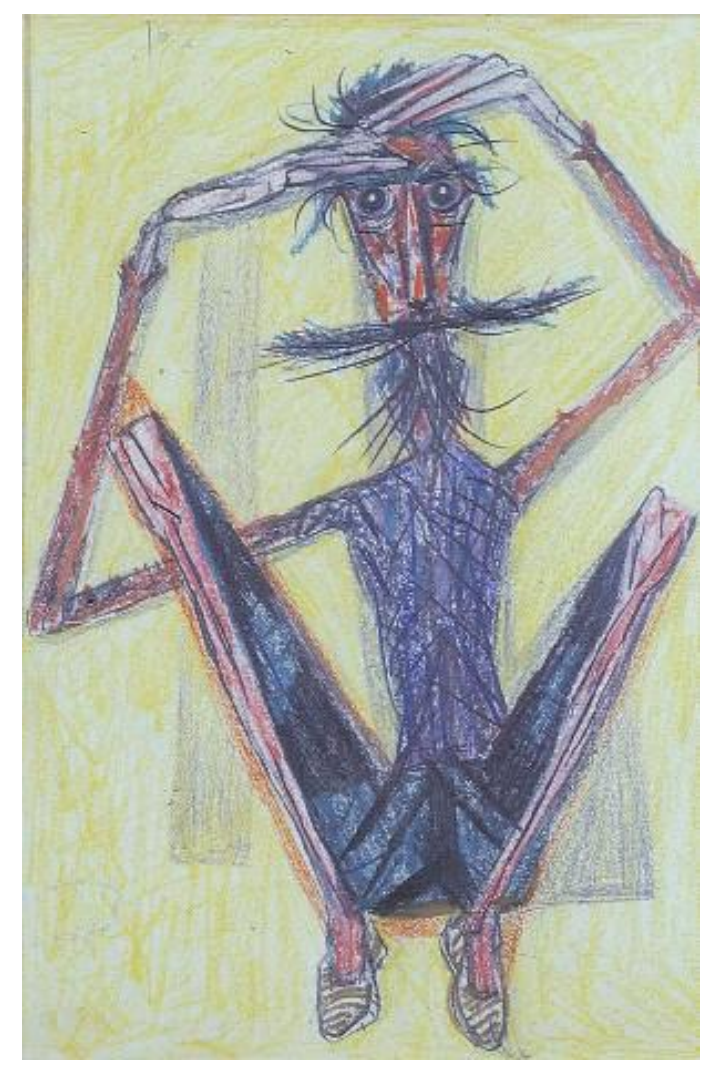

Candido Portinari, Dom Quixote de Cócoras com Ideias Delirantes, lápis sobre papel, (37 x 24,6 cm), 1956, Museus Castro y Maia, Rio de Janeiro. Brasil 
A ideia do fidalgo, do príncipe ou do "monarca melancólico" é recorrente à época e é transmitida em inúmeras manifestações artísticas. No teatro, por exemplo, Shakespeare cria Hamlet, um personagem desiludido com o mundo; incapaz de vingar a morte do pai e dono de uma imaginação superior que adota a melancolia como uma resposta ao mundo doente no qual vive. Shakespeare aborda o mal-estar com transparência, empatia e complexidade. Dá ao seu personagem astúcia e sentimentos de autodestruição. No momento em que Hamlet é encenado, a melancolia é tanto um elogio quanto uma doença - aos menos privilegiados social e economicamente, a melancolia é vista como um mal a ser extirpado (um melancólico é candidato, assim como a escória da sociedade, a integrar a Nau dos Insensatos). ${ }^{70}$ Para os mais abastados, o humor é o que daria o tom de sua genialidade - a retomada da tradição clássica fornece os sustentáculos para esse pensamento.

No drama barroco é frequente a figura do "príncipe melancólico". No período da reforma e contra-reforma, crescem as obras que tratam da moralidade do cotidiano e da honestidade das pequenas coisas. Para os intelectuais, o "absurdo da existência" os aproxima do terror da morte, do mundo enlutado. No mundo protestante, a intervenção divina adquire novos aspectos: nele as ações humanas, baseadas na moral e na racionalidade, trazem consequências divinas. Para Walter Benjamin, o príncipe melancólico barroco é aquele que, dotado de poderes absolutos, sabe que não pode mais contar somente com a intervenção divina em relação ao mundo. ${ }^{71}$ Daí, o caráter dramático da qual a alegoria barroca não pode prescindir. O homem barroco retoma a natureza como objeto da ciência, no sentido de dominá-la, mas nesse processo, se afasta de seu potencial simbólico. Do mesmo modo, a melancolia barroca possui

\footnotetext{
${ }^{70}$ A Nave dos Insensatos de Hieronymus Bosch, Paris, Louvre, é uma sátira à corrupção da sociedade e do clero, com referências ao folclore e à literatura. O motivo da barca dos loucos é corrente na casa de Flandes de "1400". A barca é alegoria que surge nos desfiles carnavalescos de Brabante e dá nome a uma confraria que coloca na berlinda as pessoas poderosas da localidade. Entre as influências literárias existentes na obra de Bosch está o poema satírico de Sebastian Brant Narrativas. Porém, a suprema exaltação do tema se encontra no Elogio a loucura, de Erasmo (1509).

${ }^{71}$ BENJAMIN, Walter. Origine du Drame Barroque Allemand ...op. cit.
} 
implicações expressivas de um mesmo sentimento: o medo, a necessidade de domínio daquilo que aparece como contraditório e externo à consciência. ${ }^{72}$

No histórico sobre as diversas concepções relativas ao sentimento melancólico se percebe a proliferação de discursos que variam entre: o médico que encerra na fisiologia seus sintomas e a interpreta como doença física com incidências psíquicas secundárias; o médico-filosófico que reflete sobre sua tipologia e sobre a relação do humor com o sentimento, da alma com o corpo e, o filosófico-moralista que se dedica à doença da alma ligada intrinsecamente ao desgosto pela vida. ${ }^{73}$ Os "herdeiros de saturno" (Dürer, Cervantes, Shakespeare, entre outros) transformam o humor e o malestar em alegoria, metáfora ${ }^{74}$ e, depois, pode-se dizer, criam uma "estética da melancolia" que passa pelo ideário medieval (como um pecado capital), adentra o Renascimento (às vezes como doença; outras vezes como traço de genialidade retomando às ideias aristotélicas), ressurge no Barroco (como o medo inexorável frente à morte), no Rococó (passa a ser a "doce melancolia") e, finalmente, será base primordial do Romantismo - as fontes românticas nutrem a poética de Giorgio De Chirico e o transformam em um "herdeiro de saturno".

As percepções românticas sobre a melancolia varrem a Europa e adquirem status social. Na Itália, por exemplo, todos aqueles que acreditam serem gênios esperam ser melancólicos. Ingleses, que viajam para as terras italianas e lá convivem por certo tempo, regressam para casa gabando-se da sofisticação adquirida e expressa em seus atributos melancólicos - uma vez que somente ricos podem arcar com os custos das viagens, a melancolia torna-se uma doença aristocrática inglesa. ${ }^{75}$ Porém, é na França que o humor configura-se em "doce melancolia" que, mais tarde, é o sustentáculo do ideário romântico.

\footnotetext{
${ }^{72}$ Idem.

${ }^{73}$ PIGEAU, Jackie. Metáfora e Melancolia: ensaios médico-filosóficos. Rio de Janeiro: PUC Rio/Contraponto, 2009, p. 119.

74 "Bem metaforizar é contemplar o semelhante, escreve Aristóteles na Poética (1459 a7)". Idem, p. 136.

${ }^{75}$ SOLOMON, Andrew. O Demônio do Meio-Dia: uma anatomia da depressão.. op. cit., p. 286.
} 
Nesse contexto, o próximo passo na busca de uma provável "estética da melancolia" presente na produção de Giorgio De Chirico direciona-se para o que significa a "doce melancolia", nos séculos XVIII, XIX e seus desdobramentos no Romantismo - do qual surgem as declaradas influências do pintor. Nesse ponto, torna-se perceptível que é pela vertente romântica que De Chirico delineia o início de sua produção: elabora suas primeiras telas, explorando os temas bocklinianos, tais como, cidades, marinhas e centauros. Realiza, ainda, o Autorretrato (1911), A Melancolia (1913) e o Enigma do Oráculo (1909), que se remete ao templo de Delfos e ao mito de Apolo. ${ }^{76}$

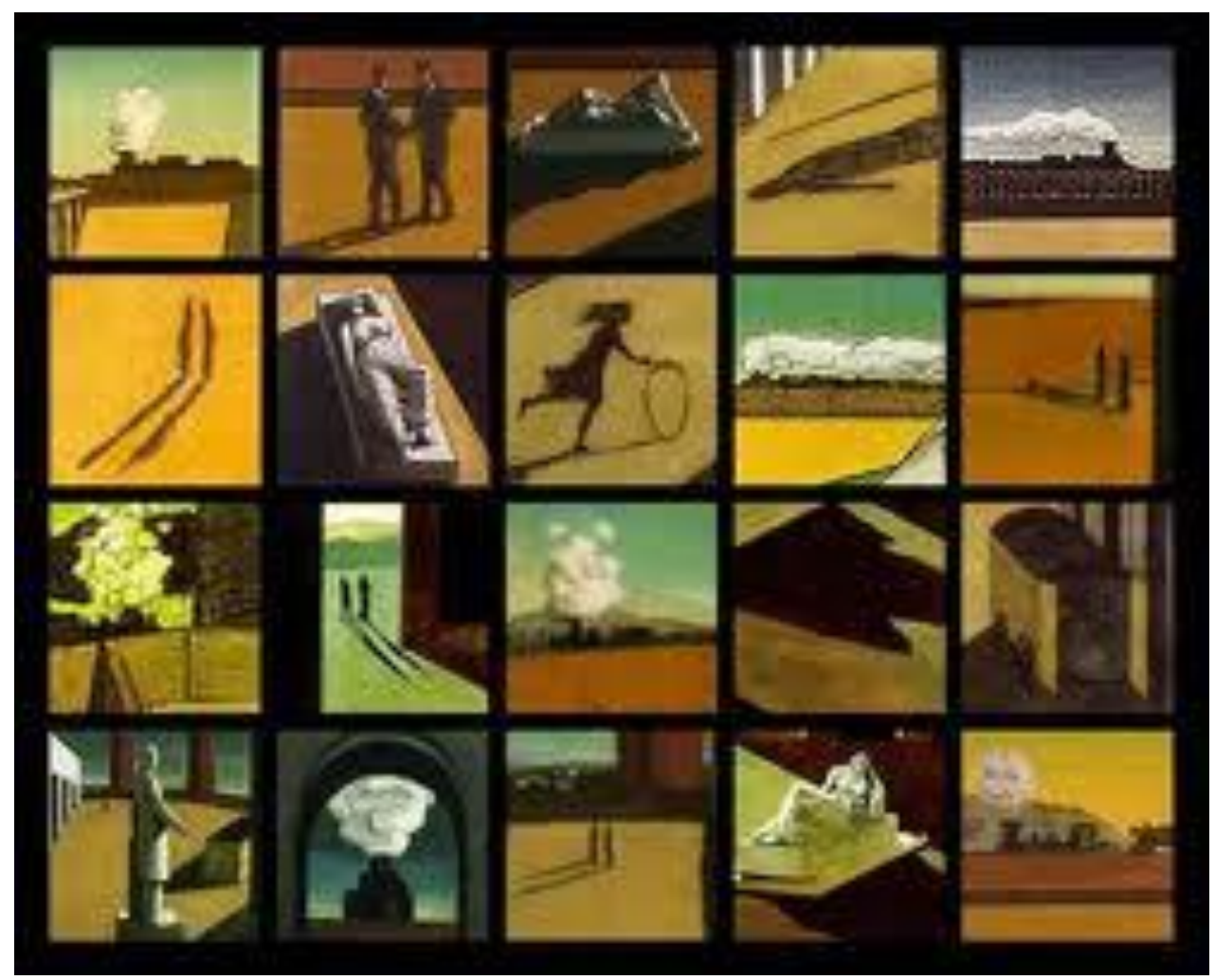

Mosaico com diversos detalhes da produção artística de Giorgio De Chirico.

76 Nas obras citadas e, principalmente, no Autorretrato surge temática da melancolia expressa no modo em que a cabeça posa sobre o braço, numa referência ao retrato de Nietzsche. FAGIOLO DELL'ARCO, Maurízio. “L'Opera Completa di De Chirico. 1908-1924”, Clacissi dell'Arte Rizzoli, Milano, 1984. 


\section{A "Doce Melancolia" - Séculos XVIII e XIX}

Em 1765, a Enciclopédia afirma que a melancolia é "efeito da fraqueza de alma e dos órgãos" somada à "falsa ideia", ou seja, alma e corpo envoltos por devaneios e ilusões. No mesmo ano, Anne Charles Lorry, com a publicação de $D e$ Melancolia et morbis melancholis, introduz a noção de "melancolia nervosa", questiona a antiga teoria humoral e contribui para a elaboração de uma acepção nova do termo, deslocando-a para as fronteiras da "loucura raivosa". No domínio das artes, as representações da melancolia são raras na França até o fim do Antigo Regime - isto porque o sentimento é considerado uma doença tipicamente aristocrática inglesa, contudo, a expressão "doce melancolia" emerge gradualmente em território francês. Dois poemas do inglês John Milton L'allegro e Il penseroso ${ }^{78}$ (publicados em 1654 já citados neste estudo) contribuem fortemente para a expansão de uma conotação nova da melancolia, transformando-a em um sentimento sereno e até mesmo bemvindo. $^{79}$

Na França, essa "doce melancolia" ganha uma noção mais exata no final do século XVII e é registrada no Dicionário Universal, em 1690, surgindo como:

MELANCOLIA significa também um sonho agradável, um prazer que encontramos na solidão, para meditar, para sonhar com suas coisas, seus prazeres ou seus desprazeres. Os poetas, os amantes entretêm sua melancolia na solidão. Os versos queixosos são o fruto de uma doce melancolia. ${ }^{80}$

A última edição do Dicionário de Trévoux, em 1771, completa esse dado semântico:

${ }^{77}$ STAROBINSKI, Jean. Histoire du traitement de la mélancolie des origines à 1900, Bâle: Geigy, 1960, p. 46.

${ }^{78}$ Il Penseroso é uma homenagem do poeta inglês ao seu amigo Montaigne.

${ }^{79}$ Idem.

${ }^{80}$ FURETIÈRE, Antoine. Dictionnaire universel... La Haye e Rotterdam, 1690. 
Há uma melancolia doce, que é apenas um sonho agradável, uma deliciosa tristeza, se é possível dizer assim. É a situação de uma alma que, se recusando às tentações vivas que a cansarão, sabe deixar-se levar às ilusões dos sentidos e encontrar o prazer na meditação daquilo que causa seu sofrimento. Os amantes entretêm sua melancolia na solidão. ${ }^{81}$

No século XVIII, o vocábulo "melancolia" vê seu domínio semântico estender-se para além da esfera médica e filosófica para abordar aquela, mais sutil, dos sentimentos. E a França, que parece ter deliberadamente rejeitado fora de suas fronteiras os excessos da melancolia nervosa, empenha-se a elaborar uma iconografia original para esta nova noção de "doce melancolia". Essa iconografia manifesta-se na obra do pintor Jean-Antoine Watteau (1684 - 1721) - tanto que nos séculos posteriores, Watteau transforma-se no "pintor da melancolia". Em 1856, os divulgadores de sua obra observam no ensaio, La Philosophie de Watteau: "por detrás das palavras sorridentes", das festas galantes, há "certa tristeza musical". ${ }^{2}$ No ano seguinte, Baudelaire, no quarteto extraído de "Phares" das Flores do Mal, confirma a figura do pintor como melancólico:

Watteau, um carnaval de corações ilustres, Quais borboletas a pulsar por entre os lírios, Cenários leves inflamados pelos lustres Que à insânia incitam este baile de delírios. ${ }^{83}$

Donald Posner, em 1974, desconstrói esse mito, criado em torno da figura do pintor. ${ }^{84}$ Demonstra que os escritores da "boêmia galante", do ano de 1830, acentuam a interpretação melancólica da obra de Watteau em oposição "à época materialista na qual viviam". 85 Para esses escritores, o século XVIII, cuja obra de Watteau representa a quintessência, "estava voltado à arte e à beleza, ao refinamento da sensibilidade

${ }^{81}$ Dictionnaire universel françois et latin vulgairement appelé dictionnaire de Trévoux... nouvelle édition, Paris, 1771, t. V, p. 911.

${ }^{82}$ GONCOURT, Edmond e Jules. "La philosophie de Watteau", o Artista, 7 de set. 1856, p. 127-129.

${ }^{83}$ BAUDELAIRE, Charles. "Os faróis", em Flores do Mal, 1857 (Trad. Ivan Junqueira)

${ }^{84}$ POSNER, Donald. "Watteau melancólico: a formação de um mito". In: Bulletin de la Société de l'histoire de l'art Français, 1974, p.345-361.

${ }^{85}$ Idem. 
estética e à busca de prazeres plenos de elevação". "86 Posner relaciona esta aspiração com uma relação "aristocrática" particularmente forte a partir de 1830 e que promoveria a "civilização do século XVIII". O autor chama atenção para o fato de que Watteau é um homem atingido pela melancolia, todavia, não a projeta em suas telas, nas quais se vê a alegria por toda parte. O homem Watteau, inegavelmente, aparece aos seus biógrafos do século XVIII como um espírito melancólico. ${ }^{87}$ Mas é somente a partir do ano de 1745 e, em certos meios, que se elabora a interpretação exclusivamente frívola e deliberadamente depreciativa de sua arte.

A melancolia de Watteau não é uma invenção do século XIX. Desde 1725, Laurent Josse Leclerc ${ }^{88}$ afirma que "o trabalho assíduo o havia tornado um pouco melancólico." Leclerc insiste em retratar o artista como frágil e cerebral: "Watteau era de uma constituição fraca, tinha o espírito infinito, falava pouco, mas muito bem, meditava quase sempre (...) era inquieto, sempre descontente consigo mesmo." ${ }^{89}$ Dois anos mais tarde, Jean de Julienne, o principal colecionador de Watteau e responsável pelo registro de sua obra, reafirma este retrato do artista introvertido meditativo: “(...) tinha o espírito vivo e penetrante, e os sentimentos elevados (...) Meditava quase sempre $^{90}(\ldots) "$. Um pouco mais tarde, em 1744, Edme François Gersaint, vendedor e “amigo" do pintor", confirma o seu caráter reflexivo e melancólico: "Ele tinha o caráter inquieto e instável”, “(...) gostava muito da leitura, era o único divertimento

\footnotetext{
${ }^{86}$ FAROULT, Guilherme. "'A doce melancolia', segundo Watteau e Diderot - Representações melancólicas nas artes da França do século XVIII". In: GALERIES NATIONALES DU GRAND PALAIS, Mélancolie: Genie et Folie en Occident ...op. cit p. 274 e seguintes.

${ }^{87}$ POSNER, Donald. "Watteau melancólico: a formação de um mito". In: Bulletin de la Société de l'histoire de l'art Français ...op. Cit., p. 345.

${ }^{88} \mathrm{O}$ ensaio de François Moureau, "Watteau em seu tempo" é uma das primeiras biografias do artista. In: GRASSELLI, Margaret Morgan; ROSENBERG, Pierre (org.). Watteau 1648-172. WashingtonParis-Berlin, 1984-1985, p.503-508.

${ }^{89}$ Grand Dictionnaire historique de Moreri, Paris, 1725. In: ROSENBERG, Pierre. Vies anciennes de Watteau, Paris, 1984, p.10.

90 FAROULT, Guilherme. "'A doce melancolia', segundo Watteau e Diderot - Representações melancólicas nas artes da França do século XVIII". In: GALERIES NATIONALES DU GRAND PALAIS, Mélancolie: Genie et Folie en Occident ...op. cit p. 274 e seguintes.

${ }^{91}$ GLORIEUX, Guillaume. À l'enseigne de Gersaint. Edme-François Gersaint, marchand d'art sur le pont Notre-Dame (1690-1750), Seyssel, Champ Vallon, 2002, p.90-113.
} 
que buscava como lazer; embora sem letras, escolhia de maneira sadia uma obra do espírito". 92

Sua produção, contraditoriamente, remete à alegria e torna-se um convite para festas e comemorações. Em suas telas, os títulos explicitamente festivos abundam: Les Plaisirs du bal ${ }^{93}$ (1731), La Récréation italienne ${ }^{94}$ (1733), entre outros. Alguns títulos são declarações de felicidade: Le Plaisir pastoral ${ }^{95}$ (1729), Les Charmes de la vie 96 (1730). Numerosos títulos se ligam, então, à temática da iniciação amorosa: La Gamme d'amour' ${ }^{97}$ (c. 1729), Leçon d'amour ${ }^{98}$ (1734), entre outros.

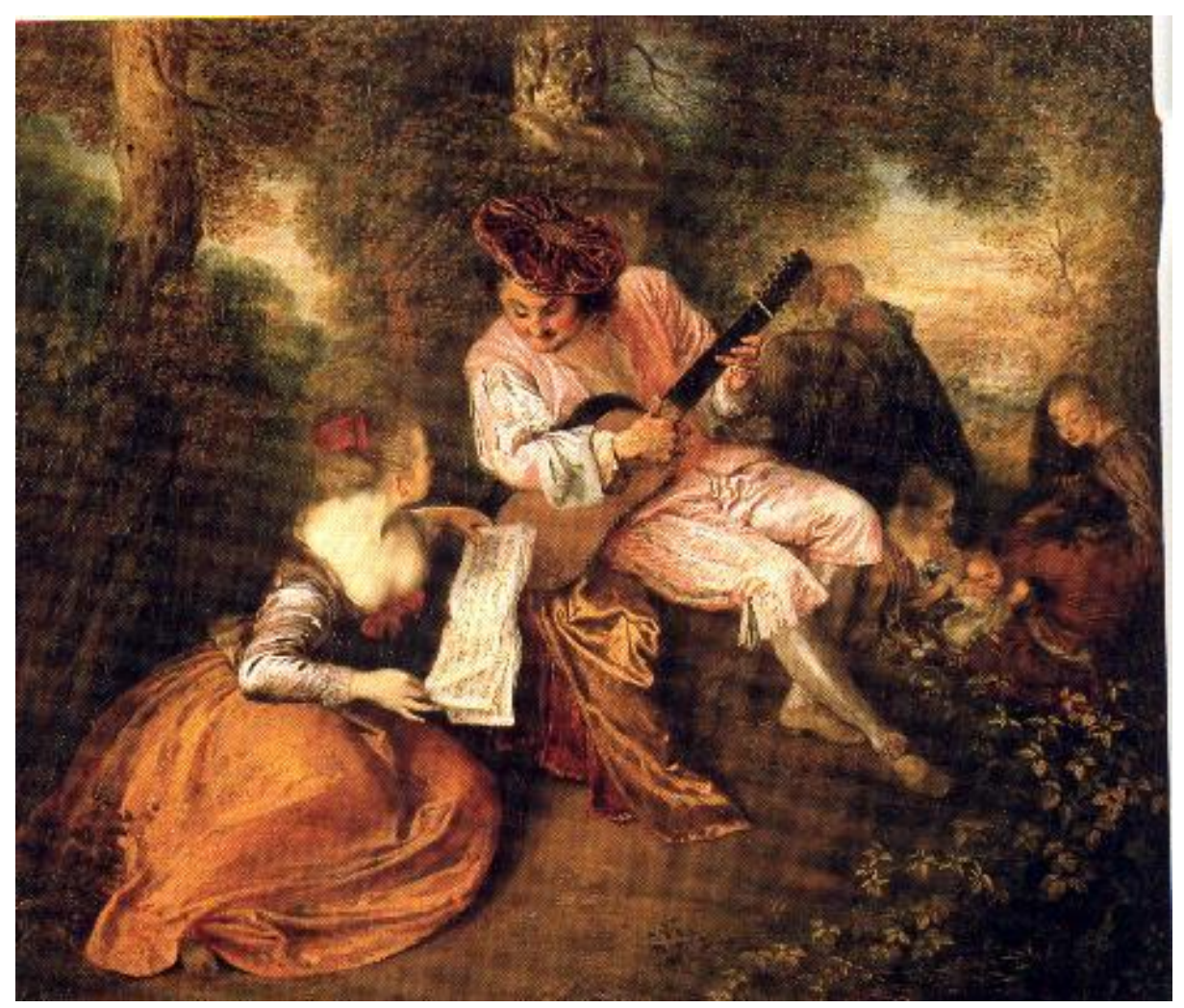

Jean-Antoine Watteau, Jogo do Amor, c. 1729, óleo sobre tela, (23,39 x 20,20 cm), National Gallery, Londres. Inglaterra

\footnotetext{
${ }^{92}$ Grand Dictionnaire historique de Moreri, Paris, 1725. In: ROSENBERG, Pierre. Vies anciennes de Watteau ... op. cit., p. 39

${ }^{93}$ Idem, "Os Prazes do Baile".

${ }^{94}$ Idem, "A Recreação Italiana".

${ }^{95}$ Idem, "O Prazer Pastoral"

${ }^{96}$ Idem, "Os Encantos da Vida"

${ }^{97}$ Idem, " Jogo do Amor"

${ }^{98}$ Idem, "Lição de Amor"
} 
O tema amoroso, em Watteau, sugere um sentimento sútil e menos frívolo: talvez, a doce melancolia. A obra do pintor não apresenta, em hipótese alguma, a ilustração da melancolia negra. De acordo com o Dicionário Universal relembra que "os poetas, os amantes entretêm sua melancolia na solidão". ${ }^{99}$ Um pequeno grupo de telas de Watteau corresponde a esta definição: a "categoria de personagens colocados no meio de uma paisagem que se compõe de figuras sozinhas e não unidas". ${ }^{100}$ A interpretação "docemente melancólica" que se propõe a esse tipo de composição é endossada pelos títulos propostos para duas gravuras, L'Amante inquiète ${ }^{101}$ e La Rêveuse ${ }^{102}$. Esses títulos remetem às ideias de "amante" e "sonho" - termos utilizados na definição da doce melancolia. Nessas obras, o contexto paisagístico é mundano e não mais mortífero e desolado como nas gravuras de Dürer. Se a gravura Melancolia I é considerada o paradigma da expressão nas obras, Watteau será o gênio melancólico entre o artistas. A doce melancolia francesa é o apanágio da elite, "galante", como na Inglaterra elisabetana onde já desabrochava o mito do "melancólico mundano". 103

Porém, Watteau ainda não expressa explicitamente em seus títulos a "doce melancolia". Isto somente aconteceria com uma obra apresentada entre 1757, uma pintura que propõe uma representação alegórica nova, desta delicada noção. Nesse ano, o jovem pintor Joseph-Marie Vien (1716-1809) apresenta a tela La Douce Mélancolie. ${ }^{104}$

${ }^{99}$ Dictionnaire universel françois et latin vulgairement appelé dictionnaire de Trévoux... nouvelle édition, ...op. cit.

${ }^{100}$ BOERLIN-BRODECK, Yvonne, “A figura numa paisagem”. In: Antoine Watteau (1684 - 1721). The painter, his age and his legend. Paris/Genebra, 1987, p.167-169. Nessa categoria, "a origem do topos de Watteau "melancólico" saído do Romantismo dos anos de 1830 a 1850". E, segundo ela, "é somente na segunda metade do século XVIII que o motivo da figura isolada, sentada pensativamente numa paisagem, torna-se uma figura pictórica da melancolia".

${ }^{101}$ DACIER, Émile; VUAFLART, Albert. Jean de Jullienne et les graveurs de Watteau au XVII siècle... op. cit., "O Amante Inquieto".

${ }^{102}$ Idem, "O Sonhador".

${ }^{103}$ PANOFSKY, Erwin.Saturn and Melancholy, op. cit., p. 380.

${ }^{104}$ FAROULT, Guilherme. "'A doce melancolia', segundo Watteau e Diderot - Representações melancólicas nas artes da França do século XVIII". In: GALERIES NATIONALES DU GRAND PALAIS, Mélancolie: Genie et Folie en Occident ...op. cit. 


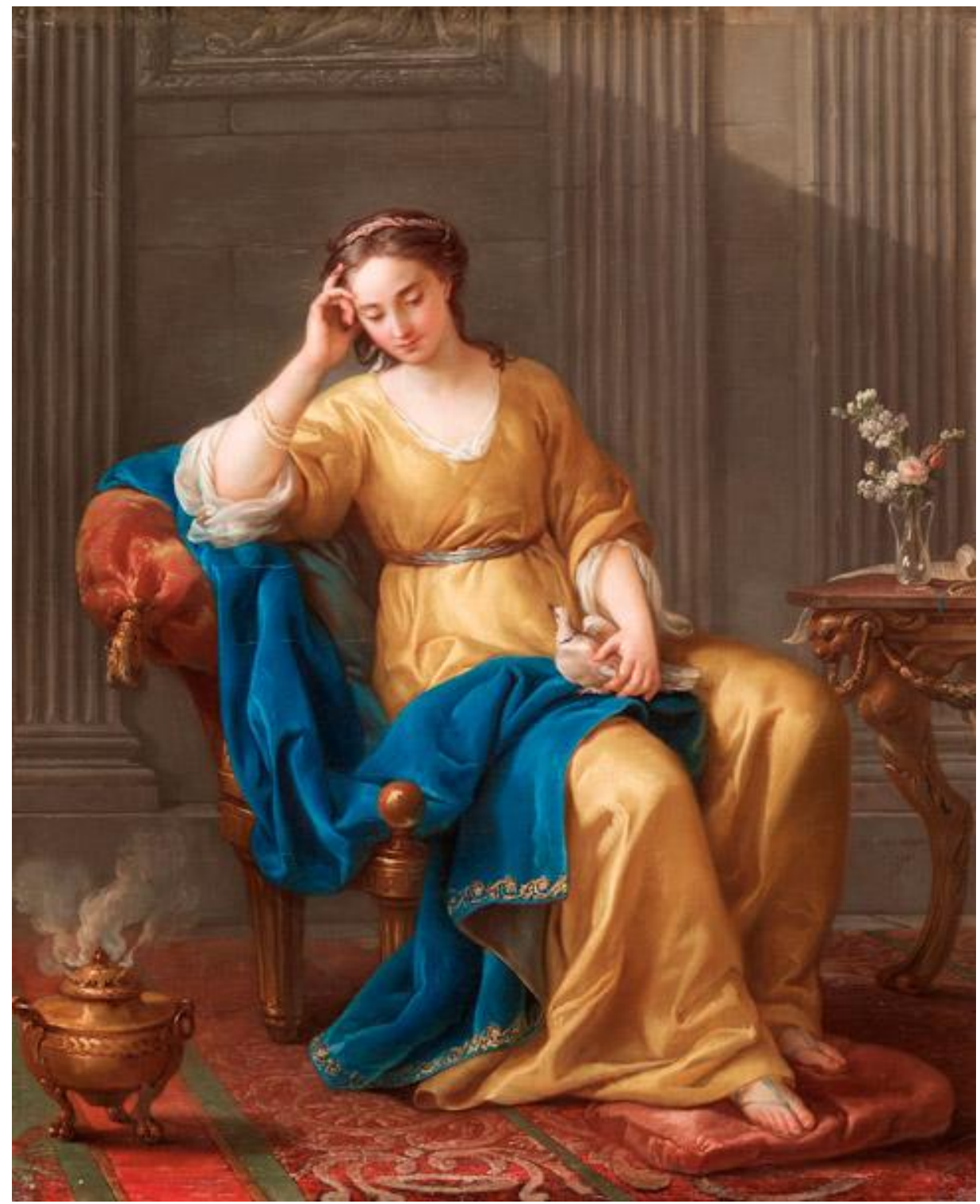

Joseph-Marie Vien. La Douce Mélancolie, óleo sobre tela (86,4 x 76,2 cm), 1756. () The Cleveland Museum of Art, Mr. and Mrs. William H. Marlatt Fund. EUA

Diderot, em sua crítica ao Salão de 1765, contesta o título da obra que julga adocicada:

(...) uma figura mal nomeada, é a Melancolia. Imaginar uma jovem de pé, o cotovelo apoiado numa coluna e tendo em sua mão uma pomba. Ela a olha, como ela a olha! Como uma pobre reclusa olharia através das barras de sua cela dois amantes carinhosos e apaixonados. Seu braço direito está pendido negligentemente (...). Acusam também os panos de não terem leveza na parte debaixo, perto das pernas. Que seja! ${ }^{105}$

${ }^{105}$ DIDEROT, Denis. Salão de 1765, edição de Else Marie Bukdahl e Annette Lorenceau, Paris, Hermann, 1984, p.297. 
Nesse mesmo ano de 1765 , em artigo atribuído a Diderot e consagrado à melancolia, publicado no décimo tombo da Enciclopédia, não se recorre à associação consagrada do termo "doce melancolia". Entretanto, a definição do pensador que, deliberadamente, interroga a noção filosoficamente, insiste na dimensão reflexiva e especulativa, integrando do mesmo modo um campo sentimental: "a Melancolia não é de forma alguma inimiga da volúpia"! ${ }^{106}$ E mais, o artigo anexa uma descrição da tela de Vien, elaborada por Diderot:

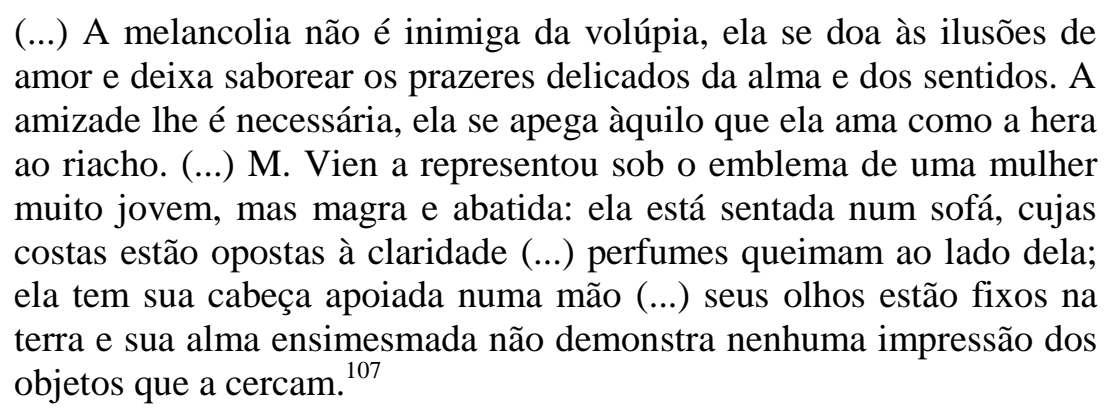

$\mathrm{O}$ artigo prossegue com uma definição negativa da "melancolia religiosa", "tristeza nascida da falsa ideia de que a religião prescreve os prazeres inocentes e que ela permite aos homens que se salvem pelo jejum, as lágrimas e a contrição do coração". ${ }^{108}$ Há, ainda, a associação estabelecida pelo autor entre "melancolia", "amizade" e "meditação". ${ }^{109}$ A "doce melancolia", ilustrada por Vien, está próxima da concepção dos enciclopedistas, mas destaca-se sutilmente. Ela ratifica, definitivamente, uma concepção positiva da melancolia, mas, voluntariamente, inclinase à meditação introspectiva e instrumental ao invés da depressão. Por um tempo, entre Watteau e Vien, a França busca uma definição - e uma ilustração - original, menos dramática, mais intensamente reflexiva, do gosto pelo melancólico. A França, "terra da razão", no século XVIII, examina o prazer cognitivo melancólico elaborado por

\footnotetext{
${ }^{106}$ Idem.

${ }^{107}$ Enciclopédia ou dicionário racional das ciências, das artes e dos ofícios, por uma sociedade de gente de letras, Neuchastel, tombo 10, 1765, p.307-308

${ }_{108}$ Enciclopédia..., p.308

${ }^{109}$ Idem.
} 
Milton. Porém, quando se aproxima o fim do Iluminismo, são propostas novas figurações melancólicas que serão muito mais lacrimais e, até mesmo, mórbidas. ${ }^{110}$

A partir desse momento, a "Idade da Razão" coloca as figuras melancólicas em descrédito. Os melancólicos são vistos como indivíduos autoindulgentes, ou seja, aqueles que não são disciplinados o bastante para dominar suas emoções. $\mathrm{O}$ "século das luzes" é também o da felicidade: a valorização do individualismo (independente de uma autoridade divina ou real) e a busca da felicidade e da alegria tornam-se objetivos socialmente apreciados. Nesse contexto, a melancolia é, novamente, estigmatizada e nesse intervalo de tempo, a "doença inglesa" teria encontrado, graças aos olhos dos franceses, um direcionamento ao spleen - vocábulo anglo-saxão incorporado à língua francesa por Baudelaire para designar o baço, órgão que os gregos relacionavam aos sintomas da melancolia. O spleen renova a concepção de que a constituição melancólica é inerente ao indivíduo e por esse motivo, dá vazão aos sentimentos mais intensos.

O sentimento melancólico toma impulso novamente com a emergência do Romanstimo. O florescimento dos ideais românticos, no século XIX, franqueia vigor à melancolia e à expressão artística. O sentimento é entendido como uma fonte de conhecimento - algo enobrecedor. As poéticas românticas mesclam tristeza, prazer e beleza. A beleza, na tristeza melancólica dos românticos, reside no apego pelos aspectos exóticos, selvagens e da natureza. Exaltam sensações extremas, paraísos construídos por intermédio dos homens e a natureza em seu elemento mais bruto. Segundo essa visão, a melancolia é atributo de valor: seu estado é apreciado, remetendo-se diretamente a retomada da tese aristotélica.

\footnotetext{
${ }^{110}$ De forma significativa, o título das duas pinturas, representando La Mélancolie, expostas no Salão de 1801 por Constance Charpentier (1767-1849) e por Françoise André Vincent (1746-1816), abandonam o doce objetivo. FAROULT, Guilherme. "'A doce melancolia', segundo Watteau e Diderot - Representações melancólicas nas artes da França do século XVIII". In: GALERIES NATIONALES DU GRAND PALAIS, Mélancolie: Genie et Folie en Occident ...op. cit.
} 
O retorno à natureza e à essência humana fornece as bases teóricas do movimento Sturm und Drang (tempestade e ímpeto), que no seu âmago reflete a luta milenar do homem "do Norte" contra a natureza inimiga, acentuando o caráter mítico e espiritualista dessa luta e buscando sua presença nas sagas populares. ${ }^{111}$ Mergulhados em sentimentalismo, Goethe (Die Leiden des Jungen Werther - O Sofrimento do Jovem Werther, 1774), Schiller (An die Freude - Ode à Alegria, 1785) e Herder (Auszug aus einem Briefwechsel über Ossian und die Lieder alter Völker - Extrato da correspondência sobre Ossian e as canções dos povos antigos, 1773), propagam novos ideais estéticos que expressam não só o sentimento como também o pensamento romântico, fundidos na ironia e na autorreflexão. Do mesmo modo, destacam-se, na França, Stendhal, Hugo e Musset - poetas que inspiram a tendência onírica de Giorgio De Chirico. Na Itália, Giacomo Leopardi (1798-1837) - autor que serve de referências para muitas obras de De Chirico, escreve “(...) o destino não legou à nossa raça/nenhum dom exceto o de morrer" ${ }^{112}$, monstrando uma noção niilista de futilidade das coisas, uma sensação melancólica presente às coisas do mundo que filtra todos os outros sentimentos.

Some-se, o foco no individualismo que traz consigo o culto do egocentrismo, vazado de melancolia, pessimismo e apego ao intimismo. À época, o romantismo torna-se crítica à perda das perspectivas correlacionadas à razão. Goethe transforma-se numa forte influência literária. Basta dizer que seu livro de juventude Os Sofrimentos do Jovem Werther, de intenso dramatismo, tratando de um amor impossível, uma das peças mais típicas do movimento Sturm und Drang, provoca uma onda de suicídios quando publicado na Alemanha. ${ }^{113}$ Outros filósofos como Johann Gottlieb Fichte e Friedrich Schelling, junto com literatos como Schiller, fizeram das terras germânicas um centro do primeiro romantismo, que trata, sobretudo, de temas tipicamente

\footnotetext{
${ }^{111}$ ARGAN, Giulio Carlo. Arte Moderna. São Paulo: Companhia das Letras, 1992, p. 169.

${ }^{112}$ APUD. SOLOMON, Andrew. O Demônio do Meio-Dia: Uma Anatomia da Depressão ...op. cit., p. 292.

${ }^{113}$ Em Wether, Goethe narra a impossibilidade da entrada no verdadeiro sublime, desse modo, a melancolia seria a verdade. Idem, p. 293.
} 
regionais, incluindo sua paisagem, seu folclore, a cultura gótica e a mitologia, sendo uma inspiração para as artes.

Nas artes, o sentimento romântico expressa a elevada e sublime melancolia, a solidão, a angústia existencial do homem diante de uma natureza mais misteriosa e simbólica do que adversa. A relação com a natureza é quase sempre de atração, portanto, não há a exclusão do isolamento nostálgico do homem “civilizado" frente à natureza. ${ }^{114}$ As referências estéticas partem dos antigos mestres, tal como Dürer, as quais tentam recuperar o sentido religioso da realidade cercado por símbolos. ${ }^{115} \mathrm{~A}$ influência de Arnold Böcklin (1827-1901) inclui procedimentos de tipo acadêmiconaturalista um alegorismo literário e um impetuoso realismo. ${ }^{116}$ A esse repertório aliase a produção de Max Klinger (1857-1920) que ocasiona contatos mais fecundos entre Munique, Roma e Paris no período. ${ }^{117}$

${ }_{115}^{114}$ ARGAN, Giulio Carlo. Arte Moderna...op.cit., p. 172.

${ }^{116}$ Artisticamente influenciado pelas obras de Thomas Couture e de Camille Corot, quando da sua visita à cidade de Paris, em 1848, Arnold Böcklin, dirige-se posteriormente para Roma, entre os anos de 1850 e 1857, onde, à semelhança de outros artistas do seu tempo, faz cópias de obras da Antiguidade Clássica. Do conjunto de obras que observa, copia e estuda na Itália os trabalhos de Rafael. Também, retira elementos das naturezas presentes nas telas de pintores quinhentistas e seiscentistas do Norte da Europa, como Salomon von Ruysdael, Albrecht Dürer e Mateus Grünewald, que alia a temáticas próprias do Romantismo Alemão. Esses aspectos, reforçados pelos elementos que Böcklin retira do movimento simbolista francês, contribuem para a influência exercida sobre pintores do Expressionismo e do Surrealismo. Arnold Böcklin. In Infopédia. Porto: Porto Editora, 2003-2010. Disponível na www: <URL: http://www.infopedia.pt/\$arnold-bocklin>. Acesso em 02 de dezembro de 2010.

${ }^{117}$ Max Klinger inicia sua formação artística em 1874, em Karlsruhe, continuando em Berlim, Munique e Paris. Vive em Roma, entre os anos de 1888 e 1893, especialmente influenciado pela trabalho de Arnold Böcklin. Para Klinger, arte significa preservar o "mundo exterior". A fantasia pode ser expressa apenas em desenho e gravura. Nesse sentido Klinger trabalha para unir o mundo exterior e interior, como igualmente inspirado, os vê como opostos. www.max-klinger.com/. Acesso em 23 de dezembro de 2010. 


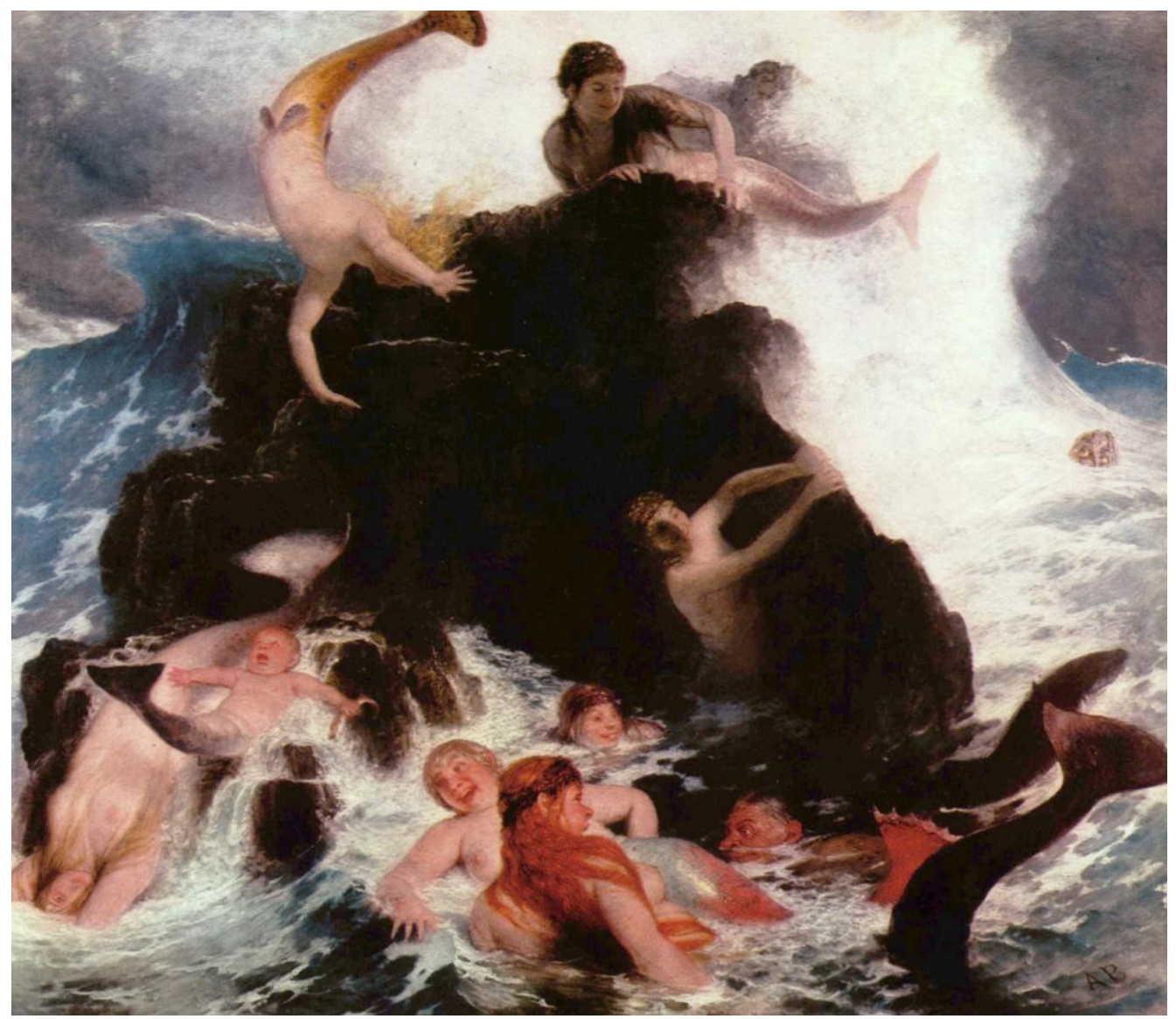

Arnold Böcklin, Das Spiel der Najaden, óleo sobre tela (151 x 176 cm), 1886 Kunstmuseum, Basileia. Suíça

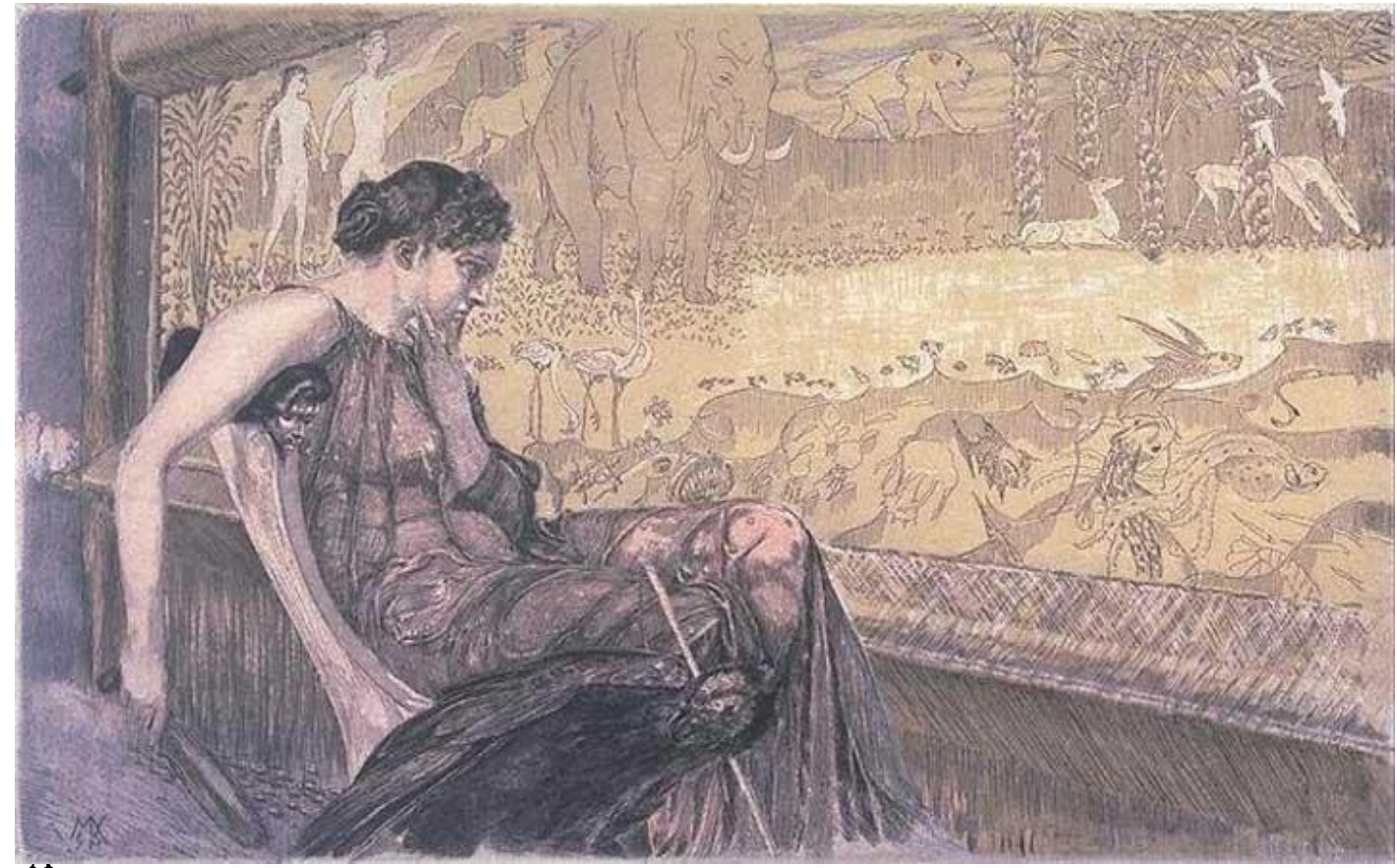

Max Klinger, Penelope weaving a shroud for Laertes her father-in-law while she awaits the return of her husband, gravura, (46 x $61 \mathrm{~cm}), 1895$, Munique. Alemanha 
De Chirico é profundamente influenciado por essa vertente do Romantismo e decorre daí, sua expressão do sentimento. O estudo da longa tradição da melancolia (desde seus aspectos médico-filosóficos), por intermédio de Böcklin e Klinger, chegam ao jovem De Chirico, como uma estética construída do sentimento com elementos próprios. A herança grega, renascentista e a constituição da "doce melancolia" formam o universo cognitivo do jovem pintor.

O jovem De Chirico está em Munique, em 1905. Lá descobre a obra de Arnold Böcklin, que o motiva bastante, quase tanto quanto Max Klinger. De Chirico discerne nas paisagens povoadas de personagens mitológicos de Böcklin a faculdade excepcional de aliar elementos naturais e sobrenaturais; o cotidiano e o mítico; a tradição e a inovação - fatores que De Chirico encontra, também, nas gravuras desse artista. De Chirico passa horas estudando as gravuras de Klinger, fascinado pela mistura enigmática de fatores autobiográficos e fantásticos, cotidianos e míticos, reais e irreais. $^{118}$

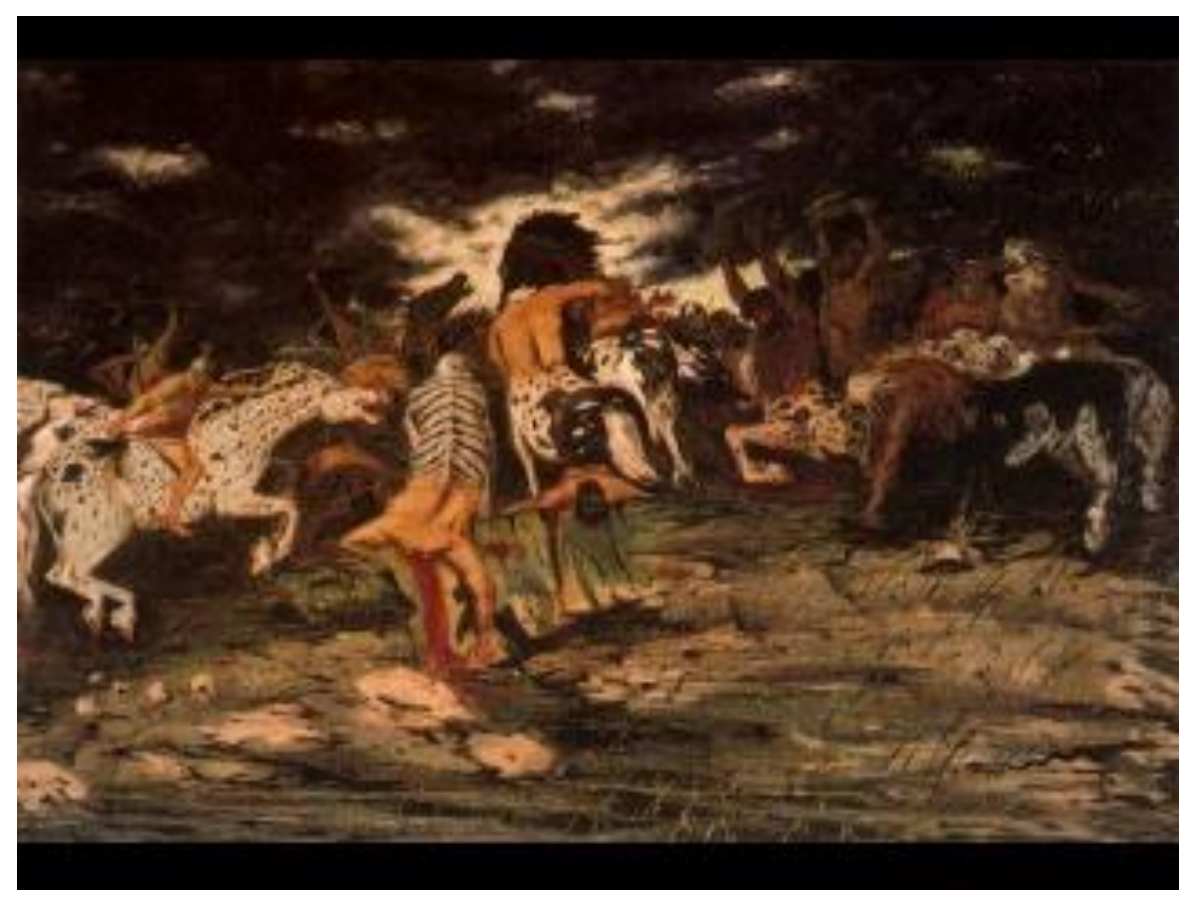

Giorgio De Chirico, A Batalha dos Centauros, óleo sobre tela (75 x $110 \mathrm{~cm}), 1909$. Galleria Nazionale d’Arte Moderna, Roma. Itália

118 HOLZHEY, M. De Chirico (1888-1978): Le mythe moderne. Paris: Taschen, 2005, p. 6 e seguintes. 
A tela Enigma do Oráculo, obra produzida em 1909, é inspirada no episódio de Ulisses e Calypso do Livro V da Odisseia ${ }^{119}$ e apresenta correlações entre o artista e a figura pensativa à esquerda (transposta de Ulisses e Calypso de Böcklin, 1883). Sintetiza a completa tradição vinda da pintura romântica que possui como tema central uma figura solitária, contemplando sua relação com a Natureza e com o mundo. ${ }^{120} \mathrm{~A}$ figura de Ulisses, do filósofo-profeta, representa o próprio pintor ou, de forma indireta, seu pai.Os termos nos quais descreve essa obra, no entanto, não deixam dúvidas que as pinturas resultam a reflexão mais acurada sobre o trabalho de Böcklin. ${ }^{121}$ De Chirico, sobretudo, descobre a filosofia de Arthur Schopenhauer ${ }^{122}$ e Friedrick Nietzsche.

Os conceitos de Nietzsche, tais como, o valor da surpresa transmitida pela obra de arte, a angústia do labirinto, o significado da stimmung ${ }^{123}$ e principalmente, o enigma, formam um universo a ser explorado pelo jovem. O método nietzchiano implica em eliminar da arte tudo o que se mostrar como "verdade incontestável". Suprime o homem como guia ou como meio de expressar símbolo, sensação ou pensamento. Liberta do antropomorfismo e visualiza o homem em sua qualidade de coisa. ${ }^{124}$ No pensamento de Schopenhauer, o artista examina o valor da originalidade, a revalorização da revelação e a meditação sobre a existência.

${ }^{119}$ Ulisses aprisionado pelo encanto de Calipso permanece refém em sua ilha. Comovida por essa situação, Athena pede a Zeus para libertá-lo e mandá-lo de volta para a casa. Zeus dá ordens a Hermes para ir até Calipso e manda-la libertar Ulisses e ajudá-lo a encontrar Skheria, uma ilha próxima a Ítaca. Calipso cumpre as ordens de Zeus, mas alerta Ulisses sobre possíveis interferências de Poseidon. A medida em que Ulisses se aproxima das imediações de Skeria, Poseidon ataca com ondas e ventos. Com a ajuda de Ino, Athena e o deus das correntezas, Ulisses nada para a terra e cai desacordado sobre um monte de folhas macias. Livro $\mathrm{V}$ da Odisséia.

${ }^{120}$ De Chirico produz $O$ Enigma do Oráculo em Milão, porém, a obra surge, como ideia, em Florença, talvez, no fim de setembro de 1909. Em escrito datado de 1910, De Chirico faz referência a um grupo de novos trabalhos que executa durante o verão anterior. BARBOSA, Paulo Roberto Amaral. Giorgio De Chirico no Acervo MAC USP ... op.cit., p. 53 e seguintes.

121 BALDACCI, Paolo. De Chirico.The Metaphysical Period (1888-1919). Boston/New York/Toronto/London: A Bulfinch Press Book/Little/Brown and Company, 1997, p. 86 e seguintes

${ }^{122}$ Artur Schopenhauer não acredita que a dor fosse de modo algum enobrecedora e, mesmo assim, era irônico e epigramático. Para o filósofo, a continuidade da vida e da história é mais absurda do que trágica. SOLOMON, Andrew. O Demônio do Meio-Dia: uma anatomia da depressão...op.cit., p. 294.

${ }^{123}$ Stimmung é, em resumo, a atmosfera, a sensação que produz cada ambiente.

${ }^{124}$ NIETZSCHE, Frederic. Obras Completas. São Paulo: Abril Cultural, 1983. 


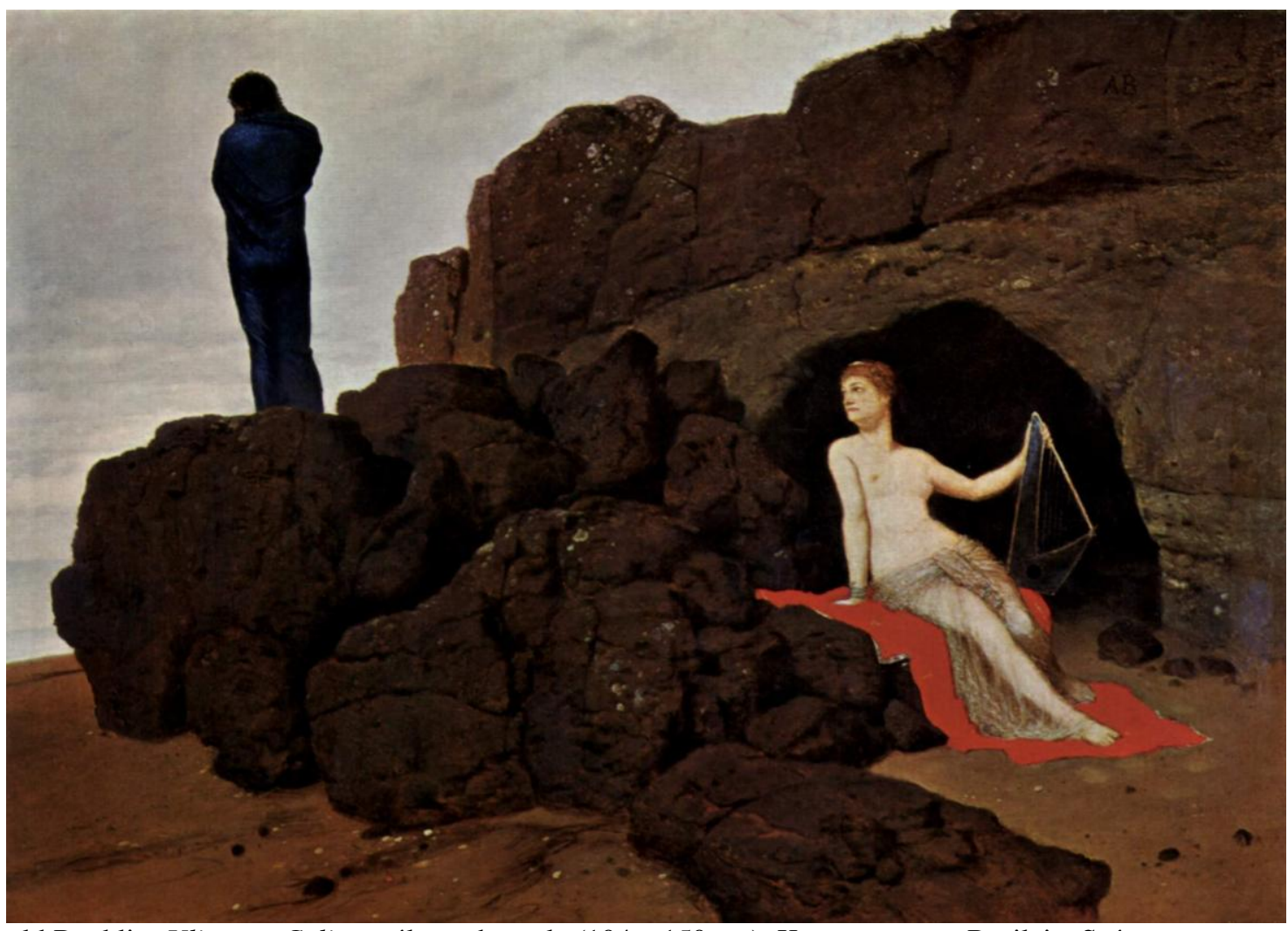

Arnold Böcklin, Ulisses e Calipso, óleo sobre tela (104 x 150 cm), Kunstmuseum, Basileia. Suíça

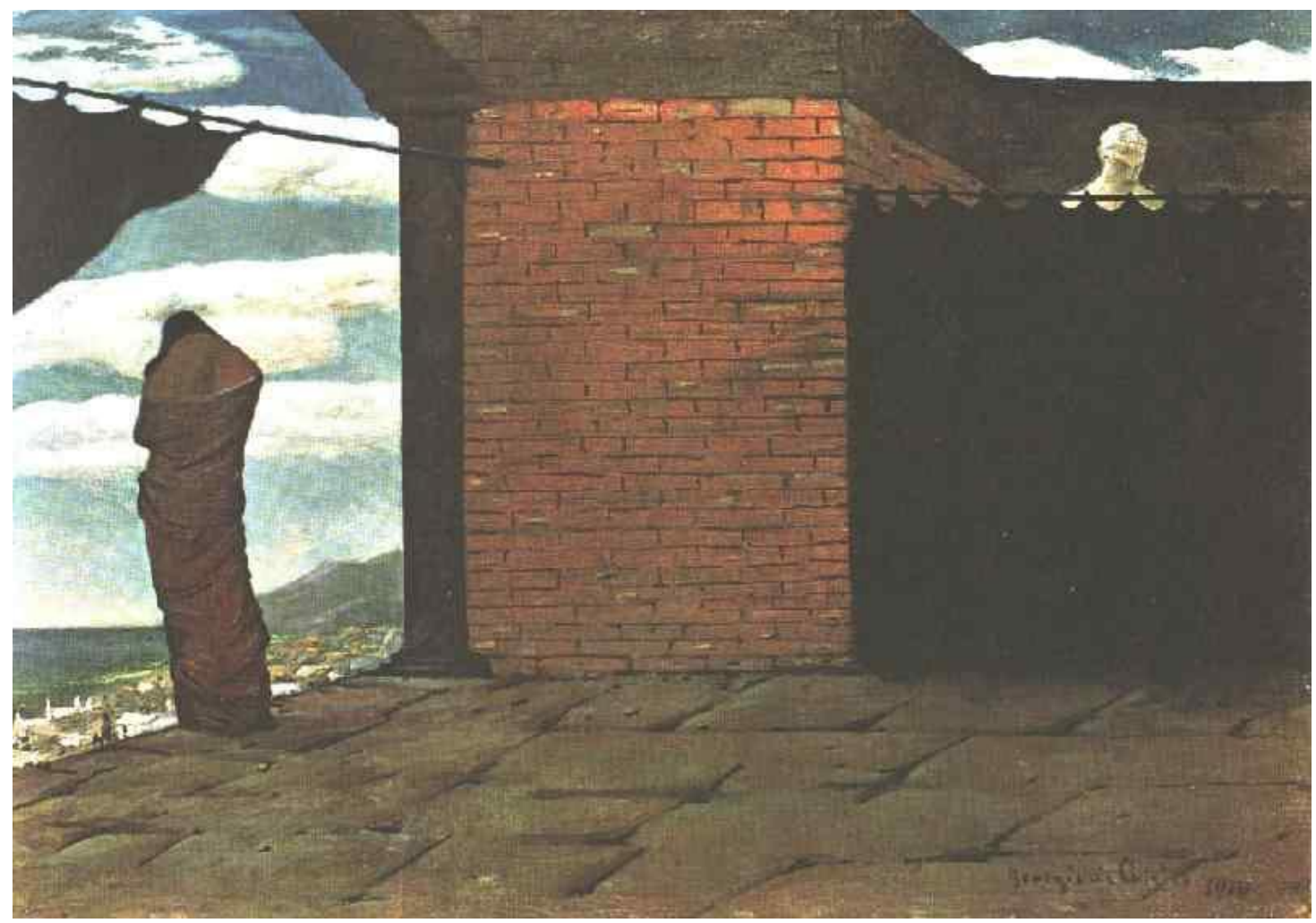

Giorgio De Chirico, O Enigma do Oráculo, óleo sobre tela, (42 x $61 \mathrm{~cm}), 1909$. Coleção Particular, Turim. Itália. 
(...) todo o resto que leu Nietzsche, não compreendeu em que consistia a verdadeira novidade descoberta pelo filósofo. Tal novidade é uma estranha e profunda poesia, infinitamente misteriosa e solitária, baseada na stimmung (uso esta palavra alemã muito eficaz e que em italiano poderia ser traduzida como: atmosfera no senso moral) baseada na stimmung de uma tarde de outono, quando o céu é claro e as sombras são mais longas que no verão, pois o sol está mais baixo. ${ }^{125}$

No tema do Enigma do Oráculo a atmosfera outonal derivada da leitura de Nietzsche, principalmente Ecce Homo e Assim Falava Zarathustra, que poderia ser traduzida em resumo pelo céu outonal que tipificam outros trabalhos metafísicos, está ausente. Um exame mais apurado poderia afirmar que a influência de Nietzsche não existe. Por que, então, De Chirico ostenta essa tela com o título nietzchiano de "enigma"? 126

O fato é que De Chirico lê Nietzsche e executa pinturas inspiradas em recursos literários ainda atrelados a uma matriz romântica. Embora alguns de seus trabalhos desse período, permaneçam ligados ao passado e expressem uma vaga sensação de melancolia, outros estão carregados de um poder simbólico e evocativo que permite ao espectador transcender através da completa transfiguração dos recursos literários no tema da melancolia-contemplativa. O Enigma do Oráculo compreende a definição que o coloca como "fase bockliniana", documentada em carta a um amigo em 1910, onde e quando De Chirico traça um paralelo entre "o mais profundo" pintor e o "mais profundo" filósofo: Böcklin e Nietzsche respectivamente. ${ }^{127}$ A principal virtude de Böcklin para De Chirico consiste em sua capacidade em diluir o tempo linear pela composição dos mitos antigos em uma espécie de eterno presente, dotando a figura

\footnotetext{
${ }^{125}$ DE CHIRICO, Giorgio. Memorie della mia vitta. Roma: Rizolli, 1962

${ }^{126}$ A leitura desses livros causa uma transformação radical na obra do artista. O que o fascina de imediato é o poder e a eloquência da poesia de Nietzsche. $\mathrm{O}$ amor pelo enigma reúne filósofo e artista. De Chirico adota o conceito nietzsciano sobre a morte de Deus, obrigando a considerar, em sua obra, a relatividade dos fenômenos do mundo, dos produtos da lógica humana e do postulado de uma verdade definitiva - a "morte de Deus" leva o homem à melancolia. Ao seguir esses parâmetros, pondera-se que não há uma verdade única, a pintura metafísica não deve procurar o aspecto enigmático das manifestações do mundo além das coisas, mas no interior destas. HOLZHEY, M. De Chirico (1888-1978): Le mythe moderne... op. cit., p. 12

${ }^{127}$ BALDACCI, Paolo. De Chirico.The Metaphysical Period (1888-1919)...op.cit.,p. 86
} 
mitológica com aspecto misterioso de realidade contemporânea. $\mathrm{Na}$ técnica de deslocamento de Böcklin (na qual, o mito se faz presente na atualidade), De Chirico vê um efeito similar àquele consolidado na prosa de Nietzsche. ${ }^{128}$

O Enigma de Uma Tarde de Outono, produzido em novembro de 1909, representa a primeira "revelação" de De Chirico, ocorrida em outubro do mesmo ano, ocasião de sua estada em Florença e, mais tarde, descrita em célebre passagem em Paris. ${ }^{129}$ A figura de Ulisses, o herói-pensador em $O$ Enigma do Oráculo, é substituída pela do poeta-pensador. Os demais elementos da composição dividem a cena em partes distintas: um muro obscurece o horizonte e dois personagens que dão à atmosfera reminiscências poéticas existentes na obra de Giacomo Leopardi. ${ }^{130}$

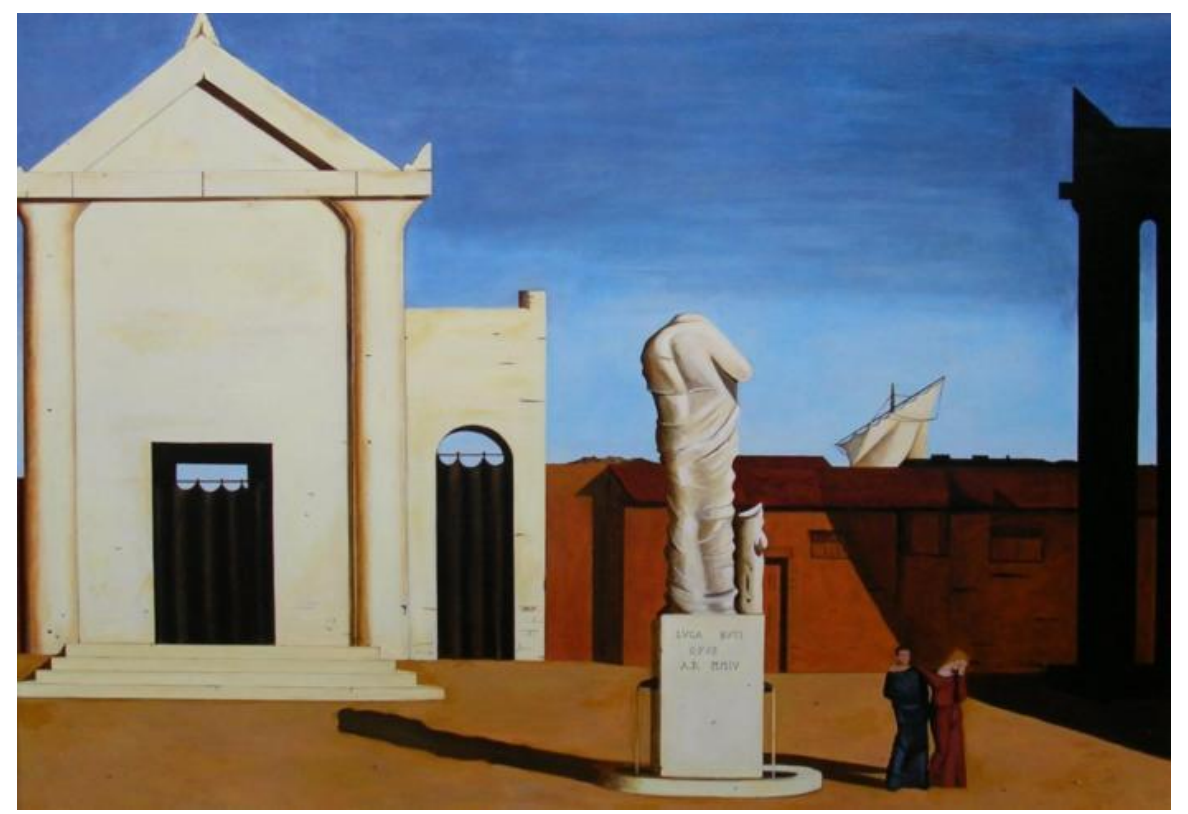

Giorgio De Chirico

O Enigma de Uma Tarde de Outono, óleo sobre tela, (1006 x $152 \mathrm{~cm}), 1910$. Coleção particular, Buenos Aires. Argentina.

${ }^{128}$ Idem.

${ }^{129}$ DE CHIRICO, Giorgio. "Meditações de um Pintor", 1912. In: CHIPP, H.B. Teorias da Arte Moderna, São Paulo: Martins Fontes, 1996, p. 403.

${ }^{130}$ De Chirico agrupa genericamente obras realizadas durante o verão de 1910. Observa-se que o artista não as considera, ainda, como "revelações" que seriam executadas posteriormente. Pondera-se que os Enigmas somente puderam ser concebidos após a leitura de Nietzsche e as viagens a Roma e a Florença, lugares que impressionaram o artista pela configuração arquitetônica. Em sua avaliação sobre a "revelação" que se lhe apresenta na Piazza Santa Croce, em Florença, De Chirico explica que a razão que escolhe para chamar sua pintura de "enigmas" reside no fato de representarem uma sensação inexplicável - um momento de integração total entre o sujeito e o mundo ao seu redor - algo permeado pela intuição. De Chirico afirma: "Um dos dons desconcertantes que subsiste de tempos arcaicos é a intuição. Ela existirá sempre. É de alguma forma uma prova perpétua do non-sense do Universo. Idem. 
A atmosfera leopardiana, despertada em O Enigma de Uma Tarde de Outono, atribui um efeito espacial desestabilizante ao plano da obra. Na maioria das composições das telas metafísicas de De Chirico, encontram-se as ideias do poeta Giacomo Leopardi, cuja obra De Chirico aprecia. ${ }^{131}$ Neste cenário da produção artística de De Chirico, percebe-se a "teoria do indefinido infinito", elaborada por Leopardi, na qual o escritor anuncia a descoberta fundamental de que tudo que é dissimulado ao olhar, parece mais poético e mais impressionante do que o que é diretamente representado - De Chirico é seguidor dessa premissa.

A análise do conjunto das obras que compõem a Série dos Enigmas delineia a descoberta do processo criativo de De Chirico. Nesse processo, é perceptível o emprego dos conceitos filosóficos que o artista preza em Nietzsche e os suportes estéticos encontrados em Böcklin e Klinger para elaborar uma poética baseada no sentimento melancólico-romântico repleto de elementos compositivos carregados de simbologia. ${ }^{132}$ Esses elementos dão coerência à Série dos Enigmas e tornam possível aprofundar a discussão sobre as interações entre elementos clássicos e modernos na produção artística de De Chirico. ${ }^{133}$ Dessa forma, a investigação dirige-se para a

131 BALDACCI, Paolo. De Chirico. The Metaphysical Period (1888-1919) ... op. cit., p. 86 e seguintes.

${ }^{132}$ Idem.

${ }^{133}$ Conforme identificadas por Maurizio Faggiollo d'Arco, consideram-se as seguintes fases de De Chirico: 1910/15 - Florença e Paris, os princípios da estética metafísica; 1915/1918 - Ferrara, afirmação da Metafísica; 1918/1922 - período clássico, de Valori Plastici, retorno à pintura; 1923/1924 - período romântico; 1925 - crise depois do Surrealismo; 1926/1930 - novas mitologias; 1930/1934 - período renoiriano, clássico e monumentalista; novas visões; 1936/1938 - América; 1937/1948 - barroco, romântico; 1948/1978 - período neometafísico. Giorgio De Chirico produz romances, poesias, ensaios críticos, livros de memórias. Colabora com revistas como Valori Plastici, La Ronda e Convengo e publica em 1929 Hebdomeros, romance autobiográfico, considerado uma obra-prima da literatura surrealista. $\mathrm{O}$ artista realiza figurinos e cenários para a comédia coreografada La Giara, de Alfredo Casella, atividade que retoma nos anos de 1960. Em 1930 ilustra Calligrammas, de Apollinaire; entre 1936 e 1938 ilustra capas de Vogue e Hoper's Bazaar. Desenha móveis para a mostra Four Rooms Designed for Paintings em sua estada em Nova York. A partir de 1936, interessase pela escultura em terracota, recriando, em volume alguns de seus personagens preferidos: Heitor e Andrômeca, Hipólito e seu cavalo, Os Arqueólogos. Posteriormente retoma a escultura em bronze com seus temas recorrentes, acrescidos dos cavalos clássicos. Em seguida, De Chirico se dedica à criação dos múltiplos em bronze e prata e escultura/joias em prata. FAGGIOLO, Maurizio. Giorgio De Chirico Il Tempo di Apollinaire - Paris 1911/1915: Roma: De Luca Editore, 1981. 
leitura do moderno - o tempo de De Chirico. O estado melancólico do jovem artista, após a perda do pai e os constantes deslocamentos da família pode ter influenciado seu repertório estético? A Guerra e seus acontecimentos correlatos seriam "a peste" dos tempos modernos? A presença da máquina e o novo mundo que emerge da segunda revolução industrial, instigam o aritsta a um embate entre o passado e o futuro? E quais são suas escolhas e resposta às emergências de sua época?

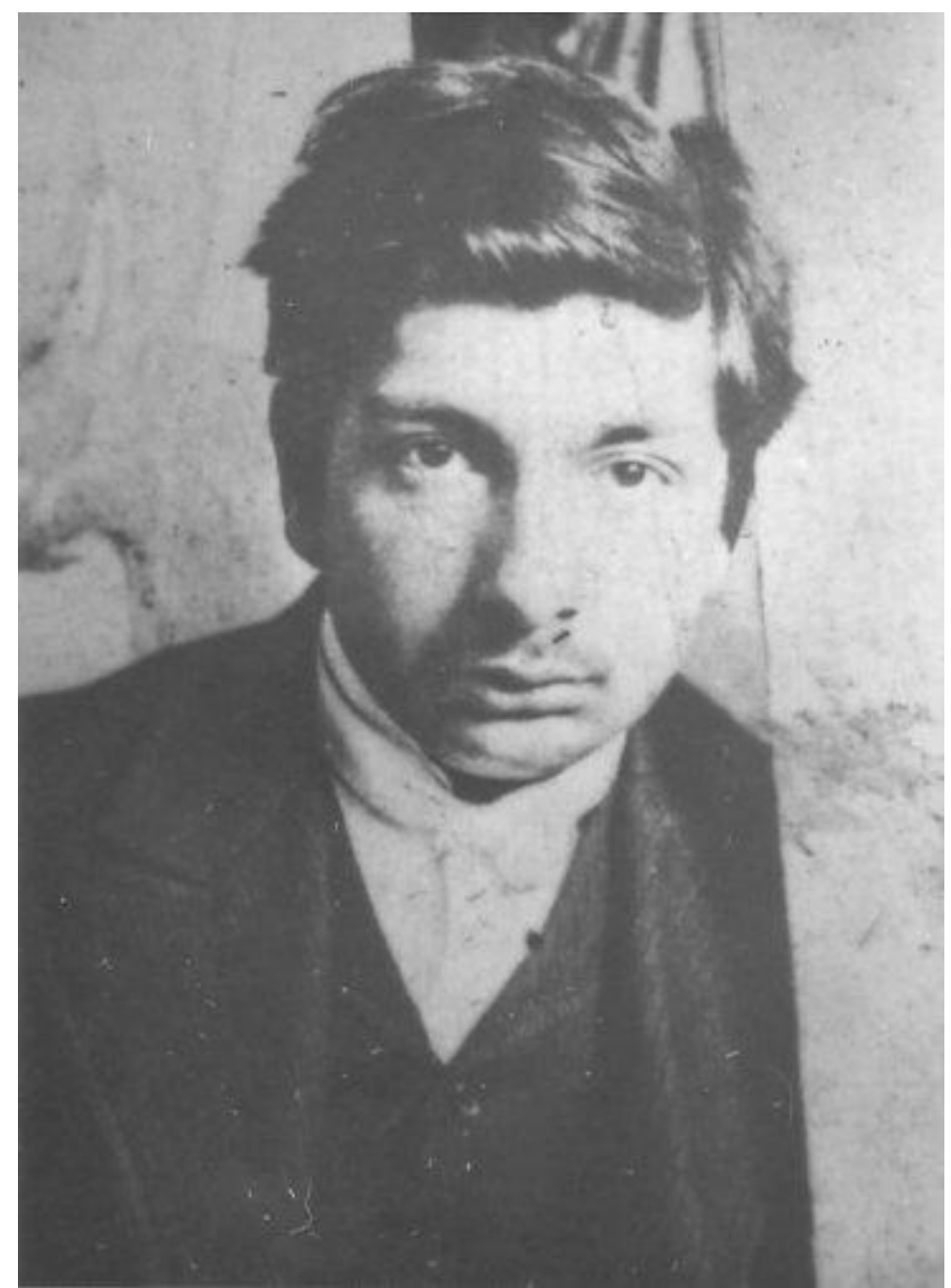

Giorgio De Chirico em Munique, (fotografia), 1908. 


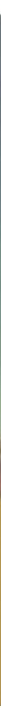

LEITURAS DA MODERNIDADE 


\section{O Estado Melancólico}

A morte do pai de De Chirico, em 1905, provoca uma imensa transformação na sua vida: o luto pela perda agrega-se aos deslocamentos da família que já são frequentes devido à profissão do pai (engenheiro de estradas de ferro). ${ }^{1}$ A presença paterna na personalidade de De Chirico é bastante forte. $\mathrm{O}$ artista descreve seu pai como um gentiluomo, dotado de diversas capacidades e virtudes: engenheiro brilhante; desenha; aprecia música; é cavalerizzo-montador e, principalmente, dono de um senso de justiça aguçado. ${ }^{2}$ Com a perda do pai, a mãe de De Chirico resolve sair da Grécia e seguir para Munique - local onde julga dar continuidade à formação intelectual de seus filhos. A educação de De Chirico e seu irmão, Andrea, é severa e conservadora, mas há a permissão para o desenvolvimento de atividades ligadas aos seus interesses.

À época, Munique é pólo cultural efervescente, mais propício para a formação de De Chirico e Andrea. Contudo, entre Atenas e Munique, a família faz uma pausa em Florença, onde permanece até 1906. É uma temporada de inúmeras visitas a museus e galerias, entre elas, a Galleria Degli Uffizi, na qual as obras dos grandes artistas italianos como Tintoretto, Ticiano, Veronese e, sobretudo, de Segantini e de Previati, comovem e impressionam De Chirico.

(...) havia compreendido, não menos do que compreendo agora, a profundidade e a metafísica de obras de Böcklin, Klinger, Segantini, Previati, de todos aqueles os quais, pintando,

\footnotetext{
${ }^{1}$ Em fins do século XIX, Sigmund Freud, classifica o processo melancólico como algo que se assemelha ao luto, mas sem haver necessariamente uma perda (senão uma perda narcisista). Para Freud, os traços mentais distintivos da melancolia são um desânimo profundamente penoso, a cessação de interesse pelo mundo externo, a perda da capacidade de amar, a inibição de toda e qualquer atividade, e uma diminuição dos sentimentos de autoestima a ponto de encontrar expressão em autorrecriminação e autoenvelhecimento, culminando numa expectativa delirante de punição. Esse quadro torna-se um pouco mais inteligível quando se leva em conta que, com uma única exceção, os mesmos traços são encontrados no luto. A perturbação da autoestima está ausente no luto; afora isso, porém, as características são as mesmas. FREUD, S. Luto e melancolia, Edição Standard brasileira (SB), v. XIV, p.276.

${ }^{2}$ DE CHIRICO, Giorgio. Memorie della mia vitta. Roma: Rizolli, 1962, p. 32 e seguintes.
} 
independentemente da qualidade de sua pintura, narraram algo de poético, de curioso, de estranho, de surpreendente. ${ }^{3}$

Em Munique, De Chirico se reveza entre as aulas sistemáticas da Academia Real de Belas-Artes e o estudo de pintura antiga na Pinacoteca. Acompanha seu irmão Andrea (que estuda música) à residência do compositor Max Reger. ${ }^{4}$ Os espaços alargados e pequenos acostamentos da cidade neoclássica influenciam seu estado de ânimo, cada vez mais nostálgico. Passeia por Munique contemplando a obra de artistas como Böcklin, Lenbach, Dürer e Rubens. ${ }^{5}$ Inicia uma temporada de muita produção. De Chirico elabora suas primeiras telas, explorando temas, tais como, cidades, marinhas, centauros e sereias. Suas telas apresentam inspiração em Böcklin e uma atmosfera profundamente romântica. Segundo Maurizio Fagiolo Dell'arco, é neste momento que realiza seu primeiro autorretrato, no qual surge a temática que o acompanha em sua produção artística: a melancolia. Sentimento expresso no modo em que a cabeça posa sobre o braço, numa referência a um retrato de Nietzsche.

Por volta de 1910, Andrea se estabelece em Paris. De Chirico e a mãe retornam a Florença. As crises de melancolia, as cólicas intestinais que acompanham a vida do artista começam a acentuar-se, mas, no entanto, sua produção intensifica-se. É o fim do período bockliniano e o início da melancolia das belas tardes de outono. As telas Enigma do Oráculo (1909) e Enigma de uma Tarde de Outono (1909) são o prelúdio da série de praças italianas e do sentimento melancólico que se manifesta em muitos dos seus trabalhos. O relato do artista sobre como concebe Enigma de uma Tarde de Outono fornece elementos para a compreensão da série Enigmas e de como o artista vive o sentimento melancólico (especialmente, pelo víeis fisiológico). De Chirico inicia com a lembrança do seu estado de ânimo e como essa condição direciona o olhar:

\footnotetext{
${ }^{3}$ Idem.

${ }^{4}$ HOLZHEY, M. De Chirico (1888-1978): Le mythe moderne...op.cit., p. 6 e seguintes

${ }^{5}$ DE CHIRICO, Giorgio. Memorie della mia vitta ... op. cit.
} 
Numa radiosa tarde outonal eu estava sentado num banco no meio da Piazza Santa Croce, em Florença. Não era, claro, a primeira vez que via aquela praça. Acabara de sair de uma prolongada e dolorosa enfermidade intestinal e achava-me num estado de sensibilidade quase mórbida (...). No meio da praça ergue-se uma estátua de Dante envolto num longo manto, segurando suas obras junto do corpo, a cabeça coroada de louros inclinada pensativamente para a terra (...). ${ }^{6}$

E continua com a "revelação" da obra:

O sol de outono, cálido e pouco suave, iluminava a estátua e a fachada da igreja. Tive então a estranha impressão de que estava olhando para todas aquelas coisas pela primeira vez e a composição do meu quadro veio à mente. Agora, todas as vezes que olho para este quadro, revejo aquele momento. Não obstante, ele constitui um enigma para mim, pois é inexplicável. E gosto também de chamar enigma à obra que dele nasceu.

Para o artista, uma obra de arte somente pode nascer da "revelação". Nessa concepção de objeto artístico, De Chirico baseia-se em Schopenhauer e, particularmente, no argumento de que para se ter ideias originais, extraordinárias e imortais, é preciso isolamento do mundo por alguns momentos, tão completamente que os fatos comuns apresentem-se como novos e desconhecidos. ${ }^{8}$ Desse modo, revelam sua verdadeira essência. De Chirico transporta o mecanismo de isolamento, estranhamento e desvelamento do universo melancólico para o pictórico, estabelecendo o "princípio da revelação na pintura".

Para De Chirico, a "revelação" de uma obra de arte pode ser espontânea ou estimulada. Quando espontânea pertence a uma classe de sensações raras e estranhas. Porém, quando estimulada como, por exemplo, por intermédio de uma disposição de objetos, essa obra estará ligada à circunstância do seu nascimento. ${ }^{9}$ A semelhança existirá, contudo, se dará de modo estranho ou até mesmo metafísico:

\footnotetext{
${ }^{6}$ DE CHIRICO, Giorgio. "Meditações de um Pintor", 1912. In: CHIPP, H.B. Teorias da Arte Moderna ... op. cit., p. 403

${ }^{7}$ Idem.

${ }^{8}$ Idem.

${ }^{9}$ Idem.
} 
Acredito que, de certo ponto de vista, a visão de alguém num sonho é uma prova da realidade metafísica, e assim, do mesmo ponto de vista, a revelação da obra de arte é prova da realidade metafísica de certos acontecimentos ocasionais que por vezes sentimos na forma e maneira pela qual alguma coisa provoca em nós a imagem de uma obra de arte, uma imagem que desperta em nossa alma a surpresa. ${ }^{10}$

De Chirico procura atingir o forte e misterioso sentimento que havia descoberto em Nietzsche. Para o artista, Schopenhauer e Nietzsche são os primeiros filósofos a ensinar a significação profunda do stimmung da vida, enfatizando que esse "sentimento" pode ser convertido em arte, pois designa a integração momentânea e recíproca da alma do sujeito e da atmosfera do mundo ao redor. ${ }^{11}$ Uma visita a Turim, a cidade dos espaços metafísicos, num verão muito quente, impressiona De Chirico definitivamente e inicia uma nova fase. ${ }^{12}$ $\mathrm{O}$ artista afirma que as cidades italianas têm a condição ideal para o stimmung, ou seja, para a atmosfera senso moral - sensação que procura transmitir em suas praças:

Esta sensação extraordinária pode ser provada (mas é necessário, naturalmente, ter tido a sorte de possuir faculdades como as que possuem) digo, nas cidades italianas e em qualquer cidade mediterrânea, como Gênova e Nice, mas a cidade italiana por excelência para observar este fenômeno extraordinário é Turim. ${ }^{13}$

A arquitetura e a atmosfera da cidade deserta e desconectada da realidade são as principais influências para a produção em Paris. $\mathrm{O}$ artista chega à cidade na noite de 14 de julho de 1910. De Chirico está novamente sofrendo de melancolia. O trauma de mais uma mudança reafirma um de seus mitos de infância: a instabilidade de cidades e lares. Em sua iconografia registram-se temas de partidas e chegadas: o filho pródigo, Heitor e Andrômaca, os

\footnotetext{
${ }^{10}$ DE CHIRICO, Giorgio. Memorie della mia vitta ... op. cit.

${ }^{11}$ HOLZHEY, M. De Chirico (1888-1978): Le Mythe Moderne...op. cit., p. 6 e seguintes

12 Magdalena Holzhey afirma que De Chirico passa uma temporada em Turim por ser condenado à prisão por desertar. De Chirico reconhece que Turim o inspira na série de obras produzida durante 1912 e 1915. Essa produção deve-se muito a Nietzsche com sua maneira de escrever rica em metáforas misteriosas que nutre estética e iconograficamente De Chirico. Idem.

${ }^{13}$ DE CHIRICO, Giorgio. Memorie della mia vitta ... op. cit.
} 
Argonautas, cavaleiros errantes, partida do poeta, entre outros. ${ }^{14} \mathrm{O}$ "nomadismo" da família De Chirico espelha-se em sua produção artística - nesse aspecto, devese lembrar da inclinação dos melancólicos para longas viagens. O mito dos Argonautas torna-se especial: a aventura de Jasão e os Argonautas na cidade de Volos em busca do velocino de ouro (remete ao próprio nascimento do artista ocorrido naquela região). ${ }^{15}$ Em sua autobiografia, o artista narra suas memórias em terceira pessoa e se personifica como um argonauta. Fornece à sua própria vida uma dimensão mítica. Mais tarde, o mito dos argonautas será recorrente em seus trabalhos. ${ }^{16}$

No mesmo período, De Chirico toma conhecimento do Salão de Outono, dos pintores revolucionários, de Picasso, do Cubismo, das Escolas Modernas. Incentivado por Calcovoressi, um crítico musical amigo de Andrea, inscreve-se no salão. Apresenta os trabalhos produzidos em Florença: Enigma de Uma Tarde de Outono (1909), Enigma do Oráculo (1909) e o Autorretrato (1911) com dedicatória nietzschiana. $\mathrm{O}$ fato de ter sido selecionado e a repercussão favorável da mostra estimulam De Chirico a continuar sua produção artística.

\footnotetext{
${ }^{14}$ BARBOSA, Paulo Roberto Amaral. Giorgio De Chirico no Acervo MAC USP ...op. cit., p. 50 e seguintes.

${ }^{15}$ Jasão é um príncipe grego cujo trono é usurpado por Pélias que, para afastar o jovem da Tessália, o incumbe de procurar o "Velocino de Ouro" (Tosão do carneiro que Hermes presenteia a Néfele, que além de ser de ouro, tinha a faculdade de falar e voar pelo espaço), que pertence à família e que está no reino da Cólquida. Numa missão considerada impossível, Jasão aceita a incumbência e manda que os arautos convoquem guerreiros, jovens gregos amantes de aventuras, muitos dos quais se tornam depois conhecidos entre heróis e semideuses. Entre eles: Hércules, Teseu, Orfeu e Nestor. Naquele tempo, a única navegação conhecida pelos gregos é realizada em pequenos botes ou canoas, feitos de tronco de árvores, de modo que, quando Jasão solicita a Argos a construção de uma embarcação capaz de transportar cinquenta homens, o empreendimento é considerado gigantesco. A embarcação é chamada de "Argo", em homenagem ao seu construtor. A "Argo", com sua tripulação de heróis deixa a costa da Tessália, faz a travessia para Mísia e dali passa a Trácia, onde os argonautas encontram o sábio Frineu e dele recebem instruções sobre o curso, e desembarcam em segurança no reino de Cólquida. Etes, o rei admite entregar o Velocino se Jasão cumprisse a tarefa de arar a terra com dois touros de patas de bronze que soltam fogo pela boca e pelas narinas, e semeasse os dentes do dragão que Cadmo mata e dos quais sai, uma safra de guerreiros, que voltam suas armas contra o semeador. Jasão aceita as condições, uma vez que já consegue pleitear sua causa junto a Medeia, filha do rei, uma poderosa feiticeira e que se apaixona perdidamente por ele. E Jasão oferece-lhe em troca, casamento. Cumprida a tarefa com sucesso, resta ainda adormecer o dragão que guarda o velocino. Com a ajuda de um encantamento de Medeia, o dragão que nunca dorme, fecha os olhos e Jasão pode matá-lo e apoderar-se do velocino. Acompanhado dos argonautas e de Medeia, Jasão retorna a Tessália e consagra "Argo" a Netuno. www.paideiaonline.org/. Acesso em 23 de dezembro de 2010.

${ }^{16}$ HOLZHEY, M. De Chirico (1888-1978): Le mythe moderne...op. cit.
} 
O encontro com Guillaume Apollinaire torna-se o estímulo para a participação do artista no ano seguinte, no Salão dos Independentes. Desta vez, apresenta as telas: A Melancolia da Partida (1912), O Enigma da Hora (1910/1911) e O Enigma da Chegada depois do Meio-Dia (1911/1912). À época, Guillaume Apollinaire acompanha a carreira de De Chirico, apresentando-o ao ambiente cultural de Paris, a Picasso, Braque, Mancusi, Derain e Max Jacob. Em novembro de 1913, apresenta no Salão de Outono, Retrato de Madame L Gartzen (1912), A Melancolia de uma Bela Tarde (1912), A Torre Vermelha (1912) e Etude (1912). A Torre Vermelha é o seu primeiro trabalho vendido. Já A Melancolia da Partida e A Melancolia de uma Bela Tarde demonstram explicitamente as primeiras preocupações do pintor com o repertório que envolve o mal-estar humano. De Chirico reflete sob suas condições físicas, morais e psicológicas e retrata a junção dos melancólicos (corpo e alma).

No mesmo período, Andrea De Chirico adota o nome de Alberto Savinio, para diferenciar-se de De Chirico e homenageia Guillaume Apollinaire, pois a personagem Albert Savine aparece na sua crônica literária. Os irmãos frequentam os ambientes artísticos e literários de Paris, que reconhecem, rapidamente, a absoluta originalidade de seus trabalhos. Os artistas compartilham das mesmas experiências estéticas posto que a pesquisa de Savinio na música em muito se assemelha a de Chirico na pintura: uma reordenação da memória, da melancolia e dos sonhos. ${ }^{17}$

Paul Guillaume adquire alguns trabalhos de De Chirico e manifesta seu interesse em ser seu marchand. A produção de De Chirico é abundante. O artista inventa e elabora com extraordinária fantasia temas de misteriosa magia poética e melancólica: visões arquitetônicas, praças da Itália, estátuas solitárias, objetos próximos a manequins inquietadores e suas primeiras naturezas-mortas. De Chirico tem consciência da evolução de sua obra e, principalmente, da realidade que o cerca:

\footnotetext{
${ }^{17}$ BARBOSA, Paulo Roberto Amaral. Giorgio De Chirico no Acervo MAC USP ... op. cit., p. 15 e seguintes.
} 
Via que o interesse pela minha pintura aumentava, via as revistas e jornais publicarem minha obra, ganhava um pouco de dinheiro e reconhecimento; era feliz. Mas chega o fatal 1914; era verão e fazia um calor abafado. Um belo dia tudo começou a ficar confuso e cambaleante; as pessoas se reuniam nas ruas; os jornais saqueados; o crime de Sarajevo: a guerra ${ }^{18}$.

No ano de 1914, em Paris, trabalha-se pouco. Amigos e conhecidos desaparecem atendendo à convocação militar. Muitos voltam aos seus países, imaginando que cumprem um dever. No círculo de convivência de De Chirico, muitos provam uma espécie de vergonha de nascer em certo país, e ter nacionalidade e pais de outro, por exemplo, ser italiano, filho de pais italianos e não ter nascido na Itália, pai francês, filho de franceses, mas nascido fora da França. $^{19}$

Muitos tinham este tipo de pudor, inclusive eu e meu irmão, e ingenuamente acreditamos que apresentando-nos ao alistamento militar haveríamos de cumprir nosso dever e de alguma forma mudaríamos algo. ${ }^{20}$

A atmosfera é muito tensa no ambiente francês, os pintores recolhem-se em suas poéticas. De Chirico vive uma experiência constrangedora e profética: retrata Guillaume Apollinaire como "homem-alvo". Pouco tempo depois, no front, o poeta será ferido justamente onde De Chirico, na sua pintura, marca uma circunferência, como um alvo, em sua cabeça.

No verão de 1914, De Chirico regressa à Itália, passando em revista em Florença, onde é destinado ao $27^{\circ}$ regimento de infantaria de Ferrara. Seu frágil estado de saúde o conduz ao serviço como auxiliar, permitindo a continuidade do exercício da pintura. Nessa ocasião, conhece Philippo de Pisis, Carlo Carrá e junto com Alberto Savinio, que também presta serviço em Ferrara, inauguram a Pintura Metafísica.

\footnotetext{
${ }^{18}$ DE CHIRICO, Giorgio. Memorie della mia vitta ...op.cit.

${ }^{19}$ Idem.

${ }^{20}$ Idem.
} 

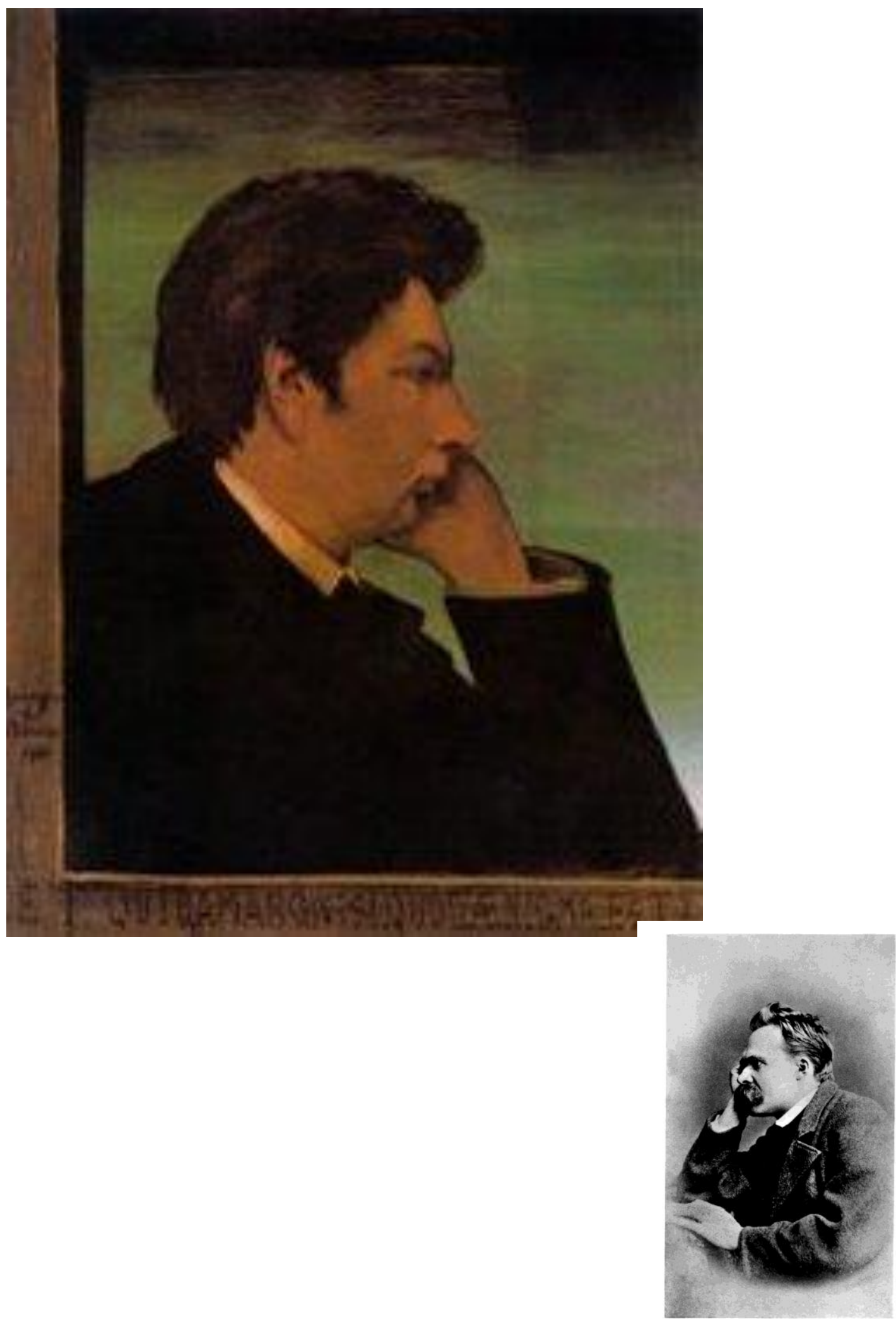

Giorgio De Chirico.

Autorretrato, óleo sobre tela (72,5 x $55 \mathrm{~cm}), 1911$.

Dedicatória Friedrich Nietzsche.

Coleção Particular, Lugano. Itália 


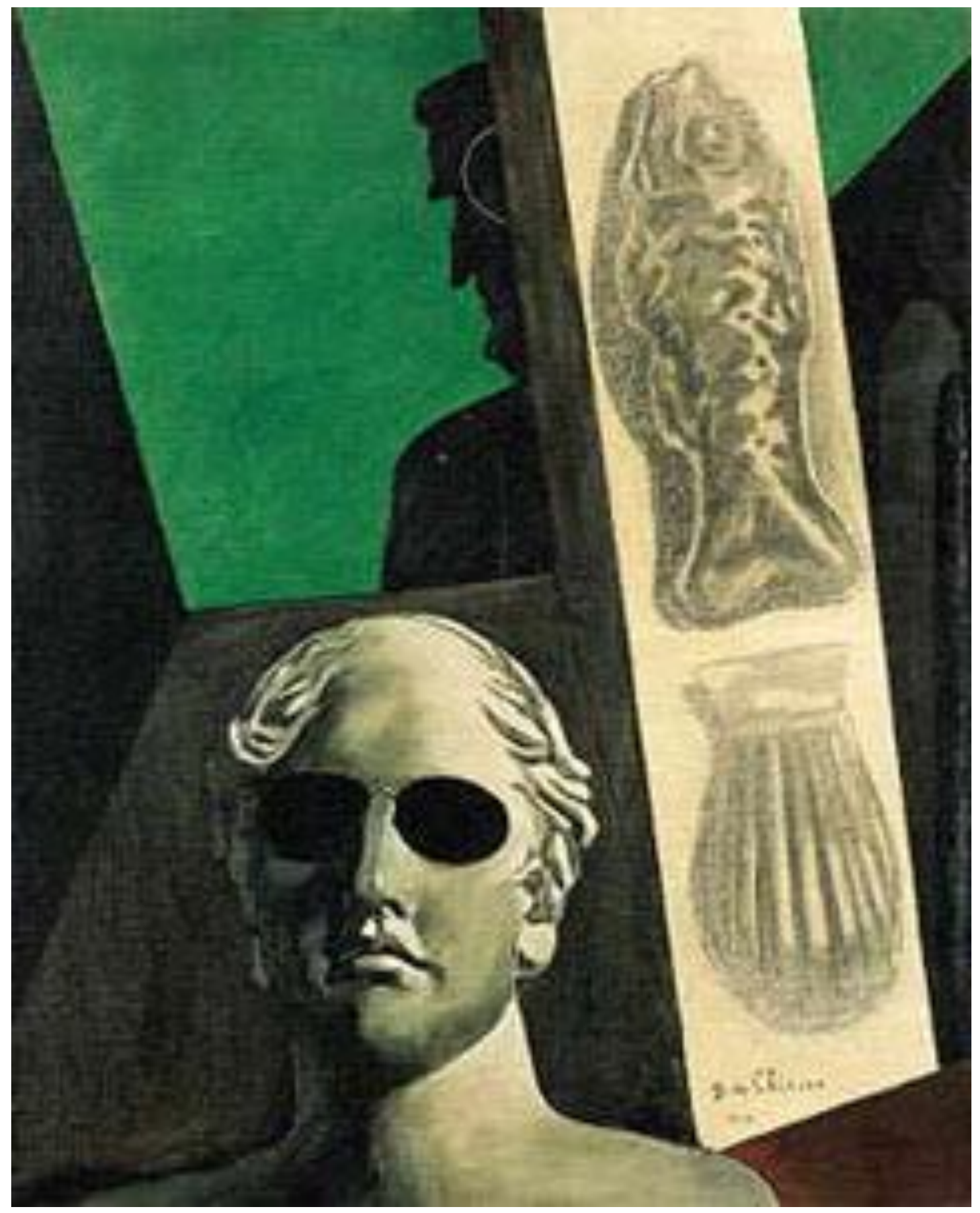

Giorgio De Chirico. Retrato de Guillaume Apollinaire, óleo sobre tela, (81,5 x 65 cm), 1914. Musée d’Art Modern, Centre Georges Pompidou, Paris. França. 


\section{A "Revelação" e a Guerra}

A I Guerra Mundial, apresentada pela propaganda como "última das guerras", como a solução radical para os conflitos, os desequilíbrios e o mal-estar prevalecentes da política imperialista que rege a economia europeia, em seu primeiro momento, conta com a adesão de diversos intelectuais e artistas somados a milhares e milhares de pessoas anônimas que se alistam voluntariamente para participar do momento redentor que levaria à construção de um novo mundo. ${ }^{21}$ Os sentimentos de euforia e esperança alimentam os esforços de guerra - do conflito que chamado de "guerra total" por mobilizar a grande indústria, a rede de comunicações de massa (cinema, rádio, fotografias e cartazes), envolve o cotidiano das populações e o front. Porém, a euforia inicial dissipa-se, inversamente, ao aumento da carnificina, transformando-se em desespero, horror e ódio. ${ }^{22}$ As expectativas frustradas de, através da Guerra, criar-se um mundo perfeito e as cumplicidades que são angariadas nos instantes iniciais do conflito deixam um lastro de ressentimento e melancolia.

O historiador Nicolau Sevcenko cita que cerca de 25 milhões pessoas morrem entre os anos de 1914 e 1923 devido a Guerra e a acontecimentos interrelacionados. A mudança de escala das mortes em conflitos torna-se traumática, basta comparar aos 174 mil mortos na última guerra de grandes proporções, a Franco-Prussiana, e "ninguém, nem mesmo os oficiais familiarizados com os modernos equipamentos bélicos, estava preparado para essa magnitude de perdas humanas". ${ }^{23}$ A presença da tecnologia, personificada pelas máquinas (metralhadoras, automóveis, aviões, fotografias aéreas e tanques) altera as

\footnotetext{
${ }^{21}$ SEVCENKO, Nicolau. Orfeu Extático na Metrópole. São Paulo, sociedade e cultura nos frementes anos 20. São Paulo: Companhia das Letras, 1992, p. 164.

${ }^{22}$ Idem.

${ }^{23}$ Idem, p. 165.
} 
tradições nas batalhas (a associação entre aristocracia, cavalaria e infantaria torna-se prática suicida) e como resultado gera um saldo de mortos assustador. ${ }^{24}$

Na Itália, a busca pela "transformação do mundo", por intermédio da Guerra, está convertida no empenho dos intelectuais destinados a construir a “nova ordem”. As condições históricas da Itália - recentemente unificada (1870) e liberta do domínio estrangeiro; fortemente dividida econômica, política e regionalmente; com uma nova elite despreparada e desligada dos meios intelectuais - são elementos para a construção de uma nova identidade nacional, vinculada a um projeto político integrador. Por essa razão, "a guerra total" significa a construção de "uma nova ordem" concebida através de sua intelectualidade: "a Itália já tendo sido criada, o problema agora é criar os italianos". ${ }^{25}$ Giorgio De Chirico e seu irmão Alberto estão entre os "italianos" que necessitam confirmar sua identidade - nascidos na Grécia, mas filhos de pais italianos sentem as contingências e o sentimento dos nacionalismos exacerbados.

No $27^{\circ}$ Regimento de Infantaria Caserma Pollastrini, em Ferrara, de início os irmãos sofrem com o isolamento e buscam conservar os laços com os amigos que ficam em Paris. De Chirico mantém seus contatos com o seu marchand, Paul Guillaume, com quem renova o seu contrato. Porém, com o decorrer do tempo, os irmãos se abrem para a beleza estranha e para a atmosfera fechada da pequena cidade. O lugar se torna uma fonte de inspiração: as pequenas vitrines dos ateliês, as padarias, as butiques, entre outros espaços arquitetônicos despertam novos temas e motivos. É perceptível uma transformação na poética de De Chirico: os grandes espaços vazios, com sombras longas, povoados por estátuas solitárias ou por manequins, dão lugar aos interiores onde se amontoam objetos singulares, esquadros, mapas geográficos, bolos e outras massas - De Chirico agora penetra nos quartos dissimulados atrás das arcadas obscuras e das portas e janelas fechadas, e lá descobre as coisas que cercam os habitantes daquela cidade. $\mathrm{O}$ mundo dos objetos, semelhantes à

\footnotetext{
${ }^{24}$ Idem.

${ }^{25}$ Frase do primeiro-ministro piemontês Massimo d’Azeglio. APUD. SEVCENKO, Nicolau. Orfeu Extático na Metrópole. São Paulo, sociedade e cultura nos frementes anos 20...op. cit., p. 206.
} 
gravura de Dürer, adentra no repertório compositivo de Giorgio De Chirico - eles auxiliam na construção da atmosfera estranha de suas telas, pois são destituídos de suas funções habituais.

Em 1916, De Chirico faz novas amizades na Itália. Os irmãos gostariam de se fazer reconhecidos como italianos e se esforçam para propagar a arte metafísica no país. De Chirico firma uma forte amizade com o pintor Carlo Carrà. Depois de uma crise de melancolia profunda, Giorgio e Carrà são declarados inválidos para ações militares e tornam-se secretários no caixa do escritório do Hospital Militar Villa Del Seminário. As pinturas de Carrà, durante sua estadia na Villa Del Seminário, são bastante diferentes das futuristas produzidas anteriormente. O pintor está completamente influenciado pelo repertório poético De Chirico, chegando a imitar quase que literalmente seus elementos característicos. Para De Chirico os dois pintores deveriam organizar uma exposição importante em Milão e em outras cidades italianas para divulgar a Pintura Metafísica. Carrà, no entanto, faz grande exposição pessoal em Milão sem dizer nada ao amigo. A partir desse episódio, o debate sobre a Pintura Metafísica altera a relação entre os dois pintores. Esta é a primeira de numerosas decepções que De Chirico conhece em terras italianas.

Contudo, a Pintura Metafísica é anterior ao convívio de De Chirico e Carrá. Seus indícios residem no episódio da Piazza Santa Croce, em Florença, em 1910, já mencionado anteriormente. A "revelação" é uma descrição do que Jean Clair chama de "síndrome da melancolia". ${ }^{26}$ As circunstâncias geográficas e as localizações temporais, a descrição de uma desordem psicológica, tudo está conforme o simbolismo tradicional do complexo melancólico. ${ }^{27}$ A estação do ano é o outono; as características físicas do tempo são o frio e o seco; a hora do dia é o crepúsculo, com suas sombras claras e alongadas. ${ }^{28} \mathrm{O}$ cenário da arquitetura clássica propõe os diferentes emblemas da escultura e da arquitetura, a simbologia de números e das medidas. Exceto a estátua, a praça é solitária e

\footnotetext{
${ }^{26}$ CLAIR, Jean. "Maquinismo e Melancolia". In: GALERIES NATIONALES DU GRAND PALAIS, Mélancolie: Genie et Folie en Occident...op.cit., p. 440 e seguintes.

${ }^{27}$ Idem.

${ }^{28}$ Idem.
} 
melancólica - todos esses traços estão de acordo com a iconografia tradicional. ${ }^{29}$ Enfim, De Chirico está convalescente dos problemas ocasionados pela atrabilis em suas Memórias, o pintor registra suas desordens intestinais em diversos momentos de sua vida.

Nesse ponto, chama-se a atenção para o fato de que, estudioso das letras gregas, De Chirico, sem dúvida, não ignora a passagem de Problema $X X X$ de Aristóteles que trata dos quatro temperamentos: a melancolia, como humor e como temperamento provoca o ar; por isso os médicos dizem que a flatulência e as desordens abdominais devem-se à ação da bílis negra. ${ }^{30}$ A longa tradição médico-filosófica, tratada anteriormente, na primeira parte desse estudo, eclode na "revelação" da Piazza Santa Croce e nos conhecimentos adquiridos pelo artista que concebe "os homens excepcionais" como dotados de natureza melancólica. Nesse sentido, a "revelação" pode ter atribuído a Giorgio De Chirico a concepção de sua natureza dual (melancólica/excepcional). Mas, em De Chirico, o surto melancólico caracteriza-se por um estado de estupor no qual a realidade parece, de repente, estranha aquele que a contempla, o pensamento não tem mais poder sobre os objetos, o mundo visível perde o seu sentido ou, mais exatamente, o mundo físico, o mundo dos fenômenos encobre um sentido indecifrável, um sentido propriamente metafísico, cuja inacessibilidade dá o sentimento inconsolável.

No registro de uma melancolia, própria do início do século XX, a obra de Giorgio De Chirico apresenta paralelos com a de Dürer que, como visto anteriormente, dá à melancolia dos antigos um sentido novo. No início da Renascença, o sentimento da melancolia que exprime a gravura Melancolia I, nasce do divórcio entre a possibilidade oferecida ao espírito humano de pensar o mundo como uma totalidade inteligível - neste breve e singular momento em que o artista, "homem-artesão", torna-se o "politécnico" (o matemático, o engenheiro, o geômetra e o artista) - e, entretanto, condenado, atormentado pelo

\footnotetext{
${ }^{29}$ Idem.

${ }^{30}$ Idem.
} 
humor negro, não mais compreende a dimensão metafísica. ${ }^{31}$ A conquista do objeto pelo melancólico se dá por meio da meditação morosa. O olhar para dentro de si por intermédio dos objetos é defrontar-se com dúvidas e desesperos. O resultado é sempre a insatisfação, pois não existe nenhuma certeza consoladora na esfera da indistinção do sujeito e do objeto.

Em De Chirico, o homem moderno - impactado pelos fatos que levam à Guerra - se vê divorciado definitivamente do material e do espiritual. A morte, assim como no período da peste, está bem próxima do mundo em conflito. Durante os acontecimentos da I Guerra Mundial, ao contrário do apelo renascentista, a racionalidade não pode mais identificar-se com a realidade. Os avanços tecnológicos, os conflitos sangrentos e os ódios políticos remetem à dimensão emocional, às correntes irracionais e, sobretudo, à renovação instintual. Diante desse quadro e, consequentemente, frente a um saber fragmentado, o espírito só poderia assumir a esfera metafísica das aparências, impotente, em contrapartida, a apreender o fundamento racional. ${ }^{32}$

Ao longo de 1914, um ano fecundo para De Chirico, a atmosfera cercada pela Guerra deixa sua marca na obra do pintor. Em $O$ Enigma da Fatalidade (1914), o artista é estimulado pelos textos filosóficos de Otto Weininger que refletem sobre o efeito inquietante do triângulo - do ângulo agudo; da forma plástica que pontua algo. A luva remete ao repertório de Max Klinger que faz uso desta imagem para representar o pintor-narrador, na gravura Paráfrase sobre a descoberta de uma luva (1881), que nas cenas estranhas, frequentemente irreais, descrevem os desejos, os sonhos de um homem que vive uma paixão infeliz. Nessa gravura, os objetos, especialmente as peças do vestuário, contam uma cena nonsense do século XIX. Já na obra de De Chirico, o recorte da cena remete aos espaços arquiteturais cercados pelo triângulo, a luva direciona ao conceito da manipulação do ambiente.

A profusão de objetos presentes em muitas das composições de Giorgio De Chirico reafirma-se à semelhança da tradição perpetuada por Dürer - estes

\footnotetext{
${ }^{31}$ Idem.

${ }^{32}$ Idem.
} 
são carregados de sentidos que mostram a impotência da natureza humana frente às possibilidades propiciadas pelas coisas. Contudo, somente os objetos narram o enredo da tela. Diante do sujeito clássico em escombros, De Chirico narra, principalmente, a metamorfose da subjetividade, ativada pelo recesso da experiência e pela sabedoria esvaziada. Em suas obras, De Chirico faz uma justaposição de tempos diferentes, melhor dizendo inconciliáveis - a era antiga e a era moderna, lembranças e tempo presente, mito e realidade.

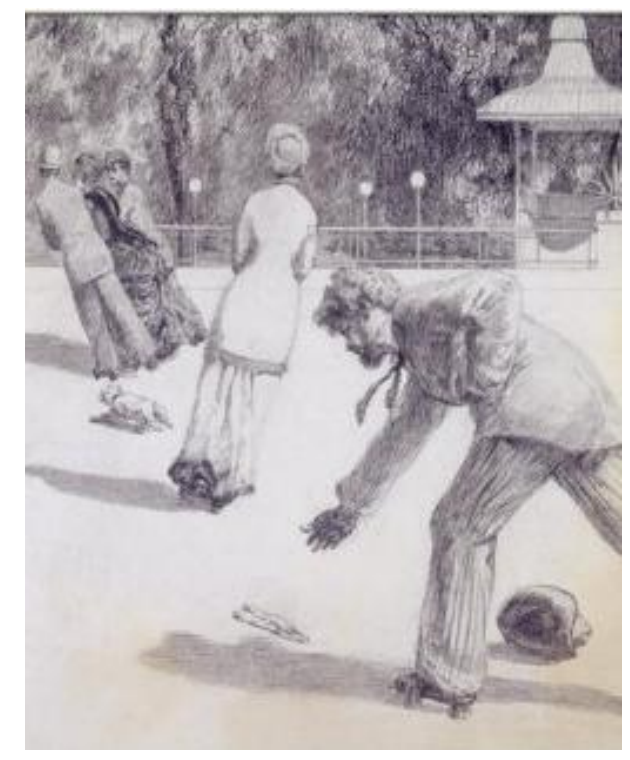

Max Klinger, Paráfrase sobre a descoberta de uma luva, 1881 , nanquim lavado e caneta, $(62 \times 70 \mathrm{~cm})$.

Coleção Particular

Giorgio De Chirico. O Enigma da Fatalidade, óleo sobre tela (138 x 95,5 cm), 1914.

Kunstmuseum, Basileia. Suíça.

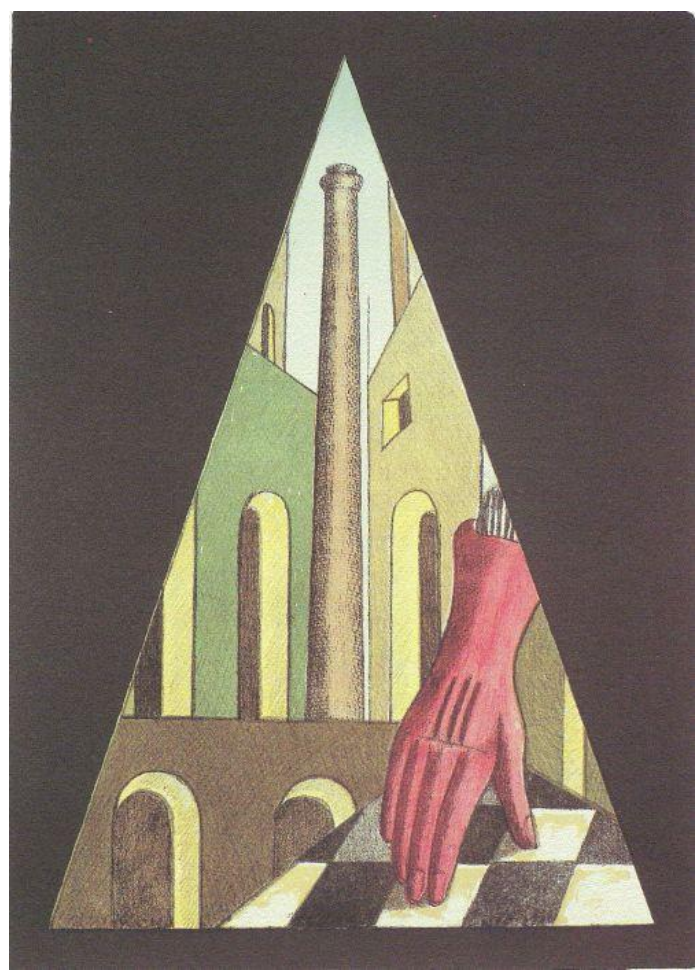




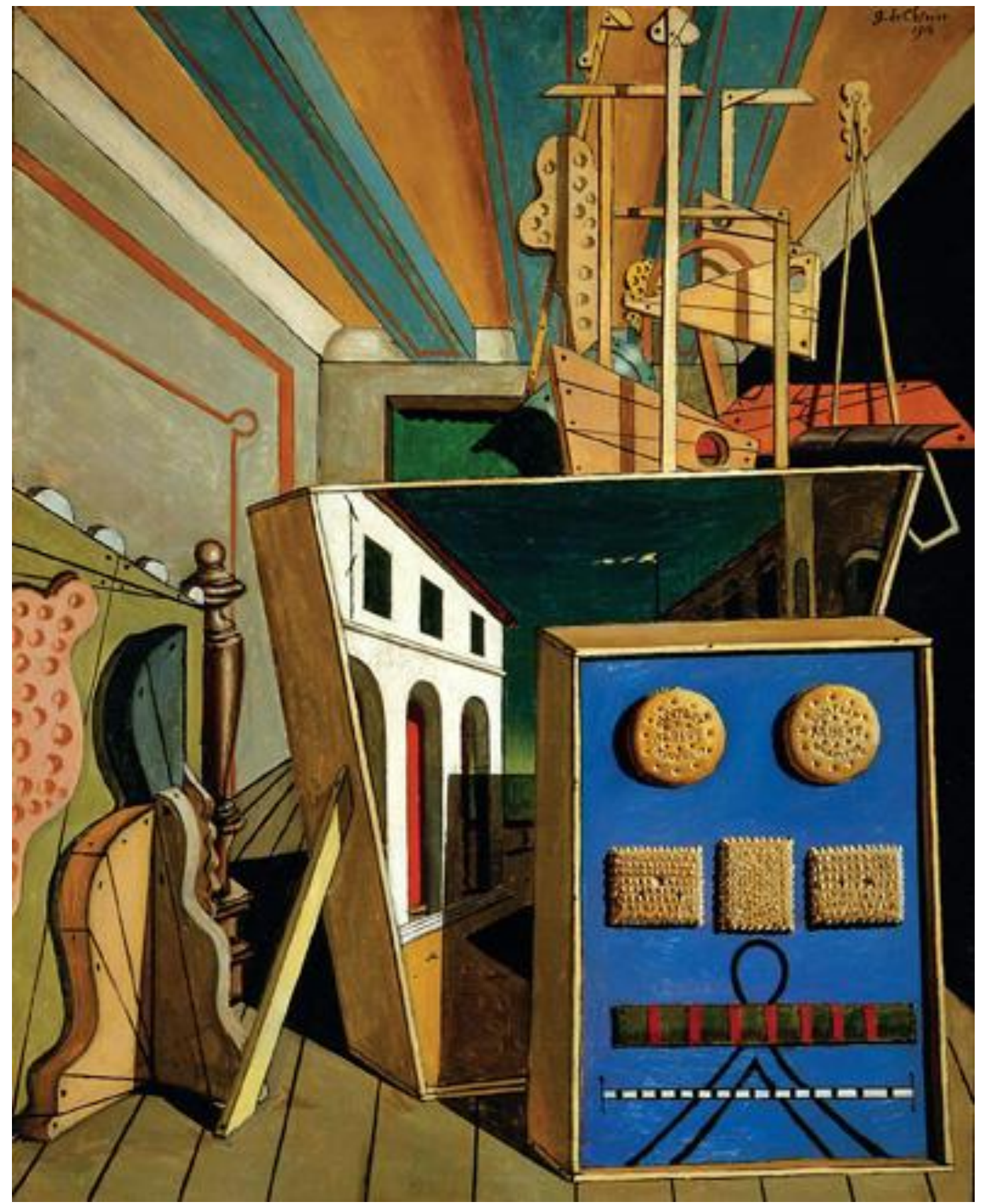

Giorgio De Chirico, Interior Meta físico com biscoito, óleo sobre tela, 1918. 
Até o verão de 1918 são produzidas muitas telas que, posteriormente, denominar-se-ão ferrarenses: manequins, interiores metafísicos, praças italianas. No outono desse ano, De Chirico e a mãe moram em um hotel. Alberto Savinio se junta a eles vindo da Macedônia.

\begin{abstract}
Uma tarde, quando pintava um quadro de interior metafísico (...) escutei um barulho vindo da rua, um barulho insólito como de multidão agitada, e repentinamente meu irmão entra gritando no quarto que a guerra tinha acabado, a Alemanha tinha pedido armistício. $^{33}$
\end{abstract}

No mundo pós-1918, dilacerado por conflitos, convulsões revolucionárias e contra-revolucionárias, a velha ordem entra em colapso e a "era da violência" está oficialmente inaugurada. Nesse contexto, surge uma reorientação simbólica, ocasionada pela disjunção entre a base religiosa e a irrupção de novas tecnologias, assentadas sobre a aceleração, fragmentação e concentração isoladora das grandes cidades. ${ }^{34}$ A atitude mais típica do pós-guerra sugere o abandono da permissividade cultural, do ceticismo e do racionalismo e, ao mesmo tempo, motiva o retorno militante aos mitos, aos instintos e às crenças. Depois da Guerra, a "estética da tabula rasa e da terra arrasada parecia soar como o próprio clarim anunciador de um novo tempo". 35 As vanguardas artísticas, surgidas antes do período bélico, que possuem a esperança da redenção pela "guerra total", estão abaladas, particularmente o Futurismo de Marinetti que, antes do conflito armado, se organiza a partir de uma estrutura militar e patriótica, encontrando traços de identidade com o fascismo anos mais tarde. ${ }^{36}$

\footnotetext{
${ }^{33}$ DE CHIRICO, Giorgio. Memorie della mia vitta..., op. cit.

${ }^{34}$ SEVCENKO, Nicolau. Orfeu Extático na Metrópole. São Paulo, sociedade e cultura nos frementes anos 20... op. cit., p. 164.

${ }^{35}$ Idem.

${ }^{36}$ De modo geral, as vanguardas artísticas caracterizam-se por uma sucessão ininterrupta de saltos e mudanças bruscas. A tradição renascentista é rompida uma ou outra vez, tanto em função de cada novo movimento e seus manifestos, quanto pelo surgimento de cada novo artista. PAZ, Octavio. "Picasso: O Corpo a Corpo com a Pintura". Esse texto escrito originalmente para o catálogo da exposição Los Picassos de Picasso, que inaugura em 1982 o Museu Rufino Tamayo (México) e editado no volume Sombras de Obras, que reúne vários ensaios de Octavio Paz.
} 
Em 1919, a ideia da Scuola Metafísica é atingir uma realidade visionária, na qual o pintor trabalha num estado de melancolia e devaneio. A Scuola Metafísica possui como princípio básico: provocar os inquietantes estados de espírito que levam a duvidar da existência desligada e impessoal do mundo empírico, visualizando cada objeto somente como a parte exterior de uma experiência imaginativa e enigmática em seu significado. Esse estado da arte seria possível através de construções sólidas, claramente definidas e que, paradoxalmente, parecem dotadas de total objetividade. Os adeptos da Pintura Metafísica abordam, com frequiência, as composições "clássicas” e evitam a autoexpressão espontânea. ${ }^{37}$

Na perspectiva da Pintura Metafísica, Carrà e De Chirico não estão interessados em sonhos, mas no fenômeno mais intrigante das associações que nascem das observações cotidianas, obtidas a partir do estado melancólico:

É necessário um controle constante de nossos pensamentos e de todas as imagens que nos vêm à mente, mesmo quando acordados, e que têm, mesmo assim, uma íntima relação com as imagens que encontramos nos sonhos. É curioso que nenhuma imagem onírica, por mais estanha que pareça, nos atinge como força metafísica. ${ }^{38}$

Como já se adiantou no presente estudo, a concordância entre Carrà e De Chirico não dura muito tempo. De Chirico sustenta que Carrà teria assumido toda a autoria da Pintura Metafísica, ignorando que seus trabalhos, elaborados antes da Guerra, já haviam sido consagrados metafísicos. Não é essa a única polêmica em torno da Pintura Metafísica. Muitas outras surgem. A mais notória é a negação de laços existente entre o fazer artístico metafísico e o surrealista.

Nos anos entreguerras, portanto, a mensagem das "ditas vanguardas" muda de sentido. Todo um mundo, novamente, está ao ponto de desaparecer e, o “chamado à ordem" nas artes, talvez tenha sido apenas uma breve ilusão de

\footnotetext{
${ }^{37}$ Idem.

${ }^{38}$ De Chirico, Giorgio. "Sull'arte metafísica", Valori Plastici (Roma), 1, 4-5 (abr/maio de 1909), p. $15-18$
} 
renovação da arte italiana. ${ }^{29}$ Sob esse ponto de vista, a poética de De Chirico situa-se na fronteira entre o "retorno ao passado" e/ou "rumo ao futuro". A Pintura Metafísica é sua alternativa para as indagações feitas por seu tempo: suas imagens fascinam por uma consciência da força ameaçadora e do presságio do desconhecido, tendendo antes para uma melancolia suave (a "doce melancolia" talvez, menos mórbida e mais contemplativa), uma espécie de reflexão inquietante - esses elementos irão inspirar os surrealistas. Sua pintura metafísica gera aquilo que o poeta surrealista André Breton chama de "mito moderno". Para o poeta surrealista, a obra metafísica de De Chirico traduz a melancolia, a perda do sentido e a alienação do homem moderno

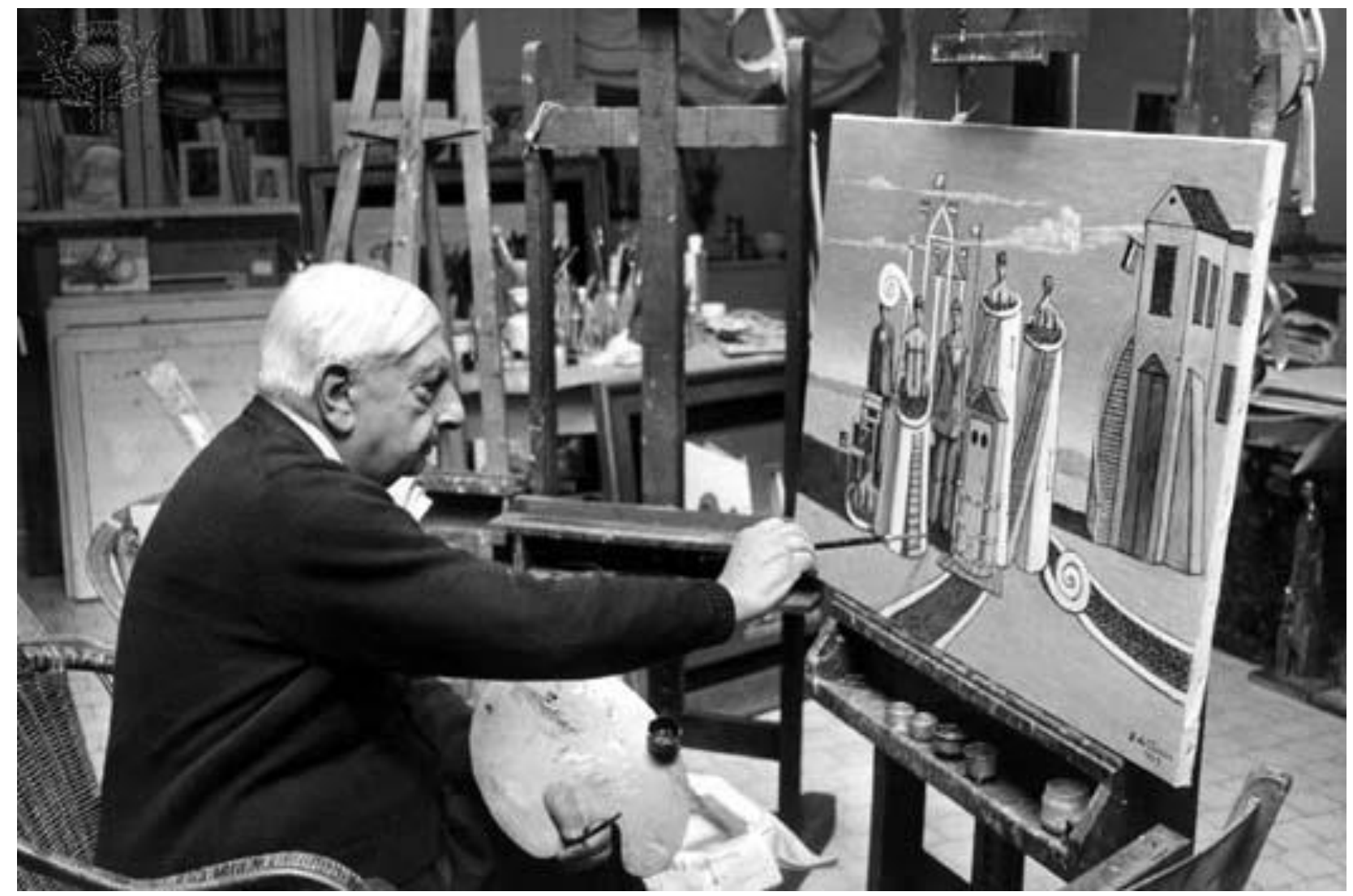

Giorgio De Chirico em seu ateliê, sd. 


\section{O Retorno ao Passado e/ou Rumo ao Futuro}

$\mathrm{O}$ rosto volta-se para o passado. Onde vemos uma cadeia de acontecimentos à nossa frente, ele vê uma única catástrofe, que prossegue amontoando detritos sobre ruínas até chegarem aos seus pés (...) Mas sobre ruínas até chegarem aos seus pés (...). Mas sopra uma tempestade dos lados do Paraíso, batendo em suas asas com tal força que o Anjo não mais pode fechá-las. Essa tempestade o leva irresistivelmente para o futuro, para o qual dá as costas, enquanto o monte de detritos a seus pés chega aos céus. Essa tempestade é o que chamamos de progresso. ${ }^{39}$

Walter Benjamin

A I Guerra Mundial cria, entre a intelectualidade italiana, uma falsa expectativa de acesso à Europa progressista e de retirada do caráter provinciano de sua arte. A estética do Futurismo, deflagrada em 1909, com sua poesiamáquina, de ritmo acelerado para exprimir a força impulsiva do instinto, é um ímpeto renovador já exaurido nesse período. Os fatos da Guerra demonstram que a fé no progresso pode aproximar os homens da morte e da destruição em massa. Desde 1910, De Chirico se opõe às ideias futuristas e valoriza uma arte acima da história - metafísica - de uma tendência classicista absoluta, exterior ao tempo. ${ }^{40} \mathrm{~A}$ posição de De Chirico frente aos princípios futuristas ocorre, principalmente, pelo oferecimento de nova poética distante do alarido das fábricas, dos negócios e das guerras. ${ }^{41}$ Sua arte não pretende manter qualquer relação com o mundo presente, não quer combater por causa alguma, não quer se aliar a qualquer ideologia; manifesta a sensação de morte de um mundo que até aquele momento é considerado demasiado vivo. ${ }^{42}$

\footnotetext{
${ }^{39}$ BENJAMIN, Walter. One-way street and other writings. Londres, 1979, p. 84-85.

${ }^{40}$ ARGAN, Giulio Carlo. Arte Moderna. São Paulo: Companhia das Letras, 1992, p. 372.

${ }^{41}$ Idem.

${ }^{42}$ Idem.
} 
Segundo Giulio Carlo Argan, entre os anos de 1916 e 1920, a obra de De Chirico constitui o verdadeiro fato novo na arte europeia - mas não é algo revolucionário, antes, decididamente, é anti-revolucionário, contradizendo firmemente as "vanguardas". 43 A visão das vanguardas multiplica os elementos plásticos e os sinais que o mundo moderno dispersa sob a forma de contradições do cotidiano - a opulência tecnológica, a guerra e as subversões visuais desveladas pelas novas dimensões do real (particularmente, o cinema e a fotografia) desembocam em um projeto de superação e totalização. ${ }^{44}$ Nesse momento, a voz de De Chirico levanta-se contra o discurso das "ditas vanguardas", desconfiando do seu fôlego, porque para ele a força geradora de crítica ao sistema não está na disposição de uma leitura, mas na sua constante interpretação. Nesse sentido, a perda de fôlego das vanguardas se refere tanto ao esgotamento político-cultural de suas premissas, quanto pela plena absorção do público de seu apelo formal no que diz respeito à inovação. ${ }^{45}$

As vanguardas elegem os sinais das contradições do sistema e ironizamno diante de seus próprios signos. De alguma forma, anteveem o predomínio da linguagem e dos objetos inerentes ao mundo. Se as vanguardas são consideradas depositárias de linguagens experimentais, isto ocorre porque as pensam como um salto rumo ao novo - "o salto do tigre". ${ }^{46}$ De Chirico percebe que o novo só se dá no "tempo imediato", perdendo sua força no tempo posterior, e constrói sua obra em oposição ao tempo valorizado pelas vanguardas. Por essa razão, o artista atribui a si mesmo o papel de guardião dos mitos e tradições em plena modernidade. $\mathrm{O}$ resgate do passado manteria sua obra como atual em todos os tempos.

Nas citações de Walter Benjamin e nas de De Chirico observa-se que a questão das imagens do mundo urbano é significativa para se entender as implicações históricas da nova condição pós-guerra. Os impactos ocasionados

\footnotetext{
${ }^{43}$ Idem.

${ }^{44}$ Idem.

${ }^{45}$ Idem.

${ }^{46}$ LOWY, Michael. Walter Benjamin: Aviso de Incêndio - Uma Leitura das Teses "Sobre o Conceito de História". São Paulo: Boitempo, 2005, p. 119 e seguintes.
} 
pelo processo de urbanização da vida causam: questionamentos nas modalidades da consciência reflexiva (a arte, a ciência e a política) e indagam a própria possibilidade de inquirir o real e discernir a sua estabilidade. Do ponto de vista humano, atravessar quarteirões e ruas tomadas inteiramente pelo horizonte estanque dos prédios significa perder em superfície espacial, ou em consciência espacial, a relação entre o mundo e a vida. ${ }^{47}$ Por essa ótica, aspectos extremamente importantes para a definição do ser de uma determinada época podem ser fracionados a partir de imagens mentais. Na poética de Giorgio De Chirico, esse mundo entre o urbano, o moderno e o clássico adquire uma luminosidade que invade os cenários e objetos, desafiando qualquer verdade existencial dessa cidade - tornando-a irreal.

As telas de Giorgio De Chirico exigem o desvelar do mundo como campo de referências tanto conceitual quanto perceptivamente dado. São decifráveis, exigem da sociedade uma ação comunicativa, uma leitura. Não há elemento do real que não seja solicitado a entrar na roda viva das alegorias modernas e desafiá-las. Em suas narrativas idiossincráticas, perscrutam os símbolos das mitologias que se erguem no tempo histórico. A estas mitologias não é dado o exercício da totalidade, elas, pelo contrário, procuram disseminar territórios em que se podem flagrar reflexos do ser. A relação com o mundo é mediatizada, não somente pelo mito, pelo divino ou pelo Estado, mas pela linguagem. É dela que advém o caráter profano, materialista e antropológico da atitude moderna em relação à arte.

Em De Chirico, a iniciação contemplativa se dá em uma experiência única, em um ato singular que caracteriza a passagem ao domínio de um determinado mistério. Ora, não há mistérios na "sociedade do espetáculo". Ou há? No repertório metafórico de Giorgio De Chirico, a passagem pelo mistério não se dá num ato ritual singular, mas em série e continuadamente. Os repetidos choques a que o sujeito se vê exposto no mundo moderno não permitem que os

\footnotetext{
${ }^{47}$ Idem.
} 
mitos, aquela interpretação mais ingênua, primitiva e imediata do mundo constituída de sua época, encontrem um nível de apaziguamento.

Para o “pictor optimus”, na negação do presente há a máxima "apenas na história da arte pode existir arte". ${ }^{48}$ A roda da história volta a girar, mas em sentido contrário: o processo involutivo. Com esse pensamento, o movimento dos Valores Plásticos (1920), motivado pela ideias de De Chirico, tenta uma operação ambígua: reconduzir a linguagem moderna àquela que afirma ser a raiz histórica originária de toda a arte europeia, a verdadeira tradição italiana - um “apelo de volta à ordem" ou a antivanguarda. ${ }^{49} \mathrm{O}$ "retorno à ordem" que De Chirico reivindica desde 1910 é a vontade de pensar o futuro da pintura como repetição de seu passado. A tentativa de reconstruir a arte de forma definida é contida novamente em um espaço delimitado e organizado de acordo com referências claras e sólidas, a meticulosidade maníaca, enfim, de um ofício que acredita inspirar-se nas técnicas antigas, na importância doentia associada às receitas práticas. ${ }^{50}$

As obras com conteúdo melancólico são retomadas nas correntes figurativas de 1920, na Itália, particularmente nas vinculadas aos Valores Plásticos $^{51}$ e do Novecento que ilustram, com uma espantosa insistência, o tema da melancolia e outros correlatos, tais como, o sonho, a solidão, o desejo ou a espera. Na produção de Felice Casorati, Carlo Carrà e Arturo Martini encontra-se como figura recorrente de suas obras uma mulher solitária, sonhadora ou

\footnotetext{
${ }^{48}$ ARGAN, Giulio Carlo. Arte Moderna ... op. cit., p. 372.

${ }^{49}$ Idem,p. 374.

${ }^{50}$ Idem

${ }^{51}$ Em janeiro de 1919 é publicado o primeiro número de Valores Plásticos, revista dirigida por Mario Broglio, em Roma, dominada pela tendência metafísica. O número duplo (4 e 5) relativo a abril e maio de 1919 guarda a mais completa exposição do ponto de vista da Scuola Metafísica, com artigos de Carrà, Savínio e De Chirico. Nesse número da revista, De Chirico sustenta que a primeira manifestação consciente da grande pintura metafísica somente poderia acontecer na Itália. Segundo o artista: "A virtuosidade e o gosto artístico bem cultivado, misturado com aquela dose de espírito (...) que tempera 99\% dos habitantes de Paris, sufocariam e impediriam o advento de um espírito profético". Valores Plásticos teve 15 números, entre os anos de 1918 e 1921, transformando-se no veículo de comunicação porta-voz da arte italiana na Europa. ARTE. Speciale - II Secolo lungo della pittura italiana. Milano: Editoriale Giorgio Mondadori, agosto de 2004, p. 11-14.
} 
prostrada, mergulhada numa meditação sem fim e talvez sem causa. ${ }^{52}$ As alegorias de Penélope e Ariadne regressam às telas, corporificando a "doce melancolia" dos séculos XVII e XVIII - o amor resignado e a esperança. A construção alegórica resgata a tradição greco-romana presente na "eterna espera" de Penélope e no amor sem correspondência de Ariadne.

O sentido da melancolia em De Chirico, como se percebe, advém do sentimento que apesar das receitas do enigma e das aparências exteriores de uma ordem plástica restaurada em seu antigo esplendor, nenhum conhecimento universal pode unir a diversidade dos saberes locais. ${ }^{53}$ A unidade, a homogeneidade da arte antiga desaparecidas para sempre, são apenas os suportes de seu poder. Em De Chirico, existe a manifestação poética do eterno retorno de Nietzsche pelo qual um instante se veria subtraído das localizações geográficas e temporais do presente para ser vivido eternamente. Na sua poética, surge um puro acesso de melancolia, no qual se espelha o trabalho do luto da lembrança, o que propicia a experiência da perda irremediável de seu objeto, quer se trate do passado histórico da pintura ou da infância singular do pintor. ${ }^{54} \mathrm{O}$ manejo da perspectiva torna-se traição desse jogo espaço-temporal que, sob a aparência de uma ordem restaurada, descreve de fato as etapas de um espoliamento que leva os signos a uma privação - esse ponto será discutido nesse estudo mais adiante com maior profundidade.

Por volta de 1922, De Chirico transforma sua poética novamente. Abandona a pintura italiana renascentista e regressa ao seu grande modelo Arnold Böcklin. De Chirico é admirado por surrealistas por suas composições oníricas, nas quais a razão e a lógica são abolidas, e nas quais os elementos inconciliáveis entram em colisão. No entanto, os surrealistas não aceitam a transformação pósmetafísica de De Chirico, é como se o artista tivesse renegado sua própria poesia. Rejeitam seus novos trabalhos que, para os surrealistas, são tradicionais e reacionários.

52 CLAIR, Jean. "Maquinismo e Melancolia". In: GALERIES NATIONALES DU GRAND PALAIS, Mélancolie: Genie et Folie en Occident ...op.cit., p. 440 e seguintes.

${ }^{53}$ Idem.

${ }^{54}$ Idem. 
Apesar da crise com os surrealistas, De Chirico continua ascendendo na capital francesa. Muda-se para lá e aprecia a efervescência do espírito moderno da cidade. A iconografia elaborada em Paris durante os anos de 1920 se nutre de lembranças da Grécia onde passa sua infância. As obras são baseadas na nostalgia de um mundo arcaico e são caracterizadas agora por um vocabulário pictórico de ordem mais histórica e arqueológica. A melancolia presente em seus trabalhos encontra-se sustentada pelos elementos metafóricos, pela leitura dos mitos, pela alegoria personificada em Ariadne e, principalmente, por seu estado temperamental. O retorno ao passado torna-se mais radical e as reações das vanguardas são inevitáveis à obra de Giorgio De Chirico.

Ao renegar a avant garde, De Chirico é visto como um pintor conservador, ou seja, um "traidor da revolução artística". Questionador da arte moderna, o pintor se entrega ao estudo profundo da Renascença e à restauração do clássico. Esta posição o afasta da Pintura Metafísica e o aproxima das teorias estéticas nacionalistas de Marinetti e do retorno aos valores da arte antiga, em voga durante a ascensão do fascismo. À época, o Novecento italiano corresponde ao ufanismo político da Itália. Já Giorgio De Chirico assume uma postura extremamente individualista. Seus trabalhos encontram-se sob a orientação das leituras, particularmente as de Nietzsche e Weininger sobre a relação do simbolismo sexual com as formas geométricas.

De Chirico pouco se importa com a liderança cultural da Escola de Paris. $\mathrm{Na}$ verdade, critica severamente os artistas que se identificam com as "vanguardas", especialmente aos movimentos artísticos vindos de Paris. Em seu fazer artístico, nota-se, cada vez mais, uma interpretação original e romântica do classicismo e um grande interesse pela técnica dos antigos mestres renascentistas. Aprende os segredos da têmpera com o pintor russo Nicolau Locoff, com o pintor fiorentino Enrico Bettarini e também num manual alemão, de autoria de Berger, que trata da pintura em têmpera de Böcklin. 
Nicolau Locoff, que me explicou como muitas pinturas antigas, que parecem pintura a óleo são na verdade, têmpera graxa. A têmpera me inquietava, comecei a procurar receitas dessa técnica e por alguns anos pintei com têmpera... ${ }^{55}$

Em Paris, os surrealistas atribuem valoração à produção metafísica em detrimento dessa produção mais recente que busca a "tradição italiana". Em paralelo, De Chirico transfere-se de Roma para Paris, no final de 1925, e regressa, gradualmente, para uma linguagem visual similar ao antigo trabalho metafísico, que às vezes é interpretado erroneamente como surrealista. $\mathrm{Na}$ realidade, o artista ainda mantém a visão do mundo permeado pela "nostalgia do clássico". Talvez, a aproximação com a temática surrealista não tenha sido de forma acadêmica (no sentido de compartilhar as mesmas preocupações e utilizar métodos semelhantes), mas baseada no seu interesse pelas questões filosóficas contemporâneas.

As lembranças e o momento presente se fundem também nas séries de trabalhos posteriores, que retomam os temas do período metafísico como a relação dentro/fora e o efeito do estranho, obtido ao deslocar os objetos comuns ou tirando seus contextos familiares. O pintor coloca os "objetos intrusos" sobre as cenas semelhantes a ilhas em meio a um ambiente que lhe é estranho. De Chirico conta, muitas vezes, que esses motivos lhe foram inspirados por suas lembranças de infância (numerosas mudanças de casa na Grécia e noites passadas ao ar livre por medo de tremores de terra) que se misturam com as experiências em Paris (impressão causada pelos móveis nas lojas). Os componentes de uma estética da melancolia confirmam-se no repertório do artista, uma vez que remetem às leituras pessoais do artista sobre a modernidade por intermédio do passado.

Possivelmente, o ápice desse regresso ao passado concentre-se nas telas Musas inquietantes (1925) e Os Arqueólogos (1968) que retratam um mundo antigo, circundado por símbolos solitários em ruínas, evocando descobertas arqueológicas. As Musas Inquietantes caracterizam a série "manequins", que

\footnotetext{
${ }^{55}$ Idem.
} 
reinterpreta, de maneira inédita, o tema da familiarização da forma humana - o que o confere um efeito de estranhamento, da petrificação do corpo e da animação do mundo material. Já os "arqueólogos" são criaturas híbridas, às vezes seres humanos, bonecas e estátuas. Comparados aos manequins que povoam suas telas anteriores, estes personagens parecem mais vivos, mais físicos, menos isolados nos seus estranhamentos. A citação, a metáfora, o mundo antigo em ruínas, o emprego da perspectiva renascentista, os manequins e os objetos todos são elementos importantes para o repertório de Giorgio De Chirico e, acima de tudo, são os alicerces utilizados pelo pintor para a edificação de sua própria estética da melancolia. Contudo, a constatação desses fatos não é suficiente para a total compreensão de sua poética. Nesse momento, é exercício fundamental a análise de cada um desses elementos. Observar como o artista procede e quais seriam suas preocupações fundantes na sua erição melancólica.

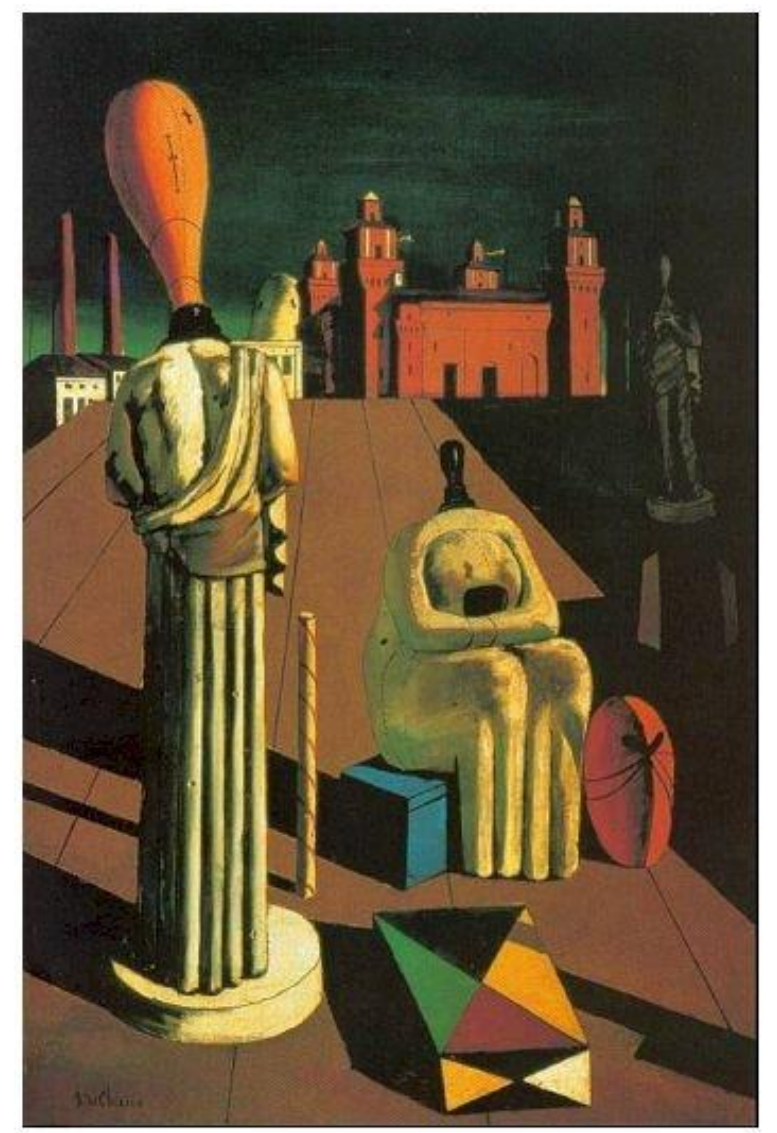

Giorgio De Chirico. As Musas Inquietantes, óleo sobre tela, (97 x $66 \mathrm{~cm}), 1925$, Galeria Nacional de Arte Moderna, Roma. Itália 


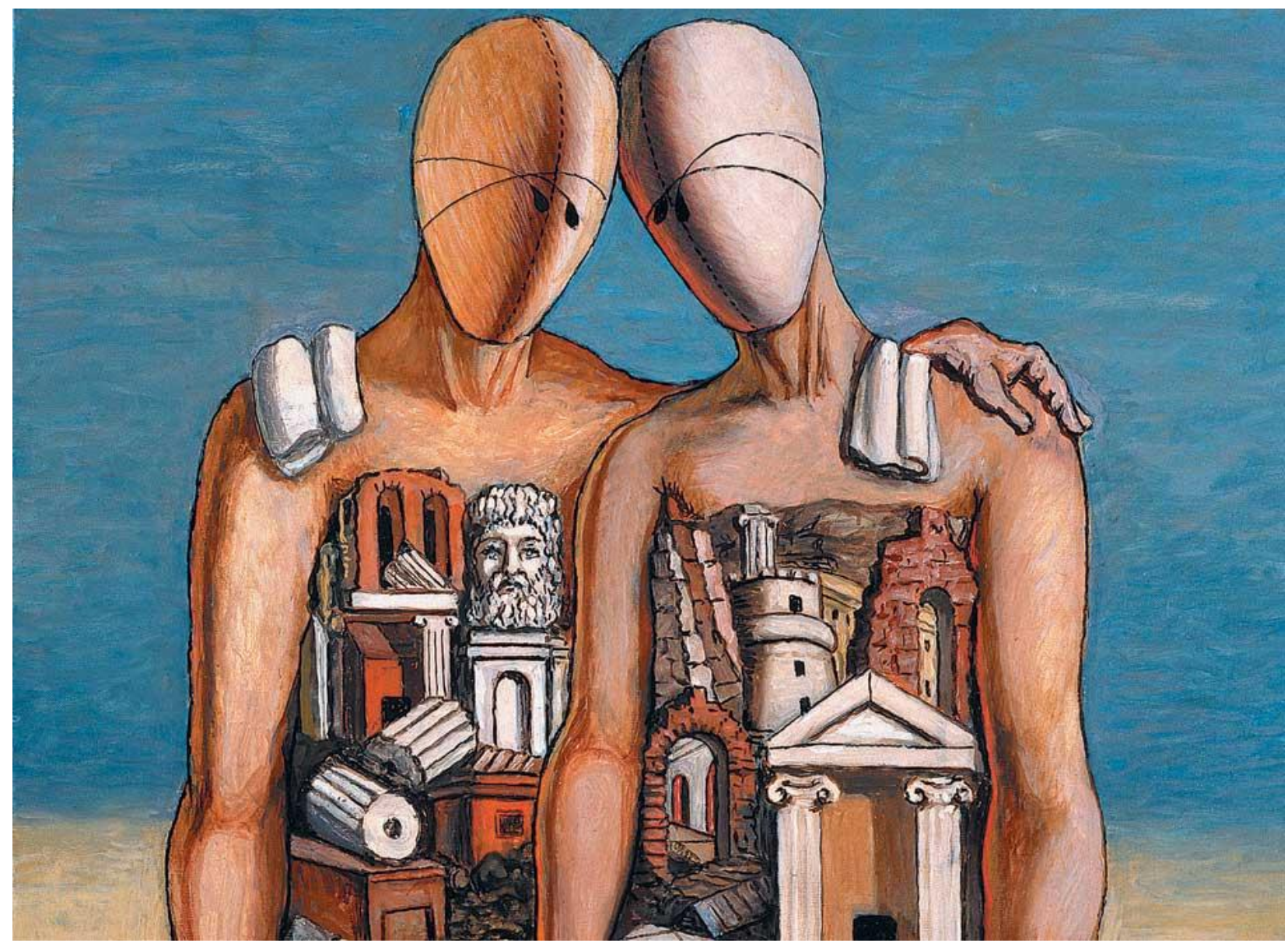

Giorgio De Chirico, Os Arqueólogos, (detalhe), óleo sobre tela, 1968 


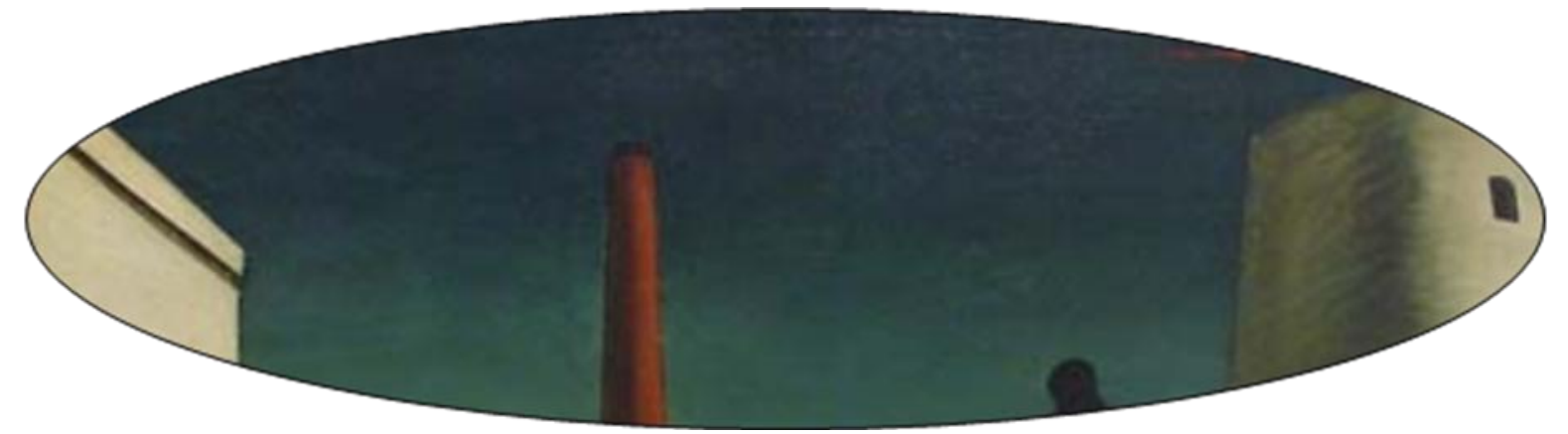

DE CHIRICO E "A SOLIDÃO DOS SIGNOS" 


\section{O "Poder da Ruína"}

A Pintura Metafísica criada por Giorgio De Chirico é composta, entre outros elementos, por uma variedade de símbolos. Segundo o artista, para que seja verdadeiramente imortal, uma obra de arte precisa abandonar, por completo, o limite do humano. Para tanto, é necessário extrair uma obra do ponto mais profundo de seu ser até atingir o silêncio - um lugar onde toda a presença se dá pela ausência. Elementos clássicos da pintura italiana, como o espaço em perspectiva e as arquiteturas urbanas, somados à alusão de lugares, como particularmente Ferrara e Turim, com suas amplas perspectivas, brancas e desertas, levam o artista a um mergulho em sua alma que, por sua vez, o conduz inevitavelmente a uma arte metafísica. Nessa busca por algo que está além do que se vê, antecipam-se os signos da Humanidade e a própria paisagem.

De Chirico se considera o "verdadeiro herdeiro" da tradição grecoromana e o único capaz de empregar com maestria a perspectiva renascentista. ${ }^{1}$ Estuda, com empenho, mestres da pintura italiana, tais como Rafael e Ticiano e acredita na técnica do desenho, na geometria e nos cálculos matemáticos para recriar o "enigma da vida". ${ }^{2}$ Em seus cenários desolados e estéreis, povoados por uma atmosfera de sonhos e mistérios, nos quais a convivência entre os elementos é inquietante, porém, harmoniosa, o vocábulo de De Chirico é construído por

\footnotetext{
${ }^{1}$ Segundo o comentário do pintor Albrecht Dürer, a expressão perspectiva significa 'ver através'. Essa impressão inédita de olhar-se para uma parede pintada e parecer que se vê para além dela, como se ali tivesse sido aberta uma janela para outro espaço (...). SEVCENKO, Nicolau. O Renascimento. São Paulo: Atual, 1994 (Discutindo a história), p. 32.

${ }^{2}$ Para o artista, os momentos metafísicos podem ser percebidos tanto por pintores como por escritores. Em sua concepção, Julio Verne é capaz de descobrir a metafísica de uma cidade como Londres em suas casas, ruas, clubes, parques e praças. A fantasmagoria de uma tarde de domingo londrina, a melancolia de um homem, como o personagem Phileas Fogg, em A Volta ao Mundo em Oitenta Dias, o registro de viagens imaginárias, inspiradas pelo progresso da ciência moderna, combinam uma forte dose de fantasia com dados científicos aparentemente plausíveis. BARBOSA, Paulo Roberto Amaral. Giorgio De Chirico no Acervo MAC USP ...op.cit., p. 32 e seguintes.
} 
intermédio da aplicação da luz e da sombra, mas, sobretudo, pelo uso da perspectiva. Em praças desabitadas, objetos do cotidiano, animais reais e mitológicos e seres sem rosto ou alma, o artista reafirma os valores grecoromanos - berço da civilização ocidental. A praça, vista como local da sociabilização, está vazia com o tempo de vivência congelado.

Giorgio De Chirico utiliza os símbolos, ou melhor, a "solidão dos signos" 3 - esse termo é propagado por diversos autores que tratam da obra do artista. Porém, é no trabalho de Jean Clair, Maquinismo e Melancolia, que o conceito torna-se explícito, como uso de ícones desconexos e sem relações diretas entre si. A "solidão dos signos" na produção Giorgio De Chirico evoca as ideias de Schopenhauer que define como "louca" aquela pessoa que perde a memória, ou seja, não há mais a possibilidade de estabelecer lembranças (relações) entre coisas ou fatos - ocorrendo o estranhamento do mundo material. Desse modo, há duas solidões presentes em uma pintura: uma, que pode ser chamada de "solidão plástica", configurada no prazer contemplativo provocado pela construção e combinação de formas e, a outra seria a vida da naturezamorta, considerada não no sentido de um gênero pictórico, mas como o espectral, passível de ser aplicada em uma figura supostamente viva. Esta segunda concepção seria a "solidão dos signos".

De acordo com o artista, o abandono das dimensões humanas é fator decisivo para a obra imortal. A gênese da Pintura Metafísica se dá pela ausência e pelo sentimento melancólico. A pintura clássica italiana, abordando a perspectiva e as arquiteturas urbanas, leva De Chirico a admitir que o espaço arquitetônico lhe desperta reflexões:

Na construção das cidades, na forma arquitetônica das casas, praças, jardins e passeios públicos, portos, estações ferroviárias, etc., existem os alicerces de uma grande estética metafísica (...). Meditei muito sobre esse problema da metafísica arquitetônica italiana e toda a minha pintura dos anos de 1910, 1911,1912, 1913 e 1914 preocupava-se com isso ${ }^{5}$.

\footnotetext{
${ }^{3}$ CLAIR, Jean. "Maquinismo e Melancolia". In: GALERIES NATIONALES DU GRAND PALAIS, Mélancolie: Genie et Folie en Occident...op.cit., p. 440 e seguintes.

${ }^{4}$ DE CHIRICO, Giorgio, "Sull'arte metafísica", Valori Plastici...op.cit.

${ }^{5}$ Idem.
} 
As cidades desoladas, fortemente geometrizadas e vazias (onde o tempo parece ter parado), dão a De Chirico sua autêntica essência, diferenciando-o dos demais artistas de seu tempo. A construção pictórica dos espaços arquitetônicos torna-se o fundamento da "estética metafísica". Já em suas primeiras telas é possível perceber sua admiração pelas edificações clássicas. A arquitetura se manifesta, como uma das belas artes, ${ }^{6}$ em sua dimensão de obra total - em seu volume operístico, durante toda a produção artística de De Chirico. O pintor direciona seu fazer artístico para a constituição de suas cidades. A teatralidade da arquitetura se molda em três dimensões até conseguir um olhar singular do espectador que contempla o espaço urbano.

Para o artista, entre os elementos arquitetônicos, os pórticos e as arcadas provocam impressões metafísicas. Para De Chirico, em uma arcada há algo incompleto que precisa e pode ser acabado, levando diretamente o espectador a um pressentimento. Essa interpretação das arcadas também serve para outros elementos geométricos presentes na arquitetura, como por exemplo, o triângulo que acarreta sensações de medo ou mal-estar. ${ }^{7} \mathrm{O}$ pintor registra, ainda que: "A árcade é uma fatalidade, ela tem uma voz que fala por enigmas cheios de uma poesia verdadeiramente romana". ${ }^{8}$ Pela primeira vez, a ideia de uma estética metafísica está fundada sobre a "experiência vivida" da arquitetura. O essencial não é a cópia da arquitetura, mas a forma de senti-la - uma aproximação que encontra eco nos lugares vazios e nas profundas séries de construções, nas arcadas obscuras e nas torres gigantescas, que caracterizam as pinturas de De Chirico a partir de $1911 .^{9}$

Na tela O Enigma de Um Dia II (1914), o artista cria um clima de mistério através da luz oblíqua que produz longas sombras nas edificações clássicas, típicas das cidades italianas. A tela, reconhecida pela crítica internacional, quando levada para a grande exposição de centenário de

${ }^{6}$ CASABAN, Consuelo Císcar (org.). El Siglo de Giorgio De Chirico: Metafísica y Arquitectura. Valencia: IVAM, 2007, p. 10 e seguintes.

${ }^{7}$ CLAIR, Jean. "Maquinismo e Melancolia". In: GALERIES NATIONALES DU GRAND PALAIS, Mélancolie: Genie et Folie en Occident...op.cit., p. 440 e seguintes.

${ }^{8}$ HOLZHEY, M. De Chirico (1888-1978): Le mythe moderne...op.cit.

${ }^{9}$ Idem. 
nascimento do pintor em Veneza, é considerada ícone da fase metafísica de De Chirico. ${ }^{10}$ Nela aparecem os símbolos inconfundíveis daquilo que o próprio artista denomina de "nostalgia do infinito": uma vasta praça deserta banhada em luz crepuscular, edifício antigo, estátua e, ao fundo torres medieval e moderna junto a um muro sem fim, onde corre uma minúscula locomotiva.

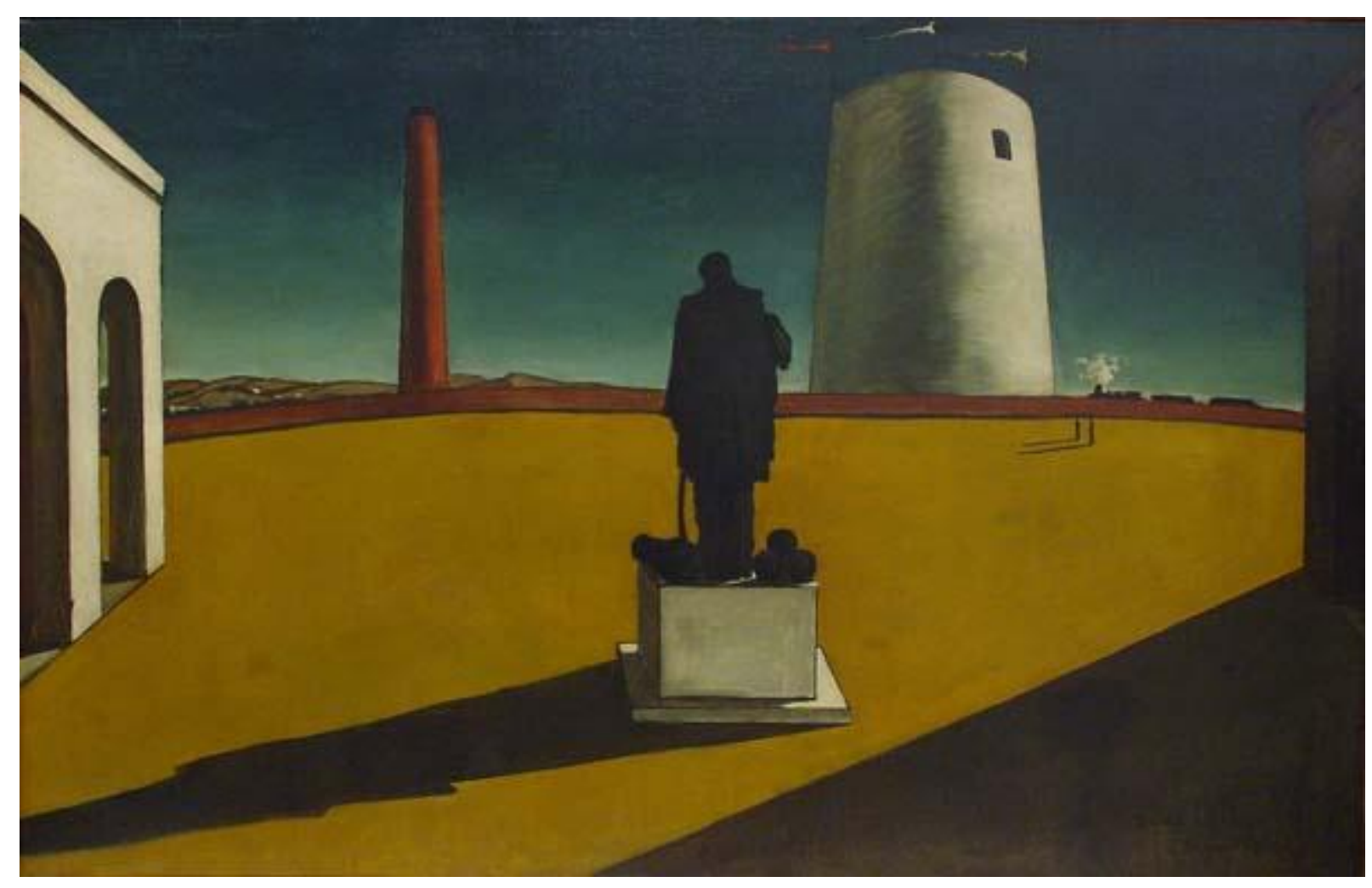

Giorgio De Chirico. O Enigma de Um Dia (II), óleo sobre tela (83 x $130 \mathrm{~cm}), 1914$.

Óleo sobre tela. Museu de Arte Contemporânea da Universidade de São Paulo, São Paulo (Brasil)

A herança estética greco-romana, entrelaçada à perspectiva renascentista, faz com que a arte de De Chirico alcance o estado mítico e profético - inerente à condição melancólica - sentimento desejado pelos românticos, desde o período de Baudelaire. $\mathrm{O}$ aspecto enigmático proposto pelo artista emprega a razão para retratar justamente o que ela não pode conhecer: uma realidade mais longe que a realidade, outra dimensão, o "enigma da vida". Provavelmente, a procura por novas formas de se expressar inicia-se em 1919, quando De Chirico tem uma inspiração ao visitar a Galeria Borghese, em Roma, e ao ver a tela de Ticiano

\footnotetext{
${ }^{10}$ MEDEIROS, Sérgio. "Enigma de De Chirico inspira filme brasileiro". O Estado de S. Paulo, 21 abr. 1994.
} 
Amor Sagrado e Amor Profano (1515). Conclui então que o segredo de uma obra de arte é, por conseguinte, a fascinação intrínseca à obra. Essa fascinação não tem sua gênese nos motivos, mas na pintura em si. Tal pensamento coloca em cena um tipo de "renascença" e a abordagem de temas bíblicos como, por exemplo, "o filho pródigo" que surge frequentemente nas telas do pintor. Em $O$ Filho Pródigo (1922), as proporções da praça italiana são harmoniosas e estão integradas em uma doce paisagem de colinas. Essa construção "renascentista" não tem mais nada de inquietante, contudo, mantém os personagens provenientes do mundo metafísico. ${ }^{11}$

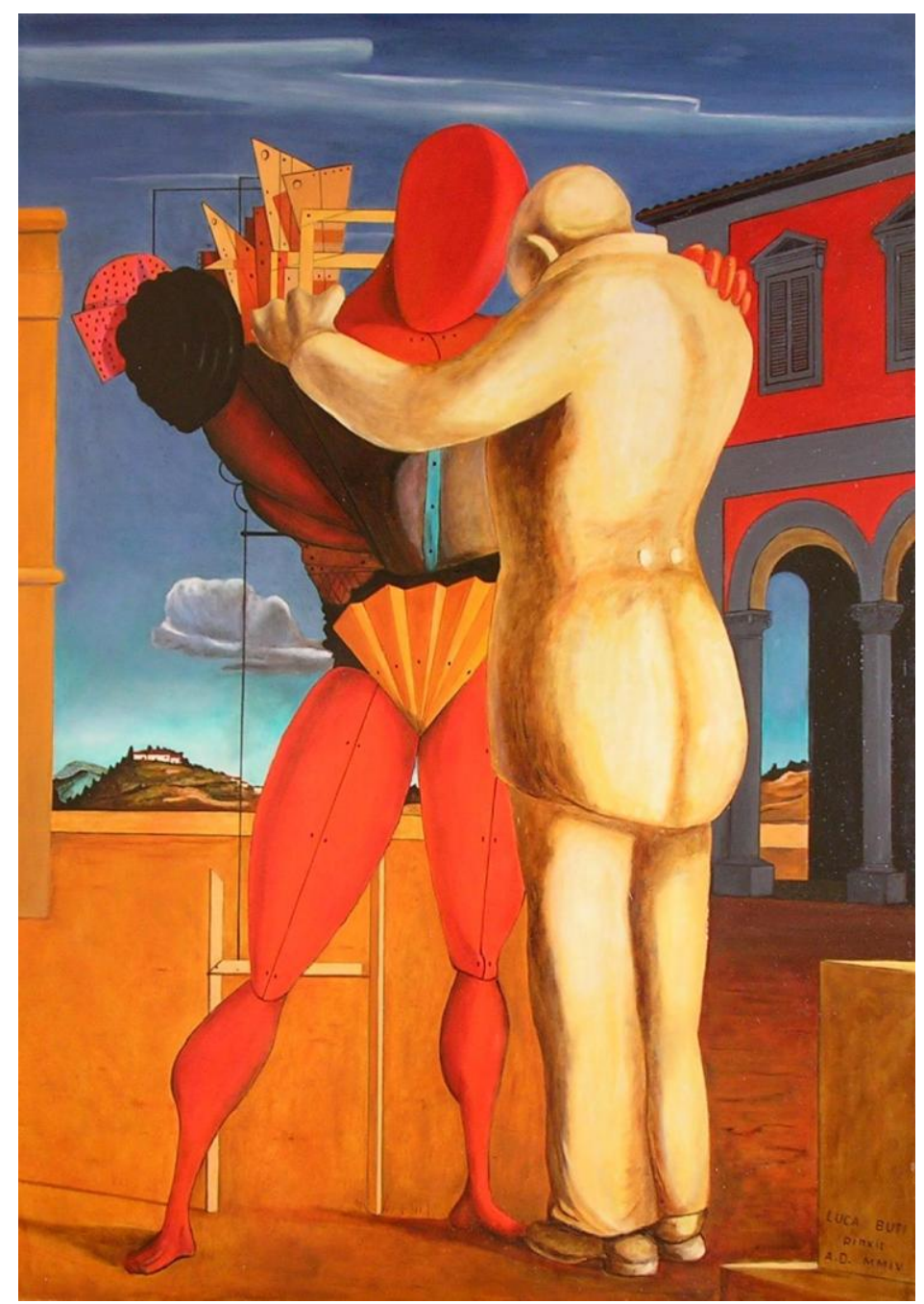

Giorgio De Chirico, O Filho Pródigo, tempera sobre tela, (87 x 59 cm), 1922. Têmpera sobre tela. Museu de Arte Contemporânea de Milão. Itália

${ }^{11}$ HOLZHEY, M. De Chirico (1888-1978): Le mythe moderne...op.cit. 
Entre 1910 e 1920, as vanguardas artísticas rompem a tradição renascentista. Essa tradição apoia-se, principalmente, na descoberta da perspectiva, isto é, numa representação da realidade que depende, simultaneamente, de uma ordem objetiva (a ótica) e de um ponto de vista individual (a sensibilidade do artista). A perspectiva impõe uma visão do mundo que é, ao mesmo tempo, racional e sensível. ${ }^{12}$ É papel da "avant garde" lutar contra o status quo da arte. Porém, os artistas metafísicos e, posteriormente, os surrealistas ressuscitam a perspectiva, para recriá-la como "perspectivas impossíveis", em ambientes irreais e com vários pontos de fuga.

O uso redundante que De Chirico faz de um motivo, nesse caso, a arcada, é característica deste tipo particular da perspectiva. Sabe-se que o artista inspirase em Otto Weininger sobre a significação estética deste tema: "No arco, há ainda algo de incompleto, que necessita e é capaz de preenchimento: ele deixa pressentir". ${ }^{13} \mathrm{O}$ arco de um círculo é, em relação à figura perfeita de um círculo, como a sombra em relação ao corpo material: uma realidade enfraquecida. E esta realidade enfraquecida, esta aparência de realidade, este pressentimento do real que ele manifesta, mas que nunca atinge; para existir precisa repetir-se, multiplicar-se; tornar-se, assim, estes obsessivos pórticos de De Chirico que significam sempre o perpétuo prolongamento de um mesmo que não chega a cumprir-se, o sussurro de um nome que não chega a ser anunciado, a gagueira de um sentido que não chega a acontecer. ${ }^{14}$

A inspiração para o uso da arcada em De Chirico deve muito às ruínas romanas presentes no cotidiano do artista. O "nomadismo cultural" da família De Chirico proporciona o conhecimento de diversas arquiteturas de cidades

\footnotetext{
${ }^{12}$ PAZ, Octavio. "Picasso: O Corpo a Corpo com a Pintura". Esse texto escrito originalmente para o catálogo da exposição Los Picassos de Picasso, que inaugurou em 1982, no Museu Rufino Tamayo (México) e editado no volume Sombras de obras, que reúne vários ensaios de Octavio Paz.

${ }^{13}$ CLAIR, Jean. "Maquinismo e Melancolia". In: GALERIES NATIONALES DU GRAND PALAIS, Mélancolie: Genie et Folie en Occident...op.cit., p. 440 e seguintes.

${ }^{14}$ Idem.
} 
dominadas pela presença de arcadas: Volos, Munique, Roma, Florença e Turim. ${ }^{15}$ No decorrer da Idade Média a multiplicidade desses elementos é base da arquitetura. De Chirico representa frequentemente o arco pleno, herdeiros das conotações simbólicas atribuídas a esses elementos arquitetônicos. Porém, os modelos empregados pelo artista aproximam-se aos arcos presentes em Munique. São colunas em estilo românico, maciças e de forte presença. Esses arcos surgem em diferentes ângulos, especialmente nas "pinturas-enigmas", datadas de 1914. Em uma primeira análise os arcos podem transmitir a harmonia e a proporcionalidade das construções gregas; a monumentalidade, a solidez do estilo românico e o triunfo da civilização ocidental. Em segunda análise, percebese que no repertório do artista, os arcos incorporam a tradição de sua pintura, reafirmados pela perspectiva de modo irreal.

Nessa "tradição pictórica", à primeira vista, o espectador tem a impressão de que as telas parecem obedecer às leis clássicas de equilíbrio e perspectiva, porém, um olhar mais atento denota as contradições. Por exemplo, em algumas obras, o vento leva as bandeiras para a esquerda e, simultaneamente, leva a fumaça do trem para a direita, ou ainda, a estátua e a construção que abriga a estrada de ferro ao fundo são retratadas a partir de múltiplos pontos de vista, entre outros elementos contraditórios. As projeções das sombras são irreais. O conjunto dos efeitos causa um "estranhamento" irremediável.

Isto porque na poética de De Chirico, a perspectiva é reintroduzida, a exemplo dos mestres da Renascença, mas essa não é mais um instrumento de ordem ou de integração, ela torna-se uma ferramenta de dispersão e de desordem.

\footnotetext{
${ }^{15}$ Um das mais famosas construções romanas é o Coliseum - um conjunto de estrutura utilitária com três ordens de arcos, uns sobre os outros, para sustentar os assentos de um grande anfiteatro interior. $\mathrm{O}$ arquiteto dessa construção cobre esses arcos com formas gregas: o primeiro piso é uma variante do estilo dórico, inclusive conservando as métopas e os triglifos; o segundo piso é jônico e, o terceiro e quarto com semicolunas corintias. Essa combinação de ordens gregas exerce enorme influência sobre os arquitetos romanos, surgindo o emprego massivo dos arcos. A construção de um arco com pedras independentes é uma proeza da engenharia e uma vez dominada a técnica, os arquitetos romanos podem partir para uma construção mais ousada como o Panteón (templo de todos os deuses), onde os pilares são prolongados, culminando com a aplicação de uma grande abóbada. A variação de arcos e abóbadas desenvolvidas a partir dessa experiência é impressionante. BARBOSA, Paulo Roberto Amaral. Giorgio De Chirico no Acervo MAC USP ...op.cit., p. 32 e seguintes.
} 
Desde então, em De Chirico, a ideia de metafísica associa-se à "solidão dos signos". ${ }^{16}$ Cada objeto, cada forma, cada delineamento do ser aparece doravante como fechado em sua própria solidão, como flutuando em um tipo de vazio semântico, "resíduo de um modelo que os deuses e os demônios jamais desertam". ${ }^{17}$ Nessa perspectiva, define-se uma relação inédita do homem com as coisas, que marca a condição do homem moderno e, acima de tudo, media a interação homem versus melancolia.

A melancolia moderna é o estado de uma consciência que é muito menos a de uma consciência abandonada do sentido de realidade, como Ariadne na obra de Giorgio De Chirico é abandonada por Teseu, do que uma consciência submersa. ${ }^{18}$ A consciência melancólica é aquela que sai dos vivos, do mundo dos humanos, para mergulhar no inerte, no mundo das coisas. ${ }^{19}$ No limite, é uma consciência que, em sua obsessão de morte, acaba por coisificar-se, ou seja, torna-se um objeto petrificado. A realidade inerte dos objetos torna-se o único refúgio, o único consolo e o encantamento diante da ameaça de seu desaparecimento. $^{20}$

A evolução do tema da melancolia na obra de Giorgio De Chirico e sua representação é aquela na qual o próprio artista torna-se objeto dentre os objetos, coisa dentre as coisas, fragmentos de um todo destruído, ruína material dentre as ruínas. Neste ponto de vista, vem à tona a frase de Walter Benjamin que, em seu ensaio sobre a origem do drama barroco alemão, escreve: "O único prazer que se permite o melancólico, e é um prazer poderoso, é a alegoria". ${ }^{21}$

A alegoria e a metáfora, com efeito, são procedimentos retóricos que, por excelência, autorizam esta petrificação ou esta reificação dos dados sensíveis do

${ }^{16}$ CLAIR, Jean. "Maquinismo e Melancolia". In: GALERIES NATIONALES DU GRAND PALAIS, Mélancolie: Genie et Folie en Occident...op.cit., p. 440 e seguintes.

${ }^{17}$ Idem.

${ }^{18}$ A vista de Arianna addormentata, uma cópia do original no Museu do Vaticano executada por Corneille Van Clève em 1688 do jardim Versailles (Giorgio conhecia a cópia no Museu Arqueológico de Florença) dá a ele um novo ponto de vista para a sua iconografia metafísica. Idem.

${ }^{19}$ Idem.

${ }^{20}$ Idem.

${ }^{21}$ BENJAMIN, Walter. Origine du drame barroque allemand, Paris: Flammarion, 1985. 
mundo. Esses instrumentais permitem continuar a viver num meio de um universo de rochas e ruínas, de um universo metafísico que é feito apenas de "signos solitários". 22 O sentido da melancolia em De Chirico, como já visto, origina-se do sentimento de que apesar das aparências exteriores de uma ordem plástica restaurada, nenhum saber global pode reatar-se a diversidade dos saberes locais. A unidade, a homogeneidade da arte antiga desaparece nesse contexto. $\mathrm{O}$ manejo da perspectiva, se percebe, trai este jogo espaço-temporal que, sob a aparência de uma ordem restaurada, descreve de fato as etapas de um espoliamento, leva os signos a uma privação. O espaço arquitetônico apresentase, mesmo que aparentemente restaurado, está em ruínas - escombros marcados pela subjetividade dos "signos solitários". Por vezes, destroços apresentam-se na obra de Giorgio De Chirico, dentro dos arqueólogos, ou seja, inseridos literalmente nos indivíduos - mas sempre surgem de modo marcante no repertório do artista.

Os símbolos arquitetônicos, constituídos pelas chaminés e torres, estabelecem um contraponto aos arcos de estilo românico. No entanto, as duas construções unem-se pela solidez e vigor. Nos trabalhos de De Chirico, a conexão entre os estilos arquitetônicos - clássicos (arcadas) e neoclássicos (torres e chaminés) - compõe um cenário de melancolia, muito próprio ao período do início do século XX. As torres e chaminés marcam a espacialidade da industrialização. Suas proporcionalidades monumentais para o plano da obra indicam o sentimento de abandono do homem moderno.

A herança greco-romana funde-se com o contexto urbano-industrial e nessa composição o humano é destituído de significado, ou levado a ser figura secundária, perante a arquitetura. Os únicos seres antropomórficos existentes, nesse mundo inconsciente, são manequins e estátuas - elementos também privados de humanidade, pois são desfigurados. Todo o conjunto assume uma impressão cenográfica e de dramaticidade teatral, onde a sobreposição dos elementos enigmáticos, aliados à iluminação, provoca inquietações. A

${ }^{22}$ CLAIR, Jean. "Maquinismo e Melancolia". In: GALERIES NATIONALES DU GRAND PALAIS, Mélancolie: Genie et Folie en Occident...op.cit., p. 440 e seguintes. 
melancolia, nesse mundo em ruínas, reside na coisificação do humano - os objetos representam a inércia do humano perante sua realidade moderna.

De Chirico busca incessantemente o real imerso na realidade - o que está além das aparências. Para ele, a experiência diária aliena os sentidos. É necessária a reflexão permanente sobre morte/vida e a captura da aparência metafísica - algo que está além da compreensão original das coisas - um conhecimento mais profundo do que o real, somente revelado em momentos efêmeros, nos quais a liberdade do sonho atravessa o estado de vigília e dá sentido ao mundo. Assim, a pintura metafísica contém o insight da realidade, a redescoberta de um tempo passado, das horas perdidas, da presença latente nos grandes espaços e na intimidade dos interiores. ${ }^{23}$ As representações dos espaços arquitetônicos, criadas por De Chirico, carregam a aparência misteriosa que está escondida atrás dos objetos heterogêneos - dos "signos solitários".

Faz-se oportuna, então, uma reflexão mais apurada sobre quais são esses "signos solitários": quais são os seus valores semânticos no fazer artístico de Giorgio De Chirico? E, sobretudo, quais são as interações destes com o sentimento melancólico presente nas obras?

${ }^{23}$ GUERREIRO, Walter de Queiroz. Metafísica além da vigília. Especial para o Anexo. www.anexo.com.br. Acesso em 20 de julho de 2004. 


\section{As Metáforas Plásticas}

De Chirico agrega metáforas plásticas, ao seu trabalho, extraídas do seu contexto e, sobretudo, espelhadas a partir de sua vivência. Como um homem do século XX, o artista percebe as transformações ocorridas ao seu redor e deixa em sua produção - particularmente, nas obras do período da pintura metafísica, incluam-se nesse conjunto as "pinturas-enigmas" - as marcas do mundo urbanoindustrial que emerge a partir da presença da máquina. Na década de 1910, os futuristas elegem o "carro" como símbolo da modernidade. A escolha se justifica. Para esses artistas, nada altera tanto a conformação social. Através das condições propostas pelo uso do carro, o ritmo da vida é acelerado - o carro nada mais é do que a presença nas ruas dos fatos que compõem a segunda revolução industrial em vigor à época. $\mathrm{O}$ "tempo da máquina" dissemina-se das linhas de montagens para as ruas: proletários e burgueses convivem e partilham suas vidas com a presença invisível da máquina. O relógio da fábrica presente na obra $O$ Enigma da Hora (1910/1911) controla as ações da vida e, ao mesmo tempo, o congelamento do tempo mostra o contingência do ser.

Para De Chirico, a "máquina", presente em suas memórias, tem seu potencial explorado pela imagem do trem. Deve-se recordar aqui que o pai do artista está envolvido na construção de ferrovias e que a família está sempre em constante movimento, utilizando-se desse meio de transporte. O motivo do trem passando no horizonte, constante em diversas obras, alia um plano biográfico a um plano simbólico. A estação de trem é ligada à memória afetiva do pintor, cujo pai é engenheiro, proprietário e presidente de uma empresa construtora de ferrovias em Volos (Grécia). Além disso, evoca as figuras da viagem, do deslocamento e do viajante.

Nos primeiro enigmas estão presentes: o barco à vela, a figura dos argonautas, o trem - todos os ícones do pintor-poeta viajante na "Paris Industrial”. É a reafirmação do artista que coloca, em sua poética, lembranças da 
infância: a profissão do pai, as numerosas viagens, o caminho de ferro que passa atrás do muro do jardim da família, na residência em Volos. ${ }^{24}$ A estrada de ferro simboliza a viagem da vida em geral. No mito dos Argonautas, os heróis partem em busca do velocino de ouro. A viagem é associada à partida - a eterna ruptura com o estabelecido e a espera pelo o que virá. A própria biografia do artista encontra no caminho de ferro sua formulação da "Argos Moderna".

Enfatiza-se, ainda, que o movimento sugerido pelo trem está em contraposição com o sentimento de "perpetuação do instante" expresso nitidamente na obra O Enigma da Hora (1910/1911). Esse exercício de forças antagônicas é mais executado em algumas telas. Na Série dos Enigmas, a figura do trem surge somente em O Enigma de Um Dia II (1914) - fase final dessa série. ${ }^{25}$ Porém, esse elemento permanece em outros trabalhos do mesmo período e nas obras que inauguram a fase neometafísica, por volta de 1970.

Como já mencionado, o emprego de metáforas na poética de De Chirico é uma resposta imediata ao seu tempo. Um período que as "vanguardas artísticas" inauguram como um "novo momento", rompendo com a tradição. Em especial, o Futurismo almeja sair do atraso por intermédio dos desdobramentos ocasionados pelo emprego da máquina. De Chirico não se ajusta a este ideal. O artista tem ciência da necessidade de "uma nova estética", mas entende que para isso não precisa destruir as tradições greco-latinas que orientam sua vida. A fascinação pelo esquema mitológico invade não somente a poética visual de Giorgio De Chirico, mas também, sua vida transforma-se em algo mítico. A produção do pintor revisita o legado cultural (a mitologia helênica e latina). Através de uma "reciclagem histórica", o artista organiza imagens canônicas, selecionadas durante os séculos da História da Arte, assumindo seus maiores estereótipos: as estátuas e os templos gregos; a perspectiva quatrocentista; as opulentas formas do Renascimento. ${ }^{26}$

\footnotetext{
${ }^{24}$ BARBOSA, Paulo Roberto Amaral. Giorgio De Chirico no Acervo MAC USP...op. cit., p. 66 e seguintes.

${ }^{25}$ Idem.

${ }^{26}$ Idem.
} 
A fase metafísica busca o legado histórico cultural greco-latino. Em um momento posterior, apresenta uma retomada dos grandes mestres do Trecento e Quatrocento, usando a temática (retratos e autorretratos, paisagens, naturezasmortas e pela técnica, que posteriormente denomina-se da "retomada da pintura de cavalete"). Além disso, na última fase de sua produção, Giorgio De Chirico descobre a possibilidade de revisitar a si mesmo, reciclando sua própria época precedente, em especial a fase metafísica de 1910 a 1917 - algo também melancólico, uma vez que pretende resgatar o que é considerada, pelos críticos mais ácidos, sua melhor fase. ${ }^{27}$

Em Torno de De Chirico: "Diagramas" Possíveis, dissertação apresentada por Marise De Chirico, na UNESP, em 2000, é um trabalho que discorre sobre a apropriação de personagens míticos na obra de Giorgio De Chirico. Para essa autora, De Chirico cria uma "cosmogonia pessoal", quando descontextualiza as narrativas mitológicas e transporta para sua trajetória pessoal, experimentando a força vital dessas personagens em si mesmo - imagens referenciais, com alto potencial simbólico, sensorial e, ainda, associadas à sua biografia - percebe-se que o artista cria uma dimensão nova para tais narrativas.

Dessa forma, Marise De Chirico identifica três categorias de personagens míticas ${ }^{28}$ :

\footnotetext{
${ }^{27}$ As cópias realizadas pelo próprio De Chirico, a partir de 1940, são um dos maiores obstáculos para valorização das obras dos períodos posteriores. A contribuição do artista para o mercado dos falsos é ainda discutida: se simplesmente pretende fazer circular os quadros com datas alteradas, para fins comerciais, ou se isso faz parte de seu espírito lúdico e paródico de brilhante estrategista. Em julho de 1946, De Chirico declara falsa toda sua produção datada entre 1910 e 1920, exposta na Galerie Allard, em Paris. Começa a polêmica sobre a falsificação de sua obra, que perdura até mesmo depois de sua morte, posto que Isabella Far reafirma as mesmas irredutíveis posturas de seu marido. Mesmo que a memória falta, o reconhecimento de um quadro ou de uma escultura sempre poderá ser feito por ele ou por mim. Ninguém se engana diante de sua criatura (FAR, Isabella. Caderno B, Jornal do Brasil, janeiro de 1988). Uma das tentativas de catalogação oficial da obra é feita por Cláudio Bruni-Sakraischilk, marchand e um dos organizadores da Fondazione Giorgio e Isa De Chirico, que pretende, em 8 volumes e quase dez anos de levantamento, legitimar a obra. Essa tarefa não é suficiente, pois o próprio Cláudio Bruni acaba sendo envolvido na questão dos falsos de De Chirico. DE CHIRICO, Marise. Em Torno de De Chirico: "Diagramas" Possíveis. São Paulo: UNESP, 2000 (Dissertação de Mestrado), p. 4 e seguintes.

${ }^{28}$ Idem, p. 33-35.
} 
- Personagens Identificáveis - Jasão e os Argonautas; Dióscuros: Castor e Pólux; Ariadne; Heitor e Andrômaca; Hipólito; Orestes e Pílades; Minotauro; Penélope e Telêmaco; Orfeu; as Sibilas; Ganimedes; Aquiles; Júpiter; Paris; Electra; Cavalos com Aigrettes e Mercúrio; Édipo e a Esfinge; as Musas; Antígonas; Cavalos antigos de Apolo e, Leda.

- Recomposição das personagens das mitologias - Cavalos; Gladiadores; a Virgem do Tempo; Musa da Lírica; Musa da Música; Musa da Antiguidade; Musa da Arqueologia; Musa do Teatro e Musa da Literatura.

- Criações de Giorgio De Chirico - os Arqueólogos; o Trovador, o Consolador; o Pintor; as Musas Inquietantes; Manequins Coloniais; o Poeta Solitário; o Contemplador; o Grande Metafísico.

Da recorrência de temas e personagens na produção artística de De Chirico, destacam-se as imagens dos Cavalos. ${ }^{29}$ De Chirico julga-se herdeiro dos ideais da cavalaria, oriundos pela descendência paterna, que desperta profundo respeito pelos valores de lealdade, crenças e compromissos de honra. A figura do cavaleiro, que perpassa pela literatura medieval e adentra a literatura moderna, encarna a figura do senhor de sua montaria, senhor de seu próprio destino, serviçal leal do rei, devoto à dama eleita, ou líder de uma guerra. A autoridade intrínseca à figura do "senhor" fornece os subsídios necessários para a obtenção dos objetivos do pintor: alcançar a áurea mítica de "ser superior" (deus, rei, pátria, missão). No caso específico de sua pintura, atingir a "grande pintura" - o destino a se cumprir. $\mathrm{O}$ sonho do cavaleiro é o ideal de figurar na História como um mestre da grande pintura - ideal somente possível a partir da crença de pertencer a uma rara humanidade de caráter moral muito elevado e, de certo

\footnotetext{
${ }^{29}$ O arquétipo do cavalo e do cavaleiro percorre parte da obra de Giorgio De Chirico. Sua trajetória inicia-se em seus primeiros trabalhos nas praças italianas e nas figuras equestres das estátuas, passa pelos cavaleiros, incluindo a representação dos Dióscuros e atinge total emancipação, nos cavalos à beira-mar, correndo libertos, ou simplesmente, retratados nas fontes, com crinas ao vento e olhares ctonianos. Idem.
} 
modo, sagrado. Interpreta-se, ainda, a figura do senhor como a imagem literária do "príncipe melancólico", tal como, Hamlet - o mal-estar encarnado na postura da nobreza que busca um tempo passado.

Para De Chirico, sua "trajetória mítica" inicia-se quando o artista, ainda jovem, deixa Volos a bordo da "Argo" na companhia de seu irmão Andrea, rumo ao efervescente cenário cultural parisiense. Os irmãos De Chirico aportam munidos de toda a educação oitocentista e enriquecidos pela recente experiência de aprendizado em Munique. Em Paris, são rapidamente aceitos e introduzidos por Guilaume Apollinaire na "avant garde" como os Dióscuros, Pólux e Castor, mito que os irmãos De Chirico revivem. ${ }^{30}$ Neste ponto, cabe lembrar que os Dióscuros estão presentes no Mito dos Argonautas e são os preferidos de Zeus. $\mathrm{Na}$ "mitologia pessoal", dos irmãos De Chirico, Guillaume Apollinaire personifica Orfeu, tornando-se arauto da nova arte. ${ }^{31}$ Os Dióscuros (Giorgio e, agora, Alberto Savinio) afastam-se dos cubistas, dos futuristas e principalmente dos surrealistas. Giorgio De Chirico realiza pesquisa pictórica aprofundada, em busca do que acredita ser seu destino: transformar-se no legítimo representante da pintura dos grandes mestres. A fase dos gladiadores, dos cavalheiros nus, com seus cavalos à beira mar representa esse comprometimento do artista. De Chirico encarna Pólux, guerreiro, cavaleiro, domador de corcéis, de natureza divina, por

\footnotetext{
${ }^{30}$ Os irmãos gêmeos Castor, o domador de cavalos e Pólux, o lutador, nascidos do amor de Zeus e Leda são heróis dórios por excelência. Castor é morto em batalha e seu pai vinga sua morte, fulminando Ida, o assassino, com um raio e oferece a Pólux a imortalidade. No entanto, Pólux não a aceita, enquanto Castor permanece nos Infernos. Assim, Zeus lhe permite ficar um dia entre os deuses e um dia nos Infernos para sempre. Outra versão afirma que os dois irmãos ficam nos céus, formando a constelação de Gêmeos. Dentre muitas batalhas, feitos heróicos e lutas atléticas - nas quais, Castor tem por especialidade agonística a corrida e Pólux, a luta - os dois gêmeos são integrantes da expedição dos Argonautas, a tripulação da nau que parti sob o comando de Jasão para recuperar o velocino de outro. Conta-se que durante a expedição, Zeus manifesta sua predileção pelos irmãos, pois, durante uma tempestade no mar da Cólquida, uma chama desce do céu e fica por cima da cabeça dos Dióscuros. Essa é a origem do fogo de Santelmo, que anuncia aos marinheiros o fim das tempestades. Os Dióscuros são venerados em toda a Grécia como divindades dos navegantes e da hospitalidade. DE CHIRICO, Marise. Em Torno de De Chirico: "Diagramas" Possiveis... op. cit.,p. 71.

${ }^{31} \mathrm{O}$ nome Orfeu, de origem egípcia e fenícia, é composto de aur (luz) e raphae (cura, salvação). Orfeu é aquele que traz aos homens luz e verdade. Orfeu não está morto. Os Orfeus são muitos e renovam-se. No mito, a contribuição de Orfeu é decisiva na empreitada dos Argonautas, pois sem evocar com sua lira aos deuses, a Argo não teria ultrapassado uma terrível tempestade. Idem, p. 86.
} 
ser filho de Zeus. Contudo, sofre com a morte de Castor (Savinio). De Chirico lamenta que o trabalho do irmão não tenha sido reconhecido como merecia ser.

O destaque das metáforas plásticas aliado à melancolia é Ariadne. Presente nas obras Melancolia (1912) e em Melancolia de uma Bela Tarde (1916), a figura da mulher petrificada em posição reclinada, cabeça apoiada por uma das mãos e pensativa, remete à imagem "clássica" da melancolia. Esses trabalhos iniciam-se por volta de 1912 com oito pinturas do mito grego de Ariadne. Nesses trabalhos, Giorgio De Chirico retrata uma estátua da princesa Ariadne reclinada em uma praça deserta. Segundo a lenda clássica, Ariadne, filha de Pasífae e Minos, rei de Creta, apaixona-se por Teseu, o herói ateniense. Dando-lhe um pedaço de fio de seda, a princesa o ajuda a escapar do labirinto em que o Minotauro vive. Teseu promete casar com Ariadne, durante sua viagem para Atenas, mas ao invés disso, ele a trai, abandonando-a na ilha deserta de Naxos. Posteriormente, ela é resgata por Dionísio. ${ }^{32} \mathrm{O}$ teor melancólico da história atrai a atenção de muitos artistas clássicos que, normalmente, retratam a princesa adormecida sobre praias vazias. Para De Chirico, a princesa abandonada é sua grande metáfora. Ela representa o passado clássico de sua terra natal.

Ariadne também é apontada por Nietzsche como sendo uma figura simbólica com relevância contemporânea. Para Nietzsche, o labirinto do mito grego pode ser equiparado, em termos contemporâneos com a complexidade dos enigmas da vida. O segmento, segundo Nietzsche, é uma necessidade na vida, permitindo um caminho através da confusão da vida. Para o filósofo, a princesa proporciona a solução para a fuga do labirinto. A primeira representação de Ariadne, realizada por De Chirico, acontece em Paris - quando o artista está intensamente solitário. Ariadne torna-se um símbolo de exílio e de perda. As obras que têm sua marca ressoam a solidão dos despossuídos. Na obra de Giorgio De Chirico, dezoito trabalhos se relacionam com o tema de Ariadne. Há uma continuidade entre essas pinturas, como já dito, iniciada nos primeiros anos em Paris - antes da I Guerra - e as obras posteriores, criadas quando do abandono da

\footnotetext{
${ }^{32}$ www.studio-international.co.uk/painting/Chirico.asp. Acesso em 23 de dezembro de 2010.
} 
arte moderna em favor dos grandes mestres. Todas se transformam em metáforas da busca do artista pelo conhecimento e aperfeiçoamento da prática da pintura.

Diferente do classicismo canônico - que aponta para uma época, na qual fé, conhecimento e prática são unificados, dando feição eclética à obra - na produção de De Chirico, a ciência, a filosofia e as diferentes fontes caminham em paralelo e causam o "estranhamento". Revela-se um profundo sentimento melancólico frente à modernidade. Simultaneamente, os motivos clássicos são mesclados aos elementos modernos e filtrados por uma sensibilidade contemplativa voltada às realidades dos tempos atuais. Talvez, seja necessário, ainda, levantar uma hipótese quanto à aparição do tema do manequim metafísico. Há grandes especulações sobre as fontes possíveis de sua iconografia. Diversos autores trabalham sobre as possibilidades abertas por esse signo, contudo, nesse estudo, levanta-se a vertente sobre a desumanização de suas figuras - o humano revertido em objeto - a máxima da expressão melancólica de De Chirico.

Dessa forma, a face, sem feições, poderia ser um símbolo do próprio artista, representado como um clarividente assim como, as musas que dão acesso a um mundo de ambiguidades, implicações, conotações, associações, ideias, qualidades e funções. O artista é aquele que detém, precisamente, a memória, a cultura e a tecnologia do passado. Nota-se, no entanto, que o corpo deste manequim é, às vezes, composto por diversas figuras planimétricas e estereométricas. Orna-se de diversos emblemas que tradicionalmente comparados à figura da mulher ou do Anjo de Dürer, significam a arte da geometria, o esquadro e a régua. Nesse contexto, não causaria estranheza indagar se De Chirico não teria a ideia de realizar uma anamorfose da melancolia.

Contudo, o sentimento melancólico expresso pela estética empregada por Giorgio De Chirico em seus trabalhos não reside somente em seu temperamento, suas leituras, suas metáforas e "signos solitários". A expressão melancólica está, também, na atmosfera presente em cada tela - no jogo de luz e sombras que projeta em seus espaços pictóricos. 


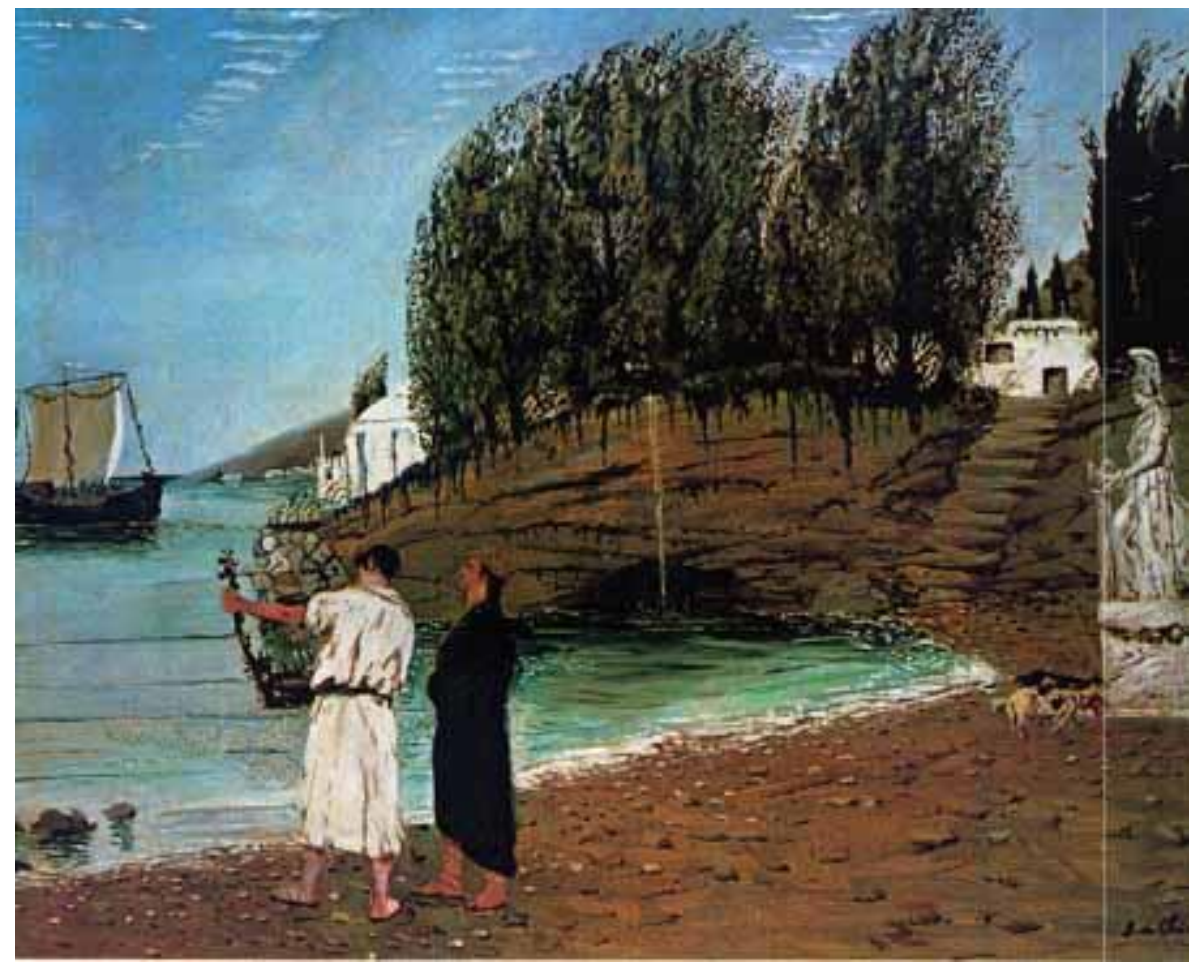

Giorgio De Chirico, A Partida dos Argonautas, óleo sobre tela (73 x 92 cm), 1909. Coleção Particular

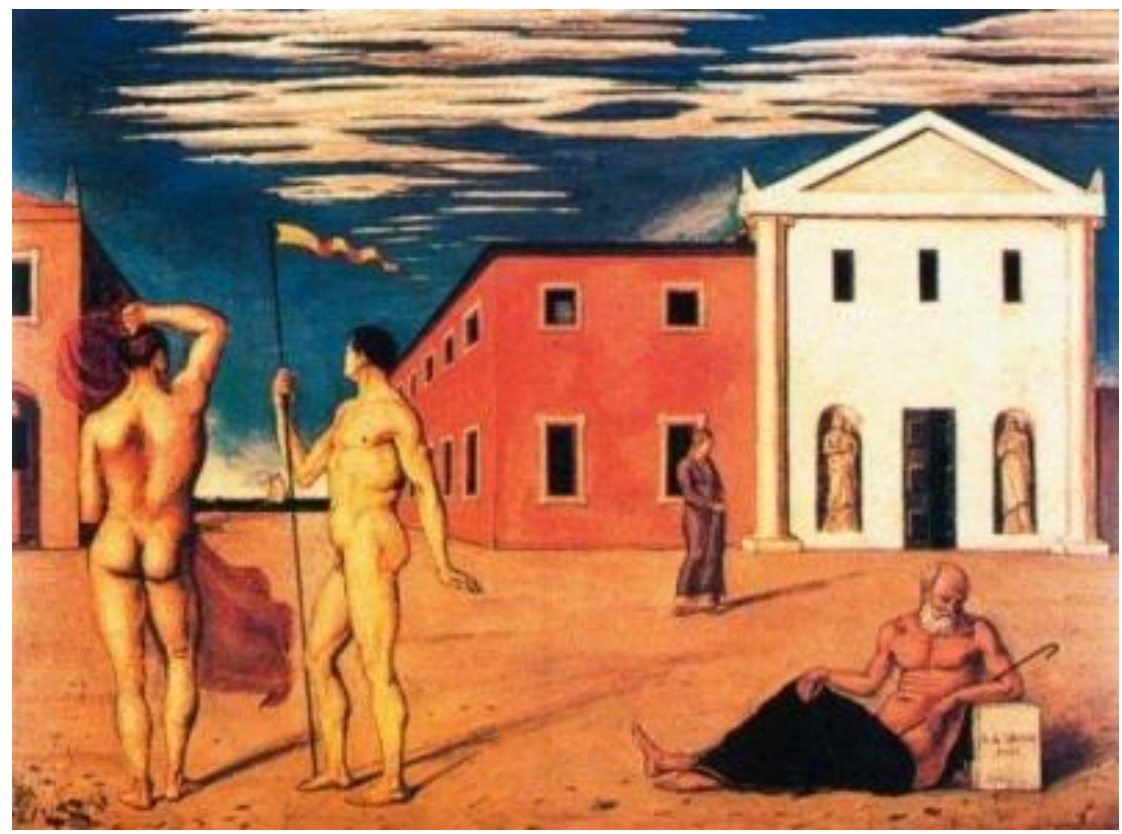

Giorgio De Chirico, A Partida dos Argonautas, óleo sobre tela, $(70$ x $80 \mathrm{~cm}), 1921$. Coleção Particular 


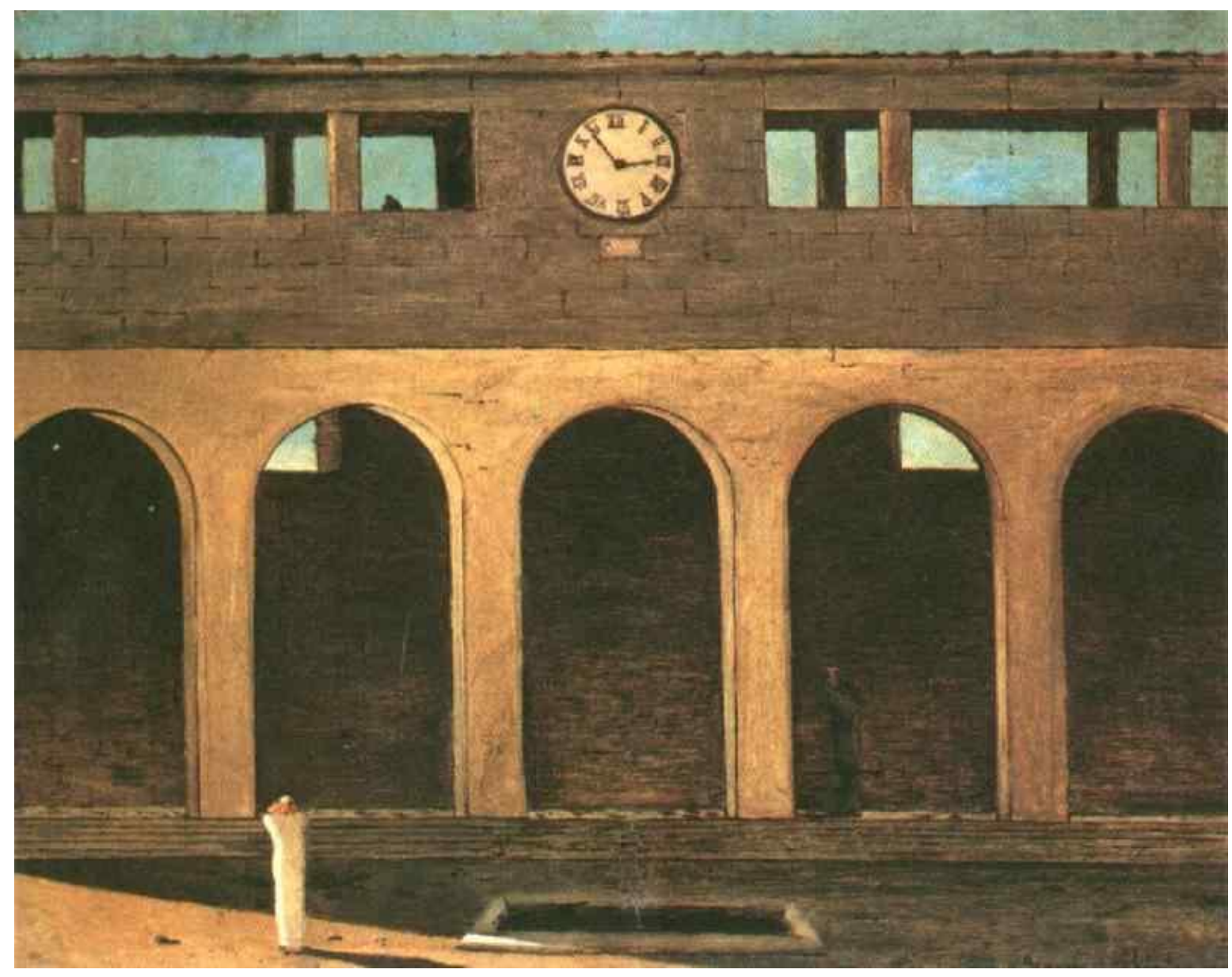

Giorgio De Chirico, O Enigma da Hora, óleo sobre tela, (55 x 71 cm), 1910/1911. Coleção Particular. 


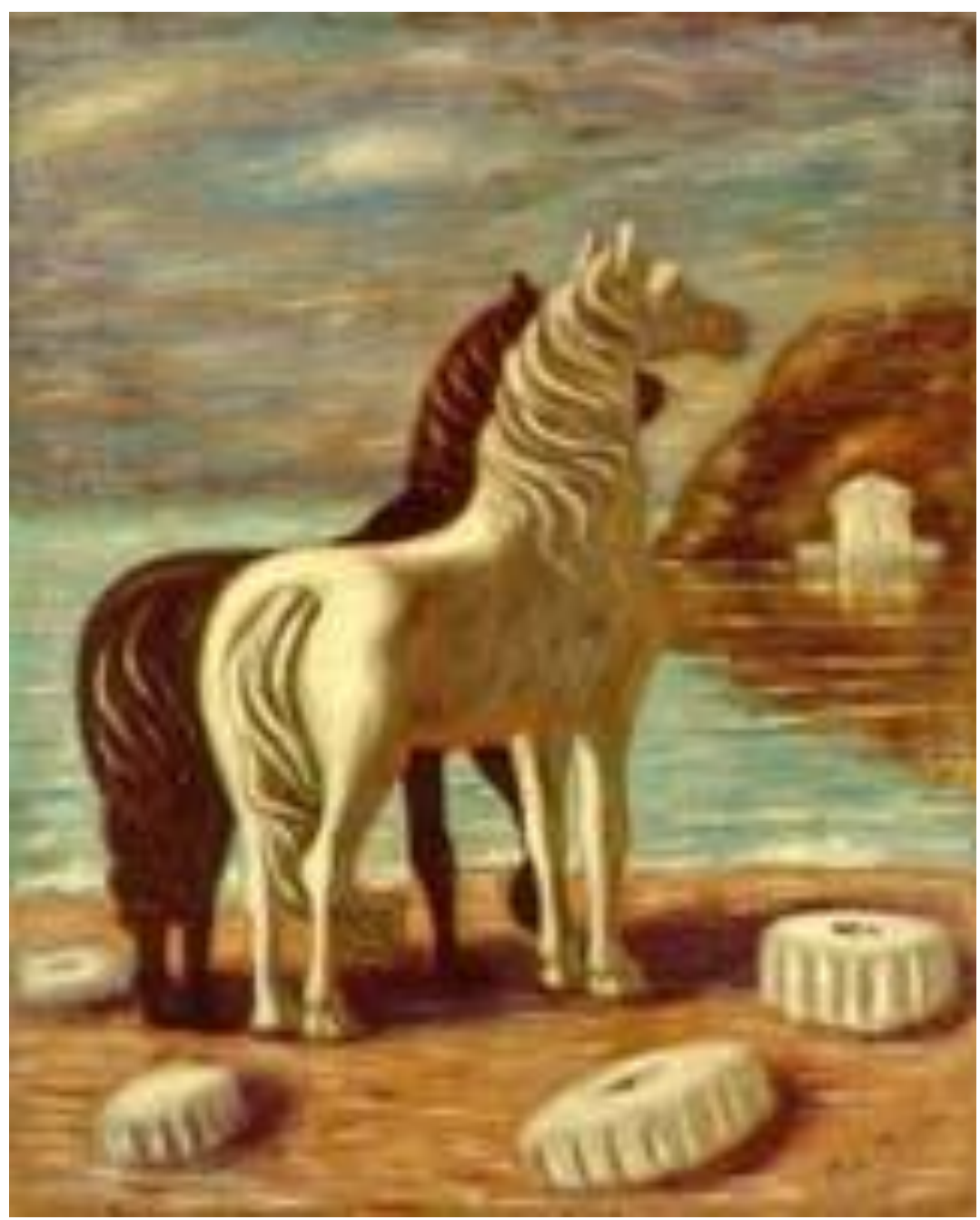

Giorgio De Chirico, Cavalos à Beira Mar, óleo sobre tela, (47,0 x 45,6 cm), 1932/1933. Museu de Arte Contemporânea, São Paulo. Brasil 


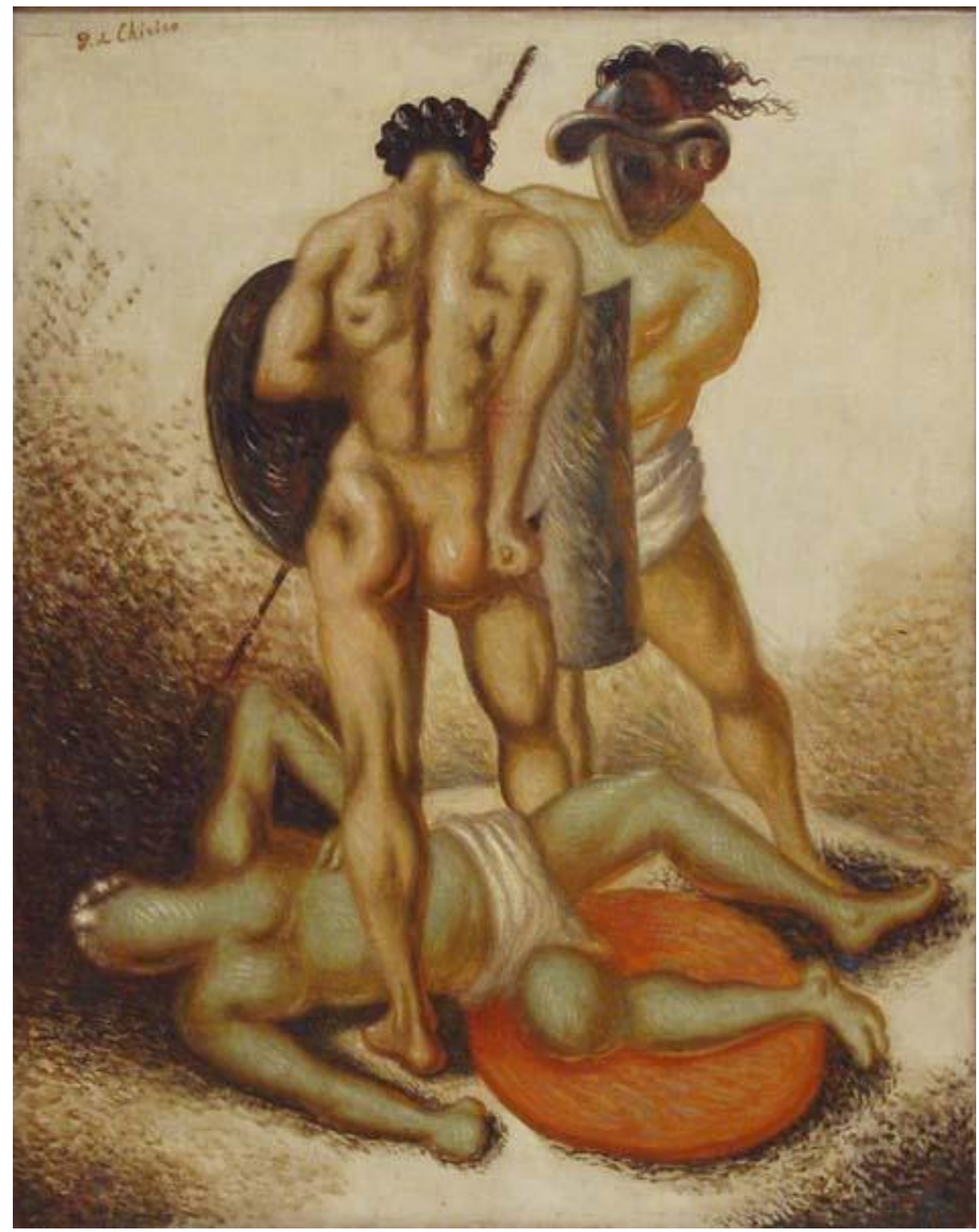

Giorgio De Chirico, Gladiadores, óleo sobre tela, (74,7 x 59,8 cm), c. 1935. Museu de Arte Contemporânea, São Paulo. Brasil. 


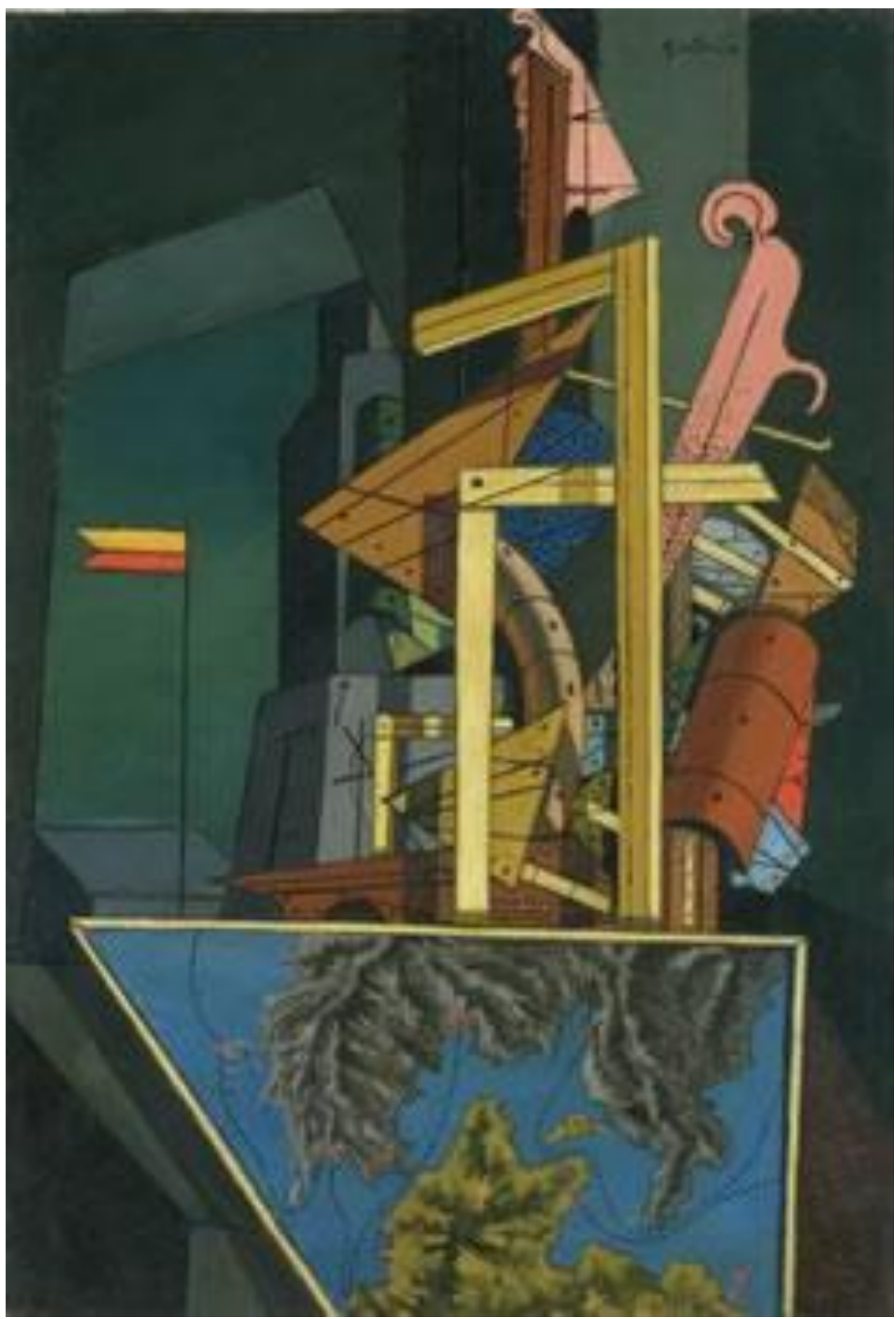

Giorgio De Chirico, Melancolia da Partida, óleo sobre tela, (51,8 x 36 cm), 1912. The Tate Gallery, Londres. Inglaterra 


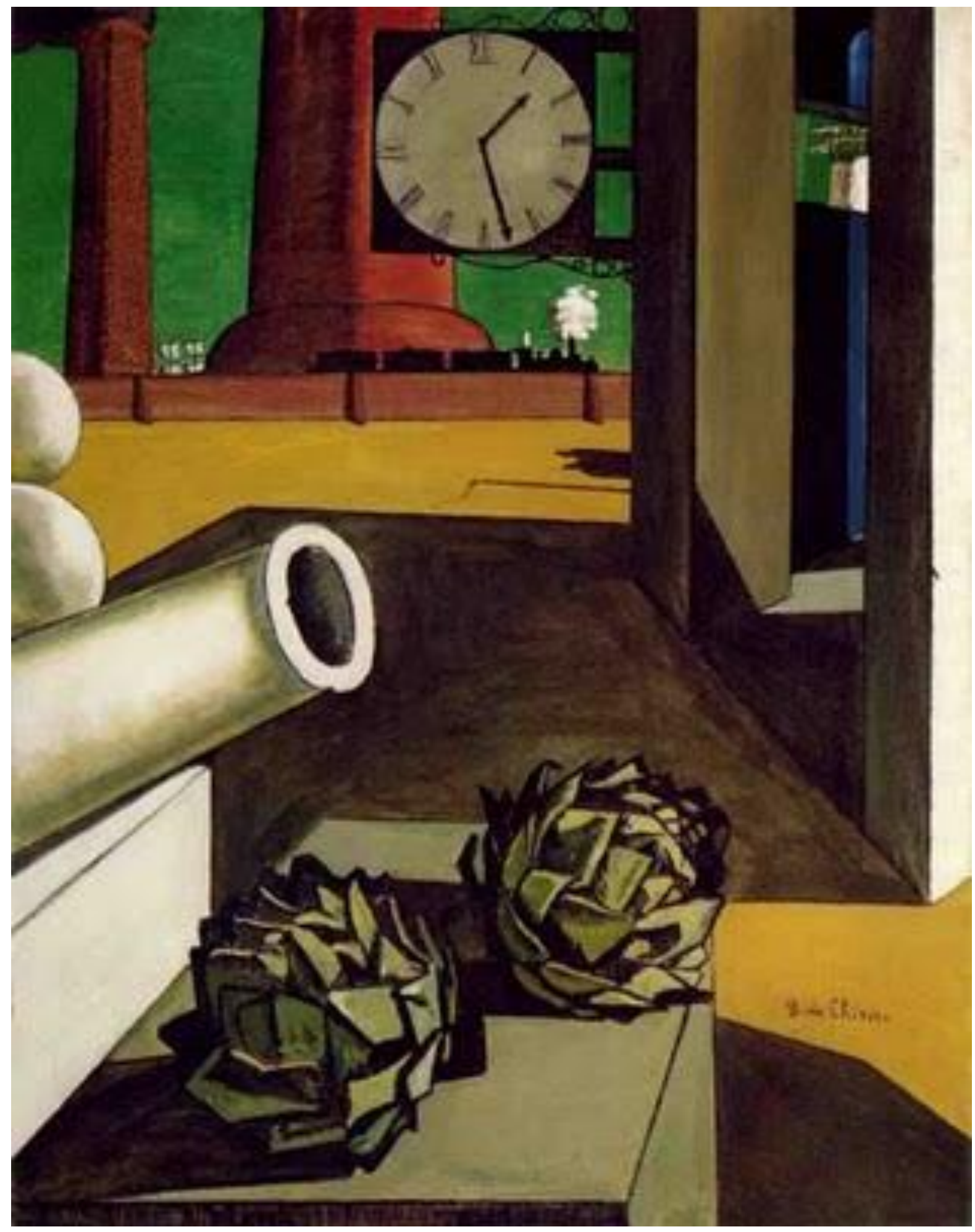

Giorgio De Chirico, Conquista do Filósofo, óleo sobre tela (125,1 x 99,1 cm), 1914. Instituto de Arte de Chicago. EUA 


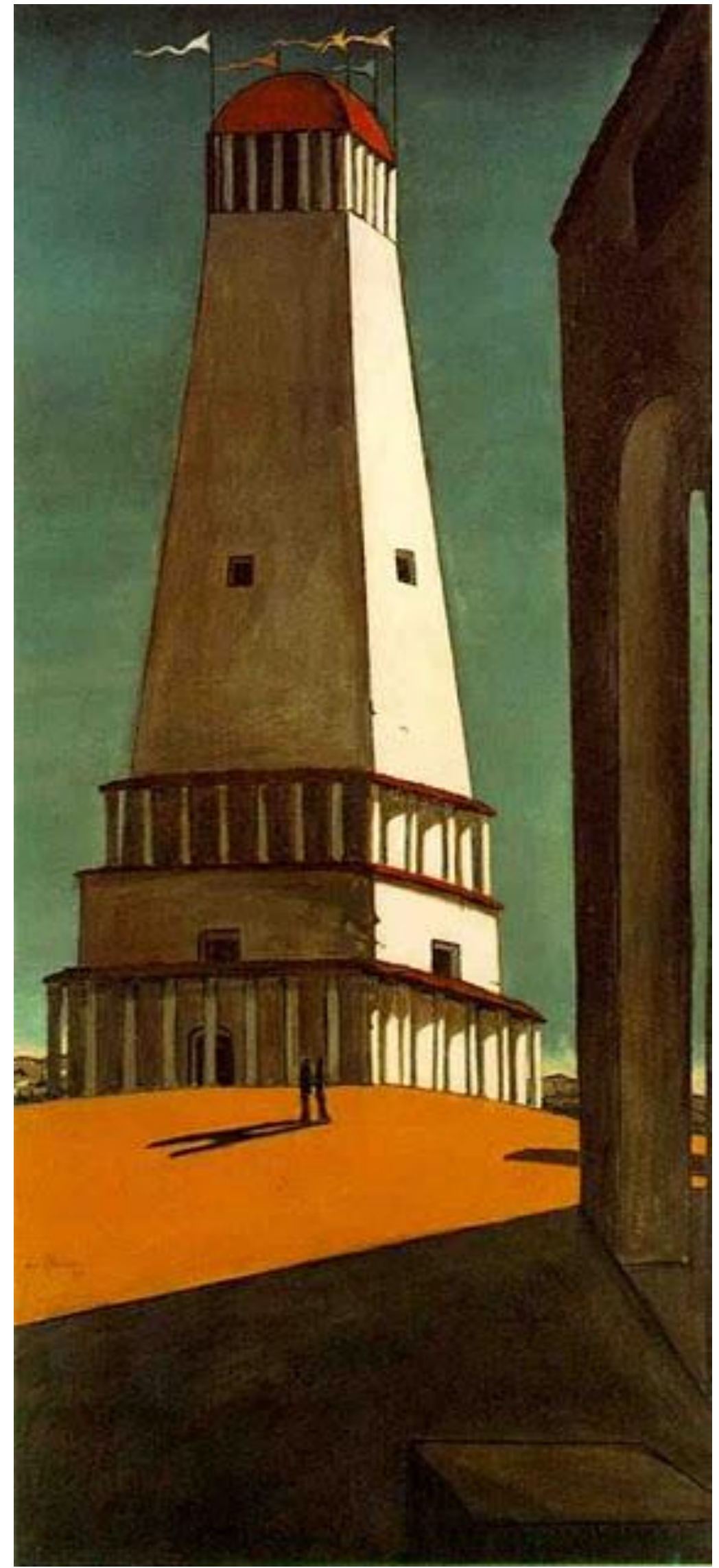

Giorgio De Chirico, A Nostalgia do Infinito, óleo sobre tela, (135,5 x 64,8 cm), 1912 The Museum of Modern Art, Nova York (EUA) 


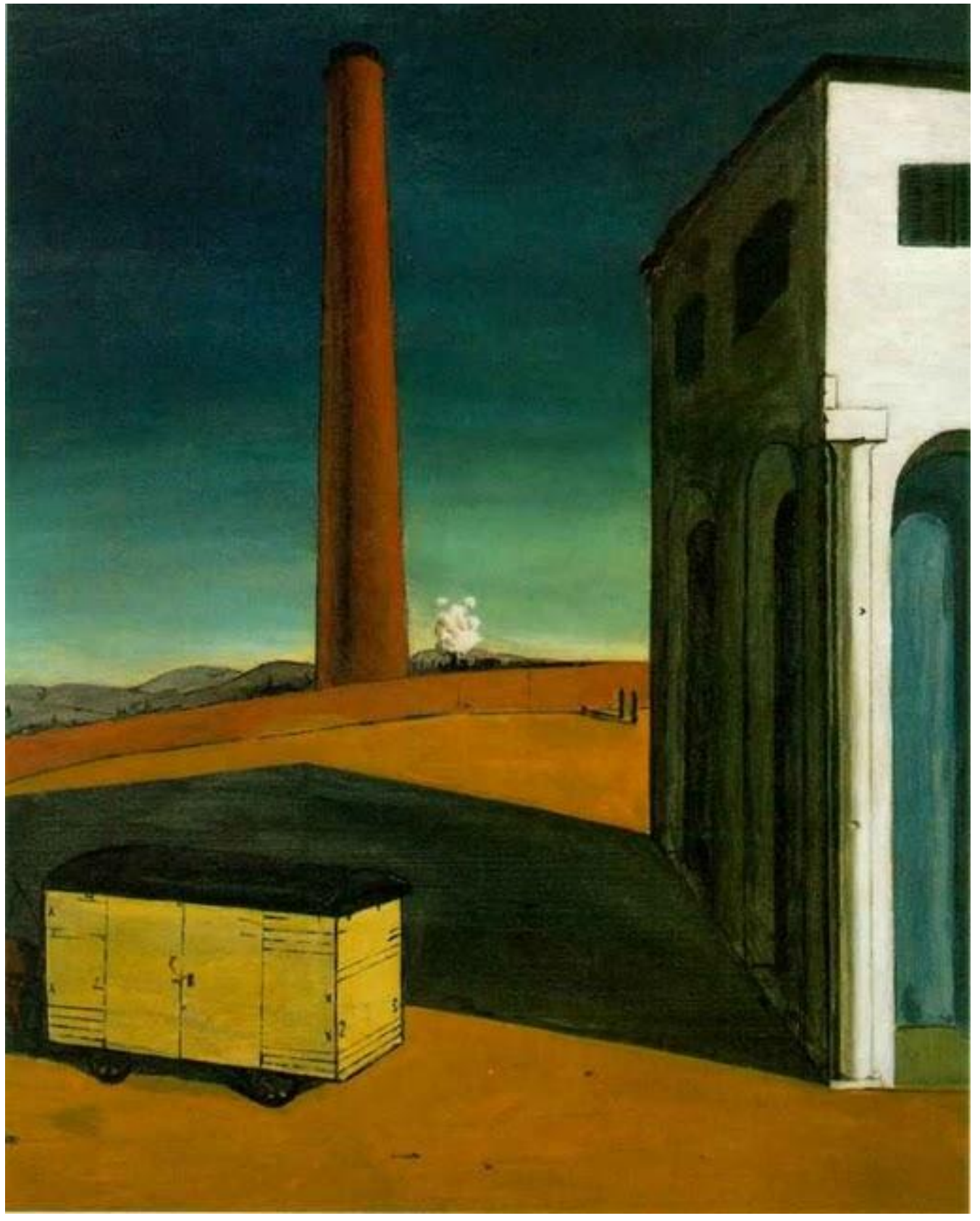

Giorgio De Chirico, A Agonia da Partida, óleo sobre tela, (84,5 x $70 \mathrm{~cm}), 1913$. The Albright-Knox Art Gallery, Buffalo. EUA. 


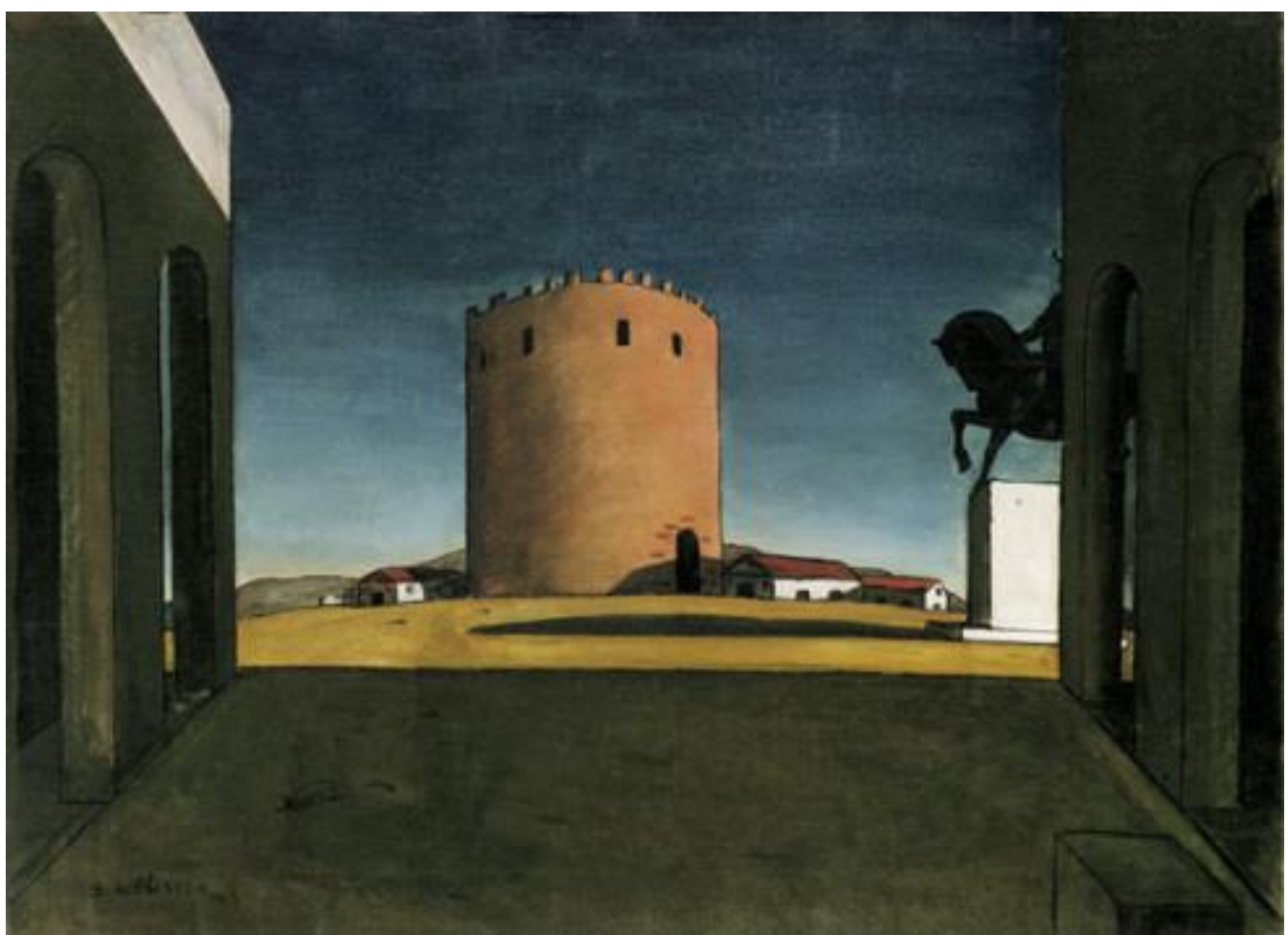

Giorgio De Chirico. A Torre Vermelha, óleo sobre tela, $(73.5$ x $100.5 \mathrm{~cm}) .1913$

The Solomon R. Guggenheim Foundation, Peggy Guggenheim Collection, Venice

(C) 2009 Artists Rights Society (ARS), New York/SIAE, Rome 


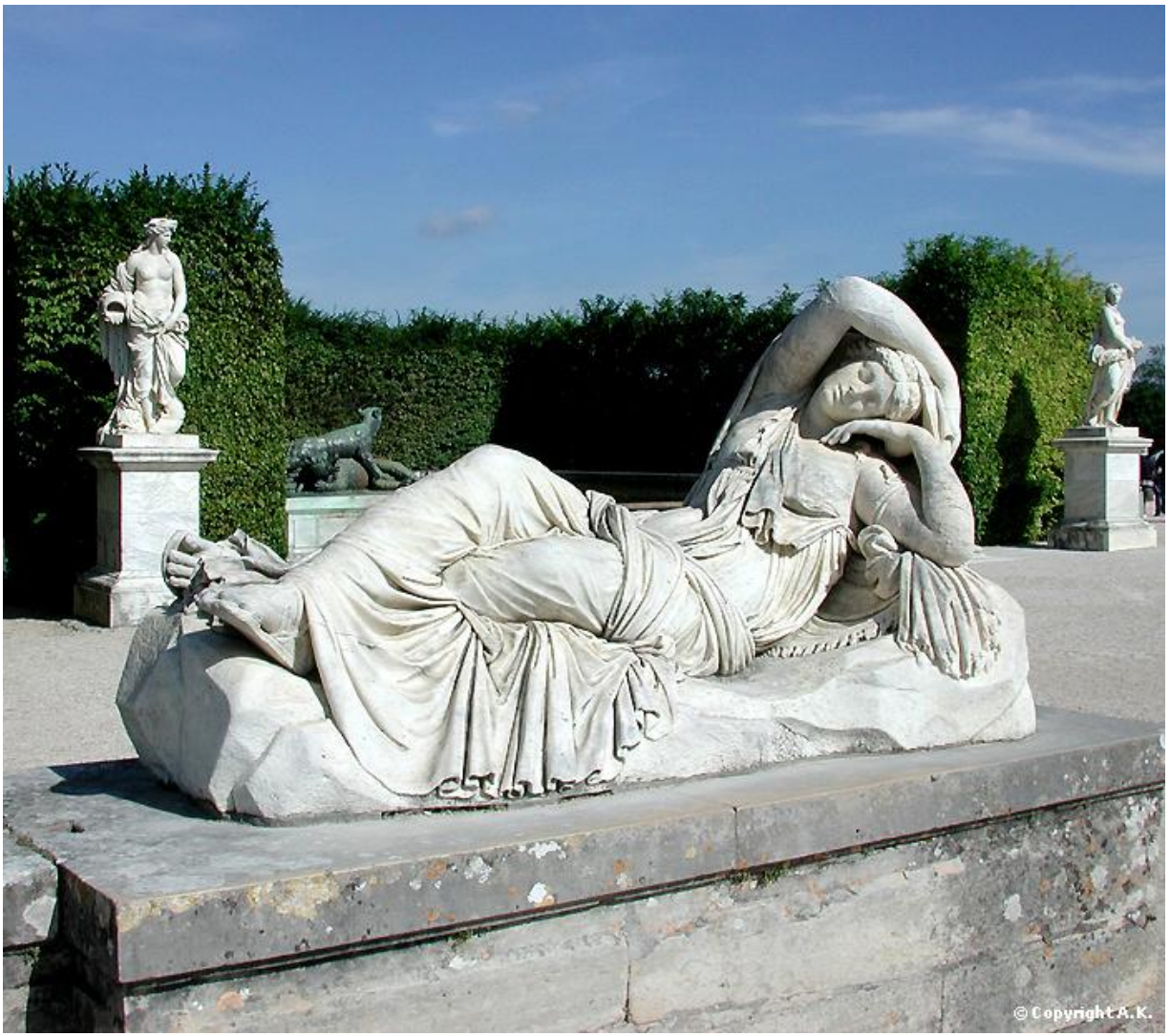

Corneille Van Clève, Ariane endomir, 1688, cópia da estátua grega do Museu do Vaticano, instalação no jardim de Versailles 


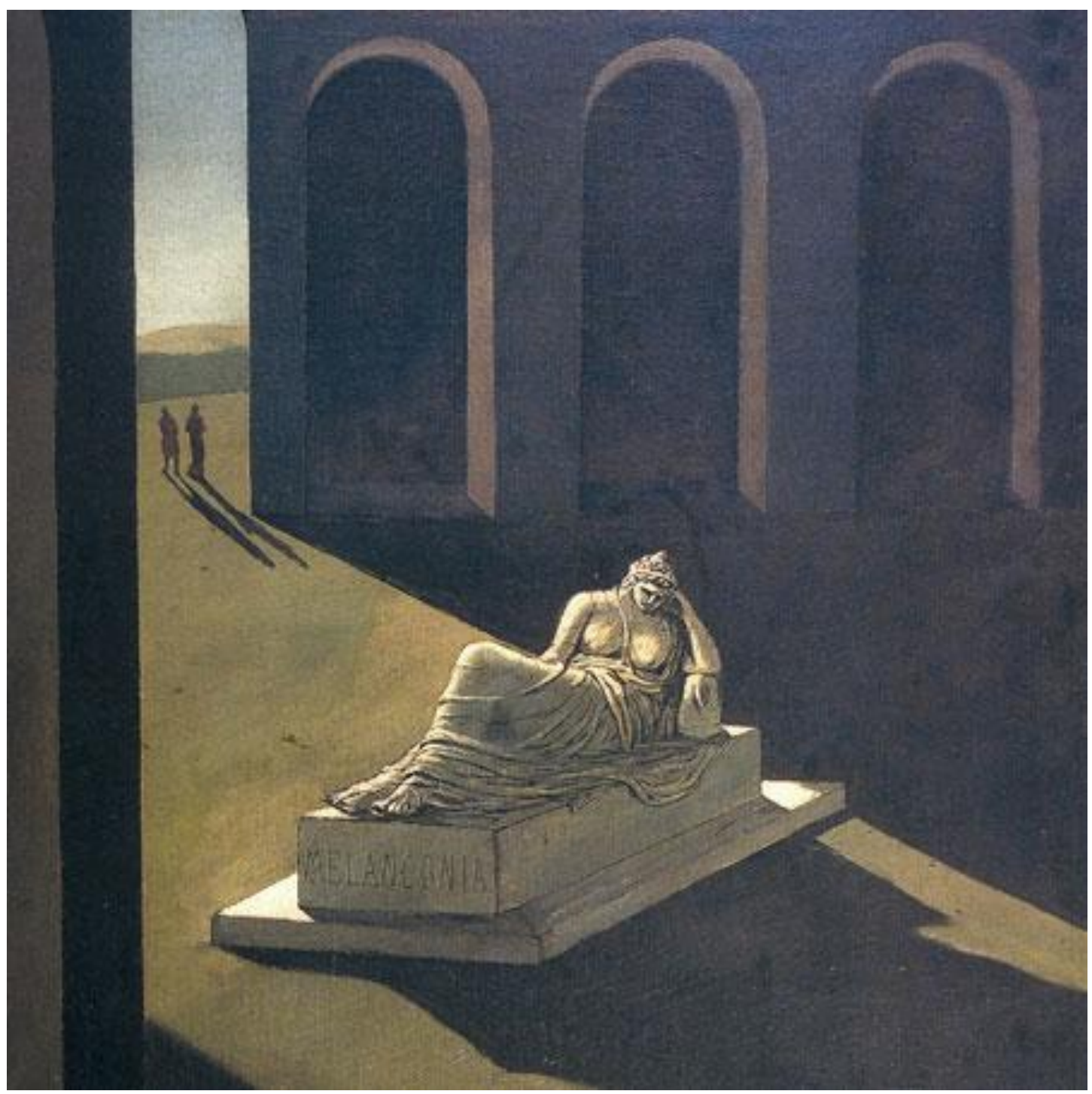

Giorgio De Chirico, Melancolia, óleo sobre tela, (79 x 63,5 cm), 1912. Coleção Particular, Londres (Inglaterra) 


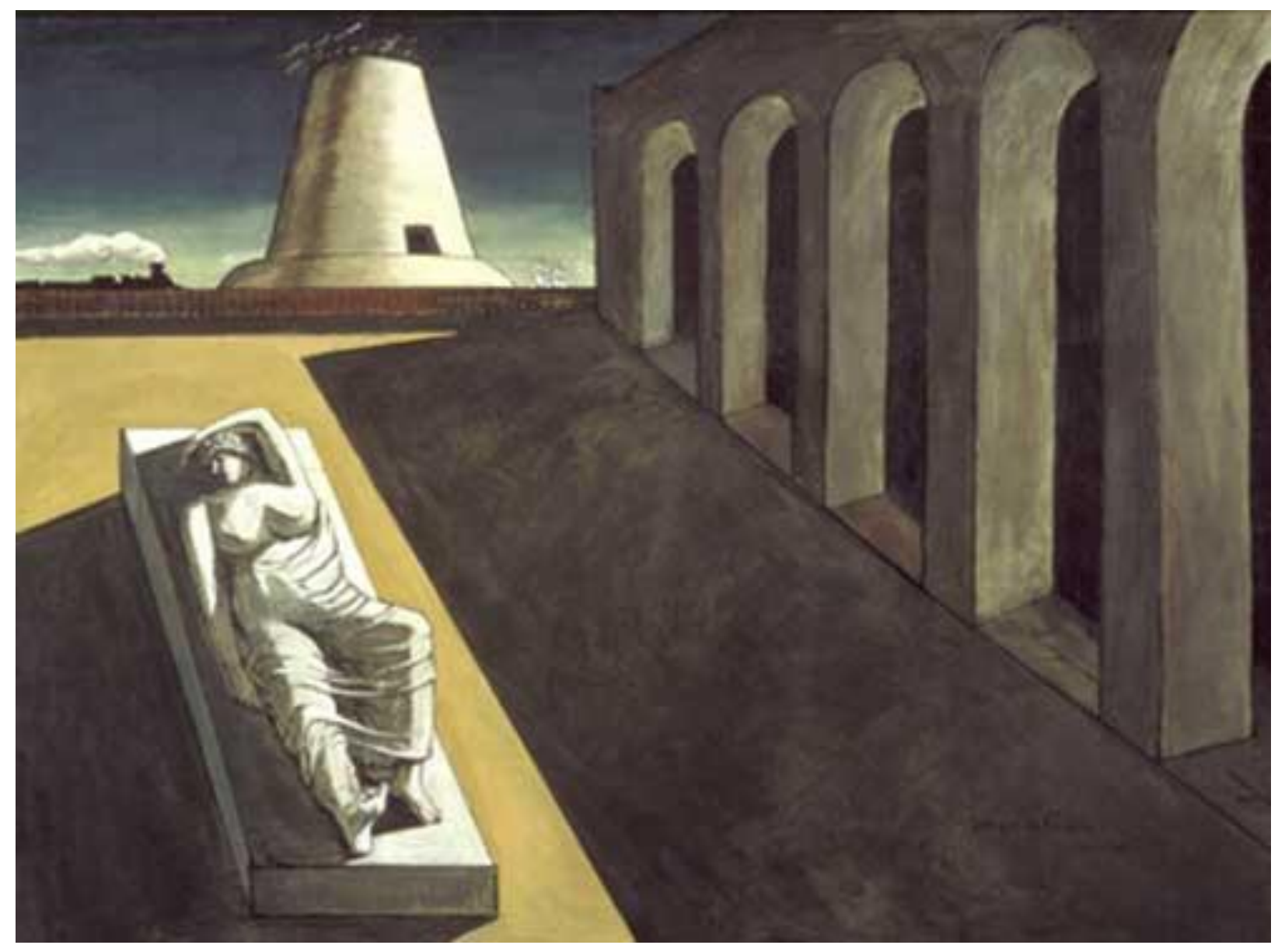

Giorgio De Chirico, Praça com Ariadne, óleo sobre tela, (135,6 x 180,5 cm), 1913. The Metropolitan Museum Art, Nova York. EUA 


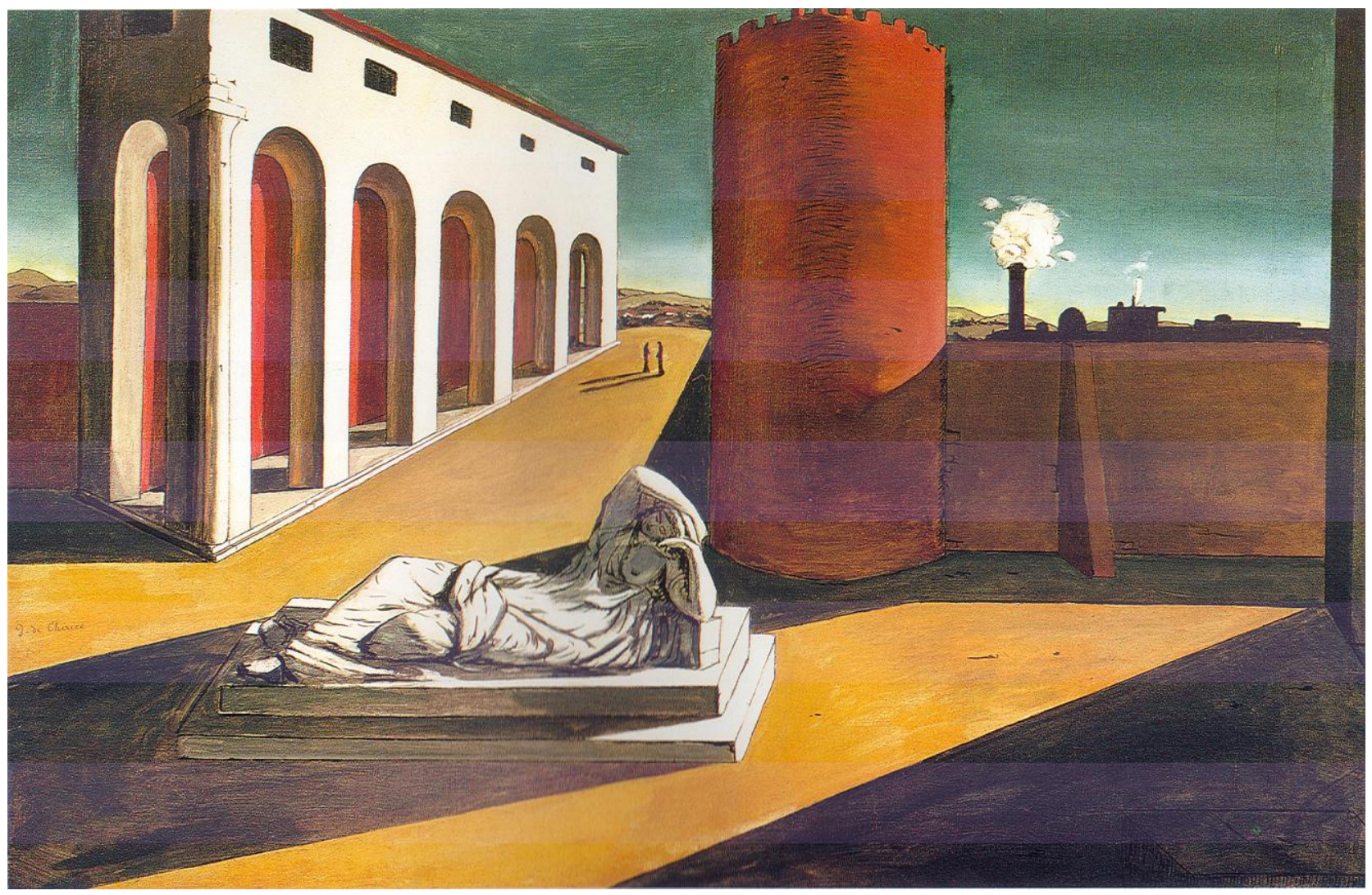

Giorgio De Chirico. As Alegrias e os Enigmas da Estranha Hora, óleo sobre tela, (83,7 x 129,5cm), 1913. Coleção Particular. 


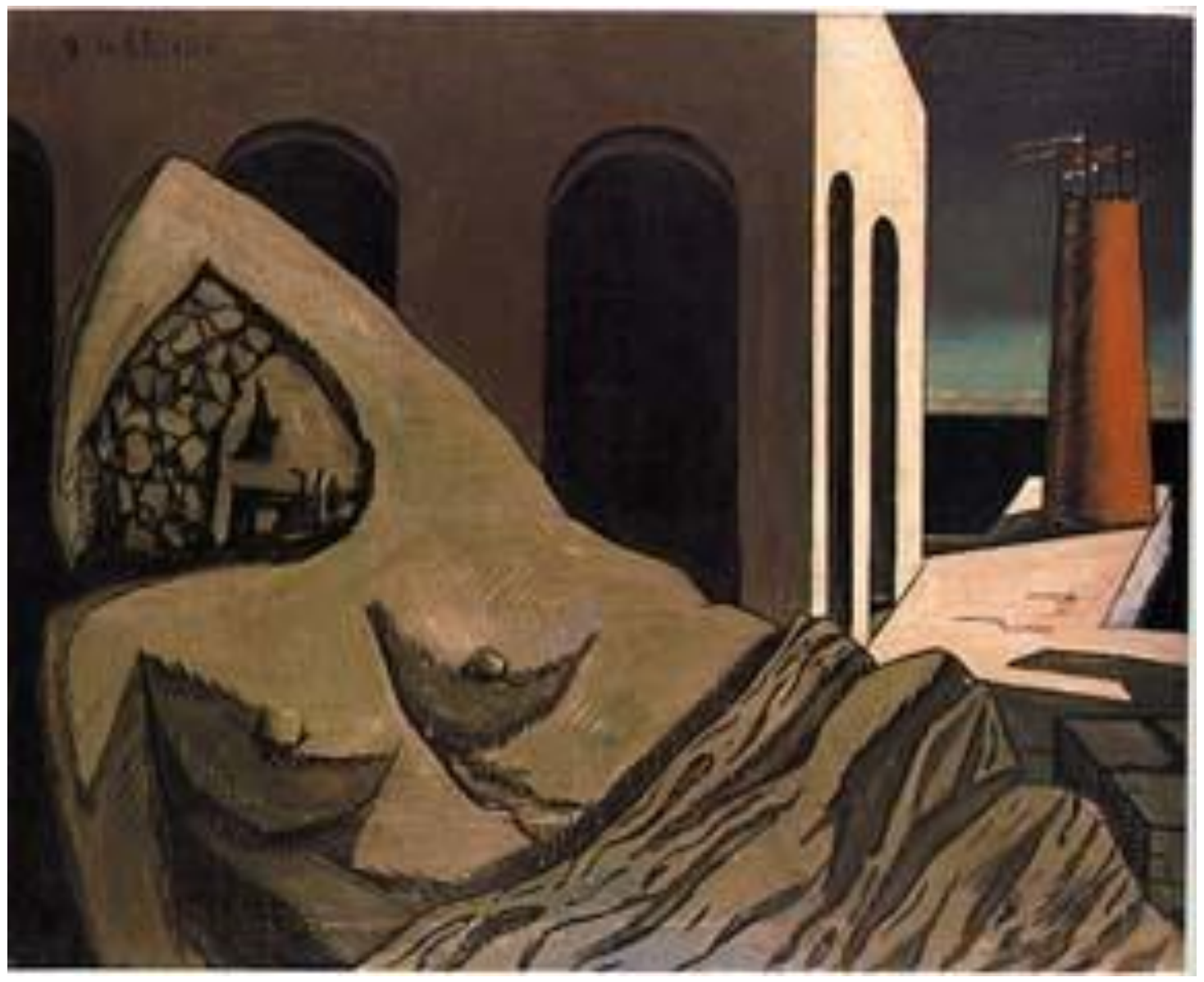

Giorgio De Chirico, O Silêncio da Estátua, óleo sobre tela, 1913 


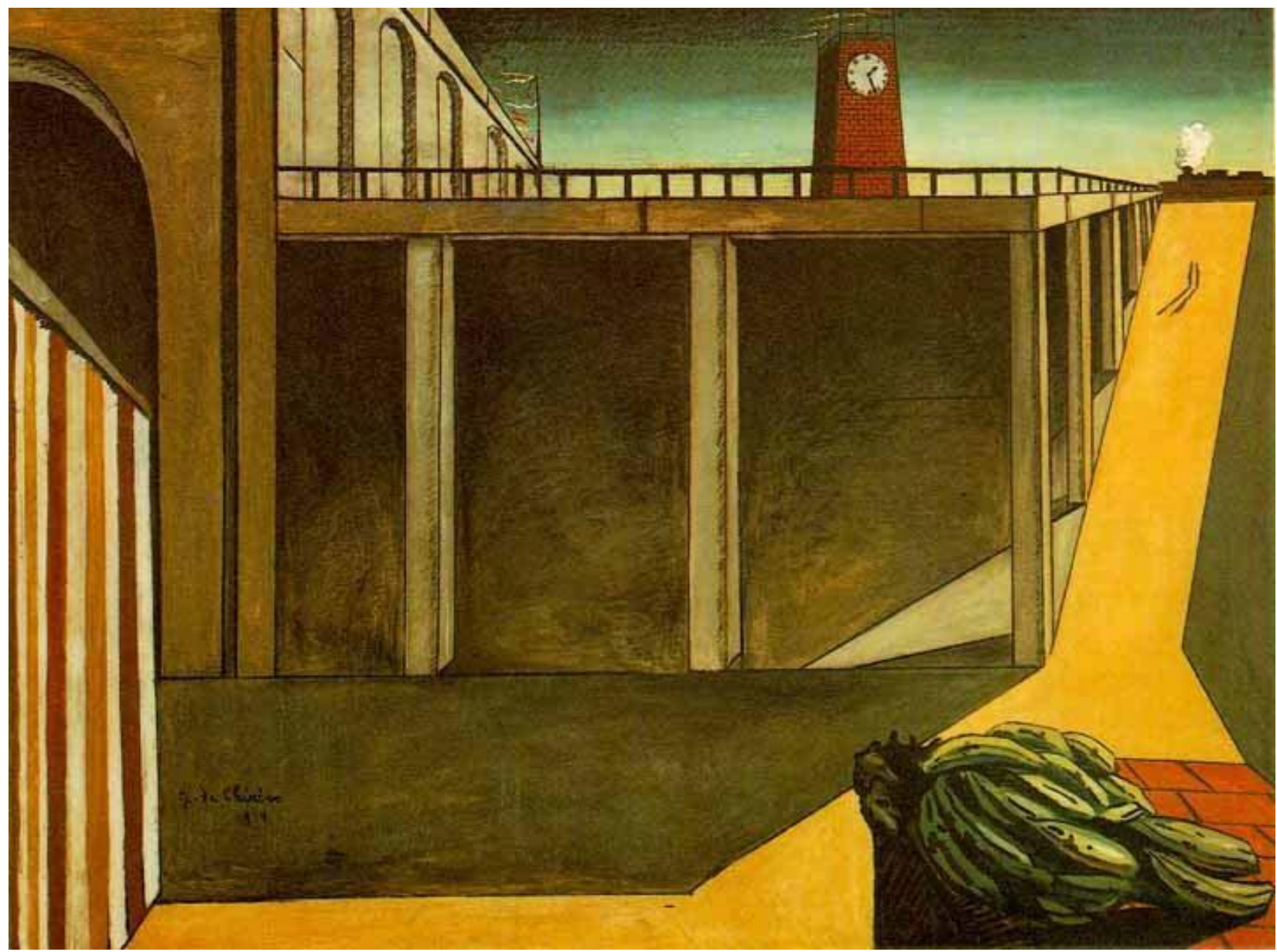

Giorgio De Chirico, Gare Montparnasse, óleo sobre tela (140 x 184,5 cm), 1914.

The Museum of Modern Art, Nova York. EUA

(OBS.: também conhecida como Melancolia da Partida) 


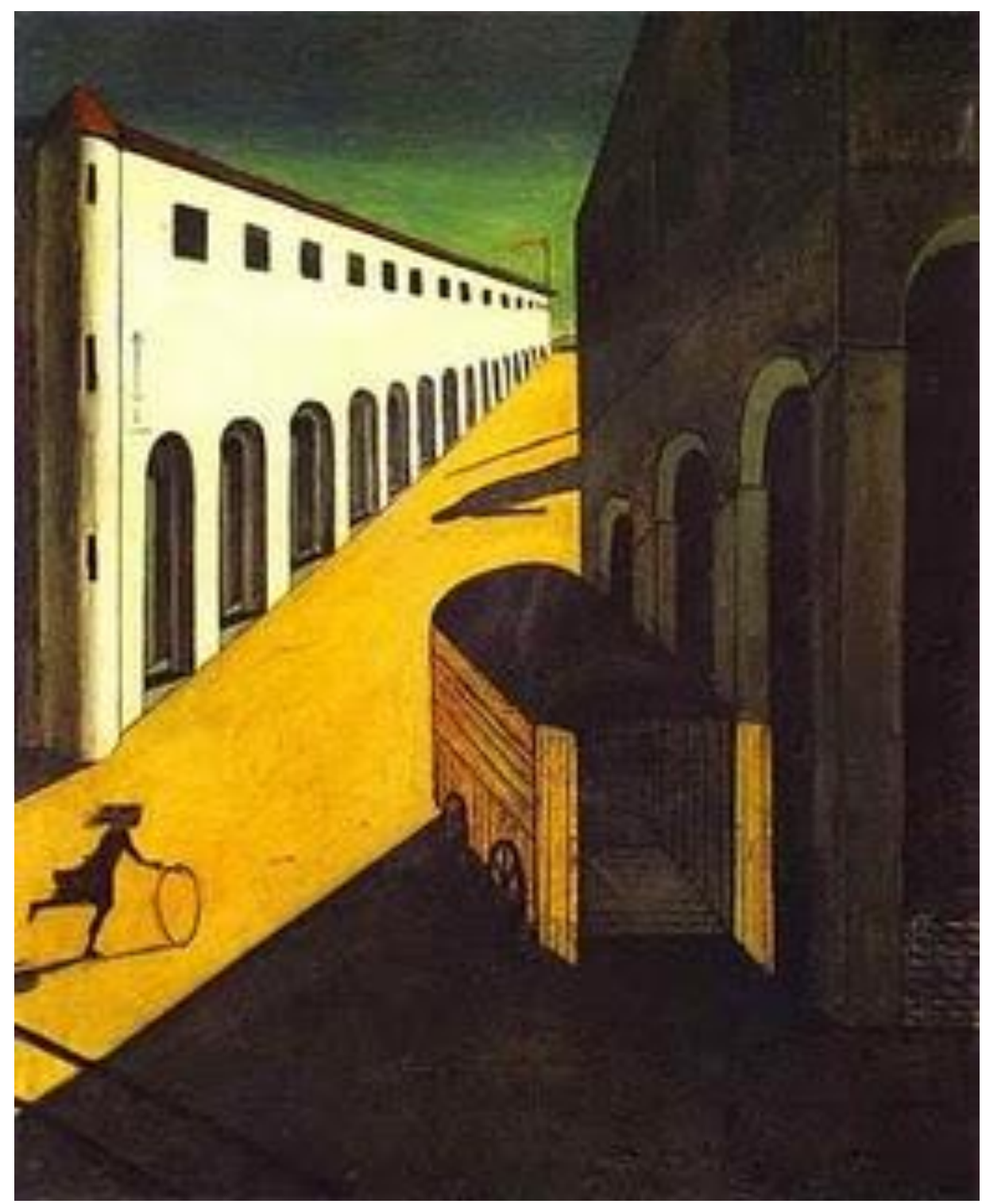

Giorgio De Chirico, Melancolia e Mistério na Rua, óleo sobre tela, (87 x 71,5cm), 1914. Coleção Particular, Nova York. EUA 


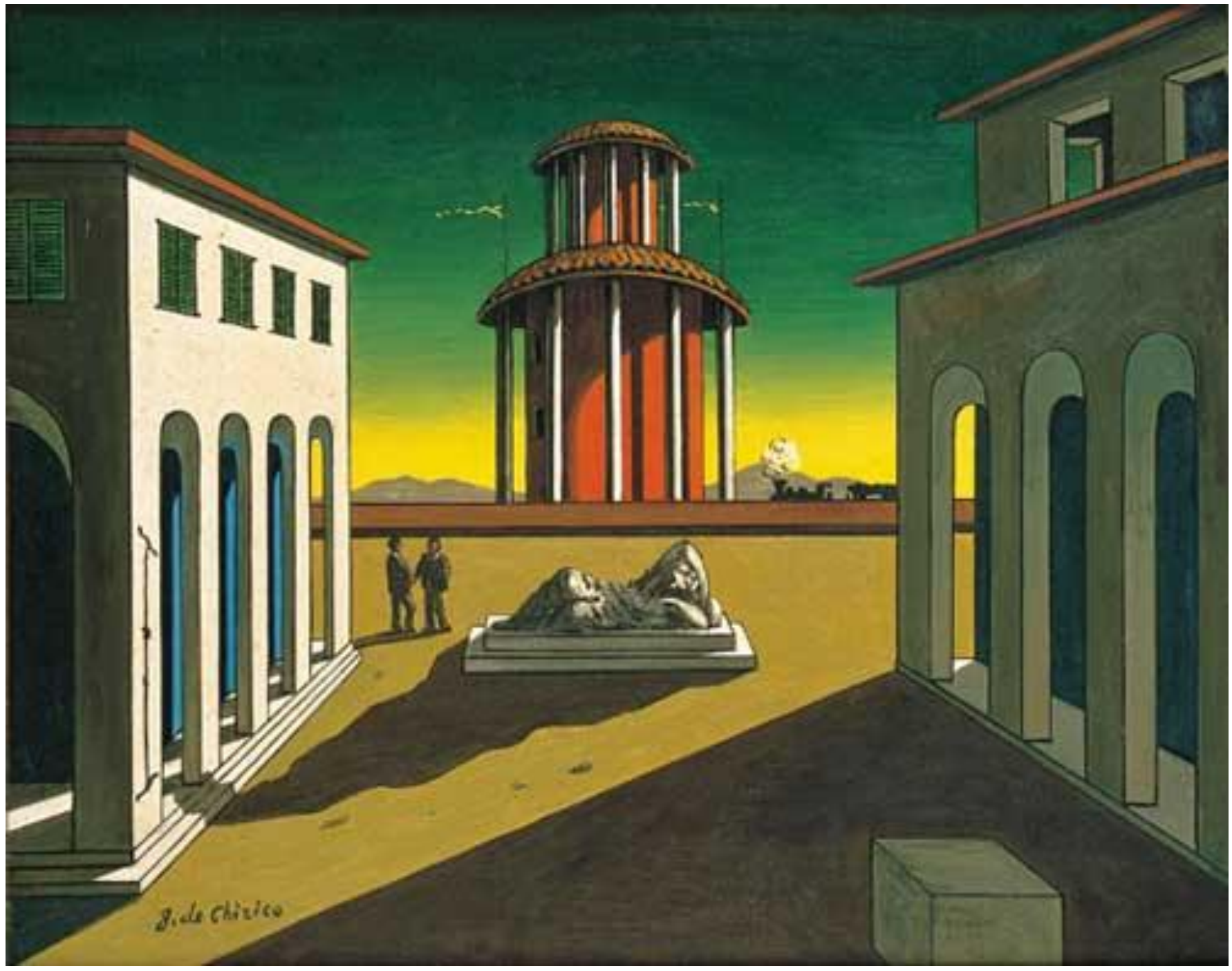

Giorgio De Chirico, Piazza, óleo sobre tela, 1914 


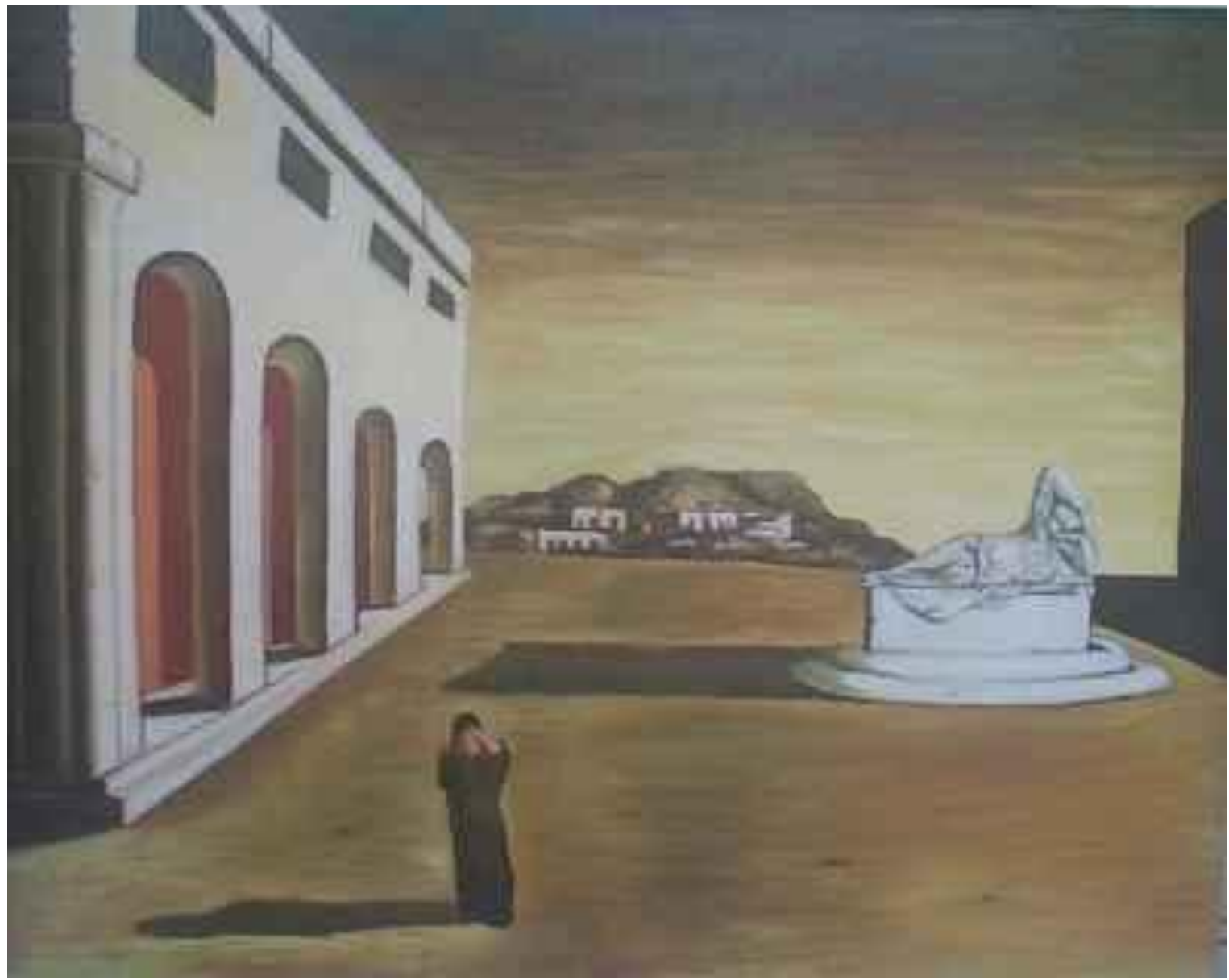

Giorgio De Chirico, Melancolia de um Belo Dia, óleo sobre tela, (89 x 104,5 cm), 1916. Musée des Beaux Arts, Bruxelas. Bélgica 


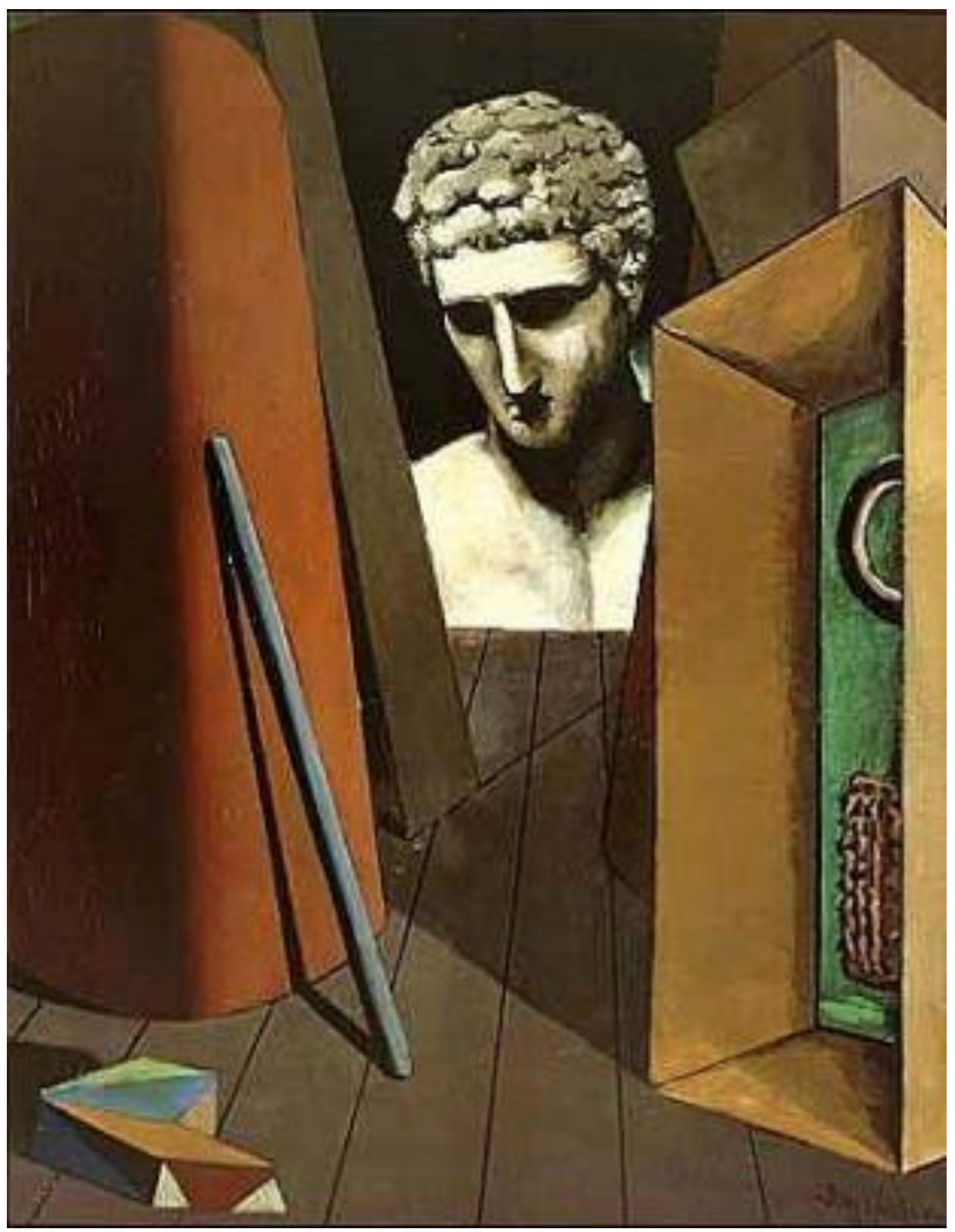

Giorgio De Chirico, Melancolia Hermética, óleo sobre tela $(62$ x $50 \mathrm{~cm}), 1918 / 19$. Museu de Arte Moderna da Cidade de Paris. França 


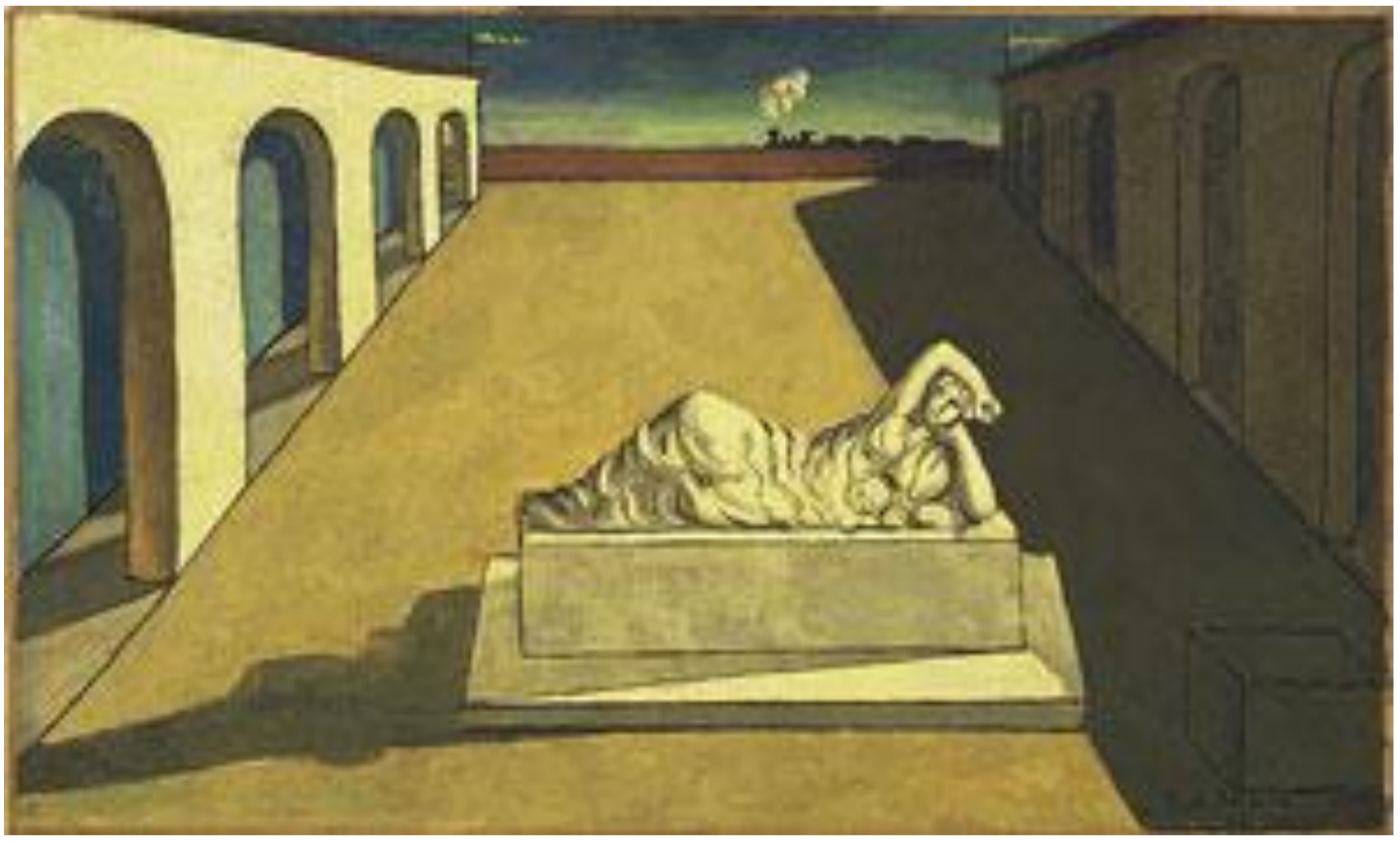

Giorgio De Chirico, La Solitudine, óleo sobre tela, 1920 Allem Memorial Art Museum (EUA) 


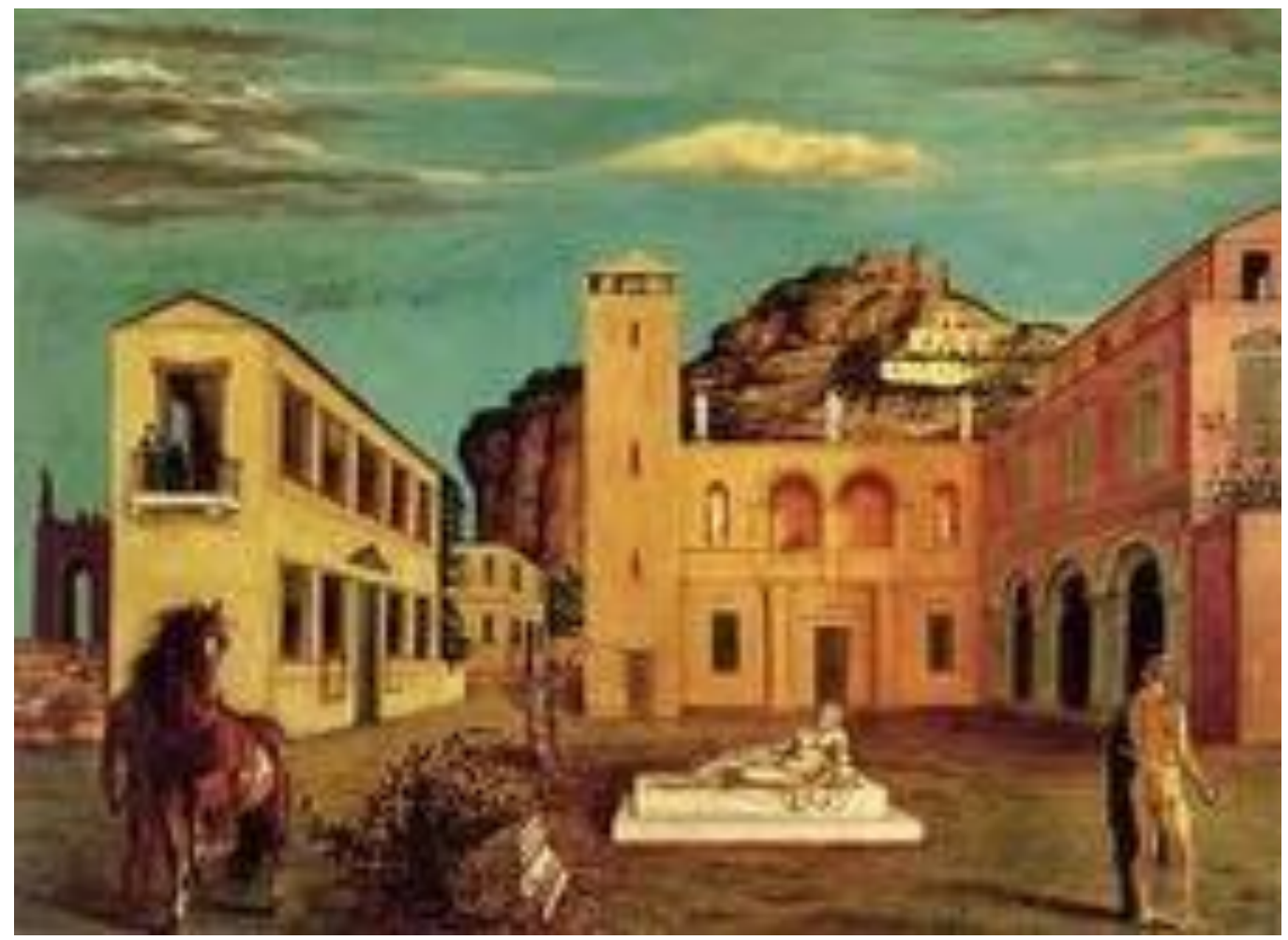

Giorgio De Chirico, Piazza Romana, oleo sobre tela, (76 x 56 cm), 1922. Coleção Particular. Roma. Itália 


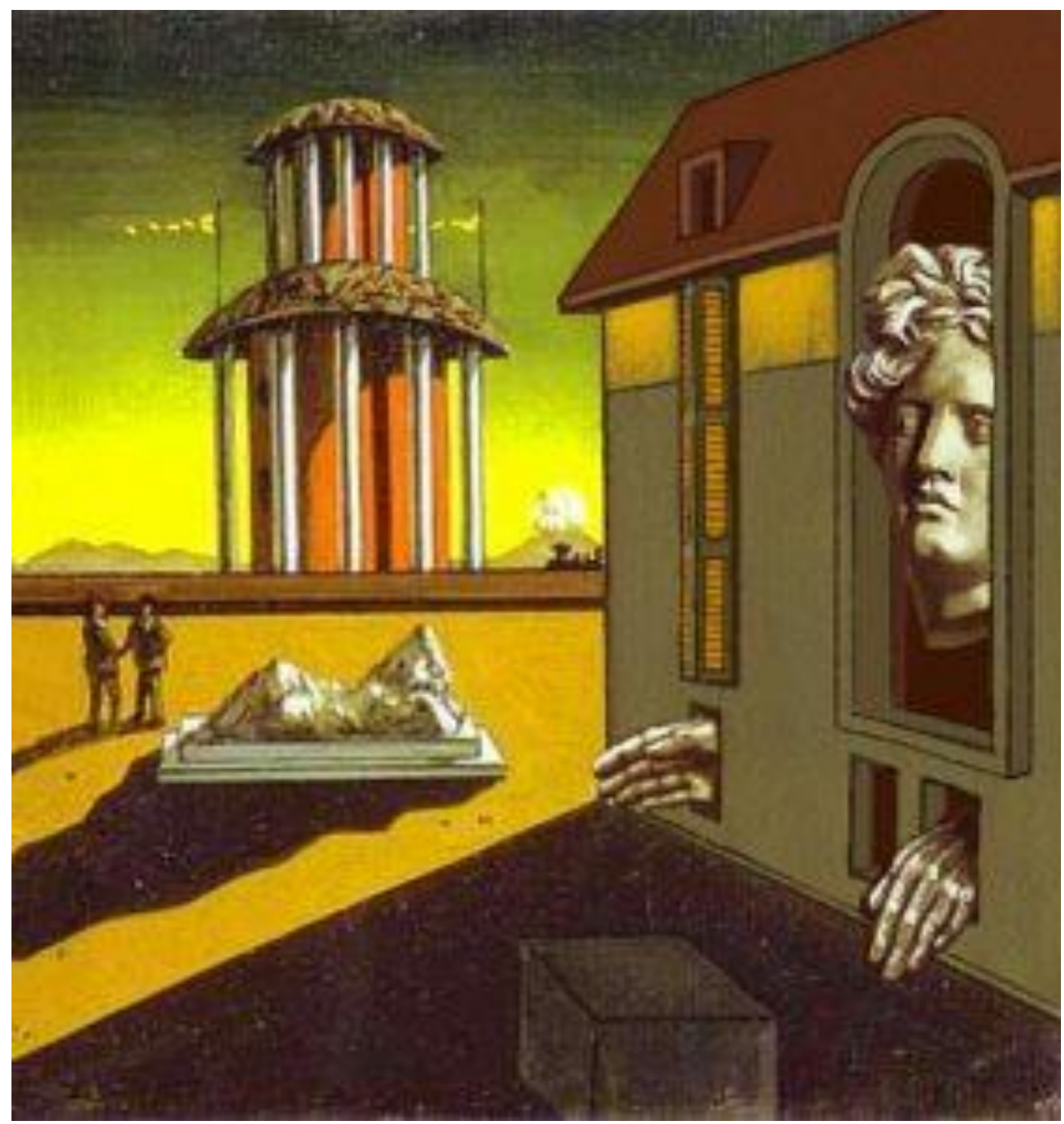

Giorgio De Chirico, Piazza d'Italia,, óleo sobre tela, 1961. Coleção Particular, Londres. Inglaterra. 


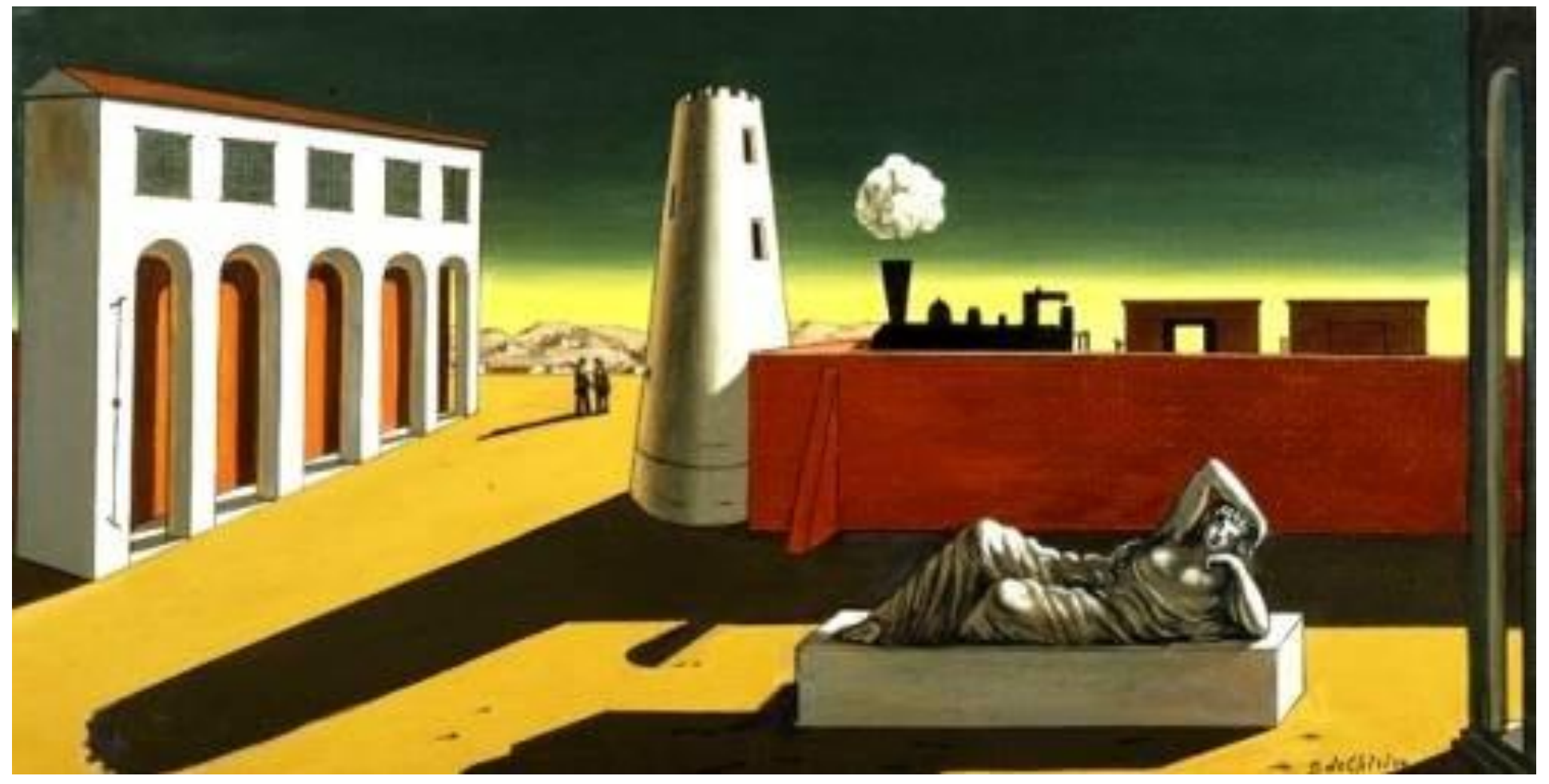

Giorgio De Chirico, Melancolia de Ariadne, óleo sobre tela (48,5 x 92 cm), 1968-71 Galleria Mucciaccia, Roma. Itália 


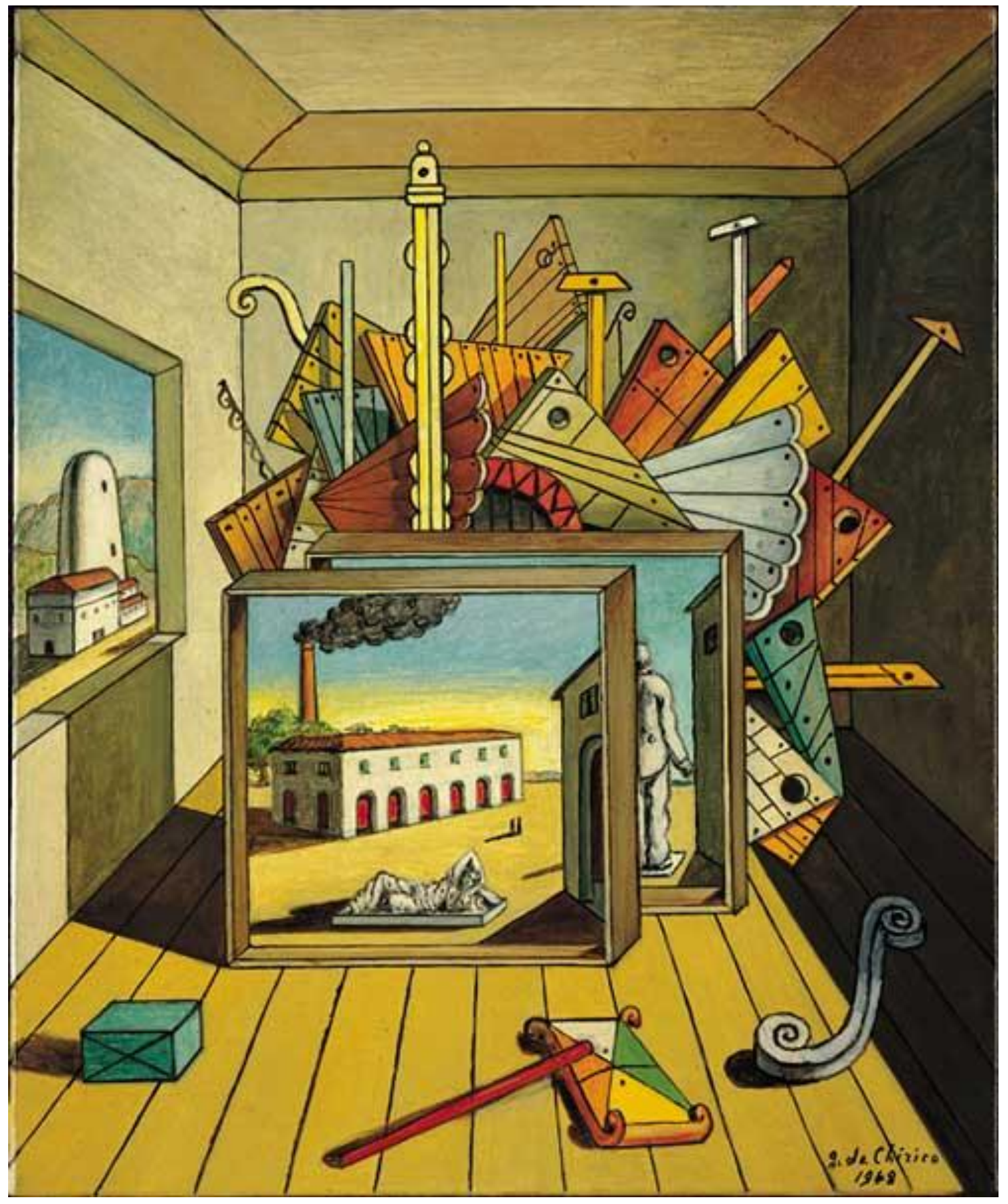

Giorgio De Chirico, Metaphysical Interior with Factory, óleo sobre tela, 1969.

Fondazione Giorgio e Isa de Chirico, Roma. Itália 


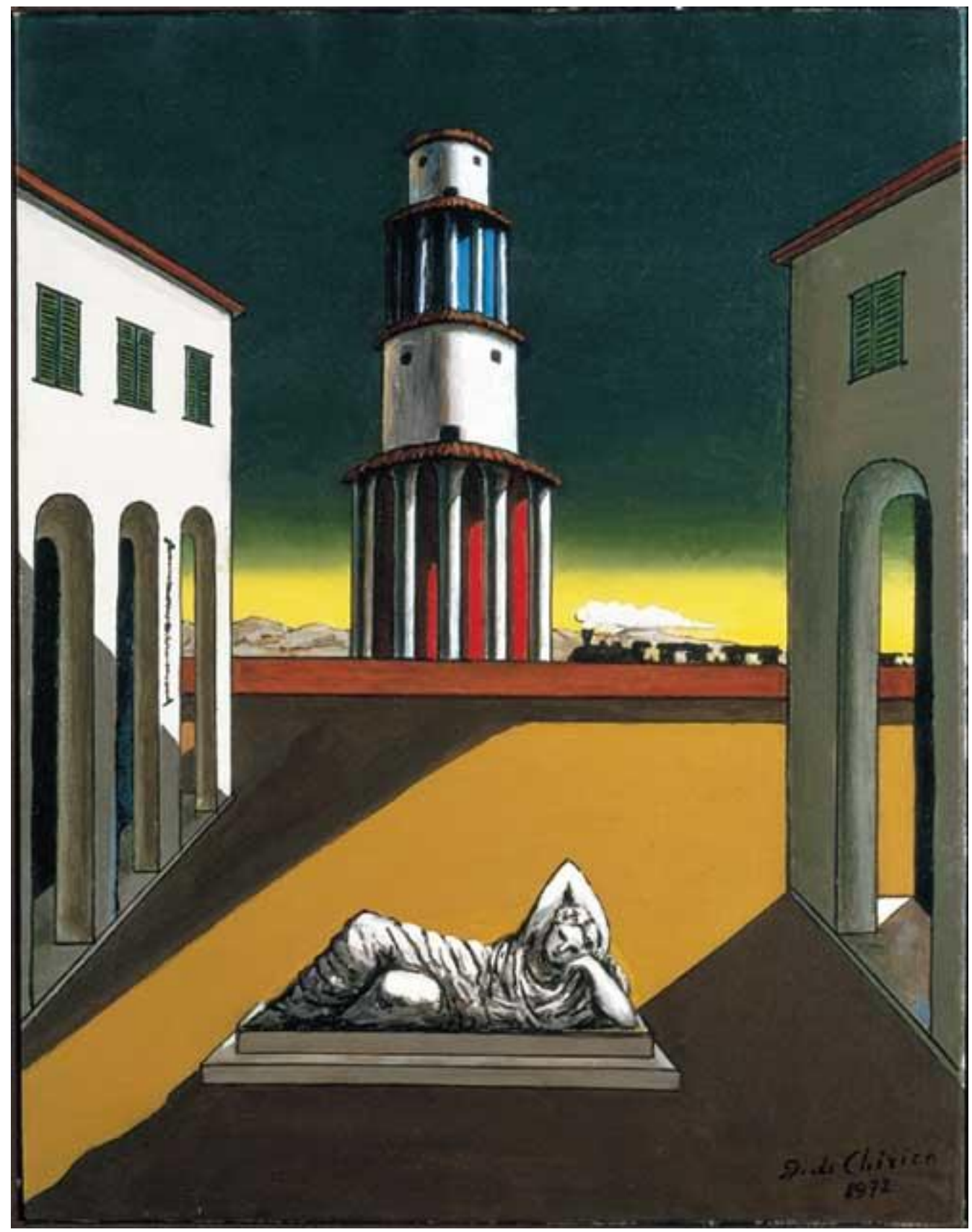

Giorgio De Chirico, Piazza d'Italia, óleo sobre tela, 1972. 


\section{A Atmosfera (Luz e Sombra)}

(...) a tarde de outono chegou, com suas sombras longas, ar claro e céu limpo (...). ${ }^{33}$

Giorgio De Chirico

A retomada da análise sobre a gravura Melancolia I de Dürer e sobre o emprego da perspectiva renascentista na obra de Giorgio De Chirico é pertinente neste momento: a consciência melancólica, segundo Panofsky, de acordo com a tradição, é a consciência do homem que, sob a influência de Saturno, está mais apto às práticas da matemática, particularmente, à geometria e às suas diversas aplicações. ${ }^{34}$ Porém, essa prática confina o espírito num mundo finito da grandeza, da quantidade e do mensurável, faz com que seu praticante suspeite, para além do universo do mensurável. É a descoberta de uma esfera metafísica cuja inacessibilidade o preenche de tristeza. E o pintor, geômetra por excelência na medida em que, para apreender a realidade do mundo fenomenal, é levado a aplicar a ciência exata da perspectiva, sendo o homo melancholicus. ${ }^{35}$

A perspectiva artificial, tal como o Quatrocento, codifica as regras. É este instrumento matemático, cujo uso racional permite apreender o mundo visível e traçar um quadro, que estabelece como equivalente o que está representado e o que é visto. Mas ela é também o artifício que, além de visível, introduz o espectador no discurso sobre a realidade do mundo existente na tela; imagem de um falso infinito, ela cria a ilusão de um espaço pela única combinação de relação de proporções; o desvirtuamento desta ilusão introduz o espectador à ausência de ser e à falta de sentido. Se esta perspectiva fixa e

\footnotetext{
${ }^{33}$ DE CHIRICO, Giorgio. APUD. BALDACCI, Paolo. The Function of Nietzsche's thought in de Chirico's art in: Nietzsche and na Architecture o four minds. Editado por Alexandre Kotska e Irving Wohl Farth Los Angeles; Getty Research Institute for the History of Art and the Humanities, 1999, p. 93.

${ }^{34}$ PANOFSKY, Erwin. Saturn and Melancholy ... op. cit.

${ }^{35}$ CLAIR, Jean. "Maquinismo e Melancolia". In: GALERIES NATIONALES DU GRAND PALAIS, Mélancolie: Genie et Folie en Occident...op.cit., p. 440 e seguintes.
} 
centrada instala o espectador no lugar do rei, trata-se de um rei despojado de seu reino. $^{36}$

As primeiras telas de Giorgio De Chirico a usar o título Melancolia são também as primeiras, a testemunhar uma preocupação sobre a perspectiva evidente e, mais especificamente, as primeiras em seu repertório a aprofundar o efeito dessa perspectiva, a excedê-lo até torná-lo irreal. ${ }^{37}$ Toda a ambiguidade do movimento de restauração clássica que se elabora na obra de Giorgio De Chirico e de seus sucessores converge, com efeito, no emprego que faz do dispositivo da perspectiva dos renascentistas: esses artistas o reutilizam, eles o reinventam, eles redescobrem sua estranha sedução, mas é para evidenciar sua disfunção fundamental, para manifestar aquilo que nele é apenas latente: não mais seu poder de evidência, mas sua carga de enigma. ${ }^{38}$

De Chirico, desse modo, tornar-se o mestre destas falsas perspectivas, nas quais se cruzam pontos de vista incompatíveis, resultando em combinações de perspectivas aceleradas e de perspectivas tranquilas, instalando, finalmente, no cubo cênico, uma cenografia que não é mais a de um espaço comum, habitável e familiar, mas a de um teatro de sombras semeado de armadilhas e de falsas janelas. A perspectiva renascentista é um instrumento de racionalização do invisível. É a esperança que o homem poderia ter tido sobre si mesmo e que ele pode, pela matemática, tornar-se mestre e dono da natureza. Somente o humanismo de um Dürer teria pressentido o caráter profundamente melancólico de tal empreitada que consiste, no final das contas, em deixar o indivíduo preso pela sombra das aparências.

O sentido da melancolia que De Chirico propõe é diverso: é uma melancolia "moderna". Quando o artista pesquisa "os signos herméticos de uma nova melancolia", inverte de alguma maneira as etapas do processo representativo. ${ }^{39}$ Ele não parte mais do corpo visível e material, como outrora

\footnotetext{
${ }^{36}$ Idem.

${ }^{37}$ Idem.

${ }^{38}$ Idem.

${ }^{39}$ Idem.
} 
Uccello ou Masaccio para, por fim, traçar os delineamentos em duas dimensões da tela. O método das sombras ${ }^{40}$ que, na perspectiva clássica, permite confirmar a realidade do corpo material que é sua fonte, é afastado de tal modo que é a sombra, doravante, tornada aparição, entidade espectral, fantasma. A sombra se torna o signo da ausência de realidade - levada, por vezes, ao absurdo quando sobre a tela desenha-se isolada a sombra inquietante de um corpo inexistente. Não se utiliza mais, então, a coerência a priori de um sistema lógico de coordenadas para confirmar a coerência do mundo exterior; ao contrário, fazendo uso do dispositivo da perspectiva, o artista desata, realmente, os laços que as coisas parecem possuir entre elas.

Recorda-se que no século XVIII, a sombra surge como a valorização dos aspectos sinistros da materialidade dos objetos, reverberando em sua representação a naturalidade da imagem visual convertida em realidade. Já no pós-romantismo, a sombra abandona sua função narrativa para se tornar pesquisa plástica - ela é utilizada como artifício para a expressão dos sentimentos, ou seja, como algo capaz de transmitir a atmosfera moral da imagem retratada. $\mathrm{Na}$ produção de Giorgio De Chirico, particularmente a realizada entre os anos de 1914 e 1918, as sombras assumem o papel relevante de recurso pictórico. Em 1913, o artista declara: "há mais enigmas na sombra de um homem que caminha ao sol do que em todas as religiões passadas, presentes e futuras". "A A afirmação provocativa plasma-se às suas telas que mostram espaços urbanos irreais, povoados somente por estátuas, pórticos, chaminés, torres e sombras - um ambiente estranho, moldado por perspectivas irreais, cercado de silêncio e solidão.

Quando essas perspectivas de pedras, colunas, pórticos, arcadas, ampliam-se ou reduzem-se, como se ampliam ou se reduzam as sombras é, com

\footnotetext{
${ }^{40} \mathrm{Na}$ arte ocidental, a sombra tem seu emprego relacionado à intenção naturalista. Uma fábula antiga de Plínio, o Velho, coloca a origem do uso da sombra em Corinto, onde uma jovem, filha do ceramista Butades de Sicyon, traça a imagem de seu amante em uma parede com o auxílio da luz de uma vela. STOICHITA, Victor I. La Sombra. Madrid: Museo Thyssen-Bornemisza, 2009 , p. 14 e seguintes.

41 APUD. MICHALSKI, Sergiusz. "Sombras de soledad, sombras de amenaza". IN: STOICHITA, Victor I. La Sombra. Madrid: Museo Thyssen-Bornemisza, 2009, p. 52.
} 
efeito, porque elas deixam de ser a representação das paredes sólidas e reais para tornarem-se a representação de sombras dentre as sombras. Luz e sombra são elementos inseparáveis que expressam as formas e os volumes em "tinta da melancolia" - um espaço de expressão pictórica da perspectiva e do volume. As sombras podem construir efeitos de ótica puramente espacial. Na pintura moderna, a sombra é frequentemente utilizada para modelar os volumes, contudo, De Chirico usa as sombras projetadas de forma livre - sem o compromisso volumétrico.

Na tela Melancolia e Mistério na Rua (1914), por exemplo, a sombra projetada, bastante ameaçadora, reproduz a forma que se ergue - invisível para o espectador. A menina que corre com um aro projeta uma sombra minúscula, recortada pela sombra da arquitetura circundante que se torna uma figura tenebrosa - a sombra emprega-se como quase abstrata. De Chirico, expressamente, dá subsídios para uma concepção da solidão por intermédio das sombras.

Suas sombras renunciam definitivamente toda a intenção naturalista que possa existir na forma: sua função é projetar sobre o solo um "conflito de sombras" imaginário, confronto que por sua vez cria a complexidade do mundo natural. Nos manequins, datados de 1916 e 1918, as sombras se fazem mais estreitas e alargadas, à medida que revelam a natureza artificial dos manequins. De Chirico pensa na solidão dos elementos pictóricos, concebendo as linhas, os ângulos, os volumes, a luz e a sombra, como mistérios revelados pelo pintor e que, portanto, adquirem voz e, também por isso, um aspecto enigmático.

Em De Chirico, a sombra dá à cena um ar de pesadelo - de imagem proveniente de devaneios e delírios. A dramaticidade dos ambientes é, em grande parte, atribuída à luz crepuscular e às sombras projetadas. A luz crepuscular é a mesma da "revelação" da Piazza Santa Croce, ao passo que, as sombras fornecem a realidade enfraquecida dos objetos presentes ou não na cena retratada. $O$ espectador é envolvido pelo mistério do cenário teatral - desprovido de personagens e ação. Mundo inerte, povoado por "signos solitários", onde a 
atmosfera remete à contemplação e à meditação, por extensão, à melancolia. Essa antinomia é típica dos pintores metafísicos, nos quais é sinistro viver com a falsa aparência de uma ordem - daí a herança do tratamento meticuloso da sombra atribuída aos surrealistas.

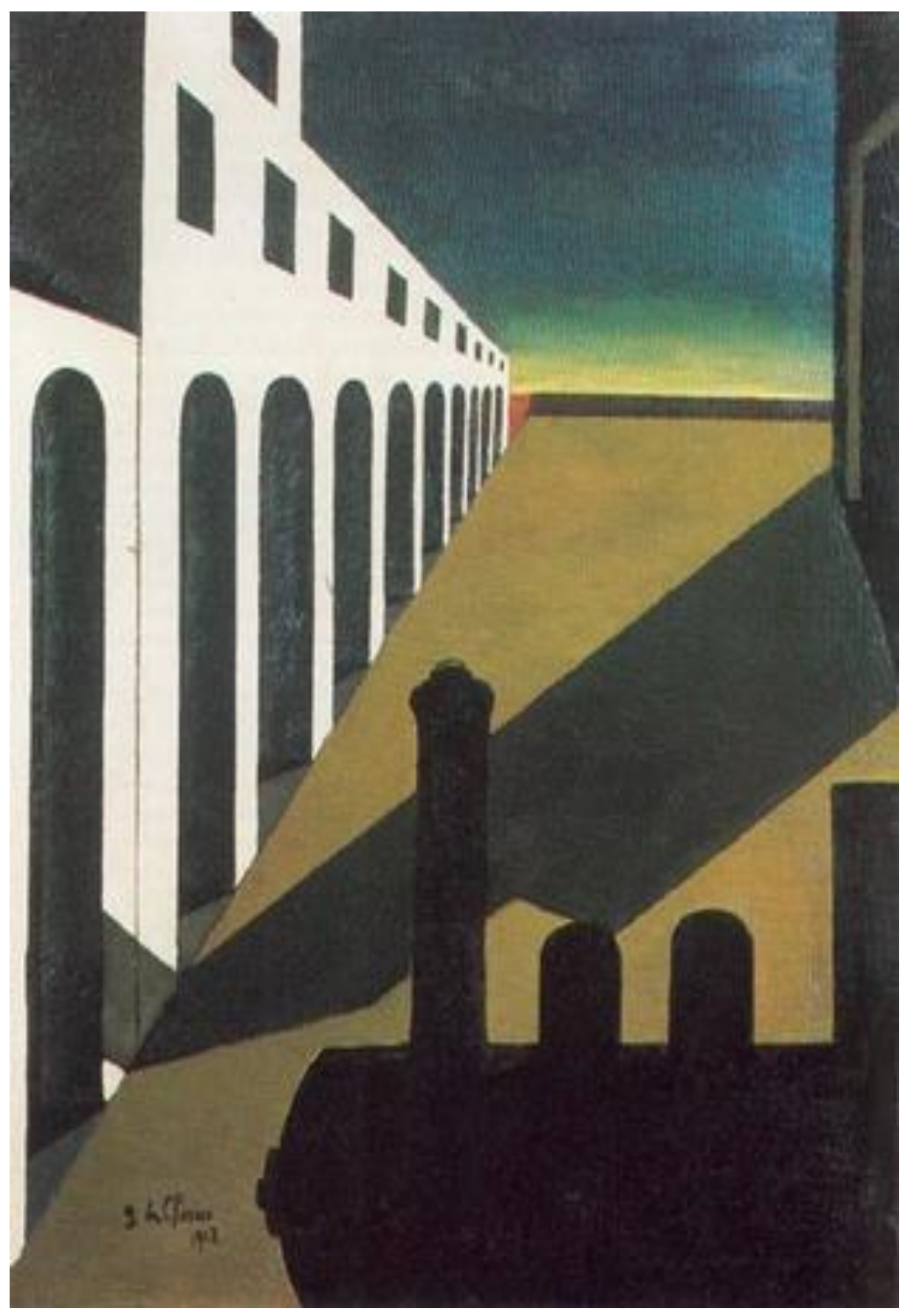

Giorgio De Chirico, Manhã Angustiante, óleo sobre tela, (80, 5 x 65 cm), 1912. Museum Ludwig, Colônia. Alemanha. 
CONSIDERAÇÕES FINAIS 
(...) Somos, para nós mesmos e para os outros, enigmas. (...) A melancolia é o sofrimento desse mistério. ${ }^{1}$

Jackie Pigeaud

Onde se encontram as questões estéticas da melancolia? No medo perante a morte ou na contemplação frente ao enigma da vida? Que semelhança há entre o olhar que vê a morte e o olhar perdido da figura feminina representada por Albert Dürer? A melancolia não é o sinônimo de morte nem de loucura. Ela é uma das expressões da vida diante da morte. É o olhar que está fora da temporalidade, que olha o vazio das coisas, pasmado diante do mistério da existência. Mistério este manifesto no incompreensível da passagem de um estado para o outro, isto é, da vida para a inevitável morte. As questões estéticas sobre essa passagem registram-se ao longo da História da Arte, legitimando uma tradição do sentimento melancólico.

A "doença" da relação entre a alma e o corpo, historicamente, passa por diversos discursos: o médico, o filosófico, o científico, o político, o religioso e o artístico. Aristóteles transforma a melancolia em natureza do ser (temperamento); a Idade Média converte-a em pecado capital (acedia); o Renascimento ratifica o caráter excepcional do gênio melancólico; já o Iluminismo desvaloriza tal sentimento, visto como fraqueza do indivíduo; o Romantismo renova os votos de genialidade dos que sofrem de atrabilis e Giorgio De Chirico constrói sua poética a partir dessa extensa tradição.

De Chirico é um melancólico tal como Watteau? Sim e não. De Chirico descreve, em muitas passagens de sua vida, um temperamento melancólico. Relata, em seus escritos, as crises que podem ser consideradas subsídios para o

\footnotetext{
${ }^{1}$ PIGEAU, Jackie. Metáfora e Melancolia: Ensaios Médico-filosóficos. Rio de Janeiro: Contraponto/PUC Rio, 2009, p. 199.
} 
diagnóstico doentio. No entanto, neste estudo, não se tem a preocupação de provar sua patologia clínica. O que realmente importa são os fatos que indicam que o pintor assume a tradição melancólica vinda de sua origem e erudição. Sua projeção pessoal baseia-se no Problema XXX de Aristóteles e os fatores determinantes de suas composições orientam-se pelo víeis melancólico vindo da leitura peripatética, passando pelo Renascimento e adentrando ao Romantismo. A “doce melancolia" de Watteau e Vien que valoriza o prazer da meditação, acrescida pelas leituras românticas, configura-se, na obra de De Chirico, em algo que estimula o espectador à reflexão.

A vertente romântica de Böcklin e Klinger, a filosofia existencialista de Nietzsche e Shopenhauer, o temperamento do artista, seu estado de saúde, os constantes deslocamentos territoriais (Volos, Monique, Turim, Florença, Ferrara, Paris, e outros lugares), seu contexto (a inesperada perda do pai, o período entreguerras e o sentimento de identidade nacional) e seu repertório (os "signos solitários", o emprego da perspectiva, a dimensão arquitetônica, a luz crepuscular e a sombra) compõem a atmosfera melancólica na obra de Giorgio De Chirico. Engendrado por um vocabulário metafórico, tal sentimento é vislumbrado na sua produção artística, particularmente nas obras que pertencem ao período de 1910 a 1917 - coincidentemente a fase metafísica de De Chirico.

Por intermédio das poéticas de Böcklin e Klinger, o jovem De Chirico familiariza-se com uma estética do sentimento melancólico. Assimila a faculdade de aliar elementos naturais e sobrenaturais; o cotidiano e o mítico; a tradição e a inovação. De Nietzsche e Shopenhauer, o pintor incorpora os conceitos de stimmung, de enigma, da angústia do labirinto, da "revelação" e da meditação sobre a existência. Para De Chirico, a técnica de deslocamento de Böcklin (onde o mito se faz presente na atualidade) é dotada de um efeito similar aquele consolidado na prosa de Nietzsche. No seu processo criativo, é perceptível o emprego do conteúdo filosófico que preza em Nietzsche, bem como dos suportes estéticos encontrados em Böcklin para elaborar uma poética baseada no sentimento melancólico-romântico repleto de metáforas. 
Da natureza do artista e do seu estado de saúde, narrados em suas memórias, extrai-se uma pré-disposição do jovem De Chirico ao estado melancólico. Sua trajetória pessoal é marcada por diversas crises existenciais e disfunções orgânicas (próprias da descrição do gênio melancólico). A "revelação" na Piazza Santa Croce (Florença), em 1910, expressa o simbolismo tradicional do "complexo melancólico" (o outono, o tempo frio e seco, o crepúsculo com sombras alongadas e a presença da arquitetura clássica). Nesse cenário, De Chirico está convalescente dos problemas ocasionados pela atrabilis. De suas frequentes viagens, desde a infância, emergem memórias ligadas à partida, à ruptura com o estabelecido e à eterna expectativa pelo que o virá. A metáfora da viagem está associada também ao “complexo melancólico".

O ano de 1905 marca profundamente a vida de Giorgio De Chirico. A morte de seu pai - figura de forte influência sobre a personalidade do artista provoca uma perda de referência para toda a família. No advento da I Guerra Mundial, os irmãos De Chirico (nascidos na Grécia, mas filhos de pais italianos), viram no alistamento uma oportunidade de legitimar sua identidade. Vista na época como a solução radical para os conflitos, a I Guerra resultou, numa grande desilusão, notadamente, para intelectuais e artistas do período. O conjunto desses fatores contribui, substancialmente, para o estado melancólico do artista.

O estado melancólico está presente, textualmente, em algumas obras, em outras surge como atmosfera. Em todas estão presentes os "signos solitários". Esses signos correspondem às emergências do universo moderno. De Chirico incorpora em suas obras símbolos, tais como: as arcadas, as praças italianas, os gladiadores, os cavalos, o trem, as torres, as chaminés, os manequins, entre outros. São elementos extraídos da mitologia e da arquitetura greco-romana somados à vida moderna e aos desdobramentos de uma geração "sem perspectivas" (em ruínas), sem a crença no progresso existente nos séculos anteriores. A produção de Giorgio De Chirico revisita o legado cultural (a mitologia helênica e latina). Através de uma "reciclagem histórica", o artista organiza imagens canônicas, selecionadas durante a História da Arte Ocidental. Na utilização de uma "mitologia pessoal”, De Chirico e família desdobram-se em 
diversos personagens: Jasão e os Argonautas, Dióscuros, Ariadnes, Gladiadores, Musas, entre outros. Esses mitos representam o retorno ao passado e o questionamento do futuro cercado por ícones do progresso, tais como: chaminés e trens. Sua iconografia sustenta-se pelo "retorno à ordem" que o pintor reivindica desde 1910 - uma vontade de pensar o futuro da pintura como repetição de seu passado. Representa, ainda, a tentativa de reconstruir uma forma definida e contida em um espaço, delimitado e organizado, de acordo com referências claras e sólidas de um ofício que acredita inspirar-se nas técnicas antigas.

De Chirico, baseado na tradição lírica da melancolia, vê no poeta o ser capaz, o predestinado a desvendar a verdadeira realidade, a realidade metafísica. Busca ser não somente o pintor-poeta, mas, também, o pintor- profeta (e ainda, o viajante, o explorador), aquele que revela em sua poética a "solidão dos signos", ou seja, composições imprevisíveis pela disjunção do signo (a separação do seu significado imediato), gerando a sensação de estranhamento e verdadeiros enigmas para o observador, assim como procura desenvolver o mecanismo da "revelação". De Chirico procura inserir o stimmung em suas telas, bem como a revelação plástica, que se dá de forma muda. Por isso, adverte que: diante de uma pintura profunda deve-se calar, para que a emergência de novos sentidos possa acontecer livremente. O que é a revelação para De Chirico se não o resultado da desordem dos nexos? No mecanismo de revelação, a pintura metafísica torna-se imortal porque reflete sobre o enigma da passagem da vida para a morte. Ela contempla e faz contemplar o estado atemporal - o perpétuo instante.

No mundo metafísico, os objetos tomam a cena. O humano é mediado pelos objetos. A profusão dos objetos presente na iconografia de Dürer, Watteau, Vien (e em todos os herdeiros de saturno) se manifesta, também, nas telas de Giorgio De Chirico. Não somente o ser contempla os objetos sem utilidade, por vezes o ser é coisificado (estátuas e manequins). O que prevalece são os objetos, aparentemente, sem relações entre si. Os objetos se somam à dimensão arquitetônica (praças vazias, arcos, interiores, cidades desoladas fortemente geometrizadas) que não são outra coisa se não a busca de uma modernidade 
através da releitura das raízes clássicas. Para De Chirico, Ariadne (eleita como sua alegoria, enfaticamente, conectada à melancolia), pode orientar artista e expectador a transpor o labirinto da modernidade (o desvelar do mito).

A subversão da perspectiva, a luz crepuscular e as sombras projetadas, à primeira vista, são elementos retirados da História da Arte, mas num segundo momento, denunciam a modernidade presente na obra de De Chirico. A renúncia da harmonia propiciada pela perspectiva quatrocentista e o jogo de luzes e sombras atribuem à cena dramaticidade e clima de pesadelo - uma realidade enfraquecida. Tudo remete à aparente ausência do humano. O sentimento melancólico surge desse estado de coisas (do exame do mundo existencial frente ao mundo real!). $\mathrm{O}$ aspecto enigmático proposto pelo artista emprega a "razão para retratar justamente o que ela não pode conhecer": uma realidade distante, outra dimensão, na qual se encontra o mistério da própria vida. ${ }^{2}$

Em síntese, as questões estéticas da melancolia na obra de Giorgio De Chirico, examinadas neste trabalho, mostram que a melancolia moderna, expressa pelo artista é radical: evoca a desilusão frente aos componentes do progresso. Ela é o pressentimento de que nenhuma matéria universal pode reordenar e reunir os elementos do real. Ela é a consciência do homem moderno. Consciência esta de que nenhuma norma (racional ou estética) pode unir as manifestações dispersas do conhecimento e, por sua vez, livrá-lo da entrega ao estado melancólico.

\footnotetext{
2 BEJERMAN, Ingrid. “Trazendo a sombra à luz”. Acesso em: www.estado.com.br/edicao/especial/chirico/arte.html.
} 


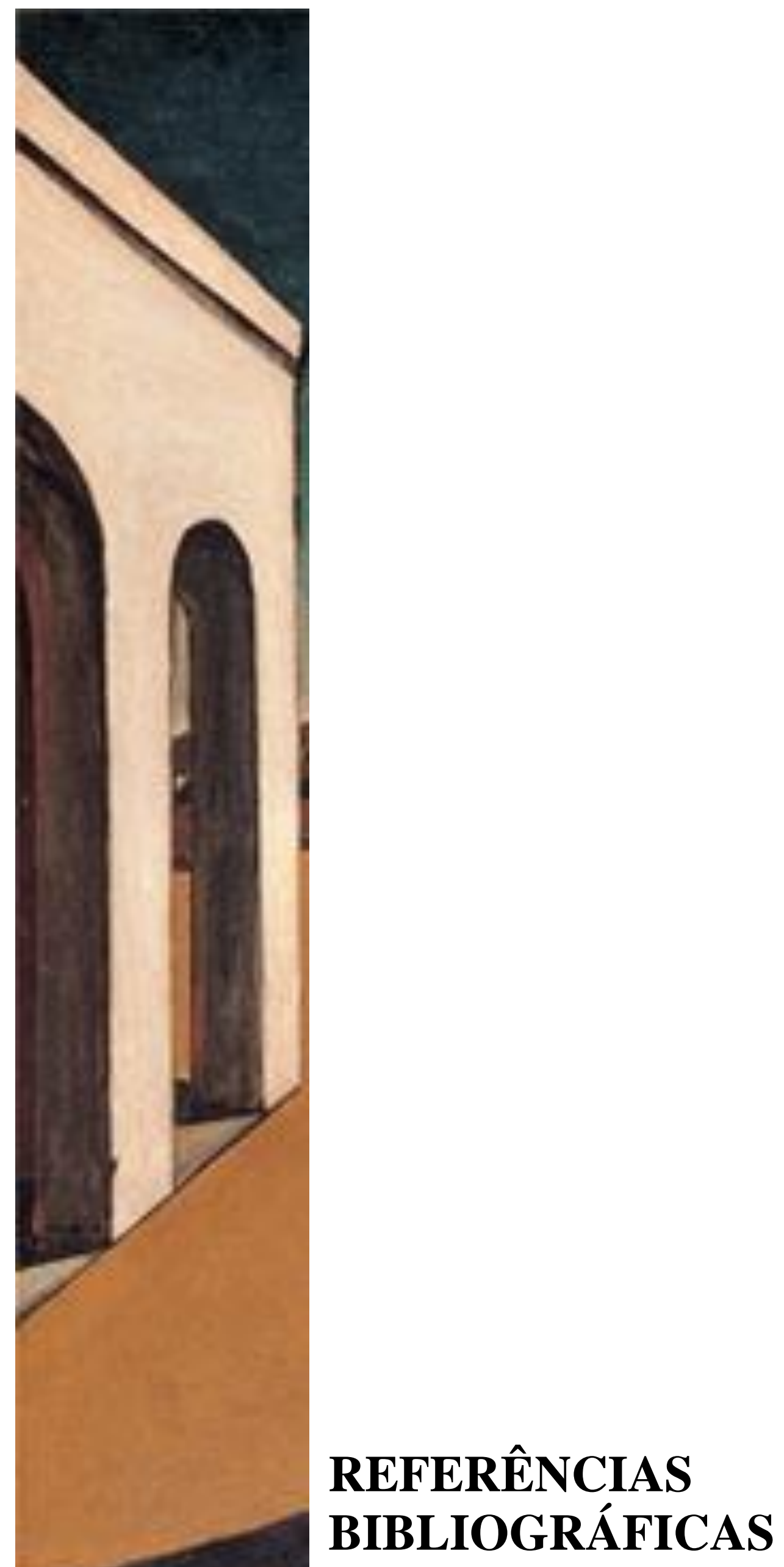


AGRIPPA VON NETTESHEIM, Heinrich Cornelius. De La Philosophie Occulte. Paris: Armand Collin, 1922.

AJZENBERG, Elza. Ciccillo: Acervo MAC USP - Homenagem a Francisco Matarazzo Sobrinho. São Paulo: MAC USP, 2006.

. MAC Virtual: Prêmios Bienais. São Paulo: MAC USP, 2004.

ARIKHA, Noga "La Mélancolie et les Passions Humorales". In: GALERIES NATIONALES DU GRAND PALAIS, Mélancolie: Genie et Folie en Occident. Paris: Gallimard, 2005.

ARISTÓTELES. Problèmes. Tome III, Problema XXX, 953 a 10. Sections XXVII à XXXVIII et index. Texte et traduit par Pierre Louis. Paris, Les Belles Lettres, 1994.

ARGAN, Giulio Carlo. Arte Moderna. São Paulo: Companhia das Letras, 1992. . História da Arte Italiana. São Paulo: Cosac \& Naify, 2003.

- Clásico Anticlassico: Il Rinascimento da Brunalleschi a Bruegel. Milano: Feltrinelli, 1984.

ARTE. Speciale - II Secolo lungo della pittura italiana. Milano: Editoriale Giorgio Mondadori, agosto de 2004.

BALDACCI, Paolo. De Chirico.The Metaphysical Period (1888-1919). Boston/New York/Toronto/London: A Bulfinch Press Book/Little/Brown and Company, 1997.

. The Function of Nietzsche's thought in de Chirico's art in: Nietzsche and na Architecture o four minds. Editado por Alexandre Kotska e Irving Wohl Farth Los Angeles; Getty Research Institute for the History of Art and the Humanities, 1999.

BARBOSA, Paulo Roberto Amaral. Giorgio De Chirico no Acervo MAC USP. São Paulo: ECA USP, 2006 (Dissertação de Mestrado).

BAUDELAIRE, Charles. “Os faróis”, em Flores do Mal, 1857 (Trad. Ivan Junqueira)

BENJAMIN, Walter. Origine du Drame Barroque Allemand. Paris: Flammarion, 1985. . One-way street and other writings. Londres, 1979. 
BERLINCK, Luciana Chauí. Melancolia: Rastros de Dor e de Perda. São Paulo: Humanitas, 2008. FICINO, Marsílio. Book of Life. Woodstock: Spring Publications, 1996.

BOERLIN-BRODECK, Yvonne,“A figura numa paisagem”. In: Antoine Watteau (1684 - 1721). The painter, his age and his legend. Paris/Genebra, 1987, p.167-169.

BRETON, André. Position Politique du Surréalisme. Paris: Denöel/Gonthier, 1972.

BURTON, Robert. The Anatomy of Melancholy. Nova York: Farrar \& Rinehart, 1927.

BRHIGHT, Timothy. Traité de La Mélancolie, 1586. Trad. E Cuvellier, Paris, Jérôme Millon, 1996, p. 32

CAIROLA, Stefano. Arte Italiana del Nostro Tempo. Bergamo: Istituto Italiano d'Arti Grafiche, 1946.

CASABAN, Consuelo Císcar (org.). El Siglo de Giorgio De Chirico: Metafísica y Arquitectura. Valencia: IVAM, 2007.

CEZARETTI, Maria Elisa Linardi de Oliveira. Olhar em Suspensão: Giorgio Morandi e a Natureza Morta. São Paulo: ECA USP, 2002 (Tese de Doutorado).

CLAIR, Jean. "Maquinismo e Melancolia". In: In: GALERIES NATIONALES DU GRAND PALAIS, Mélancolie: Genie et Folie en Occident. Paris: Gallimard, 2005.

CLARET, Martin. O Pensamento Vivo de Picasso. São Paulo: Martin Claret Editores, 1985.

COELHO, Teixeira. O Brasil no Século da Arte - A Coleção MAC USP. São Paulo: MAC USP/AAMAC, 2000.

. MAC Collection. São Paulo: Comunique Assessoria, 2006.

DE CHIRICO, Giorgio. "Meditações de um Pintor, 1912”. In: CHIPP, H.B. Teorias da Arte Moderna, São Paulo: Martins Fontes, 1996. 
1971.

. The Memoirs of Giorgio De Chirico. Londres: Peter Owen Limited,

Il Meccanismo Del pensiero. Critica Polêmica - Autobiografia de 19111943. Maurizio Fagiolo (ed.), Einaude, Turim, 1985.

. "Sull'arte metafísica". Valori Plastici (Roma), 1, 4-5 (abr/maio de 1909),

pp. $15-25$. . Memorie della mia vitta. Roma: Rizolli, 1962.

DE CHIRICO, Marise. Em Torno de De Chirico: "Diagramas" Possíveis. São Paulo: UNESP, 2000 (Dissertação de Mestrado).

DEMPSEY, Charles. The Portrayal of Love. Botticelli's Primavera and the culture at the time of Lorenzo the Magnificent. Princeton University Press, 1992.

Dictionnaire universel françois et latin vulgairement appelé dictionnaire de Trévoux... nouvelle édition, Paris, 1771, t. V.

DIDEROT, Denis. Salão de 1765, edição de Else Marie Bukdahl e Annette Lorenceau, Paris, Hermann, 1984.

FAGIOLO DELL'ARCO, Maurízio. L'Opera Completa di De Chirico. 1908-1924, Clacissi dell'Arte Rizzoli, Milano, 1984.

. Giorgio De Chirico Il Tempo di Apollinaire - Paris 1911/1915: Roma: De

Luca Editore, 1981.

FAROULT, Guilherme. "La Douce Mélancolie - Selon Watteau et Diderot Représentations Mélancoliques dans les Arts en France au XVIII Siècle". In: GALERIES NATIONALES DU GRAND PALAIS, Mélancolie: Genie et Folie en Occident. Paris: Gallimard, 2005.

FERRAND Jacques. De La Maladie d'Amour ou Mélancholie Érotique. Discours Curieux qui Enseigne à Cognoistre l'Essence, les Caises, les Signes et les Remèdes de ce Mal Fantisque.Paris, 1623, p. 46-47.

FICINO, Marsílio. Book of Life. Woodstock: Spring Publications, 1996. 
FIORAVANTE, Celso. "Mostra vê o sonho de De Chirico". Folha de S. Paulo. São Paulo, 16 mar. 1988.

FERRAND Jacques. De La Maladie d'Amour ou Mélancholie Érotique. Discours Curieux qui Enseigne à Cognoistre l'Essence, les Caises, les Signes et les Remèdes de ce Mal Fantisque.Paris, 1623.

FURETIÈRE, Antoine. Dictionnaire universel... La Haye e Rotterdam, 1690.

Grand Dictionnaire historique de Moreri, Paris, 1725. In: ROSENBERG, Pierre. Vies anciennes de Watteau, Paris, 1984.

GLORIEUX, Guillaume. À l'enseigne de Gersaint. Edme-François Gersaint, marchand d'art sur le pont Notre-Dame (1690-1750), Seyssel, Champ Vallon, 2002, p.90-113.

GONCOURT, Edmond e Jules. "La philosophie de Watteau", o Artista, 7 de set. 1856, p. $127-129$.

HOBSBAWM, Era dos Extremos: O Breve Século XX 1914-1991. São Paulo: Companhia das Letras, 1995.

HOLZHEY, M. De Chirico (1888-1978): Le mythe moderne. Paris: Taschen, 2005.

KRISTEVA, Julio. Sol Negro: Depressão e Melancolia. Rio de Janeiro: Rocco, 1989.

LAMBOTTE, Marie-Claude. Estética da Melancolia. Rio de Janeiro: Companhia Freud, 2000.

LEIGHTEM, Patrícia. Re-ordering the universe, Picasso and anarchism, 1897-1914. Princeton, Princeton University Press, 1989.

LISTA, Giovanni, Giorgio De Chirico: Suivi de L'Art Métaphysique. Paris: Éditions Hazan, 2009.

LOPES, Oneide. "De Chirico - Um caso curioso na história da Arte". Diário da Manhã, Goiânia, 22 nov. 1983. 
LOWY, Michael. Walter Benjamin: Aviso de Incêndio - Uma Leitura das Teses "Sobre o Conceito de História”. São Paulo: Boitempo, 2005.

MEDEIROS, Sérgio. "Enigma de De Chirico inspira filme brasileiro". O Estado de $S$. Paulo, 21 abr. 1994.

MICHALSKI, Sergiusz. "Sombras de soledad, sombras de amenaza". IN: STOICHITA, Victor I. La Sombra. Madrid: Museo Thyssen-Bornemisza, 2009

MUSEU DE ARTE CONTEMPORÂNEA DA UNIVERSIDADE DE SÃO PAULO. Perfil de um Acervo. São Paulo: Techint, 1988.

MUSEU DE ARTE CONTEMPORÂNEA DA UNIVERSIDADE DE SÃO PAULO. MAC Collection. São Paulo: Comunique Editorial, 2003.

NADEAU, Maurice. Historia del Surrealismo. Buenos Aires: S. Rueda, 1948.

NIETZCHE, Frederic. Ainsi Parlait Zarathoustra. Paris: Mercure France, 1914. . Obras Completas. São Paulo: Abril Cultural, 1983.

O MUSEU DE ARTE CONTEMPORÂNEA DA UNIVERSIDADE DE SÃO PAULO. São Paulo: Banco Safra, 1990

PANOFSKY, Erwin. La Perspectiva como "forma simbólica". Barcelona: Tusquets Editor, 1973.

. Saturn and Melancholy, ed. by H.W. Janson, 1964.

PAZ, Octavio. "Picasso: O Corpo a Corpo com a Pintura". Esse texto escrito originalmente para o catálogo da exposição Los Picassos de Picasso, que inaugurou em 1982 o Museu Rufino Tamayo (México) e editado no volume Sombras de obras, que reúne vários ensaios de Octavio Paz.

PIGEAU, Jackie. Metáfora e Melancolia: ensaios médico-filosóficos. Rio de Janeiro: PUC Rio/Contraponto, 2009.

POSNER, Donald. "Watteau melancólico: a formação de um mito". In: Bulletin de la Société de l'histoire de l'art Français, 1974, p.345-361. 
SCLIAR, Moacyr. Saturno nos Trópicos: A Melancolia Européia Chega ao Brasil. São Paulo: Companhia das Letras, 2003.

SEVCENKO, Nicolau. "Exposição Mostra Fúria da Arte Italiana do Século 20”. Folha de S. Paulo, s/d.

. O Renascimento. São Paulo: Atual, 1994 (Discutindo a história).

- Orfeu Extático na Metrópole: São Paulo sociedade e cultura nos

frementes anos 20. São Paulo: Companhia das Letras,1992.

SOlOMON, Andrew. O Demônio do Meio-Dia: Uma Anatomia da Depressão. Rio de Janeiro: Objetiva, 2002.

STAROBINSKI, Jean. “L'Encre de la Mélancolie”. In: GALERIES NATIONALES DU GRAND PALAIS, Mélancolie: Genie et Folie en Occident. Paris: Gallimard, 2005.

. Histoire du traitement de la mélancolie des origines à 1900, Bâle: Geigy, 1960.

STOICHITA, Victor I. La Sombra. Madrid: Museo Thyssen-Bornemisza, 2009.

TAYLOR, Joshua Charles. Futurism. New York: Museum of Modern Art, 1961.

YATES, Frances A. Giordano Bruno and the hermetic tradition. Chicago: University of Chicago Press, 1982.

\section{Sites:}

ALVARENGA, Aline. "Melancolia, esperança e genialidade ou melancolia generosa". www.constelar.com.br. Acesso em 24 de julho de 2007.

Arnold Böcklin. In Infopédia. Porto: Porto Editora, 2003-2010. Disponível na www: <URL: http://www.infopedia.pt/\$arnold-bocklin>. Acesso em 02 de dezembro de 2010. 
BEJERMAN, Ingrid. "Trazendo a sombra à luz". Acesse em: www.estado.com.br/edicao/especial/chirico/arte.html.

GUERREIRO, Walter de Queiroz. Metafísica além da vigília. Especial para o Anexo. www.anexo.com.br. Acesso em 20 de julho de 2004.

www.fundacaoisaegiorgiodechirico.it. Acesso em 21 de agosto de 2006.

www.mac.usp.br/projetos/séculoxx. Acesso em 15 de outubro de 2005.

www.max-klinger.com/. Acesso em 23 de dezembro de 2010.

www.paideiaonline.org/. Acesso em 23 de dezembro de 2010.

www.studio-international.co.uk/painting/Chirico.asp. Acesso em 23 de dezembro de 2010. 


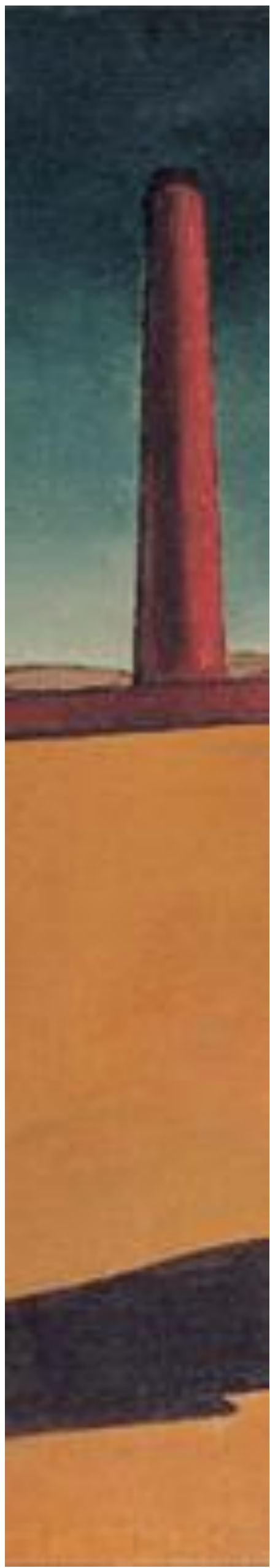

ANEXO 


\section{Biografia do Giorgio de Chirico}

1888-1890

Giuseppe Maria Alberto

Giorgio de Chirico nasceu em Volos (Tessália) em 10 de julho de 1888. Seu pai, Evaristo de Chirico, era italiano da Sicília (filho do Barão Giorgio Filigone de Chirico, que tinha representado o Regno di Sardegna em Constantinopla); sua mãe, Gemma Cervetto, era genovesa. Seu pai, engenheiro de estrada de ferro, trabalhou na construção da rede de

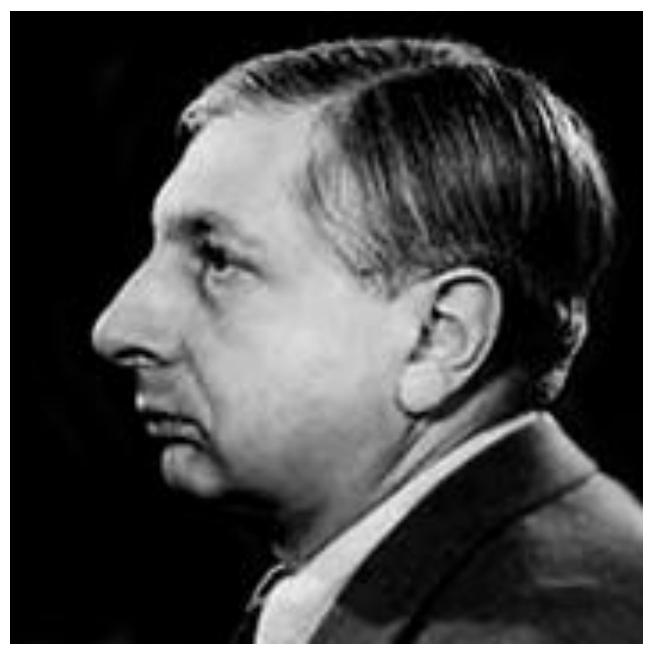
ferroviária na Tessália.

\section{1-1898}

Adelaide, irmã mais velha de Giorgio, morreu em março; seu irmão mais novo, Andrea, nasceu, no mês de agosto, em Atenas (onde a família de De Chirico morou temporariamente). Andrea adotou o pseudônimo Alberto Savinio em 1914. Em 1896 os de Chirico retornaram para Volos onde ficaram até 1899. Giorgio De Chirico teve suas primeiras lições de pintura, em Volos, com o pintor grego Mavrudis, a seguir teve lições com Carlo Barbieri e Jules-Louis Guilliéron (um artista suíço especializado em pintura das ruínas antigas).

\section{9-1905}

Os De Chirico mudaram-se para Atenas novamente, onde o seu pai supervisionava a construção da linha da estrada de ferro Atenas-Salonika. Depois de frequentar por pouco tempo o Liceu Leonino, administrado por jesuítas, Giorgio recomeçou os seus estudos com professores particulares. Os dois irmãos estudaram italiano, alemão, francês, música e praticaram ginástica. Em 1900, Giorgio fez sua primeira pintura, uma natureza-morta com limões. Matriculado na Politécnica de 1903 a 1906, frequentou o curso de desenho oferecido por Constantino Volonakis e Giorgio Roïlos, e depois um curso de pintura oferecido pelo pintor retratista Georges Jakobidis, que veio da Academia de Munique. Em Atenas, manteve amizade com jovens artistas: Stavros 
Kanzikis, Dimitrios Pikionis e Giorgio Bousianis. Em maio de 1905, o seu pai faleceu.

\section{6-1909}

Em setembro de 1906, sua mãe decidiu deixar a Grécia. Pararam brevemente na Itália, e visitaram Veneza e Milão. Em outubro, a família de Chirico mudou-se para Munique. Giorgio frequentou a Academia de Belas Artes, estudando com o professor Dr. Gabriel Ritter von Hackl, enquanto Andrea continuou os seus estudos de música. Giorgio De Chirico se tornou muito interessado em Arnold Böcklin e Max Klinger, e leu Friedrick Nietzsche, Arthur Shopenhauer e Otto Weininger. Travou conhecimento, com Fritz Gartz, seu colega de trabalho. Em 12 de dezembro, De Chirico, através de carta, pediu para participar da Bienal de Veneza de 1907.

Em fevereiro 1907, sua mãe e Andrea voltaram para Itália: primeiro para Roma, depois para Milão (Via Petrarca). Andrea pôde aperfeiçoar os seus estudos musicais. Giorgio ficou em Munique, onde visitou museus e galerias. Fez cursos com o professor Dr. Carl von Marr. Entre 16 de julho e 3 de outubro de 1908, encontrou sua mãe e irmão, primeiro no lago Garda, depois em Milão, nas suas férias de verão. Naquela época, Giorgio fez suas primeiras telas com inspiração dos Nabis e de Böcklin. Voltou para a Alemanha no começo de outubro.

No final do verão de 1909, mudou-se para Via Petrarca em Milão. Em outubro, viajou para Florença e Roma, e escreveu sobre isso para o seu amigo Fritz Gartz em Munique. Leu muito, especialmente os trabalhos de Nietzsche.

\section{0}

Giorgio e Alberto mudaram-se para Florença (Via Lorenzo il Magnífico e fixaram o seu atelier na Viale Regina Vittoria, hoje Viale Don Minzoni) em janeiro. Entre o inverno e o verão, Giorgio, que estava sofrendo de melancolia, foi morar em Vallombrosa, uma vila nos altos de Florença, para se recuperar de sua doença. Em Florença, ficou profundamente impressionado com a arquitetura de Brunelleschi, retomou os seus estudos sobre Nietzsche, e pintou o seu primeiro trabalho metafísico: Énigme d'un après-midi d'automne. 


\section{1}

Em 15 de janeiro, Andrea e sua mãe chegaram à Munique. Entre abril e maio, Giorgio foi para Roma em uma segunda viagem. Em 14 de julho, Giorgio e sua mãe encontraram Andrea em Paris depois de uma passagem por Turim. Nesta passagem Giorgio lembrou Friedrich Nietzsche especialmente, sua demência em Turim. Nessa cidade, marcos históricos tornaram-se temas iconográficos em sua pintura, incluindo o Mole Antonelliana, a torre situada no pátio do Palazzo Carignano, assim como o monumento equestre de Carlo Alberto. Durante esse ano a família de De Chirico mudou de residência cinco vezes. De Chirico sofreu com leves distúrbios psicossomáticos causados pelas contínuas mudanças e foi para Vicky para um breve tratamento (final de setembro e começo de outubro). Neste período, o seu irmão fez contato com o círculo musical e artístico parisiense. Lá, Andrea conheceu Michele Demetrio Calvocoressi, uma famosa musicóloga.

\section{2}

Arianna addormentata, uma cópia do original no Museu do Vaticano, executada por Corneille Van Clève, em 1688, no jardim Versailles, deu a De Chirico um novo ponto de vista para sua iconográfica metafísica. Em 2 de março, retornou a Turim para servir o exército, mas relutou ao serviço militar. Dez dias, como soldado, foram suficientes para convencê-lo a fugir para Paris.

A primeira participação de De Chirico numa exposição - o Salão d'Automne (Gran Palais, Paris, outubro-novembro) - data daquele outubro, graças ao interesse da crítica musical grega Michele Demetrio Calvocoressi que o apresentou a Pierre Laprade (um pintor e membro do júri do Salão). De Chirico mostrou o Autoportrait e duas composições, Énigme de I'Oracle e Énigm d'um après-midi d'automne. Recebeu bons comentários dos críticos Louis Vauxcelles ("Gil Blas", 30 de setembro), Roger Allard ("La cote", 18 de outubro) e Francis de Miomandre ("Les Arts et les Artistes"). Talvez para retomar os seus estudos acadêmicos interrompidos em Munique, De Chirico mudou-se para a rua Mazarine, 43, perto da rua Bonaparte, onde a Escola de Belas-Artes tinha os seus edifícios. Cabeças e moldes de gipsita apareceram como temas metafísicos nas suas pinturas. 


\section{3}

De Chirico exibiu três pinturas no Salon des Independants (março-abril): Mélancolie du départ, Énigme de l'heure, Énigme de l'arrivée et de l'aprés-midi. Picasso e Guillaume Apollinaire viram os seus trabalhos durante a visita ao Salon. Foram até o seu atelier, onde viram vários trabalhos. Também recebeu comentários muito relevantes de Louis Vauxcelles ("Gil Blas", 18 de março) e Roger Marx. Apoillinaire apresentou-o para Ardengo Soffici, Fernand Léger, Constanti Brancusi, Max Jacob, André Derain e Georges Braque. De Chirico aproximou-se de algumas pessoas da revista Les Soirées de Pariz. Em outubro, Apollinaire e De Chirico organizaram mostra sobre a obra de alguns artistas (umas trinta pinturas a óleo) no seu estúdio (Rua Notre-Dame-des-Champs, 115). Em 9 de outubro, Apollinaire, escrevendo sobre De Chirico, em L'Intransigeant e outras revistas, usou a palavra "metafísico". Exibiu no Salon d'Automne (Grand Palais, Paris, novembro-janeiro): Portrait de Mme L. Gartzen, La Mélancolie d'une belle journée, La Tour rouge, Étude. Naquela ocasião, vendeu sua primeira tela (provavelmente La Tour rouge ou La Mélancolie d'une belle journée) para Olivier Senn, um colecionador de Le Havre. Em meados de novembro, por intermédio de Apollinaire, De Chirico conheceu Paul Guillaume, o seu primeiro marchand, com quem assinou um contrato por cem francos mensais. Concluiu os seus estudos sobre Schopenhauer.

\section{4}

Exibiu no Salon des Indépendants (março-abril): La nostalgie de l'infini, Joies et énigmes d'une heure étrange, Énigme d'une journée. Na primavera, pintou o seu famoso Portrait of Apollinaire. Por essa tela, Apollinaire dedicou-lhe o poema Océan de Terre (1915).

Em maio, Savinio ofereceu um concerto para Siorées de Paris, e Apollinaire escreveu um longo artigo. Ardengo Soffici escreveu sobre os dois irmãos De Chirico, pela primeira vez, em uma revista italiana (Lacerba, $1^{\circ}$ de julho de 1914). Em agosto começou a guerra. Apollinaire foi para o front, o grupo de amigos de De Chirico se separou; Braque e Derain deixaram a França. Em novembro, Paul Guillaume colocou De Chirico em contato com Alfred Stieglitz, dono de galeria em Nova York. Por volta do final de 1914 ou no começo de 1915, Stieglitz organizou uma mostra para De Chirico em sua galeria nova-iorquina (Galeria 291). O artista mudou o seu estúdio para a Rua Campagne-Première, 9, não tão distante dos ateliês de Fernand 
Léger e do fotógrafo Eugène Atget e outros protagonistas da vanguarda. Começou o seu último ciclo iconográfico parisiense com os Manequins.

\section{5-1916}

No verão, de Chirico e Savinio foram convocados pelas autoridades militares italianas e se alistaram. Foram mandados primeiro para Florença, e depois para Ferrara $\left(27^{\circ}\right.$ Regimento de Infantaria Caserna Pollastrini). Após um surto de depressão, Giorgio foi declarado inválido para ações militares e incumbido para ser secretário no caixa do escritório do Hospital Militar Villa Del Seminário. A sua mãe o encontrou em Ferrara, onde foi instalado na casa de uma família local. De Chirico manteve os seus contatos com Paul Guillaume, com quem renovou o seu contrato. Ele deixou Giuseppe Ungaretti - que saiu do estúdio de De Chirico na Rua Campagne-Première - com as telas deixadas em Paris. Ungaretti vendeu algumas delas para André Breton e deixou outras, além de documentos e objetos com Jean Paulhan (escritor e poeta), que era amigo de Apollinaire e vivia na mesma rua onde De Chirico tinha um estúdio. De Chirico perguntou se Ungaretti gostaria de vender junto com Paulhan suas telas produzidas em Paris. Em outubro de 1915, a mãe de De Chirico visitou o estúdio do filho. Fez essa viagem à Paris especificamente para dar a Paul Guillaume algumas telas, assim como enviar aqueles trabalhos que Giorgio gostaria de ter na Itália.

De Chirico entrou em contato com o grupo Dadá; escreveu para Zayas, enviando-lhe um desenho para a revista Dadá 291. Em Ferrara, conheceu Conrado Govoni para quem dedicou o poema Il signor Govoni dorme e Filippo de Pisis, que lhe dedicou o primeiro artigo de sua monografia (Gazzetta Ferrarese, 11 de outubro de 1916). Conheceu os poetas e pintores do Gruppo di Ferrara, e através de Govoni teve contato com Ravegnani, De Paoli, Luppis, Neppi e Elvira Fabbri. Com esta, teve um romance, desaprovado por sua mãe. De Chirico foi apresentado para o círculo de Ferrara, uma cidade com tradição esotérica e alquimista, onde morava uma importante comunidade judaica. Em 1916, através de Ardengo Soffici, entrou em contato com Carlo Carrà. A primeira carta do artista para Carrà data de 27 de fevereiro de 1916. 
Tristan Tzara contatou De Chirico e pediu-lhe um trabalho para a primeira exposição Dadá em Zurique (Galeria Corray, janeiro), mas De Chirico não participou da mostra, talvez, por causa dos contratempos com Paul Guillaume. Participou de uma exposição de gráficos em Zurique (Ausstellung von Graphik, Broderie, Relief, Galeria Dadá, em maio), e deu um desenho para Tzara. Dadá II (dezembro) publicou um de seus trabalhos (Le Mauvais Génie d'un Roi). Por causa de desordens nervosas, do final de janeiro até a primavera, De Chirico ficou com Carlo Carrà no Hospital Militar de Ferrara (Villa Del Seminário). Participou de discussões artísticas calorosas com Carrà e Savinio. Nessa época, Carrà fez suas primeiras pinturas com temas em comum e inspirada em De Chirico. Este foi o ano do nascimento do que mais tarde seria chamado de "Pintura Metafísica". De Chirico pintou o primeiro Metaphysical Interiors, Grand Metaphysicians, Hector and Andromache series, The Troubadour, The Disquieting Muses. De 9 a 12 de abril, participou de uma exposição coletiva com obras da coleção Léonide Massine no salão do Teatro Costanzi em Roma, na ocasião dos Ballets Russes. Através do pintor ferrarense Roberto Melli, De Chirico conheceu Mario Bróglio, o criador da revista Valori Plastici, da qual de Chirico se tornou colaborador, iniciando sua edição (15 de novembro de 1918). A revista deveria assumir o papel de primeira importância no círculo da arte italiana no pós-guerra. De Chirico também contribuiu na L'Avanscoperta e La Brigata (editada por Bino Binazzi), e publicou os seus primeiros desenhos na La Brigata e La Ghirba (uma revista militar fundada e publicada por Ardengo Soffici). Em dezembro, De Chirico foi para Paris, onde encontrou Paul Guillaume e lhe entregou os trabalhos que fizera em Ferrara.

\section{8}

Embora oficialmente em Ferrara, De Chirico estava ocupado em Roma, onde morou no Hotel Park com sua mãe. Manteve contato com Enrico Prampolini, Roberto Melli e Mario Bróglio. Em maio, expôs pela primeira vez na Itália numa exposição coletiva, organizada por Mario Recchi. Outros participantes na exposição (I Mostra d'Arte Indipendente, Galleria dell'Epoca, maio-junho) foram Carlo Carrà, Ferruccio Ferrazzi, Enrico Prampolini, Vincenzo Riccardi e Ardengo Soffici. A exposição foi mencionada na revista De Stijl. De Chirico continuou a mostrar interesse em Paris; Apollinaire (que inspirado pela sua pintura criou o vocábulo "surreal") e Pierre-Albert Birot escreveram 
sobre ele e sua influência nos artistas italianos jovens. Paul Guillaume apresentou e comentou o trabalho de De Chirico no teatro Vieux Colombier em Paris (10 de novembro) na ocasião da manifestação organizada pelo grupo Dadá, Art et Liberte. Jean Cocteau viu pela primeira vez as pinturas de De Chirico. Fez o seu primeiro autorretrato clássico. Em 15 de novembro, foi lançada a primeira edição de Valori Plastici (a revista de arte de Mario Bróglio). Dentre os contribuintes, estavam Carrà, Savinio, Soffici, Morandi e mais alguns artistas e críticos estrangeiros. De Chirico publicou Zeusi l'esploratore nessa sua edição; e artigos teóricos sobre metafísica nas edições seguintes.

\section{9-1920}

Colaborou com Savinio para a revista de Prampolini Noi. Em fevereiro, fez sua primeira exposição individual em Roma (Casa d'Arte Bragaglia). Para esta mostra, de Chirico publicou o seu texto Noi metafisici na edição de fevereiro de Cronache d'Attualità. A mostra não teve muito sucesso, sendo Pisis o único a dar um comentário favorável (Disegni di Giorgio de Chirico, "La Provincia di Ferrara", 21 de fevereiro), enquanto Roberto Longui criticou (Al dio ortopedico, "Il Tempo", 22 de fevereiro). Frequentou os salões de Armando Spadini, Riccardo Bacchelli, Vincenzo Cardarelli e Olga Signorelli. Em Roma, foi convidado a dividir o estúdio de Arturo Martini, e mais tarde dividiu um com Domenico Bertoli, na Via degli Orti d'Alibert. No outono, assinou um contrato exclusivo com Bróglio para o seu trabalho pictorial e literário. A primeira monografia do trabalho de De Chirico foi publicada (Giorgio de Chirico. 12 tavole in fototipia precedute da giudizi critici, Edizioni di Valori Plastici, Roma). O livro incluía uma antologia com textos de Ardengo Soffici, Guillaume Apollinaire, André Salmon, Etienne Charles, Roger Marx, Maurice Raynal, Carlo Carrà, Giovanni Papini, Jacques-Émile Blanche e Louis Vauxcelles.

André Breton fez um artigo expressivo na Littérature, em 28 de janeiro de 1920. André Breton e Paul Eluard deram início a troca de correspondência com Giorgio De Chirico. Theo van Doesburg analisou Valori Plastici no De Stijl. No começo de março de 1920, exibiu pela, primeira vez, em Milão, em uma mostra coletiva, inaugurando a Galeria Arte, apresentada por Margherita Sarfatti.

\section{1}

Morou entre Roma (onde ele usa o endereço do escritório da $L a$ Ronda como seu), Florença (convidado por Giorgio 
Castelfranco, um jovem estudante de arte e seu admirador) e Milão. Em Florença, estudou a técnica da têmpera e pintura em telas. O pintor russo Nicola Locoff iniciou-o nos segredos da têmpera esmaltada. De Chirico participou de várias mostras coletivas (Gênova, Paris, Berlim).

De 29 de janeiro a 12 de fevereiro de 1921, teve sua primeira exposição particular em Milão (Mostra personale del pittore Giorgio de Chirico, Galleria Arte): expôs alguns trabalhos metafísicos e os resultados da sua última pesquisa. $\mathrm{Na}$ introdução do catálogo, De Chirico define suas ideias sobre pintura, cópias e desenhos. A exposição causou pouco interesse, mas recebeu um bom comentário de Enrico Somaré em Il Primato Artistico Italiano. De Chirico escreveu sobre sua pesquisa e meditações na série de artigos e escritos teóricos em várias revistas, entre elas: La Ronda, Il Convegno (o artigo de De Chirico sobre o livro de Carlo Carrà La Pittura Metafisica na edição de agosto), e Valori Plastici, onde também escreveu artigos monográficos sobre Arnold Böcklin, Max Klinger, Adolf Manzel, Hans Thoma, Pierre-Auguste Renoir e Raphael. A imprensa estrangeira seguiu o trabalho de De Chirico com interesse: Littérature com André Breton na França, De Stijl com Theo van Doesburg na Holanda, Das Kunstblatt e Der Cicerone, com Theodor Däubler na Alemanha. Em 1921, a Bauhaus planejou uma série de panfletos sobre litografia dos artistas modernos (Russian and Italian Artists, concluído no fim de 1924): De Chirico seguiu copiando Raphael e Michelangelo e se interessou pela arte do século XV. Pintou uma nova série de natureza-morta.

\section{2}

Em 21 de março, participou de uma exposição individual na Galeria Paul Guillaume com 55 obras de arte. Breton escreveu a apresentação na qual apresentou as obras no contexto surrealista. De Chirico se juntou ao grupo de Breton e foi retratado na pintura de Max Ernst Au rendez-vous des amis. Sua carta para Breton foi publicada na edição de março da Littérature. Apesar do fato de seus laços com Valori Plastici terem enfraquecendo, De Chirico participou da La Fiorentina Primaverile (Florence, Palazzo del Parco di San Gallo, março-julho) com o grupo Valori Plastici (Carrà, Morandi, Carlo Socrate, Arturo Martini, Cipriano Efisio Oppo, Armando Spadini, Edita Broglio). A exposição foi organizada por Broglio e apresentada por Morandi. 


\section{3-1924}

Continuou morando com sua mãe entre Roma e Florença (sempre como convidado do seu amigo Castelfranco, que conhecera em Milão depois da guerra). Participou da Bienal de Roma (II Biennale Romana, Roma, Palazzo delle Esposizioni, outubro de 1923) e da Turin Quadriennale.

Em 1923 Paul Eluard e sua esposa Gala, que veio para Roma especificamente para ver suas obras, compraram vários quadros e estreitaram uma amizade com ele.

De Chirico contribuiu com a revista La Bilancia de Roma, seu texto Pro technica oratio apareceu nas edições no. 1 e 2 (março e abril). Expôs duas pinturas (Ottobrata e Duelli a morte) na XIV Bienal de Veneza de 1924. Os críticos não foram favoráveis. Em Roma, onde viveu com sua mãe e seu irmão na Via Appennini, 285b, conheceu Raissa Gurievich Frol (que se tornou sua primeira esposa), uma importante bailarina em L'Histoire du soldat de Stravinskij (no teatro degli Undici, no Palazzo Odescalchi, fundado e dirigido por Pirandello). Siepe a Nord-Ovest de Massimo Bontempelli foi publicado com ilustrações de De Chirico.

Junto com Raissa, foi para Paris no outono de 1924, onde o Balé Suíço de Rolf de Maré apresentou La jarre, de Pirandello, com música do Alfredo Casella, cenário e figurino do De Chirico, no Théâtre des Champs Elysees. Seu relacionamento com os surrealistas e o ambiente artístico parisiense foram, em geral, bons. Escreveu Revê para a primeira edição da La Révolution Surréaliste (dezembro de 1924); Philippe Soupault e Luis Aragon dedicaram dois poemas para De Chirico. Seus trabalhos começaram a circular por todo o mundo. Entre seus colecionadores, incluíam-se: Paul Guillaume, Princess de Polignac, Mme Maurice Peignot, Collin d'Arbois, André Laval, Sergej Diaghilev, Allainby, de Macébo, Lefèvre, André Breton, Paul and Gala Eluard, Jacques Doucet. Expôs em Berlim (Nationalgalerie), Milão (Galleria Pesaro), Roma (Casa d'Arte Bragaglia), Veneza (XIV Bienal).

\section{5}

Na primavera, De Chirico e sua esposa se mudaram para Paris (Rua Bonaparte, depois Rua Maissonier, no Parc Monceau, e estúdio na Rua Bocquillon, 2). Raissa estudou arqueologia na Sorbonne. De Chirico, aos poucos, se afastou do cenário romano. Na primavera, contudo, não teve sucesso na III Bienal de Roma. Em maio, La morte di Niobe foi apresentada no Teatro Odescalchi em Roma, com música de Alberto Savinio, 
coreografado por Giorgio Frol, com cenário e figurino de Giorgio de Chirico. Escreveu um ensaio sobre Courbet para Valori Plastici. Os surrealistas continuaram a admirar e adquirir os trabalhos de De Chirico, entre eles: André Breton, Paul Eluard e Marcel Duchamp. De Chirico participou de uma exposição individual na galeria Léonce Rosenberg, em Paris, de 6 a 30 de maio, com apresentação de Giorgio Castelfranco. Naquela ocasião, Breton ácido em sua crítica sobre os últimos trabalhos de De Chirico. De Chirico participou, de 14 a 25 de novembro, da exposição coletiva La peinture surréaliste, na galeria, Pierre com Jean Arp, Max Ernst, Paul Klee, André Masson, Joan Miró, Pablo Picasso, Man Ray, Pierre Roy, com introdução de André Breton e Robert Desnos.

\section{6-1927}

Breton se referiu a de Chirico como um "gênio perdido", na edição no. 7 da La Révolution Surréaliste. O rompimento com os surrealistas foi completo. Somente Waldemar George, Jacques Ribemont-Dessaignes, Georges Bataille, Roger Vitrac e Jean Cocteau apoiaram De Chirico. Em julho de 1926, Savinio se mudou para Paris com sua esposa Maria Morino. Em uma carta de julho de 1926, De Chirico alertou o seu irmão, que faria sua primeira exposição individual, em outubro, na Galeria Bernheim, para não se misturar com os surrealistas, por serem eles hostis.

De Chirico começou a expor com o grupo Novecento na Itália e no exterior (Milão, Zurique, Amsterdam). Fez uma exposição individual na Galleria Pesaro em Milão e participou de exposições na Inglaterra (Galeria de Arte Brighton, Brighton), na Alemanha (Internationale Kunst Ausstellung, Dresden), e nos Estados Unidos (A Exposição Internacional de Arte Moderna, Nova York, organizada pela The Société Anonyme de Marcel Duchamp, Man Ray, Katherine Dreier). Participou de outras exposições, em Paris, dentre elas uma individual em Galerie Paul Guillaume, apresentada por Albert C. Barnes, especialista e colecionador que comprou várias de suas pinturas.

Em maio de 1927, teve uma exposição individual na Galerie Jeanne Bucher, em Paris, apresentada por Waldemar George. Roger Vitrac dedicou uma monografia a ele (Giorgio de Chirico et son oeuvre, Editora Gallimard, Paris), analisando os novos temas em suas telas. 
1928

Abre sua primeira exposição individual em Nova York, na Galeria Valentine, em janeiro, e em Londres, no Arthur Tooth and Sons, em outubro. Em fevereiro, mostrou as suas obras neoclássicas na galeria L'Effort Moderne de Lénce Rosenberg. Os surrealistas, por outro lado, organizaram polêmica mostra (Euvre Anciennes de Georges de Chirico, que incluíram algumas das obras metafísicas que, em sua maioria, pertenciam à coleção de Breton). Foram publicadas monografias de Boris Ternovetz (Edizioni Scheiwiller Milan), Waldemar George (Ed. Chroniques du Jour, Paris) e Le Mystère Laic - Essai d'étude índirecte de Jean Cocteau (Edições de Quatre Chemins, Paris) com litografias do artista. Esse documento foi a primeira análise estética profunda de seu trabalho desde as críticas de Apollinaire e Breton. A polêmica com os surrealistas alcançou o topo. Luis Aragon o atacou diretamente na apresentação (Lê feuileton chanfe d"Auteur) da sua exposição individual na Galeria Surrealista em Paris. Pierre Courthion e Carl Einstein também escreveram sobre ele. Outras exposições individuais e coletivas aconteceram em Paris, Bruxelas, Berlim, Moscou. Scheiwiller publicou em Milão o seu Piccolo Trattato Técnica Pittorica. De Chirico deu início a decoração do hall principal no Léonc Rosenberg's (75, Rua de Longchamps) com o ciclo Gladiators, e terminou no início de 1929.

\section{9-1930}

A editora de Pierre Levy, Éditions du Carrefour, publicou Hebdomeros, le peintre et son génie chez l'ecrivain, um texto autobiográfico e uma obra-prima, o seu mais importante trabalho literário. Aragon, até então hostil com o artista, enalteceu a sua magnificência.

De Chirico projetou os cenários e figurinos para o balé Le Bal do Boris Kochno, com música do Vittorio Riete, produzido por Sergej Diaghilev, primeiro em Monte Carlo, e depois em Paris e Londres.

De Chirico se casou com Raissa em 03 de fevereiro.

Gallimard publicou Calligrammes de Guillaume Apollinaire, com sessenta e seis litografias de De Chirico. Exposição coletivas e individuais foram apresentadas em vários países. $\mathrm{O}$ trabalho de De Chirico passou a integrar as coleções dos museus mais importantes.

O seu casamento com Raissa terminou no final de 1930. Deu início a produção da série Mysterious Baths. 


\section{1-1932}

Em sua Memorie, de Chirico registrou o seu encontro com Isabella Far, em 1931, mas Elena Sciltian que apresentara ambos, se recorda que o encontro entre Isabella Pakszwe (posteriormente Isabella Far) e Giorgio de Chirico data de novembro ou dezembro de 1930. Isabella Far se tornou sua segunda esposa; permaneceram juntos até a artista morte do artista.

Participou de várias exposições individuais e de coletivas internacionais (França, Inglaterra, Alemanha, Estados Unidos, Tchecoslováquia). Fez uma exposição individual muito importante em Praga, na Umeleckà Baseda, apresentada por Càrra. Participou de sua primeira exposição individual na América, a famosa Never Super-Realisin, no Wadsworth Atheneum de Hartford.

Em 1932, de Chirico e Isabella Pakszwer se mudaram para Florença. Lá, frequentaram o antiquário Luigi Bellini, que organizou uma exposição individual em sua galeria, no Palazzo Ferroni, em abril. De Chirico na XVIII Bienal de Veneza, na sala dedicada aos italianos de Paris, apresentada pelo Gino Severini. De Chirico continuou viajando, e concentrou a sua exposição na Itália. Além da exposição individual em Florença e da Bienal de Veneza, teve outra exposição individual em Milão (Galleria Milano).

Atuou no teatro, projetando cenários e figurinos para Pulcinella, produzido pela Ópera Russa, em Paris, e para Ariadne et Bacchus, um balé com música de Albert Roussel e coregrafia do Serge Lifar, na Ópera Paris.

\section{3-1934}

Viajou muito entre Gênova, Florença e Turim, mas viveu a maior parte do tempo em Milão (Via Rugabella, 9). Fez uma exposição individual, em 1933, na Galeria II Faro, Turim, onde conheceu Romano Gazzera, descrevendo-o em seu Memorie como um pintor talentoso. Fez uma exposição individual em Gênova (Galleria Vitelli) e em Florença (Palazzo Ferroni). Participou de exposição coletiva em Viena, Chicago, Antuérpia, Paris, Nova York, Amsterdã, Zurique, Bruxelas e Petersburgo. Seu evento mais importante, em 1933, foi ter participado da V Trienal de Milão, para a qual produziu o grande afresco Cultura Italiana, usando a técnica têmpera. Sironi, Campigli, Funi e Severini também participaram dessa iniciativa, organizada pelo primeiro e intitulada L'Italia nelle sue manifestazioni più nobili e varie. De Chirico continuou a sua atividade teatral, produzindo 
cenários e figurino para Il Puritani, de Vincenzo Bellini, dirigido por G. Salvini, para o I Maggio Musicale Fiorentino (1933); e os cenários para La figlia di Jorio, de Gabriele D'Annunzio, dirigida por Pirandello no Teatro Argentina em Roma para o Congresso Internacional de Teatro.

Le Surréalisme au service de la révolution (no. 6, 15 de maio de 1933) publicou as respostas dos surrealistas para o questionário sobre a obra de arte de De Chirico Énigme d'une journée.

Em 1934, de Chirico e Isabella retornaram a Paris. De Chirico estudou tratados antigos sobre técnicas de pintura na Bibliothèque Richelieu. Fez litografias para Mythologie do Cocteau (Editora Des Quatre Chemins, Paris).

\section{5-1937}

Exibiu 45 trabalhos na II Quadriennale d'Arte Nazionale di Roma (Palazzo delle Esposizioni). Houve outras exposições importantes em Lucerna e em Paris.

Em 27 de agosto de 1936, foi para Nova York no navio Rex de Gênova. Nos Estados Unidos, foi convidado de Barnes, em Merion, perto da Filadélfia. Muitos trabalhos foram adquiridos por museus e por Barnes. Isabelle Pakzswer encontrou-se com ele em Nova York (onde moraram até 11 de junho de 1937). Em junho de 1937, a mãe do artista faleceu. Em Nova York, a exposição individual Recent Paintings and Gouaches by de Chirico ocorreu na Galeria Julien Levy. De Chirico participou também da exposição coletiva Fantastic Art, Dada, Surrealism no Museu de Arte Moderna (que depois viajou pelos Estados Unidos). A monografia de Giuseppe Maria Lo Duca, Giorgio De Chirico, foi publicada na Itália com notas bibliográficas de Giovanni Scheiwiller (Hoepli, Milão).

Em 1937, uma exposição importante aconteceu, em Londres, na Galeria Zwemmer. Contribuiu para as revistas Vogue e Harper's Bazaar. Pintou um mural com doze pés para o alfaiate Scheiners de Nova York intitulada Petronio e l'Adone moderno in frack; decorou uma parede para o Instituto de Beleza Helena Rubinstein, e uma sala de jantar para Decorators Pictures Gallery com Picasso e Matisse. Em Roma, em junho de 1937, a Galleria Roma inaugurou uma exposição com participação de De Chirico. Fez, também, uma exposição individual na Galleria della Cometa, em Roma. 


\section{8}

Em janeiro, de Chirico e Isa retornaram à Itália. Depois de alguns dias em Roma, estabeleceram residência em Milão (Via del Gesù). Durante o ano, fizeram breves viagens para Paris e Londres. De Chirico fez exposições em Milão (Galleria Barbaroux, Galleria del Milione), Gênova (Galleria Rotta), Veneza (Galleria Arcobaleno). Houve inúmeros artigos de críticos nos jornais. Carlo Carrà resenhou a exposição Barbaroux (Carlo Carrà, Giorgio de Chirico, L'Ambrosiano, Milão, 16 de março). Fez uma exposição individual importante em Londres: Giorgio de Chirico 1911-1917 (London Gallery), uma exposição monográfica com quatorze obras e quatro desenhos. A London Gallery publicou o texto Mystery and Creation de Giorgio De Chirico em inglês e francês na The London Bulletin no. 6. A edição de novembro de Emporium (Bergamo) com La cosiddetta Arte Metafisica de De Pisis. Edizioni della Cometa of Rome preparou os ensaios da tradução italiana (com correções do Libero De Libero) do Ebdòmero, mas eles não foram publicados.

1939

Mudou-se de Milão para Paris, aborrecido com o tão chamado "decreti per la difesa della razza". Escreveu em suas Memórias: "Decidimos voltar a Paris porque não pretendíamos morar em um país onde todos os sentimentos de humanidade, dignidade, civilização, consciência, decência pareciam ter sido completamente banidos". Expôs na III Quadriennale d'Arte Nazionale di Roma (Palazzo delle Esposizioni), no Museu de Arte Moderna de Boston, na Exposição de Arte Contemporânea Italiana em Nova York. A Milanese Galleria del Milione organizou várias exposições coletivas. Trabalhos das coleções de Broglio e Castelfranco apareceram no mercado em Milão. Fez uma exposição coletiva em Paris no Musée des Arts Décoratifs e uma individual na Galerie des Quatre Chemins, na qual os desenhos para os cenários e figurinos de espetáculos teatrais foram expostos, como Orestes, de Aeschilus, The Bacchae, de Eurípides e The Minotaure, de L. Gautier Vignal. Breton citou-o junto com Savinio na Anthologie de l'Humour Noir.

\section{0-1941}

Morou entre Milão (Via del Gesù) e Florença. Em 1940, trabalhou com algumas esculturas em terracota e criou Archeologi, Ettore e Andromaca, Ippolito e il suo cavallo, assim como Pietà. Os novos trabalhos foram apresentados pela primeira vez na Galleria Barbaroux, em Milan (novembro de 
1940), e então novamente em março de 1941 com algumas esculturas, recebendo algumas críticas. Suas pinturas recentes foram mostradas em duas exposições individuais em Turim e Milão. Um dos seus autorretratos no figurino, Autoritratto em costume oriental, foi exibido na mostra coletiva na Sala d'Arte della Nazione, em Florence (fevereiro de 1940). Publicou Il Signor Dudron em Prospettive (Roma, 15 de maio), e um texto fundamental sobre a escultura Brevis Pro Plastica Oratio em Aria d'Italia.

Em 1941, numa exposição individual importante na Galleria del Milione, em Milão, exibiu trabalhos da coleção de Castelfranco de 1919 a 1926. A Edizioni della Chimera de Milão publicou vinte litografias para L'Apocalisse, revisada por Raffaele Carrieri e comentada por Massimo Bontempelli. The Early Chirico de James Thrall Soby foi publicado em 1941.

\section{2}

Em janeiro, ele participou de uma exposição coletiva: Exhibition Inaugurating the Collection Société Anonyme, na galeria Yale Art em New Haven. Em março, fez uma exposição individual em Nova York, na Galeria Perls. Em junho, participou da XXIII Bienal de Veneza com um número substancial de obras, mal recebidas pelos críticos, exceto por Libero De Libero. Marcel Duchamp publicou a série do Compensation Portraits sobre artistas participantes na exibição First Papers of Surrealism na qual de Chirico foi caricaturado, ironicamente, com um perfil antigo. Preparou os cenários para o balé Anfione baseado no texto de Paul Valéry, com música de Arthur Honnegger e coreografia de Aurel Miloss, apresentado na La Scala di Milan, em 12 de outubro de 1942. De Chirico escreveu inúmeros artigos teóricos para vários periódicos, entre eles Stile - onde, em janeiro, Considerazioni sulla pittura moderna foi publicado, criando muita polêmica e debate - e L'Illustrazione Italiana. Estes artigos foram apresentados na La Commedia dell'arte moderna (Traguardi, Nuove Edizioni Italiane, Roma 1945). L'Illustrazione Italiana também publicou Discorso sulla materia pittorica (26 de abril), Paesaggi (5 de julho), Discorso sullo spettacolo teatrale (25 de outubro). As traduções de Hebdomeros para o inglês e para o italiano foram publicadas. Em 1942, surge a monografia de Raffaele Carrieri: Giorgio de Chirico (Garzanti, Monografie d'Arte di Stile, Milão). Robert Motherwell publicou o seu ensaio Notes on Mondrian \& Chirico. 2. The art of reaction: the late Chirico. 
1943

Em 8 de setembro, deixou Florença e viajou frequentemente entre Roma e Toscana. Exibiu na IV Quadriennale d'Arte Nazionale di Roma. Fez várias exposições individuais em Roma (Galleria Lo Zodiaco), Florença (Galleria Donatello), Veneza (Galleria del Cavallino), e Nova York (Peggy Guggenheim's Art of this Century). As revistas View e $V V V$ em Nova York publicaram estudos críticos sobre o trabalho metafísico de De Chirico. Escreveu um ensaio importante La forma nell'arte e nella natura, publicado na L'Illustrazione Italiana de 21 de março, posteriormente atribuído a Isabella Far.

\section{4-1945}

Fixou residência permanente em Roma (primeiro na Via Gregoriana e depois na Via Mario de' Fiori). Em 1944, de Chirico reduziu suas exposições para quatro exposições em grupo, duas em Milão e duas em Roma. Em 1944, um ensaio importante de Robert Melville sobre De Chirico e Rousseau foi publicado (Rousseau and Chirico, Scottish Art and Letters, Glasgow). Ilustrou a fábula Nel paese della gattafata de Orsola Nemi (Edizioni Documento, Roma); produziu os cenários para o balé Don Giovanni, com música do Richard Strauss e coreografia de Aurel Milloss para a Rome Opera. Hebdomeros foi traduzido para o inglês por P. Bowles na View (Nova York, dezembro de 1944, nos. 3 e 4).

Começou a expor novamente em 1945, com mostras individuais importantes em Roma (Galleria del Secolo and Galleria La Margherita). Seu famoso Autoritratto nudo foi exibida na exposição Galleria del Secolo; foi a versão sem tapa-sexo, depois adicionado para a exposição no Royal Society of British Artists em Londres (Royal Society Academy, maio de 1949). Suas polêmicas com os críticos continuaram a tal ponto que eles não entenderam o significado dos autorretratos com figurinos dos séculos dezesseis e dezessete. Outra exposição importante foi na Galleria San Silvestro de Roma (com Alfredo Biagini) onde algumas paisagens da Villa Médici foram mostradas. As publicações de 1945 incluíram: 1918-1925. Ricordi di Roma (Editora Cultura Moderna, Roma); Memorie della mia vita (Astrolabio, Roma); Commedia dell'arte moderna com Isabella Far (Traguardi, Nuove Edizioni Italiane, Roma). Seu romance Une aventure de Monsieur Dudron foi publicado em Paris. 


\section{6-1947}

Em junho, o artista abriu uma exposição individual na Galerie Allard em Paris. De Chirico anunciou que todos os trabalhos datados de 1919 e 1920 na exposição eram falsos. Este foi o começo da polêmica sobre a autenticidade das suas telas que se agravaria com o passar dos anos. Participou de várias exposições em grupo na Itália (Milão, Roma, Turim, Trieste), e no exterior (Nova York, Paris, Berne, Bruxelas e Buenos Aires) onde trabalhos de seu período metafísico continuaram a ser exibidos. O importante colecionador belga René Gaffé escreveu a monografia Giorgio de Chirico le Voyant (Ed. La Boétie, Bruxelas) que cobria a sua produção desde 1920. Em 18 de julho de 1946, de Chirico casou-se com Isabella Pakzswer.

Durante 1947, mudou o seu estúdio para Piazza di Spagna.

\section{8-1949}

Francesco Arcangeli apresentou a exposição Tre pittori italiani dal 1910 al 1920 (Carrà, de Chirico, Morandi) na XXIV Bienal de Veneza. De Chirico não concordou com a escolha dos trabalhos e anunciou que uma das pinturas da exposição era falsa. No final de 1948, foi nomeado membro da Royal Society of British Artists, e em maio de 1949, fez uma exposição individual com mais de cem trabalhos na Royal Academy of London. Outra exposição individual foi feita em Veneza em 1949 (Salone degli Specchi of Ca' Giustinian), organizada por Giorgio Zamberlan. Os artistas abstratos, encabeçados por Emilio Vedova, reagiram fortemente e tentaram inibir o artista de dar uma conferência. De Chirico produziu os cenários para $L a$ lunga notte di Medea, de Conrado Álvaro, para a companhia de Tatiana Pavlov, e Orfeu, de Monte Verdi para o XII Magro Musica Le Fiorentino. Surge a monografia Il primo de Chirico de Italo Faldi (Ed. Aleire/Sereníssima, Veneza), comentada por Carlo Ludovico em La Critica d'Arte na qual a comparação entre a arquitetura de Chirico e a do século XIX clássica alemã foi proposta. O livro de Massimo Valsecchi, La Metafisica di Giorgio de Chirico (Edizioni del Milione, Milão), foi publicado.

\section{0-1952}

Polemizando com a Bienal de Veneza, organizou uma AntiBienal na Società Canottieri Bucintoro onde pintores antimodernos foram expostos: De Chirico, R. Gazzera, M. De Alzaga, C. Guarienti, V. Freccia, J. Noxon, P. Weiss. Os objetivos desta exposição foram definidos no catálogo, escrito 
por Giorgio de Chirico (Museo degli Orrori. Dichiarazione Biennale a fuoco, Veneza, 23 de setembro de 1950, única edição). A polêmica continuou em exposições individuais no mesmo local em 1952 e 1954. Outras exposições individuais aconteceram em Gênova, Nápoles, Roma, Como e Milão, na Galleria Gian Ferrari, onde ele apresentou uma série de pinturas dos séculos XV e XVI com molduras ostentosas, dependurandoas em paredes de tapeçaria vermelhas. Continuou sua atividade cenográfica. Em 1950, escreveu uma série de artigos, para a parte mais antimodernista para Il Giornale d'Italia.

Em 1951, produziu cenários e figurinos para Ifigênia de Ildebrando Pizzetti na XIV Maggio Musicale Fiorentino; para La Leggenda di Giuseppe na La Scala; para Don Chisciotte do V. Frazzi no XV Maggio Musicale Fiorentino; para Mefistofele na Scala.

Em 5 de maio de 1952, Alberto Sivinio morreu de ataque cardíaco em Roma. Desde então Giorgio de Chirico passou a usar uma gravata preta em sinal de luto.

Uma exposição coletiva, Twentieth-Century Masterpieces, foi apresentada em Londres, na Tate Gallery, de 15 de julho a 17 de agosto.

\section{3-1959}

Giorgio de Chirico fez exposições individuais importantes em Turim (1953 e 1958), Roma (1952 e 1958), Veneza (1954, 1955 e 1959), Houston (1955), Nápoles (1955), Florença (1955 e 1958), Milão (1953, 1955 e 1958), Nova York (1955, no MoMA). A exposição do MoMA mostrou vinte trabalhos metafísicos do artista. Exposições coletivas aconteceram em Bruxelas, Turim, Wakefield, Minenápoles, Bari, Barcelona, Houston, Nova York, São Francisco, Roma (VII Quadrienal, 1955, e VIII Quadrienal, 1959), Kassel (Documenta I, 1955), Nápoles, Perth, Veneza (XXVIII Bienal, 1956), Londres, Chicago, Toronto, Munique, Tunis. De Chirico continuou a polemizar a pintura moderna, escrevendo para várias revistas e também participando em programas de televisão. Trabalhou como cenógrafo para La coda santa, de D. Terra, no Teatro dei Satiri de Roma (1953) e para Apollon Musagète, de Igor Stravinskij, na Piccola Scala de Milão (1956). Em 1953,foi publicada a monografia Isabella Far (Ediozioni Bestetti, Roma; então, Fratelli Fabbri Editori, Milão 1966). 


\section{0-1969}

De Chirico continuou trabalhando com temas de seu gosto, reelaborando-os com suaves variações. O seu trabalho foi bem recebido pelo público e pelo mercado. Suas exposições individuais nestes anos foram numerosas, na Itália e no exterior.

Em 1964, de Chirico voltou para o teatro, desenhando cenários para as produções Rome Opera de Otello. Em 1969, 194 Disegni di Giorgio de Chirico, editado por Ezio Gribaudo (Edizioni d'Arte Fratelli Pozzo, Turim), e Giorgio de Chirico, Catalogo delle opere grafiche 1921-1969 de Alfredo Ciranna e Cesare Vivaldi (Edizioni La Medusa, Milão/ Roma) foram publicados. Escreveu vários artigos para a revista "Candido" de Milão. Em 1962, Memorie della mia vita foi publicado (Rizzoli, Milão). Ele ilustrou I Promessi Sposi (1965), a Iliade (1968), e Auf der Galerie de Franz Kafka (Ghottard de Beauclair, Frankfurt 1969).

Em 1966-1968 teve início o período neometafísico, que fez releituras de toda a experiência metafísica.

No final da década de 1960, fez versões de esculturas em bronze, reproduzindo os protagonistas de sua imaginação metafísica e seus cavalos clássicos. $\mathrm{O}$ artista também produziu múltiplos em bronze com prata ou dourado e jóias em prata e prata dourada.

\section{0-1978}

Em 1970, uma exposição das esculturas de De Chirico foi exibida na Galleria La Medusa em Roma. De abril a maio de 1970, importante exposição antológica de De Chirico foi apresentada no Palazzo Reale em Milão (e em Hanover em julho e agosto). O catálogo foi feito por Wieland Schmied; a exposição mostrou toda a produção artística dele. Outra exposição individual importante foi apresentada em Ferrara, em 1970, Il De Chirico de De Chirico, na Galleria Cívica d'Arte Moderna (Palazzo dei Diamanti). Em 1970, de Chirico publicou Ego Sum Pictor Optimus na Bolaffi Arte.

Em 1971, houve várias exposições importantes, em particular: na Galleria Schuber de Milão, na Galleria Medea de Milão e na Galleria La Medusa de Roma. Em 1971, Electa publicou os oito volumes do Catalogo Generale di Giorgio de Chirico revisado por Cláudio Bruni Sakraischik.

Em 1972, ele recebeu o Premio Ibico Reggino pela primeira vez (Henry Moore recebeu para escultura), estabelecido por Virgilio Guzzi na ocasião da sua primeira exposição individual Omaggio a Giorgio de Chirico, no Museo Nazionale of Reggio Calábria. Outras exposições importantes foram apresentadas em Nova 
York (no Centro Cultural Nova York), Toronto, Veneza (XXXVI Bienal), Roma (X Quadrienal). Em 1972, de Chirico fez as ilustrações para o seu romance Ebdòmero (Bestetti, Roma).

Em 1973, uma exposição itinerante pelo Japão (Tóquio, Kioto e Nagoya) foi organizada. Ele mostrou a sua famosa fonte, Bagni Misteriosi, na exposição Contatto Arte/Città para a XV Trienal de Milão no Parque do Palazzo della Triennale. Em 1974, foi nomeado pela Académie Française. Suas exposições continuaram na Itália e no exterior. Em 1975, se tornou membro da Académie Française. Naquela ocasião, uma importante exposição antológica foi apresentada no Musée Marmottan em Paris. Em 1976, recebeu o Cruzeiro do Grand Officer da República da Alemanha. Em 1977, participou de exposições coletivas no Museum des XX Jarhunderts, em Viena, no Centro George Pompidou em Paris e na Schloss Charlottenburg em Berlim. Em 1978, a celebração foi no Campidoglio em Roma para o aniversário de noventa anos do artista. Na França, o aniversário de noventa anos do artista foi celebrado com uma exposição, promovida por Isabella Far, no Artcurial em Paris, e com a publicação do volume De Chirico par de Chirico (Damase, Paris). Em 20 de novembro de 1978, Giorgio de Chirico morreu em Roma, depois de um longo período internado em uma clínica. O seu túmulo está em San Francesco a Ripa, em Roma, desde 1991.

Em 1986, a Fundação Giorgio e Isa de Chirico foi inaugurada em Roma, tendo como presidente Isabella Far, e vice-presidente Cláudio Bruni Sakraischik. O seu objetivo: proteger a personalidade intelectual e artística de Giorgio de Chirico. Em 19 de novembro de 1990, Isabella Far faleceu em Roma. A Fundação Giorgio e Isabella de Chirico foi apontada como herdeira dos bens do artista, incluindo sua casa e a maioria de suas obras de arte.

Em 1998, no vigésimo aniversário da morte de De Chirico, foi inaugurada em Roma, na casa de De Chirico na Piazza di Spagna, a Casa Museu Giorgio de Chirico.

Fonte: www.fundacaoisaegiorgiodechirico.it. 